Florida International University FIU Digital Commons

\title{
A Generation of Race and Nationalism: Thomas Dixon, Jr. and American Identity
}

Tiffany West

Florida International University, twest007@fiu.edu

DOI: $10.25148 /$ etd.FIDC000743

Follow this and additional works at: https://digitalcommons.fiu.edu/etd

\section{Recommended Citation}

West, Tiffany, "A Generation of Race and Nationalism: Thomas Dixon, Jr. and American Identity" (2016). FIU Electronic Theses and Dissertations. 2579.

https://digitalcommons.fiu.edu/etd/2579

This work is brought to you for free and open access by the University Graduate School at FIU Digital Commons. It has been accepted for inclusion in FIU Electronic Theses and Dissertations by an authorized administrator of FIU Digital Commons. For more information, please contact dcc@fiu.edu. 


\section{FLORIDA INTERNATIONAL UNIVERSITY}

Miami, Florida

A GENERATION OF RACE AND NATIONALISM: THOMAS DIXON, JR. AND AMERICAN IDENTITY

A dissertation submitted in partial fulfillment

of the requirements for the degree of

DOCTOR OF PHILOSOPHY

in

HISTORY

by

Tiffany West

2016 
To: Dean John F. Stack, Jr.

Green School of International and Public Affairs

This dissertation, written by Tiffany West, and entitled A Generation of Race and Nationalism: Thomas Dixon, Jr. and American Identity, having been approved in respect to style and intellectual content, is referred to you for judgment.

We have read this dissertation and recommend that it be approved.

April Merleaux

Kirsten Wood

Erik Larson

Professor Darden A. Pyron, Major Professor

Date of Defense: July 8, 2016

The dissertation of Tiffany West is approved.

Dean John F. Stack, Jr. Green School of International and Public Affairs

Andrés G. Gil

Vice President for Research and Economic Development and Dean of the University Graduate School

Florida International University, 2016 
ABSTRACT OF THE DISSERTATION

A GENERATION OF RACE AND NATIONALISM: THOMAS DIXON, JR. AND AMERICAN IDENTITY

by

Tiffany West

Florida International University, 2016

Miami, Florida

Professor Darden A. Pyron, Major Professor

Thomas Dixon (1864-1946) has won a singular place in history as a racial ideologue and an exemplar of Southern racism. The historical evidence, however, suggests Southern culture was only one of a variety of intellectual influences, and, though highly visible in most famous works, not Dixon's primary concern. Rather, his discussions of the South are framed within larger intellectual debates over the region as a whole, and how it related to the rest of the nation. Throughout his life, Dixon helped shape and articulate those values in the formation of a new American identity at the turnof-the-century. By incorporating the methods of intellectual biography, whiteness studies, literary analysis, and cultural studies into the scholarly approaches of history, this work enlarges the historical understanding of Dixon through the examination of his very long life and varied career and the exploration of his equally diverse and numerous writings, both personal and public. This project's end goal is to enrich historical understanding of how national identity is interpreted, constructed, and shaped over time, and the many different components influencing its formation. 
This research found that defining what is and is not American built on and responded to the major issues of a specific historical context. Dixon's, and the nation's larger attempts at defining the terms of Americanism became increasingly complicated during key national turning points, such as the Spanish-American War, the economic depressions of the $1890 \mathrm{~s}$, and political realignments at the turn-of-the-century. Analyzing Dixon's works revealed the influence of the various forces that reshaped American identity, including race theories, scientific advancements, immigration, sectional reconciliation, imperialism, and religion. This work concludes that national identity construction is fluid, and that researchers must consider the importance of historical context in analyses of ideology and cultural trends. 


\section{TABLE OF CONTENTS}

CHAPTER

PAGE

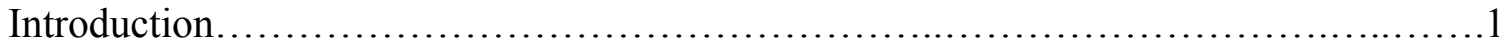

Chapter One

A Political Education in Theory and Practice (1879-1886) 12

Chapter Two

No Difference Between Secular and Divine (1886-1895).....................58

Chapter Three

The Emergence of White Nationalism in Dixon's Public Works (1896-1901)...100

Chapter Four

The Reconstruction Trilogy (1902-1907)................................139

Chapter Five

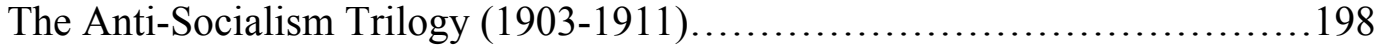

Chapter Six

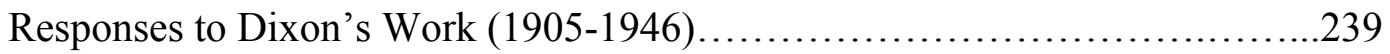

Epilogue...............................................................273

Bibliography...........................................................276

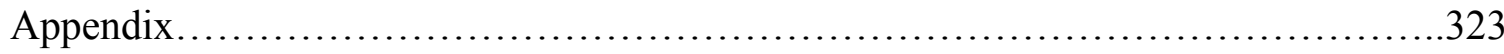

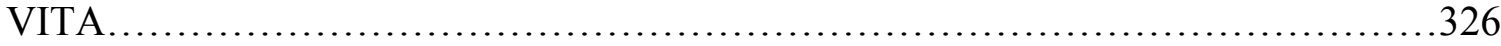




\section{$\underline{\text { Introduction }}$}

"Morals are relative things. They are based on the experiences and faiths of the generations which express them."-Comrades (1909)

Thomas Dixon, Jr. has become ubiquitous in the numerous academic discussions of white supremacism at the turn of the century. He has won a singular place in history by his creation of a trilogy of novels set during Reconstruction, The Leopard's Spots, The Clansman, and The Traitor, which he published between 1902 and 1907. The film adaptation of these fictions, D.W. Griffith's silent epic, Birth of a Nation (1915) brought Dixon even greater fame and notoriety. ${ }^{1}$ For the century since, Dixon's public standing, based on the trilogy and film, has revolved around his reputation as a racial ideologue and

\footnotetext{
${ }^{1}$ The Birth of a Nation, the 1915 silent epic film directed by D.W. Griffith, has received extensive historical attention in the fields of American culture, race relations, and film studies. It is notable not only for its content, but its style and filming techniques. A multitude of scholars study the film. See: John Hope Franklin, "'Birth of a Nation': Propaganda as History," The Massachusetts Review 20, no. 3 (Autumn 1979): 417-434; Brian Gallagher, "Racist Ideology and Black Abnormality in The Birth of a Nation," Phylon 43, no. 1 ( $1^{\text {st }}$ Quarter 1982): 68-76; Everett Carter, "Cultural History Written With Lightning: The Significance of The Birth of a Nation (1915)," in Hollywood as Historian: American Film in a Cultural Context (Lexington: University Press of Kentucky, 1983) edited by Peter C. Rollins; Michael Paul Rogin, "'The Sword Became a Flashing Vision': D.W. Griffith's The Birth of a Nation," in Ronald Reagan The Movie: And Other Episodes in Political Demonology (Berkeley: University of California Press, 1987): 190235; Jeffrey B. Martin, "Film Out of Theatre: D.W. Griffith, Birth of a Nation and the Melodrama The Clansman," Literature/Film Quarterly 18, no. 2 (1990): 87-95; Robert Lang, ed., The Birth of a Nation (New Brunswick: Rutgers University Press, 1994); Amy Kaplan, "The Birth of an Empire," PMLA 114, no. 5 (October 1999): 1068-1079; Riché Richardson, "'The Birth of a Nation'hood': Lessons from Thomas Dixon and D.W. Griffith to William Bradford Huie and The Klansman, O.J. Simpson's First Movie," The Mississippi Quarterly 56, no. 1 (Winter 2002/2003): 3-31; Michele Faith Wallace, "The Good Lynching and 'The Birth of a Nation': Discourses and Aesthetics of Jim Crow," Cinema Journal 43, no. 1 (Autumn 2003): 85-104; Melvyn Stokes, D.W. Griffith's The Birth of a Nation: A History of "the Most Controversial Motion Picture of All Time" (New York: Oxford University Press, 2007); Riché Richardson, "Lesson from Thomas Dixon to The Klansman," in Black Masculinity and the U.S. South: From Uncle Tom to Gangsta (Athens: University of Georgia Press, 2007), 24-72; and Eric Olund, "Geography Written in Lightning: Race, Sexuality, and Regulatory Aesthetics in The Birth of a Nation," Annals of the Association of American Geographers 103, no. 4 (2013): 925-943.
} 
an exemplar of Southern racism. Most of the Dixon historiography focuses on the

novels' and film's racial imagery and promotion of white supremacy; these elements are

often credited with helping to fuse white supremacist attitudes into large swaths of the

American public, and sparking the early-twentieth century rebirth of the Ku Klux Klan. ${ }^{2}$

While some recent works have attempted to further explore the historical context

surrounding Dixon's work, no singular historical work has explored his ideological

${ }^{2}$ The most comprehensive biographies covering Thomas Dixon, Jr.'s entire life were written by Raymond Allen Cook, Fire From the Flint: The Amazing Careers of Thomas Dixon (Winston-Salem, North Carolina: John F. Blair, 1968) and Thomas Dixon (New York: Twayne Publishers, Inc., 1974). For more on the life and works of Dixon, see: Max F. Harris, "Ideas of Thomas Dixon on Race Relations," (MA Thesis, University of North Carolina, 1948); Frances Oakes, "Whitman and Dixon: A Strange Case of Borrowing," The Georgia Review 11, no. 3 (Fall 1957): 333-340; Thomas L. Gross, "The Negro in the Literature of Reconstruction," Phylon 22, no. 1 (1961): 5-14; Maxwell Bloomfield, "The Leopard's Spots: A Study in Popular Racism,” American Quarterly 16, no. 3 (Autumn 1964): 387-401; James Zebulon Wright, "Thomas Dixon: Mind of a Southern Apologist," (MA Thesis, The George Peabody School for Teachers, 1966); F. Garvin Davenport, Jr., "Thomas Dixon's Mythology of Southern History," Journal of Southern History 36, no. 3 (August 1970): 350-367; Russell Merritt, "Dixon, Griffith, and Southern Legend," Cinema Journal 12, no. 1 (Autumn 1972): 26-45.; David K. Clerico, "Thomas Dixon, Jr. and the Trilogy of Reconstruction," (MA Thesis, Southwest Texas State University, May 1974); Samuel K. Roberts, "Kelly Miller and Thomas Dixon, Jr. on Blacks in American Civilization," Phylon 41 ( $2^{\text {nd }}$ Quarter 1980): 202-209; James Kinney, "The Rhetoric of Racism: Thomas Dixon and the 'Damned Black Beast'," American Literary Realism, 1870-1910 15, no. 2 (Autumn 1982): 145-154; Williamson, The Crucible of Race (1984); Lawrence J. Oliver, "Writing from the Right during the 'Red Decade': Thomas Dixon's Attack on W.E.B. DuBois and James Weldon Johnson in The Flaming Sword," American Literature 70, no. 1 (March 1998): 131-152; Kim Magowan, "Coming Between the 'Black Beast' and the White Virgin: The Pressures of Liminality in Thomas Dixon," Studies in American Fiction 27, no. 1 (Spring 1999): 77-102; Brian R. McGee, "Thomas Dixon's The Clansman: Radical, Reactionaries, and the Anticipated Utopia." Southern Communications Journal 65, no. 4 (Summer 2000): 300-317; Scott Romine, "Things Falling Apart: The Postcolonial Condition of Red Rock and The Leopard's Spots," in Look Away! The U.S. South in New World Studies, edited by Jon Smith and Deborah Cohn (Durham: Duke University Press, 2004): 175-200; Chris Ruiz-Velasco, "Order Out of Chaos: Whiteness, White Supremacy, and Thomas Dixon, Jr.," College Literature 34, no. 4 (Fall 2007): 148-165; Harilaos Stecopoulos, "The Geography of Reunion: Thomas Dixon, Charles Chesnutt, and the McKinley Expansionists," in Reconstructing the World: Southern Fictions and U.S. Imperialisms, 1898-1976 (Ithaca: Cornell University Press, 2008), 1-17; Peter Schmidt, "Educating Whites to Be White on the Global Frontier: Hypnotism and Ambivalence in Thomas Dixon and Owen Wister, 1900-1905," in Sitting in Darkness: New South Fiction, Education, and the Rise of Jim Crow Colonialism, 1865-1920 (Oxford: University Press of Mississippi, 2008), 151-173; Brook Thomas, "The Clansman's Race-Based Anti-Imperialist Imperialism," The Mississippi Quarterly 62, no. 1/2 (Winter 2009): 303-333; Akiyo Ito Okuda, “'A Nation is Born': Thomas Dixon's Vision of White Nationhood and His Northern Supporters," The Journal of American Culture 32, no. 3 (September 2009): 214-231; Christopher Capozzola, "Thomas Dixon's War Prayers," Journal of Transnational American Studies 1, no. 1 (2009): 61-65; Tara Bynum, “'One Important Witness': Remembering Lydia Brown in Thomas Dixon's The Clansman," Texas Studies in Literature and Language 52, no. 3 (Fall 2010): 247-265; Diana Rebekkah Paulin, "Staging the Unspoken Terror," in Imperfect Unions: Staging Miscegenation in U.S. Drama and Fiction (Minneapolis: University of Minnesota Press, 2012), 99-140. 
development since the biographies of Raymond Allen Cook published decades ago. ${ }^{3}$

This persistent absence of long-term historical context ignores Dixon's long-term themes, often obscuring the critical sources of his racial ideas and their connection to larger historical trends and the emerging patterns of American nationalism. Especially in regard to his position on racial issues, the absence of historical context misconstrues what he intended for American life in his works by presenting him as a Southern-minded ideologue.

Although historical works identified Dixon inseparably with the region of his birth, this work challenges that assumption. The evidence suggests Southern culture was only one of a variety of intellectual influences, and, though highly visible in his most famous works, not Dixon's primary concern. Rather, Dixon's discussions of the South and of race were framed by intellectual debates over the future of the nation's citizenry. His intellectual life rotated not on regional values but on the axis of American identity, national politics, and civic purpose in general. Throughout his adult life, Dixon's main concern remained the construction of a singular, patriotic national identity.

\footnotetext{
${ }^{3}$ A handful of more recent work, in particular, includes excellent discussions of the broader themes in Dixon's work and the influence of historical context. Brook Thomas does a wonderful job placing Dixon's Reconstruction novels within a literary debate over the meaning of citizenship in "The Legal and Literary Complexities of U.S. Citizenship Around 1900," Law and Literature 22 (Summer 2010): 307-324, and in analyzing the pre-World War I socio-political atmosphere of Dixon's lesser-known Lincoln novel in "Thomas Dixon's A Man of the People: How Lincoln Saved the Union by Cracking Down on Civil Liberties," Law and Literature 20, no. 1 (Spring 2008): 21-48; Michele K. and Randal L. Hall, eds., Thomas Dixon, Jr. and the Birth of Modern America (Baton Rouge: Louisiana State University Press, 2006) includes essays on Dixon's ideological influences, but, as an edited collection, offers several different arguments that could be further explored. Anthony Slide's 2004 work, American Racist: The Life and Films of Thomas Dixon (Lexington: University of Kentucky Press, 2004) contains the most comprehensive analysis of the many themes in Dixon's novels, plays, and film, since the work of Cook, but does not begin its narrative until after 1900. The last work, that of Karen Ransom Crowe, is perhaps the best all-around look at Dixon. Crowe compiled different parts of Dixon's unfinished biography into a singular publication, and her introduction to this work does a fantastic job of discussing Dixon's nationalism and the importance of context. See Karen Ransom Crowe, "Introduction," in Thomas Dixon, Southern Horizons: The Autobiography of Thomas Dixon (Alexandria: IWV Publishing, 1982), xv-xxvi.
} 
Dixon subscribed to the idea of "patriotic millennialism," or the belief that God preordained the United States to prosper as a global symbol of Christian civilization and democracy. ${ }^{4}$ He believed that divine will indicated the United States would become a global power in the new, modern age, but that forming a unified patriotic identity was a crucial element for fulfilling this divine prophecy of national prosperity and progress. For him, the "magnificent destiny" of the nation "to lead the hosts of freedom and truth in the last pitched battle with the wrongs, traditions, superstitions, lies, and inequities of the Old World," could only be reached through the development of a "more vigorous Americanism." To Dixon, it seemed that once this new national identity came to fruition, America "would lead the march of the new civilization of the twentieth century.",

During his early adult life, Dixon argued that these socio-economic and political problems complicated the formation of a singular nationalism, thus preventing the nation from obtaining its divinely ordained place as a global leader. Solving racial and classbased tensions, eliminating government corruption, advancing Protestant morality in U.S. politics, and ending sectionalism became his particular concerns. His ideology was driven by a desire to "solve" these problems by spreading his message through a variety of forms and means. Of equal importance, the cultural crises and intellectual innovations of Dixon's own age shaped his worldview. As Dixon worked on new definitions of citizenship, identity, and national purpose after 1880, the nation was fighting the same

\footnotetext{
${ }^{4}$ Joe Creech coined the term "patriotic millennialism" in Righteous Indignation: Religion and the Populist Revolution (Chicago: University of Illinois Press, 2006), 28. For more information on turn-of-the-century religious interpretations of national destiny, see: Conrad Cherry, God's New Israel: Religious Interpretations of American Destiny (Chapel Hill: University of North Carolina Press, 1998); and Richard Allen Landes, Heaven on Earth: The Varieties of the Millennial Experience (New York: Oxford University Press, 2011).

5 “The Need of a More Vigorous Americanism," The Progressive Farmer, April 21, 1891.
} 
battle. $^{6}$ In the process, it witnessed the transformation of politics, society, and culture that continue to shape the United States. Rapid industrialization and urbanization, internal and external migrations, involvement in foreign territory, as well as intellectual developments in religion and science launched debates about the fundamental purpose of the republic and the meaning of citizenship. Indeed, during Dixon's lifetime, the nation redefined what it meant to be "American." Issues of race, gender, sexuality, collective

\footnotetext{
${ }^{6}$ For more information regarding the mid-to-late nineteenth century debate over citizenship, race, and equality, see: Sharon D. Kennedy-Nolle, Writing Reconstruction: Race, Gender, and Citizenship in the Postwar South (Chapel Hill: University of North Carolina Press, 2015); Laura F. Edwards, A Legal History of the Civil War and Reconstruction: A Nation of Rights (Cambridge: Cambridge University Press, 2015); (Bruce E. Baker and Brian Kelly, eds., After Slavery: Race, Labor, and Citizenship in the Reconstruction South (Gainesville: University Press of Florida, 2013); Carole Emberton, Beyond Redemption, Race, Violence, and the American South after the Civil War (Chicago: University of Chicago Press, 2013); Stephen Kantrowitz, More Than Freedom: Fighting for Black Citizenship in a White Republic, 1829-1889 (New York: Penguin, 2012); Faye E. Dudden, Fighting Chance: The Struggle over Woman Suffrage and Black Suffrage in Reconstruction America (New York: Oxford University Press, 2011); Hugh Davis, "We Will Be Satisfied With Nothing Less": The African American Struggle for Equal Rights in the North During Reconstruction (Ithaca: Cornell University Press, 2011); Elizabeth Reilly, ed., Infinite Hope and Disappointment: The Story of the First Interpreters of the Fourteenth Amendment (Akron: University of Akron Press, 2011); Kate Masur, An Example for All the Land: Emancipation and the Struggle over Equality in Washington, D.C. (Chapel Hill: University of North Carolina Press, 2010); Hannah Rosen, Terror in the Heart of Freedom: Citizenship, Sexual Violence, and the Meaning of Race in the Postemancipation South (Chapel Hill: University of North Carolina Press, 2009); Mitchell Snay, Fenians, Freedman, and Southern Whites: Race and Nationality in the Era of Reconstruction (Baton Rouge: Louisiana State University Press, 2007); Charles W. Calhoun, Conceiving a New Republic: The Republican Party and the Southern Question, 1869-1900 (Lawrence: University Press of Kansas, 2006); Joseph A. Ranney, In the Wake of Slavery: Civil War, Civil Rights, and the Reconstruction of Southern Law (Westport: Praeger, 2006); Carol A. Horton, Race and the Making of American Liberalism (New York: Oxford University Press, 2005); Thomas Adams Upchurch, Legislating Racism: The Billion Dollar Congress and the Birth of Jim Crow (Lexington: University Press of Kentucky, 2004); Heather Cox Richardson, The Death of Reconstruction: Race, Labor, and Politics in the Post-Civil War North, 18651901 (Cambridge: Harvard University Press, 2002); Jane Dailey, Glenda Elizabeth Gilmore, and Bryant Simone, eds., Jumpin' Jim Crow: Southern Politics from Civil War to Civil Rights (Princeton: Princeton University Press, 2000); Alexander Keyssar, The Right to Vote: The Contested History of Democracy in the United States (New York: Basic Books, 2000); Kevin Mattson, Creating a Democratic Public: The Struggle for Urban Participatory Democracy During the Progressive Era (Philadelphia: Pennsylvania State University Press,1998); Eric Foner, Nothing But Freedom: Emancipation and Its Legacy (Baton Rouge: Louisiana State University Press, 1993); Earl M. Maltz, Civil Rights, The Constitution, and Congress, 1863-1869 (Lawrence: University Press of Kansas, 1990); Williamson, The Crucible of Race (1984); Lawrence Grossman, The Democratic Party and the Negro: Northern and National Politics, 18681892 (Urbana: University of Illinois Press, 1976); William Gillette: Right to Vote: Politics and the Passage of the Fifteenth Amendment (Baltimore: Johns Hopkins University Press, 1965); and James M. McPherson, The Struggle for Equality: Abolitionists and the Negro in the Civil War and Reconstruction (Princeton: Princeton University Press, 1965).
} 
memory, and morality were intertwined with redefinitions of nationhood and citizenship. ${ }^{7}$

Dixon's works responded and contributed directly to debates about solving the socio-

economic problems resulting from rapid urbanization and industrialization in the late-

nineteenth century; the emergence of science as a new mode of thought; the relation of

science to religion; the place of religion in a democracy; the redefinition of nationalism,

the emergence of post-sectional patriotism; the significance of partisan politics; the

necessity of political reform; the meaning of race and racial values in the national order;

and the redefinition of American values in a global—or imperial—context.

\footnotetext{
${ }^{7}$ Further references about the complex processes that contribute to the development of American identity and patriotism in this period may be found in: Walter Benn Michaels, "Race into Culture: A Critical Genealogy of Cultural Identity," Critical Inquiry 18, no. 4 (Summer 1992): 655-685; Wilfred M. McClay, The Masterless: Self and Society in Modern America. (Chapel Hill: University of North Carolina Press, 1994); Priscilla Wald, Constituting Americans: Cultural Anxiety and Narrative Form (Durham: Duke University Press, 1995); Rogers Smith, Civic Ideals: Conflicting Visions of Citizenship in U.S. History (New Haven: Yale University Press, 1997); Eric Foner, "Who is An American? The Imagined Community in American History," The Centennial Review 41, no. 3 (Fall 1997): 425-438; Reynolds J. Scott-Childress, Race and the Production of Modern American Nationalism (New York: Garland, 1999); Desmond King, Making Americans: Immigration, Race, and the Origins of Diverse Democracy (Cambridge: Harvard University Press, 2000); Gary Gerstle, American Crucible: Race and Nation in the Twentieth Century (Princeton: Princeton University Press, 2001); James E. Block, A Nation of Agents: The American Path to a Modern Self and Society (Cambridge: Belknap Press of Harvard University Press, 2002); Edward J. Blum, Reforging the White Republic: Race, Religion, and American Nationalism, 1865-1898 (Baton Rouge: Louisiana State University Press, 2005); Francesca Morgan, Women and Patriotism in Jim Crow America (Chapel Hill: University of North Carolina Press, 2005); John D. Cox, Traveling South: Travel Narratives and the Construction of American Identity (Athens: University of Georgia Press, 2005); Stephen Skowronek, "The Reassociation of Ideas and Purpose: Racism, Liberalism, and the American political Tradition," The American Political Science Review 100, no. 3 (August 2006): 385-401; Christopher Capozzola, Uncle Sam Wants You: World War I and the Making of the Modern American Citizen (New York: Oxford University Press, 2008); Leigh Anne Duck, The Nation's Region: Southern Modernism, Segregation, and U.S. Nationalism (Athens: University of Georgia Press, 2009); Christina A. ZieglerMcPherson, Americanization in the States: Immigrant Social Welfare Policy, Citizenship, and National Identity in the United States, 1908-1929 (Gainesville: University Press of Florida, 2009); Jennifer Rae Greeson, Our South: Geographic Fantasy and the Rise of National Literature (Cambridge: Harvard University Press, 2010); Arthur Remillard, Civil Religions: Imagining the Good Society in the PostReconstruction Era (Athens: University of Georgia Press, 2011); Michael Kazin and Joseph A. McCartin, eds., Americanism: New Perspectives on the History of an Ideal (Chapel Hill: University of North Carolina Press, 2012); Glenda Elizabeth Gilmore and Thomas J. Sugrue, These United States: A Nation in the Making, 1890 to the Present (New York: W.W. Norton \& Company, 2015); and Leon Fink, The Long Gilded Age: American Capitalism and the Lesson of a New World Order (Philadelphia: University of Pennsylvania Press, 2015).
} 
This dissertation offers a closer study of Dixon's life and works, chronicling his ideological formation from his college years until the first decades of the twentieth century. In doing so, it reflects this reciprocity between the individual and the historical context, demonstrates the prevalence of debates about citizenship, nationalism, the "problems" of modernity in the period's politics, and illuminates how changing social, intellectual, and economic circumstances contributed to these debates. His life and works highlight the major issues in national life during the late-nineteenth and early-twentieth centuries. Each chapter traces Dixon's major ideological developments in a given stage of his life and relates these changes and the major historical events and debates of the period. This project's goal is to enrich historical understanding of how national identity has been shaped over time, and to analyze the many different components influencing its formation.

At different points throughout his life, Dixon offered different means to remedy these issues, and his shifts illuminate the reciprocity between his individual life and the historical context. He provides a unique opportunity to explore the reciprocity between the individual and his times because he intended everything he wrote to shape public opinion throughout a long and varied career. He produced politically engaged writings until 1939, leaving a plethora of source material on a myriad of topics in the historical record. Appropriately, he called himself a "fisherman of men, and if they don't bite with one kind of bait I'll catch them with another." ${ }^{\prime 8}$ In each of his many career ventures, he

\footnotetext{
8 “The Rev. Thomas Dixon on 'Intellectual and Social Aspect of Church Work'," Chicago Daily Tribune, February 11, 1891.
} 
aimed "not to echo public sentiment, but to create it." If one venue proved ineffective, Dixon moved on to another. He recognized the power of different forms of media and current trends in shaping an audience's thoughts, actively employing newspapers, lecture halls, novels, theatre, and film to convey his messages. Fiction, Dixon argued at the turnof-the-century, possessed "great power...as a vehicle for reaching the people with a message or thought." ${ }^{10}$ Declining numbers of readers, though, left writers with "the problem of how to reach the great mass of people with a book." ${ }^{\text {11 }}$ By 1910, Dixon believed that theater was replacing fiction as "the mightiest force of human expression;" it would prove, he thought, to be "the great force... [to] sway the thought and destiny of the nation." "One hundred years from now," he prophesized, "the men who will sway the country will be those who can express themselves in this form." ${ }^{12}$ He did not have to wait. The Birth of a Nation (1915) was one of a series of films in the early-twentieth century that permanently marked popular notions of Civil War and Reconstruction history. ${ }^{13}$ He was far from alone in identifying public opinion as an effective tool of

\footnotetext{
9 "Pulpit Voices: Religious Thought and Progress in the United States," Los Angeles Times, October 31, 1897.

10 “Thos. Dixon to Woman's Club: Tells How To Get a Message to People," The Raleigh Times (Raleigh, North Carolina), October 26, 1906.

${ }^{11}$ Ibid.

12 “Drama Will Sway Nation's Destiny,” The Atlanta Constitution, November 19, 1910.

${ }^{13}$ Scholarly treatments of the role of film and theatre in shaping the collective memory of the Civil War include: Jenny Barrett, Shooting the Civil War: Cinema, History, and American National Identity (New York: I.B. Tauris, 2009); Tavia Amolo Ochieng' Nyongó,The Amalgamation Waltz: Race, Performance and the Ruses of Memory (Minneapolis: University of Minnesota Press, 2009); Gary W. Gallagher, Causes Won, Lost, and Forgotten: How Hollywood and Popular Art Shape What We Known About the Civil War (Chapel Hill: University of North Carolina Press, 2008); Linda Joyce Brown,The Literature of Immigration and Racial Formation: Becoming White, Becoming Other, Becoming American in the Late Progressive Era (New York: Routledge, 2004); S.E. Wilmer, Theatre, Society, and the Nation: Staging American Identities
} 
change; his works were part of a broader emerging trend recognizing the power of media in shaping political outcomes. ${ }^{14}$ He was one voice in a cacophony of suggestions during the late-nineteenth and early-twentieth centuries.

This dissertation combines the methodologies of cultural history, intellectual biography, memory studies, and literary analysis to examine Dixon's life and works. Besides treating his published memoirs, this work makes extensive use of newspaper reports covering his sermons, lectures, business ventures, opinions, and public appearances. It also draws heavily from the extensive study and interpretation of Dixon's novels, published from 1902 to 1939 , collections of sermons and religious pamphlets published in the 1890s, theatrical scripts, and his films. There are several methodological challenges to studying a figure such as Dixon, or any individual, for that matter. Despite the plethora of material he published, including eighteen novels, four nonfiction tracts, numerous plays, an autobiography, and screenplays, Dixon's thought processes are difficult to pin down. Though a talented self-plagiarizer, some of his ideas are not always consistent and even contradictory. Dixon designed each of his public works with an intended, purposeful message, further complicating their analysis with moral, social, and political bias. His estate compounded these difficulties. After his death in 1946, Dixon's second wife, actress Madelyn Clare Dixon (1894-1975) limited access to her husband's

(New York: Cambridge University Press, 2002); and Bruce Chadwick, The Reel Civil War: Mythmaking in American Film (New York: Alfred A. Knopf, 2001).

${ }^{14}$ For some examples of different forms of media and their contribution to American life, see Jonathan Auerbach, Weapons of Democracy: Progressivism, Public Opinion, and Propaganda (Baltimore: Johns Hopkins University Press, 2015); Joseph J. Foy and Timothy M. Dale, eds., Homer Simpson Ponders Politics: Popular Culture as Political Theory (Lexington: University Press of Kentucky, 2013); and Gregory M. Pfitzer, Popular History and the Literary Marketplace, 1840-1920 (Amherst: University of Massachusetts Press, 2008) 
papers and provided researchers with only inconsistent spurts of access to these records until her death in 1975. Besides this issue, many of Dixon's papers are spread throughout a variety of institutional archives and personal collections. The majority of Dixon's novels, however, are available electronically. Besides primary sources, this work draws on diverse historiographies. These include the extensive examination of the Progressive Movement and the Social Gospel, histories of race relations in the U.S., "whiteness studies," imperialism, religious history, and, Southern history. It also includes the new work produced in the "New Southern Studies," a subset of cultural studies, which evaluates regional pretension in a global context. ${ }^{15}$

There are six chapters in this dissertation, each focused on a different time period in Dixon's lifetime. Chapter 1, "A Political Education in Theory and Practice (18791886)," discusses the intellectual contributions of collegiate education at Wake Forest and John Hopkins to Dixon's larger conceptions of citizenship, nation, and history, and his attempt to apply these lessons to North Carolina's politics during a short career as a state legislator. The lessons and experiences gained in colleges shaped Dixon's ideology for the remainder of his life. Chapter Two of this dissertation, "No Difference Between Secular and Divine (1886-1895)," explores the first years of Dixon's ministry in the 1890s. This period is significant for being most liberal period in his life. The third chapter of this dissertation, “The Emergence of White Nationalism in Dixon's Public Works (1896-1901)," explores the major changes in Dixon's ideals about the ideal nation,

\footnotetext{
${ }^{15}$ On the development of "New Southern Studies," see: Michael Kreyling, "Toward 'A New Southern Studies'," South Central Review 22, no. 1 (Spring 2005): 4-18; Kathryn McKee and Annette Trefzer, eds., Global Contexts, Local Literatures: The New Southern Studies (Durham: Duke University Press, 2006); and Harry Stecopoulos, ed., The New Southern Studies and the New Modernist Studies (Iowa City: University of Iowa Press, 2011).
} 
its problems, and the solutions to those problems after he left the Twenty-Third Street Church in 1895. These included a shift away from populist/socialist oriented goals, heavier emphasis on Anglo-Saxon racial theory in his formulation of patriotic millennialism, a new focus on segregation, maintaining white racial purity through antimiscegenation laws, limiting the terms of citizenship, and a more conservative interpretation of federal power that emphasized states' rights. Chapter Four, “The Reconstruction Trilogy (1902-1907)," analyzes Dixon's infamous Reconstruction Trilogy as an argument for white, male suffrage limits, racial separation, individual citizens' activism, and states' rights as key elements in uniting the country and achieving global dominance. He constructed these novels as lesson bearing historical fiction tracts, using the events of Reconstruction to draw parallels to the turn-of-the-century debate over equality, citizenship, and national unity. Chapter Five, "The Anti-Socialism Trilogy (1903-1911)," discusses additional elements of Dixon's return to constitutional conservatism by analyzing a trilogy of lesser-known novels published from 1903-1911. The Anti-Socialism Trilogy further reveals that Dixon's turn-of-the-century return to conservatism extended beyond issues of sectional identity. Chapter Six, "Responses to Dixon's Work (1905-1946)," discusses the various reactions to Dixon's early-twentieth century work, his public justifications for his ideals, as well as the long-term impact of the Reconstruction Trilogy. 


\section{Chapter One}

\section{$\underline{\text { A Political Education in Theory and Practice (1879-1886) }}$}

Radical transformation characterized every aspect of American life and culture from the end of the Civil War to the 1890s. The upheaval in this twenty-five year period revolutionized economics, demography, politics, social order, religious life, intellectual culture, and assumptions about the nature of fundamental institutions, ranging from gender norms and the family to the state. The South endured these changes while working out both a new internal order and resolving its relation to the rest of the country. Born in 1864, Thomas Dixon's early life mirrored these chaotic years with his radical shifts place to place, region to region, and his leaps from one career to another. In the same way, his ambitions pushed him towards some of the most innovative men and institutions of the era, and he became a model and active participant in the transformation of the old order and the introduction of the new. This chapter traces his career in this tumultuous age from his adolescence to 1886 , with particular focus on his educational experience.

During this period of Dixon's life, the South was still in the process of adjusting to the socio-economic conditions of the post-Civil War state. The South was still in the process of adjusting to the socio-economic conditions of the post-Civil War state. The New South movement developed simultaneously. ${ }^{16}$ To facilitate better sectional

\footnotetext{
${ }^{16}$ Historical treatments of the "New South" after the Civil War include: Prince, Stories of the South (2014) and "A Rebel Yell for Yankee Doodle: Selling the New South at the 1881 Atlanta International Cotton Exposition," The Georgia Historical Quarterly 92, no. 3 (Fall 2008); John David Smith, An Old Creed for the New South: Proslavery Ideology and Historiography, 1865-1918 (Carbondale: Southern Illinois University Press, 2008); Tennant S. McWilliams, The New South Faces the World: Foreign Affairs and the
} 
relations, according to the movement's adherents, the South needed to make serious economic and political changes. In short, the South's economy and industries needed to resemble those in rest of the nation. Proponents of the New South wanted to convince the rest of the nation that the region had been reformed, that it was no longer the "backwards" prewar society resistant to change and progress. They were interested in political alliances with capitalists, meant to better the future of both the region and the nation. The New South movement desired reintegration into national life as a viable economic contributor. $^{17}$

In the late-1870s and 1880s, unprecedented levels of political engagement among the working classes, black and white, simultaneously remade postwar North Carolina politics. Grassroots political and labor organizations provided the backbone of this new voting population. The economic depression of 1883 left the working classes demanding government action. The unstable cotton market, North Carolina's major crop in the postReconstruction period, spread socio-economic discontent among the working classes. Simultaneously, labor organizations gained strength in the state. By 1880, African American organizational leaders in North Carolina promoted black solidarity, encouraged political engagement, elected black legislators, and were a viable force in determining the

\footnotetext{
Southern Sense of Self, 1877-1950 (Tuscaloosa: University of Alabama Press, 2007); Edward L. Ayers, Southern Crossing: A History of the American South, 1877-1906 (New York: Oxford University Press, 1995) and The Promise of the New South: Life After Reconstruction (New York: Oxford University Press, 1992); Gaines M. Foster, Ghosts of the Confederacy: Defeat, the Lost Cause, and the Emergence of the New South, 1865 to 1913 (New York: Oxford University Press, 1987); Paul M. Gaston, The New South Creed: A Study in Southern Mythmaking (New York: Knopf, 1970); George Brown Tindall, The Emergence of the New South, 1913-1945 (Baton Rouge: Louisiana State University Press, 1967); and C. Vann Woodward, Origins of the New South, 1877-1913 (Baton Rouge: Louisiana State University Press, 1951).

${ }^{17}$ Prince, “A Rebel Yell for Yankee Doodle," 344.
} 
agenda of the Republican Party. ${ }^{18}$ Throughout the state, the Democratic administration in power's perceived failure to improve social and economic conditions caused the party to two into two factions, often along generational lines: Liberal and Bourbon. ${ }^{19}$ Liberal Democrats criticized the status quo, seeking more direct ways to address the economic issues at hand, while Bourbon Democrats included reconstructed planters, fiscally shrewd legislators, and railroad magnates seeking to minimize change. Many of the state's young Democrats sided with the Liberals, pushing for legislative support to girdle the plans of the New South movement. ${ }^{20}$ Without these changes, Liberal Democrats argued, North Carolina's progress would be hindered. It also caused a rise in the popularity of third parties during the 1880s. In 1886, North Carolinians elected twelve independents to the state House of Representatives, installing this group as the balance of power between the Democrats and Republicans. ${ }^{21}$

The Dixons represent the widespread familial and cultural instability during Reconstruction in the South. The former slaveholding family struggled financially during these years, migrating from home to home. Originally from the Piedmont, they recently

\footnotetext{
${ }^{18}$ Kent Redding, Making Race, Making Power: North Carolina's Road to Disfranchisement (Chicago: University of Illinois Press, 2003), 33-37.

19 'Bourbon' Democrat (the term was used from 1876-1904), referred conservative members of the Democratic Party. Bourbon Democrats usually championed laissez-faire capitalism and advocated banking and business interests. As the century closed, this term became increasingly affiliated with the idea of 'oldfashioned' viewpoints. 'Liberal' Democrats, on the other hand, championed prohibition, labor and farmers' interests, and party reform. For more information, see Kent Redding, Making Race, Making Power: North Carolina's Road to Disfranchisement (Chicago: University of Illinois Press, 2003); Deborah Beckel, Radical Reform: Interracial Politics in Post-Emancipation North Carolina (Charlottesville: University of Virginia Press, 2011); and James Beeby, Revolt of the Tar Heels: The North Carolina Populist Movement, 1890-1901 (Jackson: University Press of Mississippi, 2008).

${ }^{20}$ Lee A. Craig, Josephus Daniels: His Life and Times (Chapel Hill: University of North Carolina Press, 2013), 90-91.

${ }^{21}$ Redding, Making Race, Making Power, 84.
} 
re-settled in North Carolina the in September 1863, after fleeing increasing Union power in Arkansas. The family bought a farm, "Allen's Place," and lacked the labor to continue working the land after freeing their thirty-two slaves following the Emancipation Proclamation. ${ }^{22}$ Convinced they could no longer afford the farm, the Dixons sold the property. They used the last of their savings to open a general store, connected to a white house near the public square in Shelby. ${ }^{23}$ The Dixons maintained this business throughout the early years of Reconstruction. By 1872, they lived on the verge of poverty and the general store home burnt to the ground. ${ }^{24}$ After the financial Panic of 1873, the family moved to a farm on Buffalo Creek, setting up crops and sharecropping tenants for a short time, before moving in with Dixon's maternal grandmother in early $1876^{25}$

Despite the financial and cultural instability of the post-Civil War years, the Dixon family managed to send most of their children to college. Of the three boys and two girls that survived into adulthood, all attended college. At a time when most Southerners failed to attend college, this is remarkable. A.C. Dixon, the eldest brother, enrolled at Wake Forest in 1869 , and graduated in spite of the family's financial woes. ${ }^{26}$

\footnotetext{
${ }^{22}$ Cook, Fire From the Flint, 9-10; Helen C.A. Dixon, A.C. Dixon: A Romance of Preaching, New York: G.P. Putnam's Sons, 1931), 18-19.

${ }^{23}$ Helen C.A. Dixon, A.C. Dixon, 15-19; Thomas Dixon, Sr. owned the general store house/building before the family migrated to Arkansas during the war.

${ }^{24}$ Helen C.A. Dixon, A.C. Dixon: A Romance of Preaching, 9-12; Cook, Fire From the Flint, 32.

${ }^{25}$ Cook, Fire From the Flint, 20-22.

${ }^{26}$ Cook, Fire From the Flint, 32; Thomas Dixon, Sr.'s emphasis on education, as well as the achievements of the Dixon siblings, are key points in Dixon's autobiography and his brother A.C.'s, biography. See Thomas Dixon, The Life Worth Living (1905) and Helen C.A. Dixon, A.C. Dixon: A Romance of Preaching.
} 
Though the Dixon family subscribed to the republican tradition emphasizing the importance of education, financial problems during the prevented young Dixon, from beginning his education before the age of twelve. Living with his grandmother allowed him to attend Shelby Academy, rather than work the fields. He entered formal schooling two years after the end of Reconstruction in 1877. He excelled at schoolwork, particularly languages, oratory, and history. ${ }^{27}$ Regular schooling always fascinated Dixon, and he excelled in his studies, finishing a course in geometry and mastering Latin. $^{28}$ Two short years after enrolling, Dixon's teachers pronounced him prepared for collegiate study.

At Wake Forest University and Johns Hopkins, a combination of new and old intellectual trends formed the foundation for Dixon's interpretations of the world. By the time Dixon returned to Shelby, he had incorporated portions of both the traditional and latest teachings into his beliefs about progress, race, human nature, history, citizenship, education, the role of the federal government, and the importance of participating in local government. Like his older brother, A.C., Dixon attended Wake Forest College in his home state of North Carolina. Wake Forest, a Baptist affiliated institution, was founded in 1834 as the Wake Forest Manuel Labor Institute before becoming a formal college in 1838. The Civil War caused the school to shutter its doors from 1862 to 1866 . After reopening in 1866, the Wake Forest College remodeled its curriculum "in accordance

\footnotetext{
${ }^{27}$ Cook, Fire From the Flint, 33-34.

${ }^{28}$ Ibid.
} 
with the new university system. ${ }^{29}$ A flexible system of seven schools designed to allow students to choose their electives and take any class they were prepared for replaced an inflexible class system. The seven schools included: Latin, Greek, Modern Languages, Mathematics, Natural Science, Moral Philosophy, and The Bible. ${ }^{30}$

The new Wake Forest curriculum, however, followed the typical early-nineteenth century model in its emphasis on Christian piety and moral philosophy. Dixon's courses reveal a diverse list of subjects with assigned readings from staple works of the period. In his first several semesters, he enrolled in courses in Latin with Professor Charles E. Taylor, an American trained academic, Baptist minister, and former Confederate soldier, and in Greek with Professor William Bailey Royall, another Southern veteran, and Mathematics with L.R. Mills. ${ }^{31}$ In addition to these topics, he undertook a class in Natural Science with Professor W.G. Simmons and Assistant Professor William L. Poteat, which included chemistry, physics and astronomy, and natural history. ${ }^{32} \mathrm{He}$ also pursued Modern Languages, which included English, German, and French grammar and literature, taught by Professor William Royall. ${ }^{33}$ The professors assigned standard texts for the period, including Denison Olmsted's Introduction to Natural Philosophy (1840),

\footnotetext{
${ }^{29}$ George Washington Paschal, History of Wake Forest College Vol. II, 1865-1905 (Wake Forest: Wake Forest College, 1943), 9.

${ }^{30}$ Catalogues of Wake Forest College, Forty-Sixth Session, 1879-80 (Raleigh: Edwards, Broughton \& Co., 1880), 16.

${ }^{31}$ Catalogues of Wake Forest College, Forty-Fifth Session, 1879-80, 5-7;Cyclopedia of Eminent and Representative Men of the Carolinas of the Nineteenth Century, Vol. II (Madison, Wisconsin: Brantor Fuller, 1892), 437-440.

${ }^{32}$ Catalogues of Wake Forest College, Forty-Sixth Session, 1880-81, 17-18.

${ }^{33}$ Catalogues of Wake Forest College, Forty-Seventh Session, 1881-82, 7-9.
} 
Worthington Hooker's New Physiology (1874), and Joel Dorman Steele's Fourteen Weeks in Zoology (1877). ${ }^{34}$ Under Thomas Henderson Pritchard and W.B. Royall, Wake Forest's School of Moral Philosophy included logic and rhetoric, mental and moral science, political economy and history, and the evidences of Christianity. ${ }^{35}$ In many ways, this curriculum was already outdated by the time Dixon enrolled in the course. Some of his assigned texts became specific targets of the educational reformers. By the 1870s, intellectuals began discrediting moral philosophy as too theological. Texts such as Butler's Analogy, in the opinion of reformers like G. Stanley Hall, were accused of undermining the purpose of philosophy by presenting a set of established truths drawn solely from theological considerations. ${ }^{36}$

In the early-nineteenth century, religion played a large role in university curriculums. ${ }^{37}$ The rapid industrialization and urbanization of the postwar nation

\footnotetext{
${ }^{34}$ Catalogues of Wake Forest College, Forty-Sixth Session, 1880-81, 5-7.

${ }^{35}$ Catalogues of Wake Forest College, Forty-Seventh Session, 1881-82, 7-9.

${ }^{36}$ Julie A. Reuben, The Making of the Modern University: Intellectual Transformation and the Marginalization of Morality (Chicago: University of Chicago Press, 1996), 89.
}

${ }^{37}$ For more on the history of curriculums at schools, colleges, and universities in the nineteenth century U.S., see: Roger L. Geiger, The History of American Higher Education: Learning and Culture from the Founding to World War II (Princeton: Princeton University Press, 2015); Tova Cooper, The Autobiography of Citizenship: Assimilation and Resistance in U.S. Education (New Brunswick: Rutgers University Press, 2014); Robert B. Townsend, History's Babel: Scholarship, Professionalization, and the Historical Enterprise in the United States, $1880-1940$ (Chicago: University of Chicago Press, 2013); Gary Dorrien, "Social Ethics in the Making: History, Methods, and White Supremacism," in Economy, Difference, Empire: Social Ethics for Social Justice (New York: Columbia University Press, 2010); Colin Heydt, "Hutcheson's 'Short Introduction' and the Purposes of Moral Philosophy," History of Philosophy Quarterly 26, no. 3 (July 2009): 293-309; Marc A. VanOverbeke, The Standardization of American Schooling: Linking Secondary and Higher Education, 1870-1910 (New York: Palgrave Macmillan, 2008); John R. Thelin, A History of American Higher Education (Baltimore: Johns Hopkins University Press, 2004); M. Curtis Hoffman, "Paradigm Lost: Public Administration at Johns Hopkins University, 1884-96," Public Administration Review 62, no. 1 (January-February 2002): 12-23; Julie A. Reuben, The Making of the Modern University: Intellectual Transformation and the Marginalization of Morality (Chicago: University of Chicago Press, 1996); George M. Marsden, The Soul of the American University: From Protestant Establishment to Established Nonbelief (New York: Oxford University Press, 1994); William Bruce Leslie, 
produced a new set of problems for American society, resulting in cries for a collegiate curriculum that prepared students for the new realities of modernity. Educational leaders saw a nation far from ideal. The faith-based curriculum of the early-nineteenth century, many postwar education reformers argued, threatened the nation's intellectual and material progress by failing to include instruction in important modern and practical subjects. ${ }^{38}$ Transatlantic intellectual experiences, specifically between Germany and the United States, shaped the study at the graduate level. Proponents of the so-called "German method" sought to apply the ideal of value-free inquiry to all elements of university education, including subjects previously limited to the realm of theology or philosophy. The development of "scientific history" and "social sciences" resulted from this widespread application of modern scientific method. Proponents of the new system opposed denominational control over institutions of higher education. They maintained that official church sponsorship prevented the exploration of ideas that challenged theological dogma, hindering intellectual progress. Though this suggests religion to be antithetical to intellectual advancement, many reformers believed that the two could be reconciled. Religion could be altered to mesh with new standards of intellectual inquiry by deviating from its traditional doctrines. ${ }^{39}$

Gentlemen and Scholars: College and Community in the 'Age of the University' (University Park: Pennsylvania University Press, 1992); and Stanley M. Guralnick, "Sources of Misconception on the Role of Science in the Nineteenth Century American College," Isis 65, no. 3 (September 1974): 352-366; Laurence R. Veysey, The Emergence of the American University (Chicago: University of Chicago Press, 1965); Jurgen Herbst, The German Historical School in American Scholarship: A Study in the Transfer of Culture (Ithaca: Cornell University Press, 1965); and Frederick Rudolph, The American College and University: A History (New York: Alfred A. Knopf, 1962).

${ }^{38}$ Rueben, The Making of the Modern University, 3-13.

${ }^{39}$ Ibid. 
Charles Darwin's theory of evolution challenged the stable early-nineteenth century relationship between Protestantism and science, as well as religion and morality. ${ }^{40}$ The rapid acceptance of evolution by the scientific community during the last decades of the nineteenth century provoked many Protestant intellectuals to re-evaluate the church's steadfast rejection of the theory. The "new theology" challenged the separation of church and science, arguing that nature itself represented God's will and power. ${ }^{41}$ Evolution, in this perspective, was one of God's many instruments of creation. In this formulation, scientific findings actually bolstered religious beliefs, and the rising popularity of science in American society ensured that any appearance of conflict between science and theology could be disastrous for the future of Protestantism. ${ }^{42}$ To pro-evolution Protestants, science and theology were complementary ways of interpreting God's will on earth; the line between natural and supernatural proved permeable. ${ }^{43}$ Humanity's progress, its very evolution, represented divine revelation revealed

\footnotetext{
${ }^{40}$ For further information on the dynamic relationship between Protestantism and Darwinism in the latenineteenth and early-twentieth century United States, see: David N. Livingstone, Dealing With Darwin: Place, Politics, and Rhetoric in Religious Engagements With Evolution, (Baltimore: Johns Hopkins University Press, 2014) and Darwin's Forgotten Defenders: The Encounter Between Evangelical Theology and Evolutionary Thought, (Grand Rapids, Michigan: W.B. Eerdmams, 1987); Thomas C. Leonard, "Religion and Evolution in Progressive Era Political Economy: Adversaries or Allies?," History of Political Economy 43, no. 3 (2011): 429-469; Peter J. Bowler, Monkey Trials and Gorilla Sermons: Evolution and Christianity from Darwin to Intelligent Design (Cambridge: Harvard University Press, 2007); Richard Ostrander, The Life of Prayer in a World of Science: Protestants, Prayer, and American Culture, 18701930 (New York: Oxford University Press, 2000); Ferenc Morton Szasz, The Divided Mind of Protestant America, 1880-1930 (Tuscaloosa: University of Alabama Press, 1982); Jackson Lears, No Place of Grace: Antimodernism and the Transformation of American Culture, 1880-1920 (New York: Pantheon Books, 1981); and James R. Moore, The Post-Darwinian Controversies: A Study of the Protestant Struggles to Come to Terms with Darwin in Great Britain and America, 1870-1900 (New York: Cambridge University Press, 1979).

${ }^{41}$ Jon H. Roberts, Darwinism and the Divine in America: Protestant Intellectuals and Organic Evolution, 1859-1900 (Notre Dame: University of Notre Dame Press, 2001), 117-188.

${ }^{42}$ Ibid. 118-119.

${ }^{43}$ Ibid, 138-140.
} 
throughout time. ${ }^{44}$ These theological adjustments allowed science and religion to coexist, but also provoked larger questions of God's relationship to everyday life. ${ }^{45}$

Simultaneously, traditionalist Protestants continued refuting the legitimacy of the latest scientific theories, particularly evolution. These Protestants insisted on the infallibility of a literal interpretation of the Bible. ${ }^{46}$ The new university system challenged conservative Protestantism's preference for orthodox piety and theological dogmatism, combined with a classical curriculum. ${ }^{47}$

This caused several rifts between progressive collegiate reformers and traditional Protestant authorities, resulting in the eventual separation of religious authority from the university system. The new university system shifted teaching methods and subject matter, moving away from early-nineteenth century curriculum staples such as moral philosophy in favor of courses emphasizing new, scientific standards and developing academic fields, such as "social science." 48 In the process, certain elements of the earlier

${ }^{44}$ Roberts, Darwinism and the Divine in America, 158-163.

${ }^{45}$ Ibid, 136.

${ }^{46}$ Ibid, 210.

${ }^{47}$ George Marsden, Fundamentalism and American Culture: The Shaping of Twentith-Century Evangelicalism, 1870-1825 (New York: Oxford University Press, 1980), 14.

${ }^{48}$ For more on the emergence of "social science" as an academic field in the late-nineteenth and earlytwentieth centuries, see: Samuel DeCanio, Democracy and the Origins of the American Regulatory State (New Haven: Yale University Press, 2015); Charles Robert McCann, Order and Control in American Socio-Economic Thought: Social Scientists and Progressive Era Reform (New York: Routledge, 2012); Mark C. Smith, Social Science in the Crucible: The American Debate over Objectivity and Purpose, 19181941 (Durham: Duke University Press, 1994); Dorothy Ross, The Origins of American Social Science (New York: Cambridge University Press, 1991); Thomas L. Haskell, The Emergence of Professional Social Science: The American Social Science Association and the Nineteenth-Century Crisis of Authority (Urbana: University of Illinois Press, 1977) and The Authority of Experts: Studies in History and Theory (Bloomington: Indiana University Press, 1984); and Mary Furner, Advocacy and Objectivity: A Crisis in the Professionalization of American Social Science, 1865-1900 (Lexington: University Press of Kentucky, 1975). 
curriculum were incorporated into the new. Many of the up-and-coming intellectuals on the collegiate scene reflect the influence of German approaches to higher education. The tenets of the German graduate seminar, such as an emphasis on objectivity and scientific method, became central elements of the reformed university system, implemented by men educated in Europe. ${ }^{49}$ Reformers, however, did not necessarily advocate the elimination of Christian authority. Their vision of a modern curriculum built on the moral aims of the religious colleges: collegiate education should encompass students' intellectual, moral, and spiritual education. ${ }^{50}$ Protestant morals laid at the heart of the new curriculum, which viewed scientific research and knowledge as tools for societal improvements, and character development with an emphasis on community service, as integral parts of its mission. ${ }^{51}$ Like the traditional religious college, the designers of the modern American university intended the institution to act as a servant of society, dedicated to material and moral improvement. ${ }^{52}$

Dixon's moral philosophy texts provided foundational material for his understanding of the relationship between politics, race, economics, and Protestant ethics, shaping his conception of the ideal nation and its citizens. These topics dominated his assigned readings. Thomas Cogswell Upham's Elements of Mental Philosophy (1831) drew upon the works of traditional Scottish thinkers, such as Archibald Alison's Essay on the Nature and Principles of Taste, Benjamin Rush's Diseases of the Mind, and Thomas

\footnotetext{
${ }^{49}$ Marsden, The Soul of the American University, 153.

${ }^{50}$ Rueben, The Making of the Modern University, 73-77.

${ }^{51}$ Ibid.

${ }^{52}$ Ibid.
} 
Reid's An Inquiry into the Human Mind on the Principles of Common Sense, to analyze the nature of emotions as motives. ${ }^{53}$ Upham concludes that emotions move and control actions. ${ }^{54}$ Though humans have free will, the textbook argues that "God's natural and moral laws" represented a divinely sanctioned measuring stick for human behavior. Upham also alludes to natural theology, which reconciled nature and the divine Scriptures. ${ }^{55}$

For naturalists in the early-nineteenth century, the study of nature demonstrated the truth of the Scriptures, and the Bible, in turn, dictated the interpretation of nature. ${ }^{56}$ Dixon's moral philosophy courses equated natural law with heaven's will, biological racial differences were divinely sanctioned. His natural science text, Hooker's New Physiology (1874), stuck close to the racial theories of the period, offering an overview of the chief classification systems and competing origins theories. It maintained, like the majority of racial science at the time, that the white race occupied the highest place in the racial hierarchy for its mental superiority and larger brain. ${ }^{57}$ The different races were commonly classified according to the system established by Johann Friedrich Blumenbach that separated humans into five racial categories: Caucasian, Ethiopian,

\footnotetext{
${ }^{53}$ Thomas C. Upham, Elements of Mental Philosophy: Abridged and Designed as Textbook for Academies and High Schools (New York: Harper \& Brothers, 1857), 384.

${ }^{54}$ Ibid, 384.

${ }^{55}$ Reuben, Making of the Modern University, 22.

${ }^{56}$ Ibid, 22.

${ }^{57}$ Worthington Hooker, Hooker's New Physiology: Designed as a Textbook for Institutions of Learning (New York: Sheldon and Co., 1874), 311.
} 
Mongolian, American, and Malay. ${ }^{58}$ Hooker's text also discusses competing scientific opinions on the biological origin of racial differences. ${ }^{59}$ According to the work, many early-nineteenth century naturalists believed that the environment shaped race formation, but the theory of polygenesis was gaining academic traction as an alternative. ${ }^{60}$

The application of Christian ethics to politics and nature permeated Dixon's political economy and history courses at Wake Forest. The works of Joseph Bishop Butler and Archibald Alexander offered an explanation of nature through Biblical study. ${ }^{61}$ Other readings emphasized natural theology and ethical duty. The authors of Dixon's moral science and political economy texts, Andrew Preston Peabody and Francis Wayland, shared a belief in natural theology, as well as faith in the importance of Christian morality in political decisions. Peabody's A Manual of Moral Philosophy

\footnotetext{
${ }^{58}$ Hooker, Hooker's New Physiology, 310.

${ }^{59}$ For scholarly analyses of nineteenth and early-twentieth century forms of scientific racism and Social Darwinism, see: Hofstadter (1944), Robert C. Bannister, Social Darwinism: Science and Myth in AngloAmerican Thought (Philadelphia: Temple University Press, 1979); Carl N. Degler, In Search of Human Nature: the Decline and Revival of Darwinism In American Social Thought (New York: Oxford University Press, 1991); Elazar Barkan, The Retreat of Scientific Racism: Changing Concepts of Race in Britain and the United States Between the World Wars (Cambridge: Cambridge University Press, 1992); George Ernest Webb, The Evolution Controversy in America (Lexington: University Press of Kentucky, 1994); Mike Hawkins, Social Darwinism in European and American Thought, 1860-1945: Nature as Model and Nature as Threat (Cambridge: Cambridge University Press, 1997); Lee D. Baker, From Savage to Negro: Anthropology and the Construction of Race, 1896-1954 (Berkeley: University of California Press, 1998); Ronald L. Numbers, Darwinism Comes to America. (Cambridge: Harvard University Press, 1998); Patrick Brantlinger, Dark Vanishing: Discourse on the Extinction of Primitive Races, 1800-1930, (Ithaca: Cornell University Press, 2003); Wendy Kline, Building a Better Race: Gender, Sexuality, and Eugenics from the Turn of the Century to the Baby Boom (Berkeley: University of California Press, 2005); Alexandra Stern, Eugenic Nation: Faults and Frontiers of Better Breeding in Modern America (Berkeley: University of California Press, 2005); John P. Jackson, Jr. and Nadine W. Weidman, "The Origins of Scientific Racism," The Journal of Blacks in Higher Education 50 (Winter 2005/2006): 66-79; and Melissa N. Stein, Measuring Manhood: Race and the Science of Masculinity, 1830-1934 (Minneapolis: University of Minnesota Press, 2015).

${ }^{60}$ Hooker, Hooker's New Physiology: Designed as a Textbook for Institutions of Learning, 310-315.

${ }^{61}$ See Joseph Bishop Butler, Analogy of Religion, Natural and Revealed, to the Constitution and Course of Nature (New York: Harper \& Brothers, 1860) and Archibald Alexander, The Evidences of the Christian Religion (Pittsburg: J.I. Kay \& Co., 1879).
} 
detailed for its readers the basic philosophy of Christian moral duty, rooting it in the theories of Hobbes, Adam Smith, Samuel Clarke, William Paley, Immanuel Kant, and Jeremy Bentham. ${ }^{62}$ Peabody also emphasized political duty and a right to revolution but urged Christian conscience in political decisions. ${ }^{63}$

Dixon's assigned readings emphasized the role of science and Christian morality in bettering the nation, as well as the importance of government and civic activism. Wayland's Elements of Political Economy, for example, exposed Dixon to a formal text placing Christian thought at the center of philosophical truth, maintaining that the principles of Protestant moral philosophy and political economy overlapped. ${ }^{64}$ Early on in the text, Wayland also fused Protestant morality with national wealth and laissez-faire capitalism. He argued that moral, Christian nations received the gift of wealth. Similarly, the work portrayed poverty and wealth inequality as products of personal vice and laziness. Christian morals, in this formulation, control the excesses of the free market economy. Since trade relied on human interaction, mutual dependency ensured moral behavior because the individual interests and social interests intersected.

International trade represented another moral lesson: that God intended different groups of people to live in "friendship and harmony."65 Though Wayland admits the

\footnotetext{
${ }^{62}$ Andrew P. Peabody, A Manual of Moral Philosophy: Designed for Colleges and High Schools (New York: A.S. Barnes and Company, 1873), 207-220.

${ }^{63}$ Ibid, $180-183$.

${ }^{64}$ Edward H. Madden, "Francis Wayland and the Limits of Moral Responsibility," Proceedings of the American Philosophical Society 106, no. 4 (August 1962): 348-349; Donald E. Frey, "Francis Wayland's 1830s Textbooks: Evangelical Ethics and Political Economy," The Journal of the History of Economic Thought 24, no. 2 (June 2002): 216-226.

${ }^{65}$ Frey, "Francis Wayland's 1830s Textbooks," 216-226.
} 
imperfections in his system of moral checks and balances, expressing concerns about bank and stock market fraud, he believed the free market was not the issue; corrupt individuals in the system were the problem. ${ }^{66}$ Wayland's text aimed to be practical; he wanted readers to be familiar with "the laws which regulate the acquisition of wealth" and their moral elements. Finally, Wayland viewed science as the answer to systematic, economic progress. ${ }^{67}$ It was Christian duty, furthermore, to apply these new methods in the service of the nation. Another assigned text, Theodore Dwight Woolsey's Introduction to the Study of International Law, confirmed the same values, as it viewed the state as an agent for the moral betterment of man. ${ }^{68}$ Woolsey also maintained that ethics and political science were interdependent sciences designed to benefit society.

Upon arrival in the fall of 1879, Dixon found Wake Forest possessed a "simple dignity" despite the campus' small size and "poor buildings." He quickly concluded, however, that the college "was a great institution of learning, because the teachers were great men.. ${ }^{, 99}$ As an undergraduate, Dixon achieved high marks, participated in campus organizations, and created his earliest reputation as an orator. He formed many of the traits that marked his later life, particularly his passion for oratory and writing. He proved proficient at languages throughout his career at Wake Forest, winning the French

\footnotetext{
${ }^{66}$ Frey, "Francis Wayland's 1830s Textbooks," 216-226.

${ }^{67}$ Ibid, 231.

${ }^{68}$ Sylvia D. Fries, "Staatstheorie and the New American Science of Politics," Journal of the History of Ideas 34, no. 3 (July-September 1973): 393.

${ }^{69}$ Dixon, Southern Horizons, 153-154.
} 
medal in 1882 earning the highest academic marks possible. ${ }^{70}$ Dixon also garnered a reputation as a splendid orator, which he bolstered as a member of the Euzelian debate society. This literary society helped Dixon feel "at home in the new world the College had created," and he "reveled in the long hours of passionate debate, in which were discussed with vigor and daring of youth, every question under the sun, religious, political, social, and scientific." $" 71$ The young speaker appeared at multiple public debates and earned additional medals. These included the declaimer's medal, and the first place prize in an elocution competition. ${ }^{72}$ To earn his master's degree, Dixon earned "proficiency," awarded when a student learned $75 \%$ of the material in a particular school, in all the curriculum's schools except The Bible. ${ }^{73}$ He won an equal reputation as a writer when he became the corresponding editor (and later the associate editor) of the Euzelian society's monthly magazine, where he published essays and transcripts of previously delivered debates, revealing topics that remained important throughout his life. $^{74}$

Inspired by current events and his Wake Forest curriculum, Dixon's undergraduate works dealt centrally with citizenship and national improvement. Three pieces appeared in the Wake Forest Student, and these are Dixon's first published pieces

\footnotetext{
${ }^{70}$ The Wake Forest Student: A Literary Monthly published by the Euzelian Society 1 no. 7 (July 1882): 329; Cook, Fire From the Flint, 39-48.

${ }^{71}$ Cook, Fire From the Flint, 39; Dixon, Southern Horizons, 156.

${ }^{72}$ The Wake Forest Student: A Literary Monthly published by the Euzelian Society 1 no. 7 (July 1882): 324325; The Wake Forest Student, 1882-1883, Vol. II (Raleigh: Edwards, Broughton \& Co., 1883), 90-91.

${ }^{73}$ Catalogues of Wake Forest College, Forty-Eighth Session, 1882-83 (Raleigh: Edwards, Broughton \& Co., 1883), 20.

${ }^{74}$ The Wake Forest Student: A Literary Monthly published by the Euzelian Society 1 no. 1 January 1882).
} 
revealing his early views on the nation's future, the problems facing the modernizing country, and the history of the Reconstruction era. The first of Dixon's written entries was the transcript of a previous speech titled "The New South."75 Delivered before the two Wake Forest Literary Societies at their anniversary banquet, this piece laid out themes that remained crucial in his mind for decades. In it, Dixon discussed the persistence and elimination of sectionalism, as well as the future place of the South within the nation. This lecture demonstrates that Dixon's understanding of Southern history, and of the relationship between the South and the nation, emerged early in his intellectual development. For him, the South would play a vital role in the construction of a national identity. Fostering reconciliation between the North and South, therefore, was not optional if the country wanted to progress and thrive.

Dixon began this speech with a review of late-nineteenth century sectionalism's origins and the legacy of Reconstruction. Though regional differences contributed heavily to the outbreak of the Civil War, he argued, they were not the root cause of sectionalism in the 1880 s. He identified Reconstruction as the catalyst for lingering postwar regional hatred, describing it as a period of "poverty, misery, woe," and "desolation" exacerbated by a "political fabric...torn into atoms" by freedmen and carpetbaggers that mismanaged their power. ${ }^{76}$ The speech affirmed a faith in regional honor and celebrated its participation in the war effort as defenders of states' rights while

\footnotetext{
${ }^{75}$ Thomas Dixon, "The New South," The Wake Forest Student, 1882-1883 Vol. II (Raleigh: Edwards, Broughton \& Co., 1883), 283-292.

${ }^{76}$ Ibid.
} 
claiming the Ku Klux Klan to be a necessary evil. ${ }^{77}$ In this speech, he presented the restoration of white political dominance the first official step toward national reconciliation, insisting Democratic rule in the South would ensure its economic recovery. The experience of being beaten down by poverty and subject to political domination by uneducated former slaves, Dixon maintained, led white Southerners to form the Ku Klux Klan. The Ku Klux Klan succeeded in restoring conservative Southern whites into political power, but "acts of needless violence" characterized the Ku Klux Klan's last days, he maintained, which disgraced the South and stalled economic recovery by sparking a federal occupation. ${ }^{78}$

Dixon used the rest of his speech to discuss the emergence of a New South and its place in the changing nation. He viewed the New South as a particularly Southern movement, not the imposition of Northern values on the South, arguing its impulse originated with Southern men ready to infuse the region with modernity. Nor did he see the New South an outgrowth of the Old; it was distinctively different. "When the old tree was hewn down" during the Civil War, he maintained, "the old trunk had been cut too close to the ground," preventing progress. The region was forced to "wait for another growth." 79 He defined the New South as a broader change of regional "spirit" linked to an upcoming generation of Southerners. This "spirit is a revival of hope," he claimed,

\footnotetext{
${ }^{77}$ The Ku Klux Klan is a radical white nationalist vigilante organization. A note on language: There have been three incarnations of the Ku Klux Klan in American history: first, the Reconstruction era Ku Klux Klan (1865-1871); second, the early-twentieth century Ku Klux Klan (1915-1944); and third, the contemporary version of the Ku Klux Klan (1970s-present). This dissertation will use the term Ku Klux Klan interchangeably with the organizations' common acronym, KKK.

${ }^{78}$ Dixon, "New South,” 283-292.

${ }^{79}$ Ibid.
} 
after twenty-five years of darkness," and a "life and death struggle with poverty." Young Southerners, he insisted, were open to change, unlike their forebears, and ready to modernize. Their vision of modernization embraced new, cosmopolitan transatlantic perceptions of science, education, and the role of the federal government, like those he was learning at Wake Forest.

Dixon identified this new Southern spirit as the impetus for several changes. First, he argued, it permitted the regional reconciliation needed for material development of the postwar South, which resulted in more varied and profitable industries. Among members of his generation, "who know of that war [the Civil War] only as tradition or history," he saw sectional hatred dying. ${ }^{81}$ Young Southerners, "reared in poverty, amid dreams of wealth," concentrated on "the living, breathing, pulsating questions of the day," rather than perpetuating sectional hatreds. He argued this generation loved "the memory of the old" but refused to "perpetuate the endless quarrel with which it was burdened," realizing that the Civil War's outcome solidified the presence of a powerful federal state, and continued refusal to cooperate with postwar realities could threaten national progress. ${ }^{82}$ In this, Dixon's "new generation" became not only distinctly Southern, but also willing Americans.

The young generation of Southerners, in Dixon's eyes, would rise to influence the country. ${ }^{83}$ He that maintained the entire nation was becoming a new entity, and the New

\footnotetext{
${ }^{80}$ Dixon, "New South," 283-292.

${ }^{81}$ Ibid.

${ }^{82}$ Ibid.

${ }^{83}$ Ibid.
} 
South would form an important part of this modern America. The recent generation of adult Southerners, in his point of view, possessed the experience, education, and ethics to lead the nation. For young Dixon, the up-and-coming generation of Southerners possessed different priorities than their forebears; they were ready and willing to be participants in national life. He predicted that "Southern people," as "born leaders" with naturally supreme oratory and diplomatic skills, "will again shape the nation’s policy." As the New South progressed, so would national reconciliation, ushering in a "revival" and "new start" for the nation's outdated political structures. "The two great political parties," he argued, had "both outlived their usefulness" and were "doomed to certain death" in the modern age. ${ }^{85}$ Though he championed the South, Dixon was "willing to spell nation with a big N" and insisted his suggestions benefitted the interests of the country as a whole. ${ }^{86}$

The most prominent theme in Dixon's earliest published works was the important role of an educated citizenry in American politics. Two out of three of his Wake Forest pieces focused on the need for suffrage reform. The second article of the three covered his contribution to a public debate over whether or not universal suffrage was "conducive to the best interests" of the nation. ${ }^{87}$ This short article reported that Dixon condemned universal suffrage on the grounds that it enabled political corruption through the

\footnotetext{
${ }^{84}$ Dixon, "New South," 283-292.

${ }^{85}$ Ibid, 291.

${ }^{86}$ Ibid.

87 "Is the System of Universal Suffrage Conducive to the Best Interests of the Republic?" The Wake Forest Student, 1881-1882, Vol. I (Raleigh: Edwards, Broughton \& Co., 1882), 144-147.
} 
manipulation of uneducated voters. To fix the flaws of the current system, Dixon recommended an educational qualification for voter registration. Universal education must exist alongside universal suffrage in order for the idealistic system to function properly, he insisted. ${ }^{88} \mathrm{He}$ argued that the founding concept of "all men... born free and equal, is erroneous" because it grants "ignorance and sloth... equal consideration with knowledge and virtue." Dixon believed the "dull, untutored intellect" could not "pierce the mazy labyrinth of governmental machinery." Illiterate men could not make an intelligent decision, he asserted, creating opportunities for demagogues to influence political policy via these impressionable voters, which threatened the stability of the nation. He assumed an educated voting public could see through the lies of corrupt politicians. $^{89}$

Dixon furthered his case for suffrage reform in his third published essay. Titled "The Coming Question," this work discussed "the great question upon the American people:" "Who shall govern America?"90 Suffrage reform, he maintained, offered a solution to the nation's "dangerous if not fatal disease" caused by "power entrusted to ignorance." He identified four "symptoms" of national degeneration linked to uneducated voters. $^{91}$ They included widespread corruption among politicians that chose partisan lines in "utter disregarded of national welfare," "the power and influence of the

\footnotetext{
88 "Is the System of Universal Suffrage Conducive to the Best Interests of the Republic?" The Wake Forest Student, 1881-1882, Vol. I (Raleigh: Edwards, Broughton \& Co., 1882), 144-147.

${ }^{89}$ Ibid.

${ }^{90}$ Thomas Dixon, "The Coming Question," The Wake Forest Student, 1881-1882, Vol. I (Raleigh: Edwards, Broughton \& Co., 1882), 295-298.

${ }^{91}$ Ibid.
} 
demagogue," increasing "undue influence of wealth in the political world," and "a sentiment of lethargy" among good and virtuous citizens. Uninformed voters' political power, Dixon's essay maintained, perpetuated corruption and demagoguery, causing educated citizens to "lose faith in the integrity and purity" of the government and neglect their duties at the ballot box..$^{92}$

Dixon emphasized a need for the system to reform according to the dictates of the era since the voting constituency had changed significantly since the Founding Fathers declared universal human rights. ${ }^{93}$ He argued that newly freed African American voters and years of mass European immigration complicated the implementation and acceptability of universal male suffrage rights. He believed that granting suffrage to groups that had "skipped a long age in the process of progressive development," endangered the country and that "universal teaching should precede universal enfranchisement." ${ }^{94}$ An educational requirement ensuring voters' basic knowledge of the political system, he insisted, would be "the first and most important step toward thoroughly Americanizing the hordes of immigrants" flooding the country. ${ }^{95}$ Establishing an educational qualification for voters would not only eliminate political corruption and the influential power of wealth, he predicted, it would "elevate and dignify citizenship" by causing "slumbering intellectuals" to "wake to the fact that to be a

\footnotetext{
${ }^{92}$ Dixon, “The Coming Question, 295-298.

${ }^{93}$ Ibid.

${ }^{94}$ Ibid.

${ }^{95}$ Ibid.
} 
sovereign citizen of America means something" and reviving interest in the country's welfare. $^{96}$

By the time he graduated from Wake Forest in 1882, Dixon had developed an impressive academic record, a love of public debate, oratory, and writing, talent for speaking, and he discussed themes that remained seminal in the coming decades of his life. His conservative curriculum emphasized the prevalence and importance of Christian ethics in nature, politics, and economics, and also championed both the state and scientific advancements as tools capable of bettering the country. Suffrage reform, educated citizens, and reconciliation emerged as vital themes in Dixon's earliest works, representing the first of many commentaries on these topics.

In 1883, Dixon's intellectual development continued at the Johns Hopkins University in Baltimore, Maryland, where he decided to pursue a doctorate in history and political science after earning a scholarship. The curriculum at Johns Hopkins differed significantly from his primarily conservative studies at Wake Forest. Hopkins epitomized the new university philosophy. Founded in 1876, the university incorporated the newest standards of higher education into an "enlightened Christian" framework. ${ }^{97}$ This included an emphasis on scientific methods, original research, and an academic openness conducive to advancing scientific research. The "German method" of graduate education, which centered on empirical investigation, formed an important part of Hopkins' structure and teaching methods. ${ }^{98}$

\footnotetext{
${ }^{96}$ Dixon, “The Coming Question, 295-298; italics are Dixon's.

${ }^{97}$ Marsden, Soul of the American University, 150-153.

${ }^{98}$ Ibid.
} 
At Johns Hopkins, Dixon studied with the two of the most important academic intellectuals in the United States: Herbert Baxter Adams and Richard T. Ely. Both of these professors revolutionized the American intellectual landscape. Adams earned a reputation as the bearer of German-based scientific methods, while Ely became known as a progressive economist and reformer. Though Dixon left little record of his time at Hopkins, understanding the curriculum and beliefs of his professors is vital to understand his life's work. Adams dominated Dixon's course schedule, teaching three of his classes, including the history core seminar, American history, and international law. He also undertook Ely's course in political economy. By the time he left Johns Hopkins, Dixon claimed to have been "taught to revalue all things" and "to try them in the crucible of the eternal principles of justice and right." 99 This sense of moral objectivity became a prominent factor in his ideology.

Herbert Baxter Adams (1850-1901) revolutionized history in the United States. ${ }^{100}$ First, he introduced Americans to the formal professional academic discipline of

\footnotetext{
${ }^{99}$ Dixon, Southern Horizons, 167.

100 There is currently no modern biographical study of Herbert Baxter Adams. Most explorations of Adams are found in the works addressing curriculum reform in the late-nineteenth and early-twentieth centuries (see previous footnote). For more on solely on Adams and his legacy, see: Walter Conard Gass, "Herbert Baxter Adams and the Development of Historical Instruction in American Colleges and University," Ed.D. Dissertation, Duke University (1963); Gerald Joseph Flood, "Herbert Baxter Adams and the Study of Education," Ph.D. Dissertation, Johns Hopkins University (1970); Bruce David Saunders, "Herbert Baxter Adams and the Development of American Higher Education, 1876-1901," Dissertation, University of Texas at Austin (1975); Raymond J. Cunningham, "Is History Past Politics? Herbert Baxter Adams as a Precursor of "The New History,", The History Teacher 9, no. 2 (February 1976): 244-257 and "The German Historical World of Herbert Baxter Adams: 1874-1876," The Journal of American History 68, no. 2 (September 1981): 261-275; and John Higham, "Herbert Baxter Adams and the Study of Local History," The American Historical Review 89, no. 5 (December 1984): 1225-1239.
} 
history. ${ }^{101}$ Adams was one of several German-trained American professors incorporating new standards, practices, and assumptions into the discipline. He absorbed many of his philosophies and convictions from his graduate career at universities in Heidelberg and Berlin. This involved new ideas about history as a science with the examination of primary sources and documents. Self-conscious explorations into the purpose, methods, and interconnectivity of historical study provided the foundation of German method, which emphasized the importance of empirical scientific research. Critical analysis of these primary documents formed the crux of the German seminar system, where students discussed their accuracy and meaning using objective methods of science. The Hopkins history seminar's main principle was the encouragement of independent thought and scientific research, including interdisciplinary connections. ${ }^{102}$ Adams' seminar in history and political science resembled the German model with "a special interest municipal history" and economics. ${ }^{103}$ This method made the pursuit of history an "active instead of passive process." ${ }^{104}$ Advanced students met twice a week, once to study primary sources

\footnotetext{
${ }^{101}$ For further research regarding the professionalization of history during the nineteenth and twentieth centuries in the United States, consult: Robert B. Townsend, History's Babel: Scholarship, Professionalization, and the Historical Enterprise in the United States, 1880-1940 (Chicago: University of Chicago Press, 2013); Michael Kammen, "The American Past Politicized: The Uses and Misuses of History," Annals of the American Academy of Political and Social Science 617 (May 2008): 42-57; Ian Tyrrell, "Making Nations/Making States: American Histories in the Context of Empire," The Journal of American History 86, no. 3 (December 1999): 1015-1044; Bonnie G. Smith, "Gender and the Practices of Scientific History: The Seminar and Archival Research in the Nineteenth Century," The American Historical Review 100, no. 4 (October 1995): 1150-1176; and Isaiah Berlin, "History and Theory: The Concept of Scientific History," History and Theory 1, no. 1 (1960): 1-31.

${ }^{102}$ Herbert Baxter Adams, "Special Methods of Historical Study as Pursued at the Johns Hopkins University and Formerly at Smith College," 113, 126-127.

${ }^{103}$ Herbert Baxter Adams, The Study of History in American Colleges and Universities (Washington, D.C.: Government Printing Office, 1887), 173-175.

${ }^{104}$ Adams, "Special Methods of Historical Study as Pursued at the Johns Hopkins University and Formerly at Smith College," 132.
} 
of early European history "with special reference to Germanic peoples," and again for lectures and original papers on local institutions. ${ }^{105}$ Topics covered in the seminar included a broad range: the German methods of writing and teaching history, multiple localized historical events, the "limits of cooperation," the "socialistic and cooperative features of Mormonism," Machiavelli, Locke's political philosophy, income taxes, tariffs, and the census of $1880 .^{106}$

Like many other educational reformers of the period, Adams sought to build a curriculum aimed at educating American public servants through lessons in politics, economics, history, law, and ethics. ${ }^{107}$ At Johns Hopkins, Dixon learned a very specific definition of history and the functions of the state. Adams defined history as "past politics and politics present history." 108 He used a classical interpretation of "politics," which encompassed the whole domain of civilized society, including its culture. For Adams, the state represented the supreme embodiment and sustainer of civilization. ${ }^{109}$ Possibilities existed, in Adams' calculations, for "the real progress of historic and economic science alike" in the development of a new generation. ${ }^{110}$ Trained in the proper methods, these men could expand "local consciousness into a fuller sense of its

\footnotetext{
${ }^{105}$ Adams, The Study of History in American Colleges and Universities, 173-176.

${ }^{106}$ Ibid.

${ }^{107}$ M. Curtis Hoffman, "Paradise Lost: Public Administration at Johns Hopkins University, 1884-96," Public Administration Review 62, no. 1 (January-February 2002): 12.

${ }^{108}$ Herbert Baxter Adams, "Special Methods of Historical Study as Pursued at the Johns Hopkins University and Formerly at Smith College," 126-127.

${ }^{109}$ Ibid, 250-252.

${ }^{110}$ Adams, "Special Methods of Historical Study as Pursued at the Johns Hopkins University and Formerly at Smith College," 126-127.
} 
historical worth and dignity," providing the context for the flourishing of national and international life. Adams viewed local history and popular education as beginning points for national history and the foundation of good American citizenship. ${ }^{111}$

In addition to the form of the historical discipline, Adams absorbed and taught the ideological values of the Germans, not least racial theory. He taught the theory of AngloSaxonism, which argued that Western civilization originated in Germanic, or Teutonic, cultures and identified the modern democracy as a trait exclusive to the Germanic races. ${ }^{112}$ Anglo-Saxonism also emphasized scientific approaches to historical evidence, maintaining they cannot be understood without the proper context. ${ }^{113}$ The Hopkins professor's research emphasized the local, inherited nature of Anglo-Saxon democratic political values and their influence in the United States. He insisted democratic tradition in the United States originated with its Northern European heritage. ${ }^{114}$ Anglo-Saxon intellectual culture, in Adams' publications, influenced America's political evolution, and remained a vital part of its success. His work presented reform movements and

\footnotetext{
${ }^{111}$ Adams, "Special Methods of Historical Study as Pursued at the Johns Hopkins University and Formerly at Smith College," 126-127.

${ }^{112}$ For more on Anglo-Saxonism, also known as Teutonism, see: Reginald Horsman, Race and Manifest Destiny: The Origins of American Racial Anglo-Saxonism (Cambridge: Harvard University Press, 1981); Stuart Anderson, Race and Rapprochement: Anglo-Saxonism and Anglo-American Relations, 1895-1904 (Rutherford: Fairleigh Dickinson University, 1981); Allen J. Frantzen and John D. Niles, eds., AngloSaxonism and the Construction of Social Identity (Gainesville: University Press of Florida, 1997); Paul A. Kramer, "Empires, Exceptions, and Anglo-Saxons: Race and Rule Between The British and the United States Empires, 1880-1910," The Journal of American History 88, no. 4 (March 2002): 1315-1353; Eric P. Kaufmann, The Rise and Fall of Anglo-America (Cambridge: Harvard University Press, 2004); Ritchie Devon Watson, Normans and Saxons: Southern Race Mythology and the Intellectual History of the American Civil War (Baton Rouge: Louisiana State University Press, 2008); and Bluford Adams, "World Conquerors or a Dying People? Racial Theory, Regional Anxiety, and the Brahmin Anglo-Saxonists," The Journal of the Gilded Age and Progressive Era 8, no. 2 (April 2009): 189-215.

${ }^{113}$ Cunningham, "Is History Past Politics?," 244-257.

${ }^{114}$ Herbert Baxter Adams, The Germanic Origins of New England Towns (Baltimore: John Murphy \& Co., 1882), 6-8.
} 
empowered local governments as a restoration of historical traditions instead of a radical departure from the status quo. ${ }^{115}$ Adams' incorporation of the "survival of the fittest" Social Darwinian theories of Herbert Spencer also justified, for many of his students, Anglo-Saxon supremacy. ${ }^{116}$

Besides the powerful influence of Herbert Baxter Adams, Dixon encountered the significant figure of Richard T. Ely in the political economy course at Johns Hopkins. A political economist by training, Ely's many books, public activism, and accomplished graduate students disseminated his beliefs into American culture. ${ }^{117}$ Many of his works on political economy became standard academic texts. The tenets of the German Historical School provided the foundation for his interpretation of political economy. German academics' application of scientific methods, and the notion that "all economic truths are purely relative and valid only for a specific set of national and historical circumstances," formed the basis for Ely's progressive approach to political economy. ${ }^{118}$ He also incorporated the German school's method of criticizing past economic thought in order to understand the next stage of developmental growth. For Ely, federally instituted social policies formed a critical part of future economic success. His works helped alter Americans' perceptions of the economy and the role of the federal government. He

\footnotetext{
${ }^{115}$ Hoffman, "Paradise Lost," 14.

${ }^{116}$ For a concise history of Social Darwinism and Spencer, see Mike Hawkins, Social Darwinism in European and American Thought, 1860-1945 (Cambridge: Cambridge University Press, 2007).

${ }^{117}$ Consult the following for more on Richard T. Ely: Benjamin G. Rader, The Academic Mind and Reform: The Influence of Richard T. Ely in American Life (Lexington: University of Kentucky Press, 1966) and Luigi Bradizza, Richard T. Ely's Critique of Capitalism (New York: Palgrave Macmillan, 2013).

${ }^{118}$ Bradizza, Richard T. Ely's Critique of Capitalism, 2.
} 
called for an active government structure that would use modern science to change society and ensure the full development of each citizen. ${ }^{119}$

Late-nineteenth century political economists, like Ely, sought scientific solutions to tangible, modern-day problems. Often, government action via legislative reform was their recommendation. Ely believed the present moment offered vast opportunities for certain reforms because the nation was still young and its "institutions and habits of thought are plastic to an unusual degree." ${ }^{\prime 20}$ America could avoid many of the evils plaguing European nations by studying economic history. ${ }^{121}$ Since the science of economics centered on "humanity, the beginning and end of all economics," Ely became preoccupied with the period's most blatant ethical issue, labor conditions. ${ }^{122} \mathrm{He}$ published extensively on labor issues and economic theories, socialism in particular. Labor problems and their potential solutions formed a pivotal part of Ely's political economy. Ely viewed the late-nineteenth century labor movement as "the struggle of the masses for existence" that would determine the future welfare of humanity. ${ }^{123} \mathrm{He}$ believed scientific research should undergird any serious decision on the issue, and that change needed to proceed through legal channels rather than through violent protests. ${ }^{124}$

\footnotetext{
${ }^{119}$ Bradizza, Richard T. Ely's Critique of Capitalism, 2.

${ }^{120}$ Richard T. Ely, The Labor Movement in America (New York: Thomas Y. Crowell \& Co., 1886), v-vi.

${ }^{121}$ Ibid.

${ }^{122}$ Richard T. Ely, "Economic Theory and Labor Legislation," American Economic Association Quarterly 9, no. 1 (April 1908): 124-125.

${ }^{123}$ Ely, The Labor Movement in America, iv-vi.

${ }^{124}$ Ibid, $\mathrm{x}$.
} 
Economic reform, in these calculations, "required the united efforts, each in its own sphere, of the church, of the state, and of science., ${ }^{, 125}$

Dixon's time at Johns Hopkins, though important in his intellectual development, was short-lived; he left at the end of the fall semester in 1883. Intersections between Dixon's ideals and those of his Hopkins professors, however, dominate his later sermons, speeches, novels, stage plays, and films. At Johns Hopkins, Dixon's interest in constructing a successful country received impetus from Adams' and Ely's emphasis on local political activism as the key to national change. The professors' insistence on the authority of scientific research methods turned this link between national and local into an accepted fact of the time. Dixon's scientific education and training in graduate school resulted in his lasting faith in objectivity. The importance of Christian ethics in politics the young man learned at Wake Forest also received increased academic endorsement at Johns Hopkins, but with a stronger emphasis on the state's responsibility to perpetuate Protestant visions. Ely's insistence on a coalition of religious and intellectual values in reform politics, and his view of the state as a tool for Christian-based progressive agendas, as one example, played a large role in Dixon's anti-capitalist reform impulses of the 1890s. Adams and Ely also provided Dixon with tools to justify his previous attitudes toward racial hierarchy and uneducated voters. Both professors believed in the importance of education for American voting citizens, reinforcing Dixon's undergraduate assertions that education provided the key for a successful nation. Simultaneously, the Anglo-Saxon version of history that permeated Adams' seminar justified Dixon's view

\footnotetext{
${ }^{125}$ Ely, "Economic Theory and Labor Legislation," 124-125.
} 
that white, educated men were more capable rulers than people of color, building on the racial hierarchies learned at Wake Forest. It also linked America's power with its whiteness.

From 1883 to 1886 , Dixon underwent a series of life changes, during which he explored new careers and interests. He sought fame in New York City, returned back to North Carolina, earned a law degree, opened a legal office, was married, and ran for state office - all before turning twenty-one. The first of these changes originated with a passion for theatre, which Dixon developed while at Johns Hopkins. He viewed the stage as tool for spiritual renewal, capable of healing an individual by transporting their mind to another sphere. ${ }^{126}$ During his four months in Baltimore, from August to December 1883, Dixon attended multiple plays and decided to leave academia to concentrate on a dramatic career. ${ }^{127}$ The following January, despite protests from his friends and family, he left for New York City to pursue stage fame on his twentieth birthday. ${ }^{128}$ After returning to Shelby in spring 1884, he attended Mardi Gras in New Orleans and met his future wife Harriet Bussey, daughter of Dr. J.W. Bussey of Columbus, Georgia. ${ }^{129}$ They eloped the following year. ${ }^{130}$

Dixon's first period of time in New York changed the trajectory of his career and exposed the young man to the city's intellectual currents. In the city, Dixon attended

\footnotetext{
${ }^{126}$ Thomas Dixon, Jr., "Notes by a Stage-Struck Youth," The Wake Forest Student 3, no. 6 (February 1884): 230 .

${ }^{127}$ Ibid.

${ }^{128}$ Ibid, 53.

${ }^{129}$ Ibid, 61-62.

${ }^{130}$ Ibid.
} 
plays, lectures, and sermons by some of the period's most influential figures. The intellectual atmosphere of New York enriched his development. Public appearances by Robert Ingersoll and Henry Ward Beecher exposed Dixon to some of the pre-eminent speakers of the period. Though impressed with Ingersoll, he left Plymouth church in Brooklyn convinced Beecher was "the greatest preacher in the world." 131 The ideological differences between Beecher and Ingersoll returned in Dixon's later career, as he championed Beecher's liberal Protestantism and condemned Ingersoll's atheism. During his early time in New York, however, the two men represented a small selection within the city's vast intellectual culture. He enrolled at the Frobisher School to study dramatic method, but found the theater world vastly competitive. Although an ambitious and talented public speaker, theater companies informed him that his six foot three inch, one hundred and fifty pound physique would "make success as an actor a very difficult, if not impossible thing." ${ }^{\prime 132}$ One recommended that, if truly interested in the dramatic world, he use his university training to "forget acting and write" to assist in filling the void of American authored plays. ${ }^{133}$ In early 1884, after months of failed attempts to secure a stage career, Dixon returned to North Carolina "determined to resume... study of the stage at some later day under more favorable conditions." ${ }^{134}$

Back in North Carolina, Dixon continued testing new careers and interests while incorporating the lessons of his collegiate experience into these efforts. Dixon enrolled

\footnotetext{
${ }^{131}$ Dixon, "Notes by a Stage-Struck Youth,” 231-232.

${ }^{132}$ Cook, Fire From the Flint, 55.

${ }^{133}$ Ibid, 56.

${ }^{134}$ Dixon, Southern Horizons, 170.
} 
in law school, set up a small practice, and helped establish a local theater troupe. ${ }^{135}$ At the suggestion of his father, Dixon heeded the pleas of his graduate professors. He became a public servant, the youngest member of the North Carolina General Assembly House of Representatives. ${ }^{136}$ The two short years between the time Dixon campaigned for office and announced his retirement from the position, from 1884 to 1886 , proved crucial in the formation of his later beliefs about politics and society. The sources from this period, moreover, illustrate the continuity of Dixon's collegiate ideals. His campaign platform emphasized principles from his college years. His speeches, as reported in the newspapers of the period and as remembered in his autobiography, resemble his collegiate ideas about the New South, national progress, and Southern history. Once elected, he sought to remedy the state's economic problems by introducing bills establishing a Confederate veterans' pension, to redistribute tax burdens, diversifying the economy, and funding industrial schools. New elements of Dixon's ideology also formed in these years. The first was a grand disillusionment with politics and law, which convinced Dixon of both institution' innate corruption. The second was a newfound appreciation for the Church, resulting in his decision to become a Baptist minister, like his father.

Dixon's time in the legislature reflects the influences of both historical trends and the traits he acquired in college. One local newspaper labeled Dixon an "illustrious example" of the "young element" in society and politics asserting "its claim to

\footnotetext{
${ }^{135}$ Dixon, Southern Horizons, 171-172.

${ }^{136}$ Ibid.
} 
recognition in shaping the policy of communities and States." ${ }^{\prime 137}$ The article credited Dixon's "good parentage on both sides" for "a large share of his character and intellect," which had won over the Cleveland County voters "simply upon the merit of the candidate made known to an honest and intelligent people."138 Though he touted progressive reforms, North Carolina's voters viewed Dixon as "aggressive enough to believe the world moves, and conservative enough to stay clear of dangerously and venturesome legislation."139 Dixon's campaign platform struck a balance, appealing to both sides of the generational divide. In public debates during his campaign, Dixon praised the political work of his elders, but demanded "a chance for the younger generation to be heard." ${ }^{140}$ Here, his ideas also parallel those of his Wake Forest writings. To him, the twenty years of development since the war's end resulted in a "new world with new issues," which required a "New South, a New Nation, and a New Deal for a new generation" to accompany it. ${ }^{141}$ His campaign speeches received heavy praise from audiences statewide. During the election, Dixon carried every township in the county, but one. ${ }^{142}$

\footnotetext{
137 "Thomas Dixon: The Youngest Legislator in the Country, Not Old Enough to Vote at the Election that Made him Member of the N.C. Legislature from Cleveland County," The Western Sentinel (WinstonSalem, North Carolina), April 30, 1885.

${ }^{138}$ Ibid.

${ }^{139}$ Ibid.

${ }^{140}$ Dixon, Southern Horizons, 173-174.

${ }^{141}$ Ibid, 174.

142 "Charlotte Observer," The Wilmington Morning Star (Wilmington, North Carolina), October 2, 1884; News and Observer (Raleigh, North Carolina), October 1, 1884.
} 
Dixon's faith in educated citizen activism and government reform as solutions to the economic issues of the period led him to help organize Raleigh's Watauga Club in 1884. This organization intended "to promote the material interests" of the community and "the whole people of North Carolina," and included several other men of prominence: Josephus Daniels, Arthur Winslow, Walter Hines Page, William S. Primrose, and Charles W. Dabney. ${ }^{143}$ Like Dixon, other members of the club believed in the importance of education and government legislation for furthering the state's material progression. The reform efforts of Dixon and the Watauga Club included a belief in education as key to social progress, the importance of the government in perpetuating socio-economic change, and white supremacy as the "solution" to racial tensions in the state. The Watauga Club mainly focused on the establishment of an industrial school during Dixon's time as a legislator. The school was one part of the club's larger project of agricultural diversification and government reform designed to initiate material progress. "Intelligent labor is the basis of our civilization," the Watauga Club maintained, and "people are of right entitled to an institution where the best methods of manual labor may be taught." ${ }^{144}$ The young men in the organization argued such a school fulfilled the "duty of the State to her sons as she increases their demands upon society by education, to open up to them and multiply the avenues of legitimate occupations.. ${ }^{145}$ In 1885, the Watauga Club published a "Memorial to the Legislature," requesting the

\footnotetext{
143 "Constitution of the Watauga Club," Watauga Club Records, 1884-2011, Special Collections Research Center at North Carolina State University Libraries, NCSU Libraries' Digital Collections: Rare and Unique Materials, http://d.lib.ncsu.edu/collections/catalog/mc00229-001-bx0001-002-001, viewed April 18, 2014.

144 “Letters From Prominent Gentlemen," Weekly State Chronicle (Raleigh, North Carolina), November 13, 1885.

${ }^{145}$ Ibid.
} 
General Assembly "establish an Industrial School in North Carolina, which shall be a place for young men who wish to acquire skill in the wealth producing arts and sciences." 146 The Wataugans defined these categories as "woodwork, mining, metallurgy, and practical agriculture, and in such other branches of industrial education that may be expedient." They asked the General Assembly to allocate funds to build the institution in Raleigh, in direct connection with the State Agricultural Department. ${ }^{147}$

Dixon invested heavily in the idea of the New South during college, and, as a legislator, wanted to be sure his home state participated in the movement. Dixon believed a "new spirit is abroad in the Old Commonwealth" where "Progress is the watch word of the hour." ${ }^{148}$ The state was entering "an industrial expansion after twenty years of struggle against starvation" that required committing the "full force of our energy to this development." ${ }^{149}$ At the last minute, with only six days before the deadline, he took full responsibility for the design and construction of Cleveland County's exhibit at the 1884 Southern Exposition in St. Louis. ${ }^{150}$ The Exposition put the American South's newest technological and industrial developments on display. Exhibits were intended both to demonstrate a locale's advancements, as well as to attract capital to the area. In the Cleveland county exhibit, Dixon portrayed the region as diverse in resources, industries, and potential for growth. Dixon chose to emphasize the Carolina sewing

\footnotetext{
146 "Memorial to the Legislature," The People's Press (Winston-Salem, North Carolina), February 5, 1885.

${ }^{147}$ Ibid.

${ }^{148}$ Dixon, Southern Horizons, 177-178.

${ }^{149}$ Ibid.

150 “Cleveland County,” News and Observer (Raleigh, North Carolina), October 10, 1884.
} 
machine in the exhibit, placing it front and center. Also included in the exhibit were geological specimens, including "the only tin ore found in America... that... will affect the markets of the world," quartz, and plumbargo. The display made sure to inform viewers of ten recently discovered, underworked mines in the county where such mineral might exist. A variety of foodstuffs formed a good portion of the exhibit's goods, such as yarn from local mills, Piedmont made wine, apples, dried fruits, sorghum molasses, tobacco, wool, and forty varieties of cotton. ${ }^{151}$ At the Southern Exposition, Dixon wanted to maximize Cleveland County's economic potential.

As a legislator, Dixon enthusiastically embraced his duties as a public servant. While in office, Dixon served on the Committee on Finance, the Committee on Insurance, the Committee on Immigration, the Committee on Education, and the Committee on Enrolled Bills. ${ }^{152}$ His addresses to the legislature in support of, or against, certain bills illustrate how Dixon applied different elements of his ideology into formal political action. The debates and proposed bills within the General Assembly meeting of 1885 also reflect the influence of the agricultural labor movement, the persistence of arguments over education, as well as the agenda of the New South movement. Both Liberal Democrats and Republicans sought to improve the state's education system. Throughout 1885, the House of Representatives debated and passed bills to establish normal schools and industrial colleges in different locales throughout the state. ${ }^{153}$ Many

\footnotetext{
151 “Cleveland County,” News and Observer (Raleigh, North Carolina), October 10, 1884.

152 Journal of the House of Representatives of the General Assembly of the State of North Carolina at the Session of 1885 (Raleigh: Ashe \& Gatling, State Printers and Binder, 1885), 25, 35, 47, 667.

${ }^{153}$ Ibid.
} 
local organizations demanded the repeal of fence laws, and the legislature debated bills designed to appease these constituents, reflecting the increasing power of grassroots politics. ${ }^{154}$ Most of the bills and debates over proposals concerned local debts, local taxation, prohibition, railroads, altering fence laws, and establishment of schools. The House approved the incorporation of multiple railroads to facilitate economic growth. ${ }^{155}$ The General Assembly sought to resolve economic problems and negotiated the emerging suggestions for political reform.

The major bills proposed by Dixon during his time as a legislator reveal his continuing faith in education and reform as answers to economic ills. Dixon championed industrial education for whites, new taxes, and benefits for Confederate veterans. ${ }^{156}$ All three bills sought to eradicate one part of the economic situation in North Carolina. A bill to provide Confederate veterans with pensions proved Dixon's most successful venture while in the General Assembly. It connected the progress-minded focus of the New South with the veneration of previous generations. Dixon argued that many Confederate veterans in the state suffered while its younger peoples concentrated on progress. In his speech to the house of representatives regarding his proposed bill, Dixon implored his fellow politicians to remember their "painfully straggling along....wounded comrades, forgotten in their distress" and living "amid the dirt and dust and misery of the

\footnotetext{
${ }^{154}$ Beckel, Radical Reform, 126.

${ }^{155}$ Journal of the House of Representatives of the General Assembly of the State of North Carolina at the Session of 1885 (Raleigh: Ashe \& Gatling, State Printers and Binder, 1885), 458-459, 494, 542, 552-553, $568,660,720$.

${ }^{156}$ Ibid, 89, 204-205, 587, 723.
} 
direst poverty" that existed along the "road to prosperity."157 "An Act for the Relief of Certain Soldiers of the Late War Between the States" provided government funds "for the use and benefit of disabled officers, soldiers, and sailors of North Carolina, who, while citizens of the state, lost a limb, or have a limb... paralyzed and useless by reason of a wound received in the service of the states." ${ }^{\prime 158}$ It was widely praised, becoming the first such bill signed into state law and inspiring other Southern states to adopt similar measures.

The political debate over educational funding remained a crucial theme during Dixon's time in the General Assembly, as its members negotiated issues of state responsibility. Throughout 1885, the House of Representatives debated bills to establish normal schools and industrial colleges in different locales throughout the state. ${ }^{159}$ Often, bills requesting the construction of normal schools received legislative approval, while the issue of industrial education remained undecided. Dixon believed an industrial school would ensure white North Carolinians' could receive an education, enabling success in the modern world. While in office, Dixon introduced a bill to accomplish this goal. Built on the demands of the Watauga Club, the bill proposed an industrial school connected to the State Agricultural Department. ${ }^{160}$ The bill did not pass the Senate vote, but a modified version passed two years later to establish the North Carolina College of

\footnotetext{
${ }^{157}$ Dixon, Southern Horizons, 177-178.

158 "House of Representatives Calendar," The Newton Enterprise (Newton, North Carolina), February 6, 1885.

159 Journal of the House of Representatives of the General Assembly of the State of North Carolina at the Session of 1885 (Raleigh: Ashe \& Gatling, State Printers and Binder, 1885), 723.

${ }^{160}$ Ibid.
} 
Agricultural and Mechanic Arts (later North Carolina State University), which only admitted whites. ${ }^{161}$ Race formed a crucial element in political arguments over education funding. Legislators often neglected or rejected funding for African American education in the state. During Dixon's tenure, he was one of the majority in the Democratic legislature that also rejected a bill to "encourage the industrial development" of African Americans, and recommended providing separate normal schools for Croatan Indians. ${ }^{162}$ Disagreements regarding equal access to education for nonwhite races persisted well after Dixon's time in the General Assembly, and became a central part of the later Progressive Era's political debates.

Though Dixon viewed the legislature as a tool for education reform and regulation, he feared government corruption and called for limits to state power. This became a foundational trait of his lifetime ideology. In this belief, he drew on the lessons of his college years and his childhood experiences during Reconstruction. Without such limitations, Dixon argued, "the tendency of all modern legislation is to ramify the functions of the government until all individual rights are absorbed." ${ }^{\text {163 }}$ At the Congressional Convention at Lenoir, he delivered a speech emphasizing the perils of government power run amok. Dixon "catalogued the infamies of Radical rule at Washington in the past," with a special focus on the events of Reconstruction, and "predicted the reign of a corrupt conscienceless money power that now threatened to

\footnotetext{
${ }^{161}$ Cook, Fire From the Flint, 60.

${ }^{162}$ Journal of the House of Representatives of the General Assembly of the State of North Carolina at the Session of 1885 (Raleigh: Ashe \& Gatling, State Printers and Binder, 1885), 167, 105.

163 “Mr. Dixon's Speech on the Obscene Literature Bill- 'The Individual vs. The State'," Raleigh Weekly Register (Raleigh, North Carolina), February 18, 1885.
} 
destroy the nation." "164 His vehement opposition to a bill prohibiting the sale of "obscene literature" also stemmed from his fear of too much government power. In a speech before the House of Representatives, Dixon denounced the Obscene Literature Bill. He maintained that supporting such a measure opposed "the most sacred article of my political creed," and required "disregarding every lesson upon the science of government that history and philosophy have taught me."165 The "buncombe" bill represented "the first step of a series of legislations leading to the slavery of the press and of thought."166 He perceived the proposed law as unenforceable, moralistic legislation aimed at restricting individual freedoms. "Not only would the freedom of the press be completely throttled," the young politician asserted, the bill would pave the way for an intellectual "age of darkness" caused by overenthusiastic censorship laws. ${ }^{167}$

In his speech opposing the censorship bill, Dixon warned the legislature that governments across the nation threatened the existence of individual liberty, an action he interpreted as having potentially disastrous results. This is the first time Dixon's works discuss socialism, individual rights, and civil revolution, themes that remained critical to his later ideology. "The State," Dixon insisted, "is continually arrogating to itself new power under the pretense of benefiting society," and treading "with sacrilegious foot soil

\footnotetext{
${ }^{164}$ Dixon, Southern Horizons, 175.

165 "Mr. Dixon's Speech on the Obscene Literature Bill- 'The Individual vs. The State'," Raleigh Weekly Register (Raleigh, North Carolina), February 18, 1885.

166 "Mr. Dixon's Speech on the Obscene Literature Bill- 'The Individual vs. The State'," Raleigh Weekly Register (Raleigh, North Carolina), February 18, 1885; "Obscene Literature," News and Observer (Raleigh, North Carolina), February 7, 1885.

167 "Mr. Dixon's Speech on the Obscene Literature Bill- 'The Individual vs. The State'," Raleigh Weekly Register (Raleigh, North Carolina), February 18, 1885.
} 
hitherto sacred to the individual."168 He viewed this "divine right of legislators" as "the greatest political superstition of modern times," an outdated practice "dropped from the head of a king to that of the legislator." Dixon predicted "but one end of these tendencies - governmental socialism, that condition of society in which the State is everything, man nothing, in which the State is supreme... the individual a vassal in the lowest and most galling sense." Failure to limit government restraints on individual rights, furthermore, would "drive society to the verge of another grand revolution, in the worldwide convulsions of which the great fourth estate will be born." Every additional legal restraint on the individual, in Dixon's perception, added another drop "to the madly swelling current of nihilism, communism, and socialism, which threatens to sweep from the earth the very foundation of modern civilization itself.",169

Dixon's experience debating the Obscene Literature bill prompted the conclusion that politics operated within a restrictive realm of money, interest groups, and personal relationships, rather than in the best interests of the people. "Reputation," rather, represented "the only thing that counts in politics." 170 Still, on the matter of the literature bill, he refused to "prostitute my powers as a tribune of the people," and announced a refusal to approve the measure. ${ }^{171}$ Though he opposed the censorship measure "on the ground that... it was a violation of the fundamental principles on which our Republic was

\footnotetext{
168 "Mr. Dixon's Speech on the Obscene Literature Bill-'The Individual vs. The State'," Raleigh Weekly Register (Raleigh, North Carolina), February 18, 1885.

169 “Mr. Dixon's Speech on the Obscene Literature Bill- 'The Individual vs. The State'," Raleigh Weekly Register (Raleigh, North Carolina), February 18, 1885; "Obscene Literature," News and Observer (Raleigh, North Carolina), February 7, 1885.

${ }^{170}$ Dixon, Southern Horizons, 184.

${ }^{171}$ Ibid.
} 
built, as well as a blow at progress," Dixon's speech did little to convince his fellow representatives. ${ }^{172}$ Instead, he was "attacked by the leaders of the churches and all the hypocrites who fawned on their power," and "roundly denounced by the majority."173 Dixon "came out of the conflict a sadder but wiser man" after the bill "passed by an overwhelming vote."174 The incident led young Dixon to believe special interests and partisan politics prohibited the government from making real change.

After his failure to prevent the Obscene Literature Bill, Dixon determined "to follow still further the unpopular line of action" and confront money interests in state politics. ${ }^{175}$ Enacting change, however, proved difficult. His efforts led to a confrontation with the Speaker of the House, which worked to further disillusion Dixon. "The State was catching the spirit from Washington," Dixon maintained, signaling the beginning of North Carolina's entry into "an era of soulless commercial expansion" and its entry into the global "race for unlimited concentrated wealth and power."176 This observation led him to introduce "A Bill to be Entitled an Act to Increase the Revenue of the State by a Tax on Gifts, Legacies, and Collateral Inheritances," which "aimed at reducing the power of concentrated wealth."177 Dixon's bill, he asserted would "equalize the burdens of taxation" and "increase the revenue of the state" by taxing "gifts," "legacies," and

\footnotetext{
${ }^{172}$ Dixon, Southern Horizons, 184-185.

${ }^{173}$ Ibid.

${ }^{174}$ Ibid.

${ }^{175}$ Ibid.

${ }^{176}$ Ibid.

${ }^{177}$ Ibid.
} 
"cultural inheritances." 178 The measure also included provisions for a standardized system of calculating taxes owed to the state in each county that was overseen by an appointed "Commissioner of State Revenue." " Though the House Finance committee suggested the bill's referral to the Senate, the Speaker of the House postponed discussion of the matter. ${ }^{180}$ Dixon viewed the Speaker's decision as evidence of special interests controlling the state legislature, as well as an abuse of the "despotic power" held by "the speaker of an American legislature." ${ }^{181}$ He attacked Speaker Holt, charging him with "laziness," "dullness," "stupidity," and partiality to the "favorites on the floor."182 The bill vote remained postponed, an action Dixon blamed on the influence of the Speaker's rich "associates," who viewed Dixon's bill as "the most dangerous thing yet introduced into a Southern Legislature, and that no discussion of it should be permitted on the floor of the House." $" 183$

Though Dixon achieved popularity among North Carolina's voters, he grew increasingly disillusioned with the political system. In a single legislative session, Dixon concluded that the corrupting influences of partisan interests prevented any real change at the legislative level. "Toward the end of my session," he wrote in his autobiography, "I

\footnotetext{
${ }^{178}$ Journal of the House of Representatives of the General Assembly of the State of North Carolina at the Session of 1885 (Raleigh: Ashe \& Gatling, State Printers and Binder, 1885), 287, 396.

179 "Equalization of Taxes: The Bill of Mr. Dixon, the Youngest Member of the Legislature," The Western Sentinel (Winston-Salem, North Carolina), February 26, 1885.

${ }^{180}$ Journal of the House of Representatives of the General Assembly of the State of North Carolina at the Session of 1885 (Raleigh: Ashe \& Gatling, State Printers and Binder, 1885), 649.

${ }^{181}$ Dixon, Southern Horizons, 184-185.

182 "Closing Scenes of the General Assembly," The Daily Journal (New Bern, North Carolina), March 17, 1885; Goldsboro Messenger (Goldsboro, North Carolina), March 16, 1885.

${ }^{183}$ Dixon, Southern Horizons, 184-185.
} 
realized that... I could have any office in the gift of the people... yet I had no sooner felt myself in the saddle than I began to realize a deep discontent with it all." Dixon realized that the price of political success, however, required him to "pander to the masses and be prepared always to submit to mob rule." He struggled with the notion "that I must prostitute my mind to reach and hold the higher power as a leader in politics." ${ }^{184}$ The tendency of politicians to abandon moral behavior in exchange for personal benefit, according to Dixon, made "the politician and the prostitute... the enemies of God. They are the non-moral developments of humanity." 185

The concept of immoral and self-interested public leaders helped fuel Dixon's increasing doubt about his career choice. In August 1886, he announced his withdrawal from the realm of politics in a statement reprinted in newspapers across the state. Dixon identified the singular reason for this departure as his determination "to live a conscientious and consistent Christian life," for he could not "be a successful politician and a successful Christian." 186 After leaving the capital "without the slightest desire to return," he briefly continued to practice law. ${ }^{187} \mathrm{He}$ found the same problems of corruption and lack of interest in public service within the legal system. To his dismay, most lawyers had not ethical quarrels with convicting innocent men, providing the clients compensated accordingly. Experiences in the courtroom led Dixon to compare the system of trial law to a crime, rather than an exercise in democratic justice. The system

\footnotetext{
${ }^{184}$ Dixon, Southern Horizons, 184-186.

${ }^{185}$ Ibid.

${ }^{186}$ Thomas Dixon, Jr., “To the People,” The Lenoir Topic (Lenoir, North Carolina), August 4, 1886.

${ }^{187}$ Dixon, Southern Horizons, 186.
} 
disproportionately benefitted the rich, who had more money to compensate their legal counsel. Lawyers' sole purpose, he argued, "is to sway their [the jury's] feelings not to do justice, but to force the acceptance of his view of the issue, the view of his client who had paid him a fee to make the appeal." "The more I thought it over," he recalled, "the sicker I got of trial courts," and, so, Dixon abandoned his legal practice. ${ }^{188}$ Following in the footsteps of his grandfather, father, and eldest brother, Thomas Dixon, Jr. decided to become a preacher. He joined the Baptist ministry, taking with him the intellectual foundations from college as well as a firm belief in reforming the corrupted government. This new career provided the next stage of his development.

${ }^{188}$ Dixon, Southern Horizons, 190. 


\section{$\underline{\text { Chapter Two }}$}

$\underline{\text { No Difference Between Secular and Divine (1886-1895) }}$

Thomas Dixon is often remembered in history as a blackguard who institutionalized Southern racism for the nation with his Reconstruction Trilogy produced in the first decade of the nineteenth century. Had he died in 1900, however, he would still have been an important figure in American cultural and intellectual history. Compared to Dixon's astonishingly successful early personal history, from his record at Wake Forest and Johns Hopkins, his odd flirtation with the New York stage, and his North Carolina political career, his ordination as a Baptist minister in 1886 would have seemed a step backward. Dixon turned this ministerial calling into the most extraordinary career move of his life. It led him first from a small church in Goldsboro, North Carolina, to a major congregation in the state capital and thence to a still grander venue in the heart of the Northeast in Boston, Massachusetts. Then, in 1889, he accepted the pulpit of a large church in New York City-he was only 23. Hardly even out of adolescence, Dixon used this pulpit to become one of the foremost ministers of the city, a notable political reformer, a scourge of Tammany Hall, and a phenomenal exemplar of Social Gospel radicalism. He won fame from the Atlantic Ocean to the Pacific. Both a talented speaker and a master of publicity, he lectured on the Chautauqua circuit in addition to serving his congregation. Newspapers relished reporting his lessons and activities, many reprinting his sermons in their entirety, and he published several of his lessons. Before turning thirty, then, Dixon had won national name recognition as minister, reformer, and public man. Simultaneously, he was also articulating new 
theories of the nation, national citizenship, and a host of related themes that would eventually carry him very far from the assumptions of these early ministerial years. Against the background of political unrest, economic dislocation, and cultural ferment, this chapter traces Dixon's own personal and intellectual trajectory as he acquired his first national reputation between 1886 and 1895 .

Disorder characterized every aspect of the Gilded Age in America-in the economy, politics, society, and intellectual assumptions. This turmoil, in turn, generated new trends and movements to address the myriad of transformations sweeping American life. Modernization touched nearly every aspect of American life. ${ }^{189}$ The nation's rapid industrialization after the Civil War led to sweeping changes in the realm of economics. Fierce conflicts between labor and capital were one result of post-war industrialization. By 1890 , the richest $1 \%$ of American families owned $51 \%$ of the wealth and property while the poorest $44 \%$ owned a mere $1.2 \%$. Businesses formed powerful corporations with influences that stretched state lines while laborers simultaneously organized like never before in U.S. history. Local trade unions joined newly formed national union

\footnotetext{
${ }^{189}$ For further reading on the socio-economic changes caused by post-Civil War industrialization and urbanization, see: Steven Cassedy, Connected: How Trains, Genes, Pineapples, Piano Keys, and a Few Disasters Transformed Americans at the Dawn of the Twentieth Century (Stanford: Stanford University Press, 2014); Michael Zakim and Gary J. Kornblith, eds. Capitalism Takes Command: The Transformation of Nineteenth-Century America (Chicago: University of Chicago Press, 2012); Jonathan Rees, Industrialization and the Transformation of American Life: A Brief Introduction (New York: Routledge, 2012); Jonathan Levy, Freaks of Fortune: The Emergence of Capitalism and Risk in America (Cambridge: Harvard University Press, 2012); Rosanne Currarino, The Labor Question in America: Economic Democracy in the Gilded Age (Urbana: University of Illinois Press, 2011); Walter Licht, Industrializing America: The Nineteenth Century (Baltimore: Johns Hopkins University Press, 1995); David E. Nye, Electrifying America: Social Meaning of a New Technology, 1880- 1940 (Cambridge: MIT Press, 1990); and David Hounshell, From the American System to Mass Production, 1800-1932 (Baltimore: Johns Hopkins University Press, 1985).
} 
groups, like the Knights of Labor and the American Federation of Labor. ${ }^{190}$ These organizations campaigned for labor reform, such as the eight-hour workday, federal regulation of corporations, and bank reform. ${ }^{191}$ The economy itself was far from stable, plagued by multiple panics in these decades. The 1893 panic and depression proved the most severe of these instances, exacerbating already existing class tensions. Approximately five hundred banks and fifteen thousand businesses failed, while hundreds of thousands of workers lost their jobs. Many laborers responded to their economic woes with violence, resulting in some 23,000 strikes from 1880-1900. ${ }^{192}$ “Coxey's Army,” a group of unemployed men, marched on Washington, Chicago experienced a violent railroad strike, and the Pennsylvania steel town of Homestead erupted into open warfare between strikers and private guards.

The 1880 s and 1890s were also characterized by drastic demographic shifts. Wage work assumed a new prominence in the U.S. economy, which, in turn, led to widespread urbanization as thousands of workers moved into cities seeking industrial positions. Increased immigration and rural-to-urban migration further remade the socio-

\footnotetext{
${ }^{190}$ More details on the Knights of Labor and/or the American Federation of Labor in the late-nineteenth century cab be found by consulting the following works: Leon Fink, Workingmen's Democracy: The Knights of Labor and American Politics (Urbana: University of Illinois Press, 1985); Kim Voss, The Making of American Exceptionalism: The Knights of Labor and Class Formation in the Nineteenth Century (Ithaca: Cornell University Press, 1994); Robert E. Weir, Beyond Labor's Veil: The Culture of the Knights of Labor (Philadelphia: Pennsylvania State University Press, 1996); Julie Greene, Pure and Simple Politics: The American Federation of Labor and Political Activism, 1881-1917 (New York: Cambridge University Press, 1998); Matthew Hild, Greenbackers, Knights of Labor, and Populists: Farmer-Labor Insurgency in the Late-Nineteenth Century South (Athens: University of Georgia Press, 2007); and Joseph Gerteis, Class and the Color Line: Interracial Class Coalition in the Knights of Labor and the Populist Movement (Durham: Duke University Press, 2007).

${ }^{191}$ Nancy Cohen, The Reconstruction of American Liberalism, 1865-1914 (Chapel Hill: University of North Carolina Press, 2002), 165-170.

${ }^{192}$ Heather Cox Richardson, The Death of Reconstruction: Race, Labor and Politics in the Post-Civil War South, 1865-1901 (Cambridge: Harvard University Press, 2002), 184-185.
} 
landscape of U.S. cities. Fifteen million immigrants entered the country between 1890 and 1914. Unlike many of the migrants already established in the U.S., many of these immigrants originated in Southern and Eastern Europe rather than the Northwestern part of the continent. Numbers for immigrants from Southern and Eastern European countries tripled both from 1880 to 1890 and again from 1890 to $1900 .{ }^{193}$ In addition, a "Southern diaspora" began at the end of the nineteenth century and stretching well into the twentieth century, in which thousands of black and white Southerners resettled throughout the nation. ${ }^{194}$ Like immigrants from foreign countries, these Southerners helped reshape the cultural and political landscape in the U.S. at the turn-of-the-century. In this exodus of more than one million white and 335,000 African American Southerners to the country's Northern commerce centers before 1900, Dixon represents one of almost 40,000 southern-born living in New York City. ${ }^{195}$

Politics reflected the same instability. The Democratic Party, which had enjoyed four years of dominance under Grover Cleveland as their first president since before the Civil War, lost the Presidency and both houses of Congress in $1888 .{ }^{196}$ The election, though, was not definitive, with Cleveland winning the popular vote and Harrison the

\footnotetext{
${ }^{193}$ Val Johnson, “'The Moral Aspects of Complex Problems': New York City Electoral Campaigns Against Vice and the Incorporation of Immigrants, 1890-1901," Journal of American Ethnic History 25, no. 2/3 (Spring 2006): 77-80.

${ }^{194}$ I have adopted this term from James M. Gregory's 2005 work on this subject, titled The Southern Diaspora: How the Great Migrations of Black and White Southerners Transformed America (Chapel Hill: University of North Carolina Press, 2005). Gregory argues "Southern migrants of both races became agents of change who used the opportunities of geography to alter the cultural and political landscape of the nation and all its regions," (7).

${ }^{195}$ Gregory, The Southern Diaspora, 12.

${ }^{196}$ Thomas Adams Upchurch, Legislating Racism: The Billion Dollar Congress and the Birth of Jim Crow (Lexington: University of Kentucky Press, 2004), 2-15.
} 
electoral vote, which further highlights the clouded nature of the country's politics. The the major parties experienced internal schisms of their own as third parties emerged. The growing popularity of the Farmer's Alliances and later Populists, combined with the growing socialist presence in American culture, represented a larger move by Americans looking to fundamental change. The "Populists," as they came to be called, had their roots in the long tradition of American agricultural and industrial labor advocacy. ${ }^{197}$ By the early-to-mid-1880s, populism was gaining popularity in the South and Mid-West, and it supporters called for the direct election of Senators, and for the dissolving of national banks to be replaced by local ones, among other reforms. In 1891, populists formed the People's Party, a national political entity with a platform seeking to add more silver into circulation, to lower the protective tariff, and add regulations for the transportation industries. $^{198}$

In the national legislature, questions about race, citizenship, and sectionalism permeated the first years of the 1890s. The Democratic and Republican parties were at

\footnotetext{
${ }^{197}$ Scholarly treatments of late-nineteenth century populist movements include: George McKenna, American Populism (New York: Putnam, 1974); Lawrence Goodwyn, Democratic Promise: The Populist Moment in America (New York: Oxford University Press, 1976); Steven Hahn, The Roots of Southern Populism: Yeoman Farmers and the Transformation of the Georgia Upcountry, 1850-1890 (New York: Oxford University Press, 1983); Robert C. McMath, American Populism: A Social History, 1877-1898 (New York: Hill and Wang, 1993); Michael Kazin, The Populist Persuasion: An American History (New York: Basic Books, 1995); Gene Clanton, Congressional Populism and the Crisis of the 1890s (Lawrence: University Press of Kansas, 1998); M. Elizabeth Sanders, Roots of Reform: Farmers, Workers, and the American State, 1877-1917 (Chicago: University of Chicago Press, 1999); Gerald H. Gaither, Blacks and the Populist Movement: Ballots and Bigotry in the New South (Tuscaloosa: University of Alabama Press, 2006); Joe Creech, Righteous Indignation: Religion and the Populist Revolution (Urbana: University of Illinois Press, 2006); Matthew Hild, Greenbackers, Knights of Labor, and Populists: Farmer-Labor Insurgency in the Late-Nineteenth Century (Athens: University of Georgia Press, 2007); Charles Postel, The Populist Vision (New York: Oxford University Press, 2007); Joseph Gerteis, Class and the Color Line: Interracial Class Coalition in the Knights of Labor and the Populist Movement (Durham: Duke University Press, 2007); Omar H. Ali, In the Lion's Mouth: Black Populism in the New South, 1886-1900 (Oxford: University Press of Mississippi, 2010); and James M. Beeby, ed., Populism in the South Revisited: New Interpretations and New Departures (Jackson: University Press of Mississippi, 2012).

${ }^{198}$ Postel, The Populist Vision, 103-133.
} 
odds over the issue of voting rights and the federal government's power to enforce the Fifteenth Amendment. After the end of Reconstruction, Southern states began suppressing African American voters through a combination of social harassment, legal measures, and violence, and the parties fought bitterly over the next course of action. The incoming Republican leaders viewed this as evidence that the work of Reconstruction remained unfinished, and focused on instituting social and political equality in the former Confederacy as the solution. Voting rights would give African Americans control over their local circumstances, Republican leaders argued, and could help the party gain strongholds in the South. ${ }^{199}$ Restoring black Southerners' voting rights required curbing suffrage restrictions in Southern states, so, from 1889 to 1891, the Fifty-first Congress attempted to remedy the "race problem" through federally enforcing the Fourteenth and Fifteenth Amendments in the Southern states. Republicans proposed a federal elections bill, also known as the "Lodge Bill," to regulate voting practices through the South. It would establish federal election inspectors at the request of a district's constituents. ${ }^{200}$ If the inspectors disagreed with the local government authorities regarding an election's outcome, federal courts would decide the results. The Lodge Bill passed the House of Representatives, but failed the Senate vote to become federal law.

Opposition to the Lodge Bill demonstrates the complexities of "the race question" in this period, and underscores the chaotic nature of American party politics. Neither of the two major parties could agree on the terms of "the race question" or its solution. Democrats labeled the Lodge Bill the "Force Bill," interpreting it as part of a larger

\footnotetext{
${ }^{199}$ Upchurch, Legislating Racism, 4.

${ }^{200}$ Richardson, The Death of Reconstruction, 201-209.
} 
partisan plan to construct a large central government under Republican power. ${ }^{201}$ They believed giving political power to the black masses of the South was a partisan strategy designed to strengthen Republicans' national base. Leaders in the Democratic Party argued Congress' plans to enforce universal manhood suffrage in the South violated states' rights and local sovereignty; each state possessed the right and responsibility to control access to the ballot. ${ }^{202}$ Further, not all Republicans in Congress saw voting discrimination in the South as a pressing issue. A faction of Republican congressmen favored focusing on economic issues, such as tariffs, the coinage of silver, and the regulation of trusts. ${ }^{203}$ This group viewed financial concerns as better political options, more relevant and less controversial amongst the constituency than voting equality in the South. While the Lodge Bill failed to pass, economic legislation received widespread congressional approval. Between 1888 and 1890, the Republican led-government swiftly legislated over previously contentious issues like the raising of the tariff, the coinage of silver, the regulation of trusts, and the provision for Civil War and military pensions. ${ }^{204}$

The late-nineteenth century wave of economic and political changes also resulted in a myriad of social issues and debates about how to solve them. Debates about the definition of citizenship, "whiteness," and the longterm impact of pluralism were one accompaniment to the increasingly diverse demography and economic circumstances of

\footnotetext{
${ }^{201}$ Upchurch, Legislating Racism, 2-15.

${ }^{202}$ Ibid.

${ }^{203}$ Ibid

${ }^{204}$ Ibid.
} 
late-nineteenth century U.S. cities. ${ }^{205}$ Race became critical to questions of citizenship and the definition of equality: Did citizenship guarantee voting rights? If so, which groups were eligible for citizenship? The American public, like Congress, disagreed over the definition of and solution to "the negro problem." Every facet of the issue provoked multiple opinions, including racism's correlation with the South, the meaning of equality, the nature of race tensions, and potential solutions. A myriad of positions formed in response, ranging from the idea that racism was a Southern trait in need of federal correction to the argument that no race problem existed at all. From the end of Reconstruction to the 1890 s, support for federally enforced equality dwindled. Some white Northern humanitarians began questioning the wisdom of the Reconstruction-era decision to bestow equal civil and political rights upon the freedmen, as well as the

\footnotetext{
${ }^{205}$ Further information on the evolving definitions of "whiteness" and "blackness" in the late-nineteenth and early-twentieth centuries, see: George M. Frederickson, The Black Image in the White Mind: The Debate on Afro-American Character and Destiny, 1817-1914, (New York: Harper and Row, 1971); Grace Elizabeth Hale, Making Whiteness: the Culture of Segregation in the South, 1890-1940 (New York: Pantheon Books, 1998); Valerie N. Babb, Whiteness Visible: The Meaning of Whiteness in American Literature, (New York: New York University Press, 1998); Matthew Frye Jacobson, Whiteness of a Different Color: European Immigrants and the Alchemy of Race (Cambridge: Harvard University Press, 1999); Mia Bay, The White Image in the Black Mind: African-American Ideas About White People, 18301925, (New York: Oxford University Press, 2000); Laura Browder, Slippery Characters: Ethnic Impersonators and American Identities (Chapel Hill: University of North Carolina Press, 2000); Todd Vogel, ReWriting White: Race, Class, and Cultural Capital in Nineteenth Century America (New Brunswick: Rutgers University Press, 2004); Anthony Harkins, Hillbilly: A Cultural History of an American Icon (New York: Oxford University Press, 2004); Michele Mitchell, Righteous Propagation: African Americans and the Politics of Racial Destiny after Reconstruction (Chapel Hill: University of North Carolina Press, 2004); Matt Wray, Not Quite White: White Trash and the Boundaries of Whiteness, (Durham: Duke University Press, 2006); Kate Dossett, Bridging Racial Divides: Black Nationalism, Feminism, and Integration in the United States, 1896-1935 (Gainesville: University Press of Florida, 2008); Jeannette Eileen Jones, In Search of Brightest Africa: Reimagining the Dark Continent in American Culture, 1884-1936 (Athens: University of Georgia Press, 2010); Khalil Gibran Muhammad, The Condemnation of Blackness: Race, Crime, and the Making of Modern Urban America (Cambridge: Harvard University Press, 2011); Jolie A. Sheffer, The Romance of Race: Incest, Miscegenation, and Multiculturalism in the United States, 1880-1930 (New Brunswick: Rutgers University Press, 2012); Julius Bailey, Race Patriotism: Protest and Print Culture in the A.M.E. Church (Knoxville, University of Tennessee Press, 2012); and Michael Wayne, Imagining Black America (New Haven: Yale University Press, 2014).
} 
wisdom of the Lodge Bill. Many humanitarians sought an alternative solution to installing racial equality and improving race relations. A program of education became one of the most popular proposals for remedying this problem. ${ }^{206}$

Increasing immigration complicated the national conversation about race and citizenship. Naturalization laws, as of 1870, stated "free white persons" and individuals "of the African race or of African descent" were eligible for citizenship. ${ }^{207}$ The classification of "Other" received no guarantee of naturalization upon arrival or birth. The wave of incoming immigrants, therefore, had the potential to reshape the nation's politics with their voting numbers. Defining which immigrants were "white" and "black," and which were "Other," however, became difficult. The hierarchical racial theories popular in this period differentiated between many different "white" groups, such as Anglo-Saxons, Celts, Italians, and Hebrews, leading to the legal issue of which peoples, exactly, were to be included in naturalization laws. ${ }^{208}$ As widespread migration reshaped national demographics, it created regionally specific race issues as these new arrivals entered the already-struggling labor market and varieties of social norms. ${ }^{209}$

\footnotetext{
${ }^{206}$ Richardson, The Death of Reconstruction, 183-224.

207 Jacobson, Whiteness of a Different Color, 74-76.

${ }^{208}$ For concise discussions of mid-to-late nineteenth century scientific definitions of whiteness, consult: Robert Wald Sussman, The Myth of Race: The Troubling Persistence of an Unscientific Idea (Harvard University Press, 2014); and Nell Irvin Painter, The History of White People (New York: W.W. Norton, 2010).

${ }^{209}$ For more on the relationship between migration, race, and labor, see: David R. Roediger, The Wages of Whiteness: Race and the Making of the American Working Class (New York: Verso, 1991); Melvyn Dubofsky, The State and Labor in Modern America (Chapel Hill: University of North Carolina Press, 1994); Michelle Brattain, The Politics of Whiteness: Race, Workers, and Culture in the Modern South (Princeton: Princeton University Press, 2001); James N. Gregory, The Southern Diaspora: How the Great Migrations of Black and White Southerners Transformed America (Chapel Hill: University of North Carolina Press, 2005); and David R. Roediger and Elizabeth D. Esch, The Production of Difference: Race and the Management of Labor in U.S. History (New York: Oxford University Press, 2012).
} 
Heavy immigration from Asia to the Western states, for instance, produced a reaction that led to legislation restricting future migration from Asia. The Northeastern states struggled with incorporating thousands of poverty-stricken migrants from Greece, Austria, Ireland, Hungary, Italy, Lithuania, Norway, Russia, and Turkey. Beyond these topics, the possible contributions of arriving immigrant groups to American socioeconomic structures remained unclear. Some U.S. born white Americans worried about the ability to assimilate, migrants' myriad of religions, ethnicities, and races into the current socio-economic structures. Nativists feared that Catholic immigrants, for instance, might allow religion a foothold in local government via sectarian schools, and that migrant communities might perpetuate radical ideas, such as anarchism or socialism, within the public ranks. Suggestions for immigration restriction often accompanied these connections. $^{210}$

Throughout the 1890 s, reformers offered a myriad of potential solutions to social inequality, racial tensions, political woes, and the changes in intellectual life of this new, modern period. Reformism manifested in multiple groups of citizens, including farmers, ministers, industrial factory workers, and intellectuals. Many of Dixon's white, middle and upper class peers and professors from his collegiate years, such as his instructors

\footnotetext{
${ }^{210}$ Further information on the late-nineteenth century debates over immigration, consult: Andrew Gyory, Closing the Gate: Race, Politics, and the Chinese Exclusion Act (Chapel Hill: University of North Carolina Press, 1998); David Reimers, Unwelcome Strangers: American Identity and the Turn Against Immigration (New York: Columbia University Press, 1999); Jacobson, Whiteness of a Different Color: European Immigrants and the Alchemy of Race (1999); Daniel J. Tichenor, Dividing Lines: The Politics of Immigration Control in America (Princeton: Princeton University Press, 2002); Roger Daniels, Guarding the Golden Door: American Immigration Policy and Immigrants Since 1882 (New York: Hill and Wang, 2004); Mae M. Ngai, Impossible Subjects: Illegal Aliens and the Making of Modern America (Princeton: Princeton University Press, 2005); and Aristide R. Zolberg, A Nation by Design: Immigration Policy in the Fashioning of America (Cambridge: Harvard University Press, 2009).
} 
Richard Ely and Herbert Baxter Adams, and classmate Woodrow Wilson, participated in these reform impulses, alongside women, African Americans, and immigrants. All their suggestions, however, depended on the active participation of individuals, communities, and governments. They helped form rural and urban working class political organizations, settlement houses, and urban immigrant associations, and lobbied for state and federal legislation to further address socio-economic problems. Reformers attacked the issues of political corruption, class conflict, and behavioral issues, as well as the meanings and limits of citizenship.

Many Americans proposed reforming portions of the social or economic system. Two notable examples are Henry George and Edward Bellamy. George's Progress and Poverty (1879) recommended a hefty single tax on land in order to end other taxes (such as those on production and labor) and fund public service projects. ${ }^{211}$ Edward Bellamy's Looking Backward's (1887) spawned a comparable public movement for a collectivist restructuring of the economy. The Nationalist movement of the late-1880s sought to apply his vision to reality. ${ }^{212}$ Socialism, especially the more formal version related to Marx and the First and Second International, was an active part of the history of

\footnotetext{
${ }^{211}$ Henry George, Progress and Poverty: An Inquiry into the Cause of Industrial Depressions and of Increase of Want with Increase of Wealth the Remedy (New York: J.W. Lovell, 1879).

${ }^{212}$ Edward Bellamy, Looking Backward: 2000-1887 (New York: Ticknor and Company, 1887) and The Programme of the Nationalists (Philadelphia: Bureau of Nationalist Literature, 1894); For more on the Nationalist movement, see Arthur Lipow, Authoritarian Socialism in America: Edward Bellamy and the Nationalist Movement (Berkeley: University of California Press, 1982); Claire Goldstene, "Edward Bellamy and the Reimagining of Equal Opportunity," in The Struggle for America's Promise, Equal Opportunity at the Dawn of Corporate Capital (Jackson: University of Mississippi Press, 2014), 104-121; Steven L. Piott, "Edward Bellamy: Utopian Socialist," in Americans in Dissent: Thirteen Influential Social Critics of the Nineteenth Century (London: Lexington Books, 2014), 211-230; and John L. Thomas, Alternative America: Henry George, Edward Bellamy, Henry Demarest Lloyd and the Adversary Tradition (New York: Belknap Press, 1983).
} 
American labor unions in the North. ${ }^{213}$ By the 1890 s, major northern labor organizations

like the Knights of Labor and the American Federation of Labor represented a large

portion of the country's workers, held major influence in government and, like the

populists, sought to reform the relationship between the country's workers and its

industrial capitalists.

\section{Reformers within American Protestantism offered their own compelling}

alternatives to the host of difficulties facing the nation. ${ }^{214}$ By the 1890 s, three different

213 "Socialism," in the late-nineteenth century, had varied meanings. Broadly, it could mean unselfishness or social cooperation, or an attitude or shared social spirit. Dixon subscribed to this first definition, viewing both the Social Gospel and the populist movement as ideologically socialist enterprises. The term could also mean a formal organized political movement, as well as be used in reference to a surging, idealistic movement of industrial workers and their allies. For more about socialism in this period, see: Donald Drew Egbert and Stow Persons, Socialism in American Life, Vol. 1 (Princeton: Princeton University Press, 1952); Denis W. Brogan, "The Eclipse of Socialism in the United States," University Review 1, no. 3 (Winter 1954/1955): 29-49; Walfred H. Peterson, "The Foreign Policy of the Socialist Party of America Before World War I," The Pacific Northwest Quarterly 65, no. 4 (October 1974): 176183; Peter Bellharz, Socialism and Modernity (Minneapolis: University of Minnesota Press, 2009); Marc Stears, Demanding Democracy: American Radicals in Search of a New Politics (Princeton: Princeton University Press, 2010); Doug Rossinow, "Partners for Progress? Liberals and Radicals in the Long Twentieth Century," in Making Sense of American Liberalism, edited by Jonathan Bell and Timothy Stanley (Urbana: University of Illinois Press, 2012): 17-37; Rhodri Jeffreys-Jones, The American Left and Its Impact on Politics and Society Since 1900 (Edinburgh: Edinburgh University Press, 2013); Ralph Young, Dissent: The History of an American Idea (New York: New York University Press, 2015); and Jacob Kramer, The New Freedom and the Radicals: Woodrow Wilson, Progressive Views of Radicalism, and the Origins of Repressive Tolerance (Philadelphia: Temple University Press, 2015).

${ }^{214}$ For scholarly discussions of late-nineteenth and early-twentieth century Protestant ideology and its many facets, see: Melanie Johnson-DeBaufre, Catherine Keller, and Elias Ortega-Aponte, eds., Common Goods: Economy, Ecology, and Political Theology (New York City: Fordham University, 2015); David Mislin, Saving Faith: Making Religious Pluralism an American Value at the Dawn of the Secular Age (Ithaca: Cornell University Press, 2015); Matthew Burton Bowman The Urban Pulpit: New York City and the Fate of Liberal Evangelicalism. New York: Oxford University Press, 2014); David Hollinger, After Cloven Tongues of Fire: Protestant Liberalism in Modern American History (Princeton: Princeton University Press, 2013); Anthony J. Carroll, Protestant Modernity: Weber, Secularization, and Protestantism (Scranton, Pennsylvania: University of Scranton Press, 2008); George Marsden, Fundamentalism in American Culture: The Shaping of Twentieth Century Evangelicalism, 1870-1925 (New York: Oxford University Press, 1980) and The Soul of the American University: From Protestant Establishment to Established Nonbelief (New York: Oxford University Press, 1994); James H. Moorhead, World Without End: Mainstream American Protestant Visions of the Last Things, 1880-1925

(Bloomington: Indiana University Press, 1999); Keith Harper, The Quality of Mercy: Southern Baptists and Social Christianity, 1890-1920 (Tuscaloosa: University of Alabama Press, 1996); and Charles C.

Cashdollar, The Transformation of Theology, 1830-1890: Positivism and Protestant Thought in Britain and America (Princeton: Princeton University Press, 1989). 
versions of "Social Christianity" competed for dominance in American life.

Conservatives believed individual Christians must be inspired to change their actions, and, thus, change society. The radical wing's ultimate goal was the institution of a socialist order. In between these two stances, the Social Gospel movement sought to apply the "teachings of Jesus and the total message of the Christian salvation to society, the economic life and social institutions... as well as to individuals.. ${ }^{215}$ Social Gospelers focused on the ethics of collective and individual responsibility, demanded the accommodation of science and secular social thought, and sought reformation of the church as well as society. ${ }^{216}$ In addition to eliminating poverty and vice, Social Gospel reformers crusaded against political corruption. New York moral reformers, for example, campaigned against Tammany Hall, the political machine notorious for corrupt operations.

Thomas Dixon's life assumes its larger significance amid these tumultuous times even as these very changes helped shape his own career. On October 6, 1886, at the old

\footnotetext{
${ }^{215}$ For more on the Social Gospel movement and late-nineteenth century Christian reformism, See Charles Howard Hopkins, The Rise of the Social Gospel in American Protestantism, 1865-1915 (New Haven: Yale University Press, 1940); Ronald C. White, Jr. and C. Howard Hopkins, The Social Gospel: Religion and Reform in Changing America (Philadelphia: Temple University Press, 1976); Paul Boyer, Urban Masses and Moral Order in America, 1820-1920 (Cambridge: Harvard University Press, 1978); Grant Wacker, "The Holy Spirit and the Spirit of the Age in American Protestantism, 1880-1910," The Journal of American History 72, no. 1 (June 1985); Donald K. Gorrell, The Age of Social Responsibility: The Social Gospel in the Progressive Era, 1900-1920 (Macon: Mercer University Press, 1988); Susan Curtis, A Consuming Faith: The Social Gospel and Modern American Culture (Baltimore: Johns Hopkins University Press, 1991); Ralph E. Luker, The Social Gospel in Black and White: American Racial Reform, 1885-1912 (Chapel Hill: University of North Carolina Press, 1991); Richard Wightman Fox, "The Culture of Liberal Protestant Progressivism, 1875-1925," The Journal of Interdisciplinary History 23, no. 3 (Winter 1993): 639-660; Paul T. Phillips, A Kingdom on Earth: Anglo-American Social Christianity, 1880-1940 (Philadelphia: Pennsylvania State University Press, 1996); and Mark A. Noll, God and Race in American Politics: A Short History (Princeton: Princeton University Press, 2008).

${ }^{216}$ Curtis, A Consuming Faith, 1-13.
} 
campus church at Wake Forest College, Dixon was ordained as a Baptist minister and began his ministerial career at a small Baptist church in Goldsboro, North Carolina. ${ }^{217}$ He garnered immediate fame through his early sermons, covered by the local newspapers, and soon the "talented young divine" assumed the pulpit at the Second Baptist Church in Raleigh. ${ }^{218}$ The praise continued and grew, thus The State Chronicle, a paper in Raleigh run by Dixon's friend from the Watauga Club, Josephus Daniels, labeled Dixon “a genius_-nothing more nothing less."219 The Raleigh Biblical Recorder praised Dixon's "full round nature of his own, uncontaminated by convention," and it categorized the young minister as "one of the incomparables... sprung full grown out of the head of the divinity." 220 His reputation as a riveting, enthusiastic, and powerful minister spread beyond North Carolina, and in November 1887 he accepted a position at the Dudley Street Church in Boston, Massachusetts. ${ }^{221}$ With this grander venue, Dixon's fame grew further, and in 1889 the twenty-six year old minister answered the call to lead the Twenty-Third Street Baptist Church in New York City. ${ }^{222}$

The Southern transplant took the city by storm, and his New York pulpit brought him national fame. One reviewer praised his sermons as “eloquent, harmonious,

\footnotetext{
217 “Baptist Men and Things," Christian Index, August 5, 1886; Cook, Fire From the Flint, 67.

218 "State News," Charlotte Home and Democrat, September 24, 1886; "State News," Charlotte Home and Democrat, August 6, 1886; "State News," Charlotte Home and Democrat, April 15, 1887.

219 “Rev. Thomas Dixon, Jr.," The State Chronicle, November 17, 1887.

${ }^{220}$ W.W. Tufts, “Rev. Thomas Dixon, Jr.," The Biblical Recorder (Raleigh, NC), November 18, 1888.

221 “Roxbury's Latest Pastor: Rev. Thomas Dixon's First Sermon in His New Capacity," Boston Daily Globe, December 5, 1887; "Religious Summary," Zion's Herald, November 30, 1887; Cook, Fire From the Flint, 68-70.

222 "Our Ministers and Churches: Miscellaneous Intelligence," Christian Secretary, April 10, 1889; "Communicated," The Charlotte Home and Democrat, April 4, 1889; Cook, Fire from the Flint, 73-74.
} 
powerful," and insisted that the manner of their delivery "stamp[ed] him as a genius."223

Another newspaper determined that "He will attain to a name that will ring over the continent and become as familiar as household words. $" 224$ Reporters characterized him as "A new star," "A Second Demosthenes," or "Second Henry Beecher," whose "platform king" oratory style "resembled Patrick Henry." 225 Hearers praised him not merely as a preacher, but "a scholar" and "a student," intelligent and up-to-date on his topics. ${ }^{226} \mathrm{He}$ simultaneously represented the "living embodiment of the convictions, ideals, and methods by which Christianity will yet triumph in the civilized world." ${ }^{227}$ Amid these praises, however, some critics scorned his "sensationalism."228 From his urban pulpit, Dixon's sermons were reprinted in various newspapers throughout the country, including the New York Times, the Chicago Daily Tribune, The Sun in Baltimore, and the Los Angeles Times. Local North Carolina papers, like The Progressive Farmer, the

\footnotetext{
223 “'Backbone': What Two Well Known North Carolina Editors Say to Rev. Thomas Dixon's Lecture," The Gold Leaf, October 23, 1890.

224 “Don’t Fail to Hear ‘Tom’ Dixon's Lecture,” The Gold Leaf, October 16, 1890.

225 "Don't Fail to Hear 'Tom' Dixon's Lecture," The Gold Leaf, October 16, 1890; "Religious News," The Progressive Farmer, July 22, 1890; "Dixon on 'Fools': The Brilliant New York Divine at DeGive's Opera House on Friday Evening," The Atlanta Constitution, January 24, 1894; “A Platform King," The Atlanta Constitution, April 29, 1892; "Rev. Thomas Dixon, Jr.," The Gold Leaf, October 23, 1890; Nym Crinkle, "Rev. Thomas Dixon: A Preacher Who Has Attracted Much Attention,” The Caucasian, May 12, 1892.

226 "Don't Fail to Hear 'Tom' Dixon's Lecture," The Gold Leaf, October 16, 1890; "Religious News," The Progressive Farmer, July 22, 1890; "Dixon on 'Fools': The Brilliant New York Divine at DeGive's Opera House on Friday Evening," The Atlanta Constitution, January 24, 1894; “A Platform King," The Atlanta Constitution, April 29, 1892; "Rev. Thomas Dixon, Jr.," The Gold Leaf, October 23, 1890; Nym Crinkle, "Rev. Thomas Dixon: A Preacher Who Has Attracted Much Attention," The Caucasian, May 12, 1892.

227 “Lecture at Tabernacle,” The Atlanta Constitution, July 17, 1898.

228 "The Savorless Salt: Rev. Thomas Dixon, Jr. on Corruption in the Church," The Caucasian, June 22, 1893; "Tired of a Sensationalist Preacher: The Rev. Thomas Dixon, Jr. Accedes a Request to Resign," Chicago Daily Tribune, March 11, 1895; “Is He a Fraud?” Durham Daily Globe, January 27, 1892.
} 
Henderson Gold Leaf, and The Caucasian. The young man also built his public image by lecturing at Chautauqua tours and other events.

While serving a minister, Dixon became a Social Gospel political and social reformer, and dedicated these years to revamping American society in order to alleviate the socio-economic problems of the arriving "modern" age. He viewed the entire postCivil War period as one of massive national alteration and growth, where "the problems of the present are the real problems which are to test the stability of the republic., ${ }^{229}$ His sermons demonstrate significant continuities between his collegiate ideals and ministerial reformism, and also reveal the influence of the Social Gospel movement and volatile labor politics of the period. Dixon continued advocating solutions similar to those viewed in his college years. Political corruption and partisan politics remained significant dangers to the nation, in his opinion, since "the political arena is where all the great questions of today and tomorrow must be fought and settled. ${ }^{230}$ He again identified sectional reconciliation, limited suffrage, and universal education as critical elements in battling corruption. The lessons of Dixon's moral philosophy and political economy classes are clear in his emphasis on the connections between Protestant ethics, politics, society, nature, and economics. To him, these were interlinked concepts, for "all social and economic questions have become political questions, and are religious."231 Dixon also viewed individual responsibility as key to national progress, stressing the

\footnotetext{
229 "Our Public Schools: Their Relation to the Development of Patriotism," The Wilson Advance (Wilson, NC), June 9, 1892.

230 “The Moral Import of the Farmer's Alliance," The Progressive Farmer, December 9, 1890.

${ }^{231}$ Ibid.
} 
importance of civic duty, modifying this idea to include all of secular culture. Science, art, knowledge, and democratic politics were "divine" institutions, "the avenues through which the divinity travels. ${ }^{, 232}$ To Dixon, no difference existed between spiritual and secular.

Dixon believed that leaders within the Christian community needed to join everyday people in serving an active civic role by directly addressing the problems of the new, capitalist order and seeking answers. Ministers would guide their congregations in political, as well as spiritual matters. In order to enable this new vision of Christian American society, Dixon participated in a variety of Protestant-led reform campaigns in New York City. In the late-nineteenth and early-twentieth centuries, Protestant revivals and church attendance in the city flourished, as did Dixon's career. The young minister attracted large crowds of hundreds, sometimes close to a thousand, of individuals to services at the Twenty-Third Street Baptist Church and larger services at Association Hall. ${ }^{233}$ Well-known Christian leaders, such as Lyman Abbott, Charles Henry Parkhurst, and Thomas De Witt Talmage spoke alongside Dixon during large-scale revivals at Cooper Union and the Academy of Music. ${ }^{234}$ Often, the revival event venues reached capacity, with up to five thousand attendees and even more people turned away. ${ }^{235}$ Working together, leaders from multiple Protestant denominations attempted to convert

\footnotetext{
232 "The Rev. Thomas Dixon on 'Intellectual and Social Aspect of Church Work'," Chicago Daily Tribune, February 11, 1891.

233 "New York City’s Shame,” New York Times, October 6, 1890.

234 "Revival Work Progressing: Audiences at Cooper Union and the Theatres Growing," New York Times, March 29, 1894.

235 "Lessons from Pulpits," New York Times, January 14, 1895; and "Thousands Turned Away: The Academy’s Doors Closed Long Before Dr. Talmage Begins,” New York Times, January 21, 1895.
} 
the masses of New York City and persuade them to assist in recreating their Social Gospel vision.

Battling corruption formed a seminal part of Dixon's reform agenda. Throughout the early 1890s, Dixon and other Social Gospel ministers succeeded in pushing a reformist agenda in New York City. The two political parties, in Dixon's formulation, were interested solely in election victory instead of the true needs of the people. ${ }^{236}$ Politicians' rejection of the "Golden Rule," to treat other individuals as you would want to be treated, endangered the nation with their immorality. ${ }^{237}$ Widespread corruption in the political, legal, and economic realms caused Americans to lose confidence in their nation, Dixon argued. ${ }^{238}$ To reformers, eliminating the pervasive presence of vices in the city, such as gambling and excessive drinking, was an essential element in battling political corruption. For Dixon, the saloon represented the "mightiest single political force in America," and "gamblers" ruled Washington. ${ }^{239}$ Corrupt courts and bureaucratic procedures, like licensing, "debauched" the public conscience and led to "a growing contempt for law, courts, judges, and juries."240 Dixon believed it necessary that

\footnotetext{
236 “Personals," Chicago Tribune, September 6, 1888.

237 “The Editor's Chair," The Caucasian, May 15, 1890; “Senator Ingalls Conversion," The Progressive Farmer, February 10, 1891; "Pulpit Criticism of Ingalls," Chicago Daily Tribune, February 2, 1891.

238 "Our So-Called Courts of Justice," The Progressive Farmer, February 3, 1891; "Personals," Chicago Daily Tribune, May 20, 1891; “Truth and Freedom: Rev. Mr. Dixon Shows How Christianity Abolished Slavery," The Caucasian, March 3, 1892; "Secular and Sacred: Rev. Thomas Dixon Holds All Legitimate Business as Sacred," The Caucasian, April 7, 1892.

${ }^{239}$ Rev. Thomas Dixon, Jr., "The Greatest Force in American Politics," The Washington Post, May 24, 1891; "Gambling in High Life," The Progressive Farmer, July 7, 1891.

240 "Truth and Freedom: Rev. Mr. Dixon Shows How Christianity Abolished Slavery," The Caucasian, March 3, 1892; "Our So-Called Courts of Justice," The Progressive Farmer, February 3, 1891; "Personals," Chicago Daily Tribune, May 20, 1891.
} 
Protestants "draw the sword of righteousness of Christ and defend its strongholds to save the people" and "free the race of this curse." ${ }^{241}$ He joined Presbyterian minister Charles Henry Parkhurst, and others, in an interdenominational effort to root out corruption in New York City through political engagement. ${ }^{242}$

One of Dixon's primary political targets in his sermons, Tammany Hall, the New York City political staple, represented the very embodiment of corruption to Protestant reformers. ${ }^{243}$ Its widespread political dominance, control of patronage, and corruption levels prevented society from moving toward God's plan by endorsing sin and vice. Since arriving in New York, Dixon spoke out against Tammany, arguing that the political corruption it perpetuated endangered not just New York, but the concept of national democracy. ${ }^{244}$ The "most powerful coterie of organized criminals that ever dominated the life of any people," according to Dixon, "is not simply a local disgrace," it is a

\footnotetext{
241 "The Evils of City Life: Dr. Dixon Points Out the Great Danger of Today," The Caucasian, April 20, 1893; "The City Life of Today," The Atlanta Constitution, April 21, 1893; "Gambling in High Life," The Progressive Farmer, July 7, 1891

242 "New York Preachers' Address on Municipal Vice," Our Day: A Record and Review of Current Reform 6 (July-December 1890): 370-373; Parkhurst occupied the pulpit at Manhattan's Madison Square Presbyterian Church; Jesse T. Todd, Jr., "Battling Satan in the City: Charles Henry Parkhurst and Municipal Redemption in Gilded Age New York," American Presbyterians 71, no. 4 (Winter 1993): 243; For more on Parkhurst and his reform efforts, see Warren Sloat, A Battle for the Soul of New York: Tammany Hall, Police Corruption, Vice, and Reverend Charles Parkhurst's Crusade Against The, 18921895 (Cooper Square Press, 2002).

${ }^{243}$ For more on Tammany Hall, see: Jerome Mushkat, Tammany: The Evolution of a Political Machine, 1789-1865 (Syracuse: Syracuse University Press, 1971); Edwin G. Burrows and Mike Wallace, Gotham: A History of New York City to 1898 (New York: Oxford Paperbacks, 2000); and Terry Golway, Machine Made: Tammany Hall and the Creation of Modern American Politics (New York: Liveright, 2014).

244 “A Southern Democrat on Tammany Hall," Los Angeles Times, July 11, 1892; “Tiger Flayed: A Pulpit Philippic Against Tammany," Los Angeles Times, June 27, 1892; "Here's Dixon Again: He Talks Politics Instead of Preaching the Word," The Atlanta Constitution, June 27, 1892; "Knives in Their Boots: Rev. Thomas Dixon, Jr.'s Characterization of Tammany," The Washington Post, June 27, 1892; “A Graphic Description of Tammany," Chicago Daily Tribune, June 29, 1892; “Tammany Shown Up: Another Heated Sermon by the Rev. Thomas Dixon, Jr.," Chicago Daily Tribune, June 27, 1892.
} 
national scourge." 245 The minister denounced Tammany leaders, such as Richard Croker and Commissioner Joseph Koch, labeling them "criminals" that "brought the city into the vilest political corruption." ${ }^{246}$ His political attacks led Koch to file libel charges against Dixon in 1892, making him the first minister in New York City to be indicted for such a charge. ${ }^{247}$ The charges were dismissed, and Dixon continued his mission to eliminate Tammany's power. ${ }^{248}$ Solutions to Tammany's influence lay in social reform and civic engagement. $^{249}$ To promote citizens' political participation, the minister organized a "civic union" to fight against Tammany Hall. ${ }^{250}$ As its President, Dixon sought to enlist citizens that believed "in purity and honesty in city government," to join his quest. ${ }^{251} \mathrm{He}$ also recommended they support "total separation of the municipal from the State and

245 "The Curtain Drops," The Progressive Farmer, August 15, 1893; "Thoughts Caused by the Scourge: the Rev. Thomas Dixon Has Something to Say About Tammany," Chicago Daily Tribune, September 26, 1892.

246 "Preacher Dixon Rampant: Speaks His Mind About Koch, Grant, Grady, and Higgins," New York Times, June 27, 1892; "Preacher Dixon at It Again: Talks Violently About Mr. Nicoll and Tammany Hall," New York Times, July 11, 1892; "Dixon Lets Go: He Sails Into Tammany Once More, Calls it an Organization of Criminals," Boston Daily Globe, July 11, 1892; "Renews His Attacks: Tammany Again Denounced by the Rev. Thomas Dixon, Jr.," Chicago Daily Tribune, July 11, 1892; "Croker Assailed From the Pulpit: The Rev. Thomas Dixon Bitterly Attacks the Tammany Boss," Chicago Daily Tribune, April 16, 1894; "Dixon on Croker," The Atlanta Constitution, April 18, 1894.

247 "Dixon Angry: Also Indicted for Saying Ill of Koch, First Minister in New York in His Position," Boston Daily Globe, June 25, 1892; "Pastor Dixon Defendant: Accused of Criminal Libel by Commissioner Koch," New York Times, June 3, 1892; and "Preacher Dixon in Court: Arrested on Complaint of Commissioner Koch, New York Times, June 4, 1892.

248 "The Outlook: General News," Christian Union, July 9, 1892; "No Case Against Mr. Dixon: The Indictment for Libel of Koch Dismissed," New York Times, July 1, 1892; and "Mr. Dixon Determined: From His Pulpit He Defies Tammany," Boston Daily Globe, June 27, 1892.

\footnotetext{
249 "Secular and Sacred: Rev. Thomas Dixon Holds All Legitimate Business as Sacred," The Caucasian, April 7, 1892.

250 "Rev. Thomas Dixon's New Party," The Caucasian, July 7, 1892; “Civic Union Platform Adopted: Tammany Hall and Its Methods in Politics Bitterly Arraigned," Chicago Daily Tribune, October 30, 1892.

251 “The Outlook," Christian Union, June 25, 1892.
} 
National elections," a measure he felt would prevent national partisan agendas from influencing the results of local campaigns. ${ }^{252}$ Dixon's municipal reform efforts intersected with those of Rev. Parkhurst, and were quite effective at drawing public attention to their cause. ${ }^{253}$

Throughout his early years as a minister, Dixon championed theological reform. He thought Christianity would have a direct impact on the new America's social and political development. He believed the new theology to be a crucial foundation for national advancement, and invested in Social Gospel ideals. Protestant ethics and the church would help solve the problems of modernization. The church, in his formulation, was "created for the purpose of saving the earth," and the way to rescue humanity was to strive for God's perfection to be recreated in the city. ${ }^{254}$ In order to achieve this vision of a reformed city and Christian nation, and to seize on the opportune moment for change, the Church and its leaders needed to become actively engaged with politics. ${ }^{255}$

Dixon believed the traditional Protestant church's failure to address the practical issues of the day represented one of many problems with conservative theology. In 1896, Dixon gathered his criticisms into a volume titled The Failure of Protestantism in New York and Its Causes. He argued that the church needed to adjust to modernity in order to

\footnotetext{
252 "The Outlook," Christian Union, June 25, 1892.

253 "Praise for Dr. Parkhurst: His Course Indorsed [sic] at a Great Mass Meeting," New York Times, May 27, 1892; “A Wave of Reform: Rev. Thomas Dixon, Jr. on Parkhurst's Crusade," The Caucasian, June 2, 1892.

254 “The Rev. Thomas Dixon on 'Intellectual and Social Aspect of Church Work'," Chicago Daily Tribune, February 11, 1891.

255 "The Future of Tammany_Shall the Worst Elements Rule Our Cities?" The Progressive Farmer, March 10, 1891.
} 
survive in the new nation and play a constructive role in its development. Traditionalism was outdated and flawed, and in an irrepressible conflict with the "School of Thought.",256 Dixon found every church divided into two classes, traditionalism and progress, and that the movement to compromise between them indicated an already-weakening, doomed conservatism. $^{257}$ Traditional ecclesiasticism, in his view, was the enemy of Christ and humanity. Thomas Dixon mercilessly lampooned traditionalists for assaulting science and setting "back the progress of the world for generations at a time." 258 Traditionalism had "repressed, crucified, and destroyed the prophets of truth in all ages," and "heaped upon the Church of Christ the infamy of a history of cruelty."259

Dixon lamented failures by the traditional church and its members to benevolently do God's work. A large portion of The Failure of Protestantism work is devoted to describing the terrible social conditions of New York's urban underbelly, hidden from the eyes of well-off churchgoers. ${ }^{260}$ Dixon maintained that the class divisions created by industrialization were exacerbated by the domination of the "strongest" churches by "fashion and pride and wealth, and social caste," for the sake of the "Bourgeois Aristocracy" membership rather than the benefit of the people. ${ }^{261}$ These divisions prevented the poor from becoming church members, and the attitudes of the current

\footnotetext{
256 “The Religious War-The Case of Professor Briggs-The Issues Involved," The Progressive Farmer, June 2, 1891.

257 “The Gambling Evil: Rev. Thomas Dixon Discusses It In His Prelude,” The Caucasian, March 30, 1893.

${ }^{258}$ Dixon, The Failure of Protestantism in New York and Its Causes, 65.

259 “Mr. Dixon Replies to Criticism,” New York Times, January 14, 1895.

${ }^{260}$ Boswell, "Unsheathing the Flaming Sword," 54.

${ }^{261}$ Dixon, The Failure of Protestantism in New York and Its Causes, 19-20.
} 
members drove away potential converts. The traditional church also "alienated the masses of the people and emptied the churches," by ignoring "the living questions of the day."262 The lack of action by nominal Christians thoroughly disgusted Dixon.

Throughout this work, he repeatedly called upon the members of the church to recognize the plight of the poor, whose "daily lot is a poverty that means hunger and cold, and nakedness and rags. ${ }^{263}$ The failure of the church to reach out to poverty-stricken masses would result in its decline. This decline had already begun with the "heathenism of materialism" throughout the cities. ${ }^{264}$ To regain control over urban areas, the church needed to "do one of two things — wake to the consciousness of her mission or die."265

Thomas Dixon argued that a new church needed to emerge to accompany the conditions of modernity. This new form of Protestant Christianity would embrace scientific theories and be self-critical of its own theological doctrine. He outlined this vision of a new Christianity in Living Problems in Religion and Social Science (1889), as well as in numerous sermons throughout the 1890s. This printed collection of sermons and public lectures confronted several theological issues Dixon thought required reform. He viewed the impending religious changes as necessary for national advancement. The "religion of the future," he claimed, would have four characteristics: "It will be vital; it

\footnotetext{
262 "Mr. Dixon Replies to Criticism," New York Times, January 14, 1895; "For the Sunday Papers: A Sensible Sermon by the Rev. Thomas Dixon of New York," Chicago Daily Tribune, June 29, 1890.

${ }^{263}$ Dixon, The Failure of Protestantism in New York and Its Causes, 28.

${ }^{264}$ Ibid, 112.

265 "Must Lead or Be Led: The Church's Alternative in the Present Great Crisis," The Gold Leaf, November $16,1893$.
} 
will be spiritual; it will be rational; it will be humanitarian."266 The new church would also be "liberal," Dixon insisted, "A mean, stingy man couldn't stay in it.",267

A functional Protestantism in Dixon's radical Social Gospel nation would also be structurally different. In his view, separate denominations of Protestant Christians hindered, rather than helped, the goals of the Church. He abhorred denominational bickering, and believed in "religious liberty, the right of every man to work God according to the dictates of his own conscience."268 A "division over stupid trifles" separated the Christian world from its mission to bring all of mankind salvation; "the smaller the difference, the fiercer the conflict. ${ }^{, 269}$ Denominationalism, in his opinion, prevented true Christian cooperation in the service of God and man. ${ }^{270}$ Catholics and Protestants needed to concentrate on fulfilling God's work through cooperation. ${ }^{271}$ This new Protestantism would be nondenominational, and "united always, standing shoulder to shoulder with a single grand thought ever before them, and moving toward that end in a solid phalanx."272

\footnotetext{
266 "The Growing Faith: Rev. Thomas Dixon on the Future of Christianity," The Caucasian, February 16, 1893. Italics are Dixon's.

267 "The Growing Faith: Rev. Thomas Dixon on the Future of Christianity," The Caucasian, February 16, 1893.

${ }^{268}$ Thomas Dixon, Jr., Living Problems in Religion and Social Science (New York: Charles T. Dillingham, 1889), 4.

${ }^{269}$ Thomas Dixon, Jr., The Failure of Protestantism in New York and its Causes (New York: Strauss \& Rehn Publishing Co., 1896), 54-56.

270 "God in Government, With a Prelude on the Mission of the Papal Delegate," The Caucasian, February 23, 1893.

${ }^{271}$ Ibid.

${ }^{272}$ Ibid.
} 
Dixon's new form of Christian thought and practice co-existed with scientific theories. A modern preacher's library, he maintained, consisted of "just as many books of science as books of philosophy and theology. ${ }^{, 273}$ Unlike his traditionalist counterparts, Dixon supported higher criticism of the Bible, evolutionism, and universalism, traits popularized in the late-nineteenth century by minister Henry Ward Beecher. ${ }^{274}$ Thomas Dixon supported Henry Ward Beecher as the "founder" and "prophet" of "the new school, the school that before the close of this century will drive out the old regime."275 Thomas Dixon, Jr.'s backing of Beecher reflected his firm belief that Christianity and science were crucially linked, "science is the revealer of God in nature."276 He viewed survival of the fittest as the "law of God."277 To Dixon, God inspired the discoveries of science and the achievements of the masters of literature, art, science, and mechanics. ${ }^{278}$ The divine presence in human history enabled "the sacredness of the secular," when "education, art, literature, science, and society, political and economic, are holy ground."279 To Dixon, the entirety of American society and culture would need to participate in the larger, divine project of reforming the nation.

\footnotetext{
273 "Our Christian Age," The Caucasian, March 31, 1892.

274 “Strong Criticism of Henry Ward Beecher," New York Herald, June 29, 1891.

275 "Mr. Dixon and Dr. Parkhurst, the Former Makes an Answer to his 'Old Fashioned' Clerical Critic," New York Times, April 15, 1895.

${ }^{276}$ Dixon, The Failure of Protestantism in New York and Its Causes, 65.

${ }^{277}$ Thomas Dixon, Jr., Dixon on Ingersoll: Ten Discourses Delivered in Association Hall, New York (New York: John B. Alden Publisher, 1892), 161.

278 "Progress Promise: Rev. Thomas Dixon on 'The Religion of Industry'," The Caucasian, November 30, 1893.

${ }^{279}$ Dixon, The Failure of Protestantism in New York and Its Causes, 65.
} 
God was tied not only to secular society, but to politics as well. According to Dixon, "if society is to be saved from anarchy," the state needed to act as "the outline of the Kingdom of God, being the only organ through which the people can act as one man in the pursuit of righteousness." ${ }^{280}$ The new religion of the modern era, in Dixon's eyes, needed to be involved in the most up-to-date politics of the period in order to help reconstruct God's kingdom on earth. ${ }^{281}$ Political involvement in endeavors favoring the common people, he argued, represented a "broader method" of reaching souls in the city. ${ }^{282}$ Representing the needs of the masses by creating a church that fought for those needs politically also justified the very existence of a church in the modern, industrial era. ${ }^{283}$ This new Protestantism would rid the cities of their evils, solve the social problem, and lead the nation to her divine destiny by forming a "socio-political power whose atmosphere will teach true citizenship." ${ }^{284}$ These educated, Christian citizens would provide the voting power needed to overturn corruption and set America on the path to her divine fate. ${ }^{285}$ Like many Social Gospelers, and the majority of his college influences, Dixon viewed the line between secular and political as permeable. In Dixon's

\footnotetext{
280 “Rev. Thos. Dixon Resigns,” New York Times, March 11, 1895.

281 "Church and Clergy," Chicago Daily Tribune, April 10, 1892.

282 "The Rev. Thomas Dixon on 'Intellectual and Social Aspect of Church Work'," Chicago Daily Tribune, February 11, 1891.

283 “The Saving Power: Rev. Thomas Dixon on the Need of a More Ernest Preaching," The Caucasian, June 29, 1893.

284 "The Future of Tammany-Shall the Worst Elements Rule Our Cities?" The Progressive Farmer, March 10, 1891.

${ }^{285}$ Rev. Thomas Dixon, Jr., "Christian Union,” The Homiletic Review: An International Monthly Magazine of Religious Thought, Sermonic Literature, and Discussion of Practical Issues 20, no. 6 (July-December 1890): 513-517.
} 
ideology, "politics is religion in action," and the duties of citizenship were a sacrament. ${ }^{286}$ "The man who deserts the ballot," he argued, "should be punished by civil law as a criminal" because "the crime committed is precisely the same in degree as that of the deserter." ${ }^{287}$ Christians needed to participate actively in changing the social and political worlds around them.

Dixon asserted that Protestant ministers held just as much responsibility for changing the nation, as did the voting masses. In order to create a politically informed congregation, Dixon preceded every sermon at the Twenty-Third Street Baptist Church with a "review of events" that discussed the main political issues of the week and later focused entirely political sermons. The decline of Protestantism's power in the city, according to Dixon, had provided newspapers an opportunity to seize control over public opinion. ${ }^{288}$ Print culture could provide the church the political sway it needed, if ministers learned "to preach to the press and through the press." 289 Determined to reach the souls of New York City, Dixon aimed "not to echo public sentiment, but to create it. ${ }^{, 290}$ He viewed himself as a "fisherman of men, and if they don't bite with one kind of

\footnotetext{
286 “Rev. Thos. Dixon Resigns,” New York Times, March 11, 1895.

287 "Personals," Chicago Tribune, March 11, 1891.

288 "For the Sunday Papers: A Sensible Sermon by the Rev. Thomas Dixon of New York," Chicago Daily Tribune, June 29, 1890.

289 “The Savorless Salt: Rev. Thomas Dixon, Jr. on Corruption in the Church,” The Caucasian, June 22, 1893.

290 "Pulpit Voices: Religious Thought and Progress in the United States," Los Angeles Times, October 31, 1897.
} 
bait I'll catch them with another." ${ }^{291}$ His sermons were one form of bait, but lectures, publications, and newspapers also became important elements in his strategy.

The political nature of Dixon's ministerial career led to intellectual clashes and debates with a variety of individuals. Colonel Robert G. Ingersoll, the famous defender of agnosticism, clashed with Dixon publicly in 1892. Throughout the 1880s and 1890s, Ingersoll questioned Protestantism's main tenets. ${ }^{292}$ On December 19, 1891, Colonel Ingersoll's "Christmas Sermon” appeared in the Evening Telegram. Ingersoll publicly pointed out the pagan origins of the holiday, while charging the institution of Christianity with bringing wars to the world. ${ }^{293}$ The colonel's criticisms evoked accusations of blasphemy from many Christians in New York, including Reverend Dr. J.M. Buckley and Reverend Thomas Dixon, Jr. A personal squabble ensued between Ingersoll and Dixon, resulting in published a series of ten sermons on the matter. ${ }^{294}$ These sermons meticulously indicate flaws in Ingersoll's arguments and refute them, all while simultaneously supporting an end to traditionalism, and a union of Christianity and science.

In refuting the conclusion of Ingersoll, Dixon emphasized the split between traditionalism and new theology. Despite Ingersoll's many statements focusing on the evils of Christianity, the atheist, Dixon argued, was actually acting out God's plan

\footnotetext{
291 “The Rev. Thomas Dixon on 'Intellectual and Social Aspect of Church Work'," Chicago Daily Tribune, February 11, 1891.

${ }^{292}$ For more on Ingersoll, see Susan Jacoby, The Great Agnostic: Robert Ingersoll and American Freethought (New Haven: Yale University Press, 2014).

${ }^{293}$ See Robert G. Ingersoll, The Great Ingersoll Controversy: Containing the Famous Christmas Sermon (New York: P. Eckler, 1894).

${ }^{294}$ See Dixon, Dixon on Ingersoll (1892).
} 
unknowingly by highlighting orthodox Protestantism's problems. ${ }^{295}$ God was using the colonel to help transform the church by stabbing "to the heart hundreds of superstitions and lies that have been no part of vital Christianity, and yet have posed as divine truth." 296 According to Dixon, Ingersoll 'sets up a man of straw called 'orthodoxy,' by which he means certain historic and traditional perversions of Christianity."297 The colonel's critiques, however, were inapplicable to Dixon's "Christianity of Christ," the spiritual basis of a modern Protestantism. ${ }^{298}$ Neither Ingersoll's agnosticism nor traditional Protestantism would survive into the twentieth century. ${ }^{299}$ As Dixon's vision of a new Christianity became a reality, the minister maintained, agnostic and atheistic opinions would be disproven as "unscientific." The advance of science, with its "gleaming two-edged sword," rose to "cut the dead bark off religion and cut the heart out of infidelity" by affirming God's existence in the secular world. ${ }^{300}$

The conservative element in the Baptist church disagreed with Dixon regarding pulpit politics. Many church leaders objected to the "new style of Christianity" as a whole, claiming it drove away potential converts. ${ }^{301}$ Politically charged ministerial messages, argued traditionalists, transformed the pulpit into a vulgar, violent, and overly

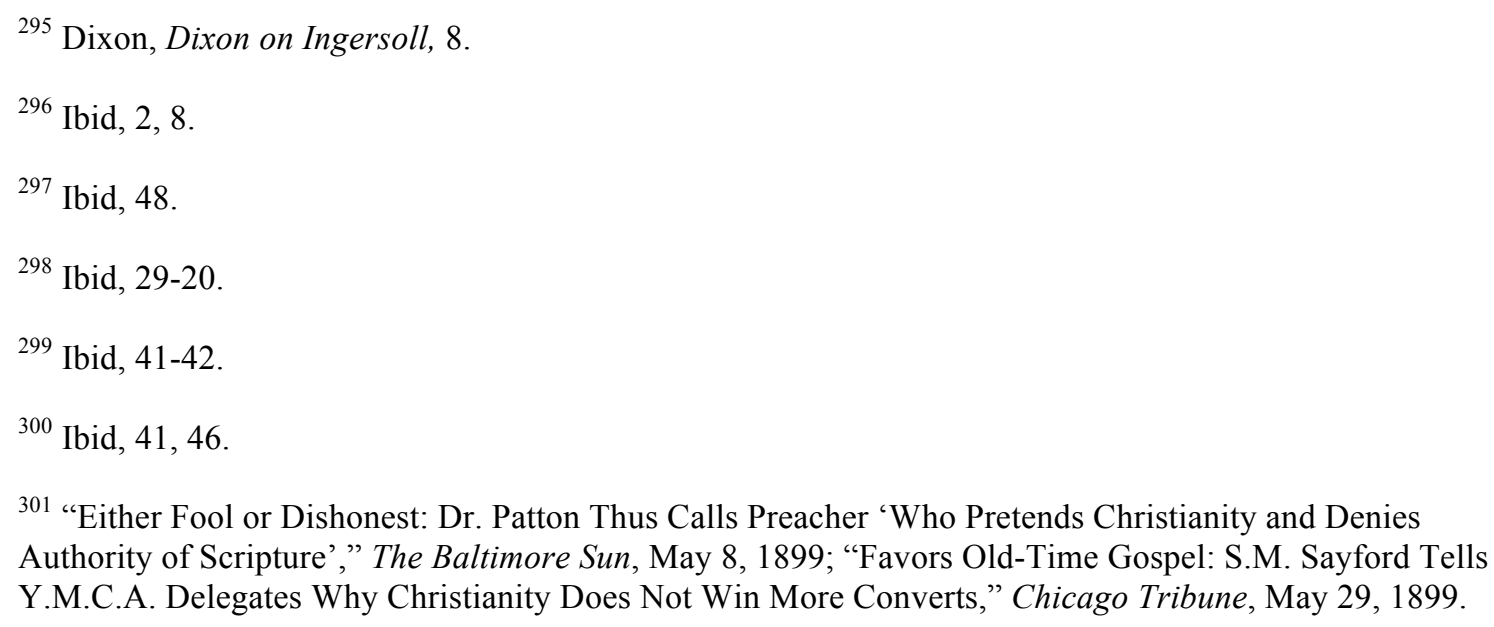


emotional place. ${ }^{302}$ The pulpit of this new Christianity, according to detractors, replaced the doctrine of justification by faith with political messages and partisanship. ${ }^{303}$ The business of the church, maintained traditionalists, did not include shaping politics. ${ }^{304}$ Protestant ministers who favored a nontraditional interpretation of Christianity complained of restrictions on their sermons, and insisted on the intermixture of secular and religious. ${ }^{305}$ Since traditionalists controlled the terms of acceptability, some politically zealous ministers found their efforts thwarted by trends in Protestantism. ${ }^{306}$

Disputes over the composition of sermons troubled Thomas Dixon, Jr., who desired a "free pulpit." ${ }^{307}$ The conservative element in Dixon's Baptist church did not always appreciate his political enthusiasm, resulting in "considerable friction" between Dixon and parts of the congregation. ${ }^{308}$ The trustees of his church grew "tired of a sensational preacher," and asked him to quit preaching on political issues. ${ }^{309}$ Dixon informed his conservative detractors that he "proposed to speak the truth, whether it was

\footnotetext{
302 "Mr. Dixon and Dr. Parkhurst, the Former Makes an Answer to his 'Old Fashioned' Clerical Critic," New York Times, April 15, 1895.

303 "Either Fool or Dishonest: Dr. Patton Thus Calls Preacher 'Who Pretends Christianity and Denies Authority of Scripture'," The Baltimore Sun, May 8, 1899.

304 "Politics Not for the Pulpit," The Atlanta Constitution, May 5, 1902.

305 “Rev. R. Heber Newton,” Boston Globe, April 15, 1900.

${ }^{306}$ Ibid.

307 “Rev. Thos. Dixon Resigns,” New York Times, March 11, 1895.

308 “The Rev. Thomas Dixon Will Resign: Sensational New York Preacher Too Radical for His Parishioners," Chicago Daily Tribune, March 10, 1895.

309 "Tired of a Sensationalist Preacher: The Rev. Thomas Dixon Jr. Accedes to a Request to Resign," Chicago Daily Tribune, March 11, 1895; "The Rev. Thomas Dixon Will Resign: Sensational New York Preacher Too Radical for His Parishioners," Chicago Daily Tribune, March 10, 1895.
} 
sensational or not... they would have to make up their minds to stand it."310 After about a year, this clash of agendas forced Dixon to resign from the Twenty-Third Street Baptist Church in 1895, after receiving pressure from the Board of Trustees. ${ }^{311}$ The church cited financial reasons for the reverend's departure: Dixon wanted too much money for Sunday sermons. ${ }^{312}$ In his resignation, Dixon argued "the machinery of a strict Baptist Church" hindered his efforts to reach the masses of New York City. ${ }^{313}$ He attempted to spread his thoughts to the people through lectures and novels, instead.

As Dixon worked with the classical categories and typical issues of the Social Gospel crusaders, he was also evolving, simultaneously, larger notions about where elements of the modern nation fit, or failed to fit, together. This involved his developing ideas regarding regional relationships, nationality, citizenship, and the foundations of the nation itself. His sermons demonstrate the influence of "patriotic millennialism," or the belief that God preordained the United States to prosper as a global symbol of Christian civilization, contributed to Dixon's reformism and ideology. ${ }^{314}$ He believed that divine will indicated the United States would prosper in the new, modern age. To Dixon, divine

\footnotetext{
310 "The Rev. Thomas Dixon Will Resign: Sensational New York Preacher Too Radical for His Parishioners," Chicago Daily Tribune, March 10, 1895.

311 "Rev. Thos. Dixon Resigns," New York Times, March 11, 1895; "Tired of a Sensationalist Preacher: The Rev. Thomas Dixon Jr. Accedes to a Request to Resign," Chicago Daily Tribune, March 11, 1895; "Another Independent Preacher: Rev. Thomas Dixon, Jr., Will Resign to Start a Church of His Own," The Washington Post, March 11, 1895.

312 "Tired of a Sensationalist Preacher: The Rev. Thomas Dixon Jr. Accedes to a Request to Resign," Chicago Daily Tribune, March 11, 1895.

313 "Rev. Thos. Dixon Resigns: He Quits the Twenty-Third Street Baptist Church May 1 to Organize an Independent One,” New York Times, March 11, 1895.

314 Joe Creech coined the term "patriotic millennialism" in Righteous Indignation: Religion and the Populist Revolution (Chicago: University of Illinois Press, 2006), 28.
} 
law and history were interrelated, and "every nation's history is a revelation of God unto men." "315 "God has called you to teach the nations of this world something real," he told his congregation, "God called you to lead them in the development of a world's liberties... to lead the world in citizen kingship in the great role of fraternal equality and fraternal manhood." 316 He predicted the creation of an American-led, Anglo-Saxon "international brotherhood," ruled by "justice and love," which would control the world's affairs. ${ }^{317}$ Fulfilling divine destiny required the creation of a new, unified country, distinct from its pre- Civil War incarnation, Dixon asserted, as well as improving its socio-economic circumstances through various reforms.

Dixon argued that the socio-economic conditions and political climate of the early-1890s complicated the construction of his ideal America and posed significant dangers to national power and progress. He used his pulpit to address the "problems of the age," which, included: the "Labor Question," or problems between capital and labor; the "Southern Problem," or how to reconcile the sections; and the "Race Problem," or how to alleviate racial tensions. Only by addressing these issues could America fulfill its divine destiny to "lead the march of the new civilization of the twentieth century." 318 Dixon believed that a combination of individual, government, and community actions could solve the nation's problems and assist in the construction of a strong national identity. This cooperation was essential to his vision. Without this all-around reform

\footnotetext{
315 "God in Government, With a Prelude on the Mission of the Papal Delegate," The Caucasian, February $23,1893$.

${ }^{316}$ Ibid.

${ }^{317}$ Ibid.

318 "The Need of a More Vigorous Americanism," The Progressive Farmer, April 21, 1891.
} 
effort, in Dixon's formulation, sectionalism, racial animosities, labor problems, and corruption would persist. To Dixon, the continuance of these issues prevented America from fulfilling its destiny to "lead the forces of freedom for the nations of the earth."319 "This work," he insisted, "can only be done in the assertion of a distinct nationality," and that identity could come to fruition only through concerted efforts to solve the country's current socio-economic problems. ${ }^{320}$

While in Boston and New York, Dixon's sermons turned to the "The Southern Question" or "the problem of... how can sectionalism be eliminated from our national life, social, economic, and political." ${ }^{321}$ Regional distinctions, Dixon argued, should not prevent the creation of a united American national identity. The lingering sectionalism of the Civil War period hindered the nation from embarking on its path to progress. He connected sectionalism with partisan political corruption and media bias. Sectionalism stemmed from two main sources in this formulation: mutual misunderstanding between the regions and the legacy of Reconstruction politics. ${ }^{322}$ Misunderstandings between North and South resulted from a variety of influences, including biased newspapers, "knaves," "cranks," and partisan politicians, each group with its own motives for keeping regional tensions in tact. ${ }^{323}$ By exploiting sectionalism, Dixon asserted, partisan minority groups "made progress impossible because they have made issues of memories, and

319 "Foreign Colonies in America," The Progressive Farmer, June 30, 1891.

${ }^{320}$ Ibid.

321 “The Southern Question: Rev. Thomas Dixon, Jr. Speaks on the Question in Boston,” The Watauga Democrat, May 15, 1889.

${ }^{322}$ Ibid.

${ }^{323}$ Ibid. 
marshaled the hosts of the living to fight the hopes of the dead." "324 As a result, "the Northern people view the South through a mirage of misrepresentation, exaggeration, and falsehood." 325 The North's failure to grasp the impact of Reconstruction politics on the South, according to Dixon, complicated "the fog of sectional animosity." 326 He thought Northerners misinterpreted the era as one of sheer racism and hate on the part of white Southerners, rather than understanding the effects of uneducated African American voters. Allowing newly freed slaves voting rights and participation in the South's postCivil War government, he argued, led to poorly managed state and local governments. ${ }^{327}$ Southern whites had united only to overturn Reconstruction conditions, saving the region from economic and political ruin. ${ }^{328}$ Further, Southerners possessed no desire to fight the battles of the Civil War. "The Southern man," Dixon insisted, "fervently thanks God that his country is freed from the curse of slavery.",329

The "race problem," in Dixon's view, created and reinforced social, political, and economic divisions that prevented the formation of a singular national identity. The idea of a specifically Southern race problem fueled sectional divisions and partisan agendas, which prevented the regions from uniting behind a singular patriotism. Dixon defined

\footnotetext{
324 "Sectionalism and the Farmer's Alliance," The Progressive Farmer, December 23, 1890.

325 "The Southern Question: By Southern Men, I-When Will the Negro Be Free?" Christian Union, May 22,1890 .

326 Ibid.

327 “The Southern Question: Rev. Thomas Dixon, Jr. Speaks on the Question in Boston,” The Watauga Democrat, May 15, 1889.

328 Ibid.

329 “Sectionalism and the Farmer's Alliance," The Progressive Farmer, December 23, 1890.
} 
"the race problem" as larger patterns of racial and ethnic tensions between different groups throughout the nation. "There is race prejudice in the South, plenty of it," he admitted, but "the North is almost as bad." ${ }^{330}$ Each region possessed its own version of the South's prejudice, in his formulation. Dixon believed the idea of "the race problem in the South," as a concept, resulted from partisan political aims, and regional differences in the definition of democracy. Republican Congressmen, he argued, were stoking Civil War era sectional hatreds in order to achieve better political representation in the South and, in the process, undoing Southern progress since the war's end. Dixon viewed the Lodge Bill as a threat to national reconciliation that would "rouse race bitterness, hatred and suspicions," giving "new life to a traditionalism and bourbonism in the South that are going to pieces" and "an indefinite lease of life to the old race cries of the white and black demagogues." 331 He traced Northerners' sympathies for African Americans to two politically driven sources, "either the tears that flow from the weakening eyes of old men," and "the crocodile tears of younger demagogues who hope to move the populace by their brine." ${ }^{332}$

Another source of Northern support for universal male suffrage, Dixon maintained, lay in regional definitions of democracy. Democracy in the North "did not mean what it does in North Carolina," he wrote to a Raleigh paper. Instead of representing "the vast mass of the wealth, virtue, and intelligence of the community,"

\footnotetext{
330 "The Southern Question: By Southern Men, I-When Will the Negro Be Free?" Christian Union, May 22,1890 .

331 “The Negro and the Lodge Bill," The Progressive Farmer, January 27, 1891.

${ }^{332}$ Ibid.
} 
hence the voter restrictions in the South, Dixon argued, democracy in the Northern states, "as a rule it means just the opposite - it means the riff-raff, rag-tag, and bob tail of creation" participated in the electoral process. ${ }^{333}$ He challenged the idea of excessive voter suppression in the South, arguing that Northern states' suffrage laws enacted parallel restrictions on the few groups it considered unfit for suffrage. ${ }^{334}$ Furthermore, "the right to vote is not a right," he insisted, but a "power," "trust," and "privilege" in "the governing function of the community" that required "certain qualifications.",335 Most African Americans, in Dixon's opinion, lacked the education needed to qualify for suffrage. Southern states" "interference with the negro vote," he maintained, assured that uneducated voters failed to disproportionately influence politics. ${ }^{336}$

Dixon identified heightened levels of immigration in the late-nineteenth century as another part of the national "race problem." Recent European migrants threatened to undermine nationalism by refusing to assimilate. Too many foreign communities refused to teach their students in English, Dixon concluded. ${ }^{337}$ The influence of these "foreign colonies in America" led to their control of "whole sections of our Western states.",338 $\mathrm{He}$ demanded that immigrants "become American citizens in the real sense," by dropping

\footnotetext{
333 Thomas Dixon, “The Yankees: Rambling Notes About Boston and Boston Ways," State Chronicle (Raleigh), December 29, 1887.

334 "The Southern Question: By Southern Men, I-When Will the Negro Be Free?" Christian Union, May 22,1890 .

${ }^{335}$ Ibid.

336 “The Negro and the Lodge Bill," The Progressive Farmer, January 27, 1891.

337 "Foreign Colonies in America," The Progressive Farmer, June 30, 1891.

${ }^{338}$ Ibid.
} 
their Old World prejudices and joining "in the work of the industrial, social and intellectual development of the great Republic," as had previous generations of European migrants. ${ }^{339}$ The increasing amounts of suffrage-eligible immigrants, Dixon argued, strengthened partisanship further, since he deemed the majority of migrants uneducated and easily manipulated by politicians. The thousands of migrants arriving monthly, he maintained, also exacerbated domestic labor problems and transferred anarchistic ideas to the American population. ${ }^{340}$ The socio-economic divisions exacerbated by the race problem, in Dixon's opinion, both masked and exacerbated the nation's relevant, contemporary problems. Debates over immigration were often rooted in race and citizenship, while "the real question before the American people," he insisted, "is not a question of a bit of paper called a ballot... but of bread." ${ }^{, 341}$

Dixon advocated federal legislation addressing the "mighty, living problems" of the age, such as "finance, taxation, education, and social and economic development.",342 In addition to federal workplace regulations and collective ownership of communication and transportation systems, he advocated a three-prong "national policy" containing the “cardinal principles" of immigration regulation, altering naturalization laws, and a patriotic system of education. Each of these points, he asserted, would help the country

\footnotetext{
339 "The Need of a More Vigorous Americanism," The Progressive Farmer, April 21, 1891.Italics are Dixon's.

340 "Ethics of Wealth: Rev. Thomas Dixon on the Lessons of Jay Gould's Life," The York Daily (York, PA), December 26, 1892.

341 “The Southern Question: By Southern Men, I-When Will the Negro Be Free?” Christian Union, May 22,1890 .

342 "The Negro and the Lodge Bill," The Progressive Farmer, January 27, 1891.
} 
prosper in the conditions of the modern age, by helping to "purify" the ballot. ${ }^{343}$ Dixon advocated restricting immigration, especially from Southern and Eastern Europe. The late-nineteenth century wave of immigrants originating in Eastern and Southern Europe posed more of a threat to the nation than Chinese immigration, he argued, because they failed to assimilate. 344 "I have no sympathy with KnowNothingism, Dixon insisted, "but I do believe in patriotism," and "our salvation depends upon our ability to assimilate the foreign element which enters our national life."345 Like many other Americans of the period, he differentiated between the "old" migrants of previous generations and the "new" wave of arrivals. "This nation was built by immigrants," he proclaimed, "but it was not built by the class of immigrants that are now pouring in on us from the prisons and slums of the Old World."346 Dixon recommended that migrants pay a one hundred dollar entrance fee, attend English-language schools, and undergo a literacy test requirements before being allowed to vote. ${ }^{347}$ He also demanded that the federal government amend naturalization laws to eliminate the current "state of chaos" where men who were not citizens managed to vote in elections.

A mandatory system of patriotic public education formed another element of Dixon's proposed national policy. Dixon argued that time and education offered the only

\footnotetext{
343 “Foreign Colonies in America," The Progressive Farmer, June 30, 1891.

344 “The Need of a More Vigorous Americanism,” The Progressive Farmer, April 21, 1891.

345 "Foreign Colonies in America," The Progressive Farmer, June 30, 1891.

346 “The Ethics of Wealth: Rev. Thomas Dixon on the Lessons of Jay Gould's Life," The York Daily (York, PA), December 26, 1892.

347 Ibid.
} 
solutions to racial tensions. ${ }^{348}$ He identified education as "the fundamental basis of a moral life," and, thus, a necessary prerequisite for voting rights. ${ }^{349} \mathrm{He}$ also equated knowledge with freedom, maintaining that "to inculcate truth, is to make men free," and "the freedom of the race, the freedom of the world, is the goal of our nation." "350 To illustrate the importance of education, Dixon used the example of poor whites and African Americans in the Southern states, in communities where "the average morality is so low that is falls beyond the power of statistics to illustrate," and "the disregard of the marriage relation is something appalling."351 Educational institutions provided the "only one bright spot in all the darkness of this sad picture," and the communities around these institutions lacked the moral failings of their non-educated counterparts. "352 "In the public school only," he argued, "will we find the solution for the Indian problem and the Negro problem of the South." 353 To enable racial equality in voting rights, Dixon promoted a "threefold" education_-"education of the head, the hand, the heart," over a period of

\footnotetext{
348 "The Southern Question: By Southern Men, I-When Will the Negro Be Free?" Christian Union, May 22, 1890; "The Negro Does Vote: Southern People Do Not Suppress the Black Man, Says Mr. Dixon," The Atlanta Constitution, April 12, 1890; "Mr. Cable's Ideas: They Differ Somewhat from Those of Rev. Thomas Dixon," Boston Daily Globe, December 14, 1890.

349 "Our Public Schools: Their Relation to the Development of Patriotism," The Wilson Advance, June 9, 1892.

${ }^{350}$ Ibid.

${ }^{351}$ Ibid.

${ }^{352}$ Ibid.

${ }^{353}$ Ibid.
} 
time, resulting in current non-white voters eventually being capable of selfgovernment. $^{354}$

Dixon's ideal public school represented "the furnace in which the amalgam" of a national identity could be formed. ${ }^{355}$ He demanded widespread recognition of "the fact that education is the foundation of this nation's life."356 Dixon's believed public schools were "the heart of the nation," and possessed the potential to either "build and enrich, or poison" the nation's future citizens. ${ }^{357}$ "The time has come," he told his congregation, "when, as a nation, we must require the coming citizens of the nation to prepare themselves for the exercises of the privileges of citizenship." ${ }^{358}$ Dixon intended for public schools to act as an arbiter of patriotic identity. By "teaching the first lessons of patriotism," he maintained, to "the children of all these conflicting creeds and races," "every child heart may be made a patriot-hero, touched by the fire of truth and freedom.",359 In Dixon's ideal public curriculum, "the rising generation" would be "educated in the language of the Constitution," "taught the spirit of the American nation," instructed in American history, and taught "the meaning of American citizenship.",360

\footnotetext{
354 “The Southern Question: By Southern Men, I-When Will the Negro Be Free?" Christian Union, May 22, 1890.

355 "Our Public Schools: Their Relation and to the Development of Patriotism," The Wilson Advance, June $9,1892$.

356 "Foreign Colonies in America," The Progressive Farmer, June 30, 1891.

357 "Our Public Schools: Their Relation and to the Development of Patriotism," The Wilson Advance, June 9, 1892.

358 "Foreign Colonies in America," The Progressive Farmer, June 30, 1891.

359 "Our Public Schools: Their Relation and to the Development of Patriotism," The Wilson Advance, June $9,1892$.

360 "Foreign Colonies in America," The Progressive Farmer, June 30, 1891.
} 
The goal of this patriotic education was to show students "that the American nation stands for something in the history of the world. That we are to lead, not be led. That we are to originate, not imitate." ${ }^{\prime 361}$ After being instructed in Dixon's version of the fineries of Americanism, students would be prepared to be effective and productive future citizens.

To Dixon, social and political reform seemed indispensable. Twenty-five years under the "real rulers" of the nation, "corporate directors, bank officers, railroad presidents, and mining kings," had rendered Washington D.C. useless. ${ }^{362}$ "Wall Street," Dixon maintained, "is the center of government in America."363 Money permeated partisan politics. The time had come, he believed, for the reign of corporations to end. ${ }^{364}$ As the "strategic point of America," New York City offered Dixon opportunities to influence society by preaching to a substantial portion of its voters. ${ }^{365}$ Reforming the city was crucial for national progress, since "the redeemed city" would form the basis of the

\footnotetext{
361 "Our Public Schools: Their Relation and to the Development of Patriotism," The Wilson Advance, June $9,1892$.

362 "The Fight to the Death: As Tom Dixon Sees the Future Storm," The Caucasian, April 23, 1891; "Mr. Dixon's Warning: The Millions and the Millionaires Battle Array," The Gold Leaf, April 30, 1891; "The Future of Corporations-The Coming Great Battle," The Progressive Farmer, May 5, 1891.

363 "The Power of Money: Rev. Thomas Dixon's Sermon on the Almighty Dollar," The Caucasian, July 6, 1893; "The Love of Money: Rev. Thomas Dixon's Second Sermon on Money and Christianity," The Caucasian, July 13, 1893; "Love of Money: Rev. Thomas Dixon's Sermon on the Subject," The Gold Leaf, July 20, 1893; "The Power of Money: Thomas Dixon's Sermon on the Almighty Dollar," The Gold Leaf, July 13, 1893.

364 "The Fight to the Death: As Tom Dixon Sees the Future Storm," The Caucasian, April 23, 1891; "Mr. Dixon's Warning: The Millions and the Millionaires Battle Array," The Gold Leaf, April 30, 1891; "The Future of Corporations-The Coming Great Battle," The Progressive Farmer, May 5, 1891; "The Era of Transition: Signs that Signify the Approach of a New Social Order," The Gold Leaf, November 2, 1893.

365 “Rev. Thomas Dixon, Jr.," The Gold Leaf, October 23, 1890.
} 
"new," "redeemed" nation. ${ }^{366}$ None of these reforms, however, were possible without individual action. Dixon believed, citizens needed to play a crucial role in the fight against political corruption, and that individual activism provided the foundation of successful reform efforts. ${ }^{367}$ Each American bore a responsibility to the nation, he argued, to strive to be educated and engaged (formally if eligible for suffrage and through patriotic-minded behavior on the part of non-voters) participants in the construction of his vision. Dixon implored his congregations to abandon political apathy. ${ }^{368}$ The current corrupted political system, in Dixon's experience, did not put the nation first: they put voters first. ${ }^{369}$ Without their political participation, partisan agendas and the influence of wealth would continue to dominate the national consciousness, paralyzing the nation from its path of progress. ${ }^{370}$ In the years following his resignation from the Baptist fold, however, his faith in the possibilities of the people as reformers wavered.

\footnotetext{
366 "The Future of Tammany_-Shall the Worst Elements Rule Our Cities?" The Progressive Farmer, March 10, 1891.

367 "Indifferent Voters: Duty of Christian Men in Politics," Boston Daily Globe, October 29, 1888.

${ }^{368}$ Ibid.

369 "Personals," Chicago Tribune, September 6, 1888.

370 "Indifferent Voters: Duty of Christian Men in Politics," Boston Daily Globe, October 29, 1888.
} 


\section{Chapter Three}

The Emergence of White Nationalism in Dixon's Public Works (1896-1901)

At the turn-of-the-century Dixon reformulated his thoughts about achieving his ideal patriotic identity. By 1901, Anglo-Saxon nationalism permeated Dixon's ideology. He argued that the nation's future depended on maintaining the racial purity of its white population, and on building a national identity rooted in this whiteness. As in the early part of his ministry, Dixon sought to solve the socio-economic problems preventing the creation of this nationalism, but the issue of sectionalism, racial tensions, and government power and corruption, became Dixon's main concerns. His proposed remedies to these issues underwent significant shifts when compared to his thoughts at the beginning of the decade. Dixon slowly abandoned his dedication to Christian socialist and populist minded solutions to fostering a national identity. Instead, he began advocating an AngloSaxonist, Darwinian approach to U.S. citizenship and society as the key to solving the nation's problems. His ideological changes responded to three major historical events at the turn-of-the-century: the presidential election of 1896, the Spanish-American War of 1898, and the subsequent debate over imperialism, education, and citizenship. This chapter explores three main changes in Dixon's ideology during this period, including his movement away from populism, the development of his radical white nationalism, as well as the emergence of his fervent insistence on racial segregation and limited suffrage rights.

Dixon's ideological shifts responded to and contributed to larger historical trends during the years spanning from 1895-1901. During these six years, the issues of race, 
citizenship, and the limits of government power dominated American culture and politics.

Rapid industrialization, urbanization, and mass migration continued changing the

American landscape, creating larger divisions in social classes, while labor and racial violence increased, alongside disfranchisement and legalized segregation. ${ }^{371}$ The lasting economic effects of the panic of 1893 and subsequent economic depression exacerbated sectional and class tensions, shifting the country's focus from the local to the national. ${ }^{372}$ The result was a political realignment in favor of the Republican Party. The Democratic Party and the populists lost supporters as the depression persisted. 1896 marked a watershed moment in American party politics, as many former supporters of populism and(or) the Democratic Party switched their allegiances. ${ }^{373}$ The election resulted in the

\footnotetext{
${ }^{371}$ Natalie Ring, The Problem South: Region, Empire, and the New Liberal State, 1770-1930 (Athens: University of Georgia Press, 2012), 179.

${ }^{372}$ For more on political parties and voting patterns in the late-nineteenth and early-twentieth century, see: R. Hal Williams, Realigning America: McKinley, Bryan, and the Remarkable Election of 1896 (Lawrence: University Press of Kansas, 2010); Daria Frezza, The Leader and the Crowd: Democracy in American Public Discourse, 1880-1941 (Athens: University of Georgia Press, 2007); Mark Wahlgren Summers, Party Games: Getting, Keeping, and Using Power in Gilded Age Politics (Chapel Hill: University of North Carolina Press, 2004); John Gerring, Party Ideologies in America, 1828-1996 (Cambridge: Cambridge University Press, 2001); Mark Lawrence Kornbluh, Why America Stopped Voting: The Decline of Participatory Democracy and the Emergence of Modern American Politics (New York: New York University Press, 1999); Elisabeth S. Clemens, The People's Lobby: Organizational Innovation and the Rise of Interest Group Politics in the United States, 1890-1925 (Chicago: University of Chicago Press, 1997); Michael McGerr, The Decline of Popular Politics in the American North, 1865-1928 (New York: Oxford University Press, 1986); and Years of Decision: American Politics in the 1890s (New York: Wiley, 1978)

${ }^{373}$ For more on this political realignment, see Williams, Realigning America (2010); University Press of Kansas, 2010); Carol A. Horton, Race and the Making of American Liberalism (New York: Oxford University Press, 2005); Patrick J. Kelly, "The Election of 1896 and the Restructuring of Civil War Memory," Civil War History 49, no. 3 (September 2003): 255; Stanley L. Jones, The Presidential Election of 1896 (Madison: University of Wisconsin Press, 1964); Paul W. Glad, McKinley, Bryan, and the People (Philadelphia: J.B. Lippencott, 1964); Robert F. Durden, The Climax of Populism: The Election of 1896 (Lexington: University of Kentucky Press, 1965); and Samuel T. McSeveney, The Politics of Depression: Political Behavior in the Northeast, 1893-1896 (New York: Oxford University Press, 1972); Robert W. Cherny, Populism and the Election of 1896 (New York: Grossman, 1974); Karl Rove, The Triumph of William McKinley: Why the Election of 1896 Still Matters (New York: Simon \& Schuster, 2015).
} 
death of the populist movement, a split in the Democratic Party, and installed the Republican Party as the dominant power in American politics.

The rhetoric used by the Republican Party platform in 1896 election reformulated populism into an "un-American" entity. The primary campaign issue in the '96 presidential campaign, between Democratic nominee William Jennings Bryan and Republican William McKinley, focused on currency standards. Populists, convinced that an increase in coinage would fix the country's economic situation, aligned with some Democrats in supporting Bryan. The Republican platform fervently opposed the free coinage of silver, arguing that such a policy would result in inflation and devalued currency, economic isolation, lower wages for the working and middle classes, as well as sectional problems. ${ }^{374}$ The rhetoric of the Republican campaign leading up to the 1896 election appealed to nationalist priorities. A crucial part of its platform emphasized a renewed nationalism based on sectional reconciliation. ${ }^{375}$ According to the GOP, class warfare threatened America's economic growth and progress, and would prevent national reconciliation by igniting not just class but sectional fault lines. Bryan's monetary policies, in this formulation, encouraged class tensions, endangering the nation. The Republican Party branded political protest against America's growing socio-economic inequalities as unpatriotic threats to unity. ${ }^{376}$

Simultaneously, the Spanish-American War of 1898 incited a nationwide conversation about the global obligations of the country, the importance of sectional

\footnotetext{
${ }^{374}$ Williams, Realigning America, 140.

${ }^{375}$ Kelly, "The Election of 1896 and the Restructuring of Civil War Memory," 255.

${ }^{376}$ Ibid, 258.
} 
reconciliation in constructing nationalism, the best methods for educating American citizens, and how issues of race would play out over the next several decades. ${ }^{377}$

Historians mark the Spanish-American War as the event that crystallized the prominence of a masculine Anglo-Saxonism throughout much of white American culture, as the people placed faith in the "destiny" of the Aryan/Teutonic race. ${ }^{378}$ Anglo-Saxon (also known as Nordicist or Teutonic) theories linked whiteness with inherent democratic traits, racializing popular government. William Z. Ripley's 1899 The Races of Europe divided the region's peoples into three groups, Teutonic, Alpine, and Mediterranean, based on physical features, with Teutons (also known as Aryan or Anglo-Saxon) at the top of the hierarchy. ${ }^{379}$ That same year, Houston Stewart Chamberlain's Foundations of the Nineteenth Century placed race at the center of all history, and the Aryan race as the proven success story. ${ }^{380}$ This supported Edward A. Freeman's belief in the possibilities

\footnotetext{
${ }^{377}$ Several recent academic analyses focus on the importance of the Spanish-American War in spurring conversations about race, nationalism, and citizenship, as well as the war's contributions to twentieth century American identity. See: Paul T. McCartney, Power and Progress: American National Identity, the War of 1898, and the Rise of American Imperialism (Baton Rouge: Louisiana State University Press, 2006); Walter L. Hixson, The Myth of American Diplomacy: National Identity and U.S. Foreign Policy (New Haven: Yale University Press, 2008); Virginia Marie Bouvier, ed., Whose America? The War of 1898 and the Battles to Define the Nation (Westport: Praeger, 2001); and Carroll Smith-Rosenberg, This Violent Empire: The Birth of an American National Identity (Chapel Hill, University of North Carolina Press, 2010).

${ }^{378}$ Historian Gail Bederman best demonstrates this point in her 1995 work, Manliness \& Civilization: A Cultural History of Gender and Race in the United States, 1880-1917 (Chicago: University of Chicago Press, 1995). For more on the changing terms of masculinity and/or their relationship to race in this period, see also: Kevin P. Murphy, Political Manhood: Red Bloods, Mollycoddles, and the Politics of Progressive Era Reform (New York: Columbia University Press, 2008); John Pettegrew, Brutes in Suits: Male Sensibility in America, 1890-1920 (Baltimore: Johns Hopkins University Press, 2007); Martin Anthony Summers, Manliness and its Discontents: The Black Middle Class and the Transformation of Masculinity, 1900-1930 (Chapel Hill: University of North Carolina Press, 2004); and Mark C. Carnes and Clyde Griffen, eds., Meanings for Manhood: Construction of Masculinity in Victorian America (Chicago: University of Chicago Press, 1990).

${ }^{379}$ Painter, The History of White People, 212-227.

${ }^{380}$ Jackson and Weidman, “The Origins of Scientific Racism,” 70-71.
} 
of a transatlantic Teutonic alliance with the aim of ruling the world. In combination with works such as these, Vacher de Lapouge's anthroposociology, developed best in Social Selection (1896) and The Aryan and His Social Role (1899) linked hard racial heredity with social characteristics, advocating the elimination of inferior races as the only solution to racial problems. ${ }^{381}$ In this line of thinking, America, as an Anglo-Saxon nation with the racial heritage of democracy, derived its power from its racial makeup. The world's civilizations and creativity originated with the Anglo-Saxon, or the "Aryan" race. A powerful Anglo-Saxon alliance could rule the world and, in these works, it was their responsibility to protect the "lesser" races. ${ }^{382}$

Anglo-Saxonism increased in popularity and, for its supporters, justified the disfranchisement and segregation sweeping the county. After Plessy vs. Ferguson legally sanctioned segregation in 1896, racial separation measures spread rapidly throughout the country. In the North and West, as in the South, African Americans were marginalized at the polls, barred from economic opportunities in the labor market, suffered mob violence, and experienced multiple forms of segregation. "S83 "Separate but equal" facilities spread through the nation, facing challenges from nonwhite Americans. Fears of a "race war" became common among Americans of all races, as racial tensions persisted. ${ }^{384}$ By 1900 , "lynching mania" had spread not only in the South, but "throughout the North and middle

\footnotetext{
381 Jackson and Weidman, "The Origins of Scientific Racism," 70-71.

382 Ibid.

${ }^{383}$ Desmond King and Stephen G.N. Tuck, "Decentering the South: America's Nationwide White Supremacist Order After Reconstruction," Past \& Present 194 (February 2007): 219.

${ }^{384}$ Ring, The Problem South, 179.
} 
West" as well. ${ }^{385}$ During the 1890 s, in the South, political and legal efforts combined with extralegal intimidation disfranchised many African Americans and poor whites. North Carolina followed the lead of Mississippi, South Carolina, and Louisiana by introducing a constitutional amendment to systematically disfranchise African Americans and many poor whites using poll taxes, literacy tests, and residency requirements. ${ }^{386}$ By 1903, every Southern state had enacted suffrage requirements curtailing "undesirable" voters of both races. In Louisiana, for instance, the new voting law reduced registration significantly. The year before the law went into effect, 95.6 percent of blacks and 103.2 percent of whites were registered to vote; the next year those numbers were 9.5 percent for African Americans and 46.6 percent of whites. ${ }^{387}$ Similar laws appeared throughout the North. ${ }^{388}$

The aftermath of the Spanish-American War forced Americans to reassess its flaws as a newly imperial nation, bringing the South, race, and labor into the spotlight. The nation's new territorial responsibilities in Puerto Rico and the Philippines shaped American debates about race, citizenship, and the nation. The Spanish-American War made many white Americans hyper-aware of their Anglo-Saxon heritage and highly interested in maintaining the nation's whiteness. These biologically determined forms of whiteness assisted in popularizing white supremacy, but complicated the discussion of Americanism and citizenship. Nonwhite peoples assumed predisposition to poor

\footnotetext{
${ }^{385}$ King and Tuck, "Decentering the South," 226.

${ }^{386}$ Richardson, The Death of Reconstruction, 224.

${ }^{387}$ Ibid.

${ }^{388}$ Ibid.
} 
behavior presented a challenge to the notion that they might be incorporated into the voting population. This conundrum represents, in microcosm, the early-twentieth century conflict between biological and environmental determinism. The Social Darwinism of the late-nineteenth century clashed with the work of Franz Boas, which emphasized the importance of culture. These competing scientific perspectives triggered differing opinions about the ability of African Americans, immigrants, and poor whites to receive an education in "proper" citizenship.

Scientific discussions of race also drove debates about imperialism, with supporters and detractors adopting different theories of determinism. ${ }^{389}$ If, as Anglo Saxonist logic insisted, the country's power and democratic foundation was derived from its racial purity, then maintaining America's whiteness was crucial not only for the nation, but for the entire world. Imperial responsibility, however, demanded that America "civilize" the "lesser races" of brown people in the Philippines and Puerto Rico by teaching them the basic tenets of democracy. This created a quandary in terms of race relations: if democratic tendencies were the genetic gifts of Anglo-Saxons, could a nonwhite race be taught democracy? If so, did that mean African Americans and immigrants were capable of the same sort of education? And, if so educated, could these people be assimilated into the nation? If so, in what social structures would these "lesser" races be considered equal? These questions contributed to the prominent early-1900s debates over whether or not certain groups of American subjects were citizens, and which groups were automatically guaranteed voting rights.

\footnotetext{
${ }^{389}$ For an in-depth analysis of this debate, see Fabian Hilfrich, Debating American Exceptionalism: Empire and Democracy in the Wake of the Spanish-American War (New York: Palgrave Macmillan, 2012).
} 
At the turn-of-the-century, these issues again rose to national prominence when

the liberal reformism of the 1890 s became a viable political force in the form of

Progressivism. ${ }^{390}$ The continuing ills plaguing the nation convinced these reformers of

the need for a democratic overhaul, both politically and culturally. Progressives

continued to champion improvement through legislative change, but emphasized a social

science approach to constructing these solutions. They believed the new nation could

\footnotetext{
${ }^{390}$ There is much historiographical debate over the periodization of the progressivism, as an ideology and social trend toward reformism, and its relationship to the Progressive movement, a political force in the early-twentieth century. In this work, I use the lower-case "progressivism" to refer to the former, which emerged visibly in the 1880 s and 1890 s, and view it as a precursor to the later, politically successful Progressive movement of the later decades. For more on the history of progressivism and the Progressive movement, see: Thomas C. Leonard, Illiberal Reformers: Race, Eugenics, and American Economics in the Progressive Era (Princeton: Princeton University Press, 2016); Michael Wolraich, Unreasonable Men: Theodore Roosevelt and the Republican Rebels Who Created Progressive Politics (New York: Palgrave Macmillan, 2014); William G. Ross, A Muted Fury: Populists, Progressives, and Labor Unions Confront the Courts, 1890-1937 (Princeton: Princeton University Press, 2014); Robert D. Johnston, "The Possibilities of Politics: Democracy in America, 1877 to 1917," in American History Now, edited by Eric Foner and Lisa McGirr (Philadelphia: Temple University Press, 2011); John D. Fairfield, The Public and Its Possibilities: Triumphs and Tragedies in the American City (Philadelphia: Temple University Press, 2010); Jackson Lears, Rebirth of a Nation: The Making of Modern America, 1877-1920 (New York: Harper Collins, 2009); Kevin P. Murphy, Political Manhood: Red Bloods, Mollycoddles, and the Politics of Progressive Era Reform (New York: Columbia University Press, 2008); Doug Rossinow, Visions of Progress: The Left-Liberal Tradition in America (University Park: University of Pennsylvania Press, 2008); Maureen A. Flanagan, America Reformed: Progressivism and Progressivisms, 1890s-1920s (New York: Oxford University Press, 2007); Rebecca Edwards, New Spirits: Americans in the Gilded Age, 18651905 (New York: Oxford University Press, 2006); Steven L. Piott, American Reformers, 1870-1920: Progressives in Word and Deed (Lanham, Maryland: Rowman \& Littlefield, 2006); Shelton Stromquist, Reinventing "The People": The Progressive Movement, the Class Problem, and the Origins of Modern Liberalism (Urbana: University of Illinois Press, 2006); Marc Stears, Progressives, Pluralists, and the Problems of the State: Ideologies of Reform in the United States and Britain, 1909-1926 (Oxford: Oxford University Press, 2006); Michael McGerr, A Fierce Discontent: The Rise and Fall of the Progressive Movement in America (New York: Oxford University Press, 2003); Daniel Rodgers, Atlantic Crossings: Social Politics in a Progressive Age (Cambridge: Harvard University Press, 1998); Steven J. Diner, A Very Different Age: Americans of the Progressive Era (New York: Hill and Wang, 1998); Leon Fink, Progressive Intellectuals and the Dilemmas of Democratic Commitment (Cambridge: Harvard University Press, 1997); Eldon J. Eisenach, The Lost Promise of Progressivism (Lawrence: University Press of Kansas, 1994); Sean Dennis Cashman, America in the Gilded Age: From the Death of Lincoln to the Rise of Theodore Roosevelt (New York: New York University Press, 1993); Alan Dawley, Changing the World: American Progressives in War and Revolution (Princeton: Princeton University Press, 2003) and Struggles for Justice: Social Responsibility and the Liberal State (Cambridge: Belknap Press, 1991); Martin Sklar The United States as a Developing Country: Studies in U.S. History in the Progressive Era and the 1920s (New York: Cambridge University Press, 1992); Peter J. Frederick, Knights of the Golden Rule: The Intellectual as Social Reformer in the 1890s (Lexington: University Press of Kentucky, 1976); and Richard Hofstadter, The Age of Reform: From Bryan to F.D.R. (New York: Knopf, 1955).
} 
only succeed through a combination of federal and individual action: the creations of a "new democracy" to match the new, modern America, and a new educational system to train ideal citizens. In the process, these reformers defined what it meant to be "American," and what groups were included in that description. In addition, the country's new responsibilities as an imperial power created a perceived pressure to attain the highest standards of civilization and serve as a global model of democracy while African Americans, colonial peoples, and women challenged the status quo of predominantly white male citizenship. Reformers, however, differed in opinion on how to deal with these nonwhite peoples in a democracy founded on the basis of equality. They also disagreed over exactly who was, indeed, "white."

Across the nation, African Americans, white reformers, and white conservatives proposed a myriad of competing theories. In these discussions, the South, race, and nationalism intersected. Among Progressive whites, two general schools of thought emerged regarding immigrants' place in the new nation. Left-leaning reformers, like John Dewey, Jane Addams, and Randolph Bourne, envisioned the future American as the first "international nation," where immigrants could incorporate the cultures of their homeland into a broader American cosmopolitanism. ${ }^{391}$ Right-leaning reformers, meanwhile, like Theodore Roosevelt and Herbert Croly, called for a "New Nationalism" that assimilated white immigrants to meet a set of behavioral American standards. ${ }^{392}$ This would create a "new race, a new type, in this country," something entirely American

\footnotetext{
${ }^{391}$ Noah Pickus, True Faith and Allegiance: Immigration and American Civil Nationalism (Princeton: Princeton University Press, 2009), 64-65.

${ }^{392}$ Ibid.
} 
and unique. ${ }^{393}$ Both approaches relied on education as the key to national progress and immigrants' assimilation, and both envisioned a predominantly white nation in the future. Similar divisions existed when the subject turned to African Americans as citizens. Most white Progressives viewed African Americans as a "lesser" race, incapable of responsibly exercising the ballot. The predominant vision of the ideal America involved a white, Anglo-Saxon majority, at least in the short term. The major difference in terms of the ideal place for African Americans came in the form of future plans: some reformers championed colonization, others segregation, a portion favoring equal opportunity, and others industrial education. ${ }^{394}$

Gender and sexuality intertwined with the nation's negotiations of race, nationalism, and equality. ${ }^{395}$ At the turn-of-the-century, white Americans began fearing

\footnotetext{
${ }^{393}$ Pickus, True Faith and Allegiance, 85.

${ }^{394}$ Andrew Rieser, The Chautauqua Moment: Protestants, Progressives, and the Culture of Modern Liberalism (New York: Columbia University Press, 2003), 150.
}

\footnotetext{
${ }^{395}$ Several historians have examined the influence and importance of gender and sexuality in latenineteenth and early-twentieth century debates about citizenship. See: Gail Bederman's Manliness and Civilization: A Cultural History of Gender and Race in the United States, 1880-1917 (Chicago: University of Chicago Press, 1995); Glenda Elizabeth Gilmore, Gender and Jim Crow: Women and the Politics of White Supremacy in North Carolina, 1896-1920 (Chapel Hill: University of North Carolina Press, 1996); Sandra Gunning, Race, Rape, and Lynching: The Red Record of American Literature, 1890-1912 (New York: Oxford University Press, 1996); Kristin L. Hoganson, Fighting for American Manhood: How Gender Politics Provoked the Spanish-American and Philippine-American Wars (New Haven: Yale University Press, 1998); Rebecca Edwards, Angels in the Machinery: Gender and American Party Politics from the Civil War to the Progressive Era (New York: Oxford University Press, 1997); Mason Stokes, The Color of Sex: Whiteness, Heterosexuality, and the Fictions of White Supremacy (Durham: Duke University Press, 2001); Evelyn Nakano Glenn, Unequal Freedom: How Race and Gender Shaped American Citizenship and Labor (Cambridge: Harvard University Press, 2002); Elise Lemire, “Miscegenation": Making Race in America (Philadelphia: University of Pennsylvania Press, 2002); Martha Gardner, The Qualities of a Citizen: Women, Immigration, and Citizenship, 1870-1965 (Princeton: Princeton University Press, 2005); Martha Gardner, The Qualities of a Citizen: Women, Immigration, and Citizenship, 1870-1965 (Princeton: Princeton University Press, 2005); Julian B. Carter, The Heart of Whiteness: Normal Sexuality and Race in America, 1880-1940, (Durham: Duke University Press, 2007); Peggy Pascoe, What Comes Naturally: Miscegenation Law and the Making of Race in America (New York: Oxford University Press, 2009); Priscilla Yamin, "The Search for Marital Order: Civic Membership and the Politics of Marriage in the Progressive Era," Polity 41, no. 1 (January 2009): 86-112; Kimberly A. Hamlin, From Eve to Evolution: Darwin, Science, and Women's Rights in Gilded Age America (Chicago: University of Chicago Press,
} 
"race suicide," that nonwhites would grow to outnumber and politically out power Anglo-Saxons. This threat seemed so real in this historical moment that President Teddy Roosevelt informed young white Americans it was their duty as citizens to perpetuate the race. ${ }^{396}$ The same fear of racial endangerment drove later eugenic efforts to stem the numbers of "unfit" children being born. White womanhood and masculinity played large roles in defining the nation and shaping its color lines. Since Anglo-Saxonism located national power in its purity, white women held an important position as bearers of future Americans. African Americans were perceived as posing a threat to white bloodlines, and black men and women were often portrayed as sexually licentious and dangerous. American masculinity in this period demanded protection of white womanhood, and thus, national purity, from threats. These included uncontained black lust as well as changes in marriage and gender relations. Miscegenation laws appeared in Southern states, but also in Maine, Rhode Island, Michigan, Illinois, Ohio, California, Nebraska, and Washington. ${ }^{397}$ These laws limited white-nonwhite marriage, including unions between whites and African Americans, Asian Americans, and Native Americans, further delineating the terms of whiteness.

The debate over racial equality and citizens' rights allowed for other groups to challenge the status quo. Black activism played a significant role in drawing attention to

\footnotetext{
2014); Melissa N. Stein, Measuring Manhood: Race and the Science of Masculinity, 1830-1934 (Minneapolis: University of Minnesota Press, 2015); and Sarah Haley, No Mercy Here: Gender, Punishment, and the Making of Jim Crow Modernity (Chapel Hill: University of North Carolina Press, 2016).

${ }^{396}$ Edwards, Angels in the Machinery, 154.

${ }^{397}$ Pascoe, What Comes Naturally, 6.
} 
problems of race throughout the nation. ${ }^{398}$ In 1890, the National Convention of Colored

Americans protested to the federal government, asking for stronger laws preventing travel segregation, followed later by the National Afro-American League. ${ }^{399}$ At the turn-of-thecentury, the Afro-American Council emerged to battle racism, discrimination, and mob violence using the courts and legislatures. ${ }^{400}$ Part of the Council's strategy involving lecturer-author-activist Ida B. Wells and the Anti-Lynching Bureau. Wells toured the East Coast and published articles exposing the horrors of lynching throughout the nation,

\footnotetext{
${ }^{398}$ See the following works for more information on African American civil rights activism and its leaders in the late-nineteenth and early-twentieth centuries: August Meier and John H. Bracey, Jr., "The NAACP as a Reform Movement, 1909-1965: 'To Reach the Conscience of America',' The Journal of Southern History 59, no. 1 (February 1993): 3-30; Kevin Kelly Gaines, Uplifting the Race: Black Leadership, Politics, and Culture in the Twentieth Century (Chapel Hill: University of North Carolina Press, 1996); Tunde Adeleke, UnAfrican Americans: Nineteenth Century Black Nationalists and the Civilizing Mission (Lexington: University Press of Kentucky, 1998); Rod Bush, We Are Not What We Seem: Black Nationalism and Class Struggle in the American Century (New York: New York University Press, 1999); Cedric J. Robinson, Black Marxism: The Making of the Black Radical Tradition (Chapel Hill: University of North Carolina Press, 2000); William F. Pinar, "The N.A.A.C.P. and the Struggle for Antilynching Legislation, 1897-1917," Counterpoints 163 (2001): 623-682; Steven Hahn, A Nation Under Our Feet: Black Political Struggles in the Rural South from Slavery to the Great Migration (Cambridge: Harvard University Press, 2003); Richard M. Valelly, The Two Reconstructions: The Struggle for Black Enfranchisement (Chicago: University of Chicago Press, 2004); Gilbert Jonas, Freedom's Sword: The NAACP and the Struggle Against Racism in America, 1909-1969 (New York: Routledge, 2005); Michael Rudolph West, The Education of Booker T. Washington: American Democracy and the Idea of Race Relations (New York: Columbia University Press, 2006); Peter C. Myers, Frederick Douglass: Race and the Rebirth of American Liberalism (Lawrence: University Press of Kansas, 2008; R. Volney Riser, Defying Disfranchisement: Black Voting Rights Activism in the Jim Crow South, 1890-1908 (Baton Rouge: Louisiana State University Press, 2010); Mitch Kachun: “'Big Jim' Parker and the Assassination of William McKinley: Patriotism, Nativism, Anarchism, and the Struggle for African American Citizenship," Journal of the Gilded Age and Progressive Era 9, no. 1 (January 2010): 93-116; Gene Andrew Jarrett, Representing the Race: A New Political History of African American Literature (New York: New York University Press, 2011); Faye E. Dudden, Fighting Chance, The Struggle over Woman Suffrage and Black Suffrage in Reconstruction America (New York: Oxford University Press, 2011); Shawn Leigh Alexander, An Army of Lions: The Civil Rights Struggle Before the NAACP (Philadelphia: University of Pennsylvania Press, 2012); Jay Winston Driskell, Jr., Schooling Jim Crow: The Fight for Atlanta's Booker T. Washington High School and the Roots of Black Protest Politics (Richmond: University of Virginia Press, 2014); and E.M. Beck, "Judge Lynch Denied: Combating Mob Violence in the American South, 1877-1950," Southern Cultures 21, no. 2 (Summer 2015): 117-139.

${ }^{399}$ Upchurch, Legislating Racism, 205.

${ }^{400}$ Alexander, An Army of Lions, 136-139.
} 
raising both awareness and funds for the Council's projects. ${ }^{401}$ Their work laid the way for the Niagara Movement, which began in 1905, and the later National Association for the Advancement of Colored People (NAACP). In the form of interracial political alliances, African Americans posed a significant threat to political white dominance, achieving interracial majority in multiple state legislatures in the late-nineteenth century. African American activism also became more visible through the publications of new periodicals such as Colored American Magazine, Voice of the Negro, and Alexander's Magazine. Prominent black leaders like W.E.B. DuBois, Booker T. Washington, Kelly Miller, and Archibald Grimke published works addressing the problem of race.

The debate over modern citizenship and suffrage also drew attention to the American South, connecting the region inextricably with problems of race. Many discussions of the race problem viewed it as a strictly Southern problem that prevented the region from modernizing and the nation from unifying. ${ }^{402}$ Soon, remedying the race problem in the South became a central element of Progressive reform. In debating a solution, reformers questioned the nature of Southern progress, its socio-economic status, and the consequences of its current state of affairs for the rest of the country: Did the South meet the standards of the new nation? What role did the region play in perpetuating national problems? How should the government deal with resistance to civilizing efforts in backwards regions like the colonies and the South? Did this contradict Constitutional states' rights? Were poor, white Southerners even considered "American?" As they analyzed the South, Progressives concluded "the Caucasian

\footnotetext{
${ }^{401}$ Alexander, An Army of Lions, 136-139.

${ }^{402}$ Ring, The Problem South, 178-179.
} 
problem" to be "the new race question." "403 Solving problems of national reconciliation and race needed to begin with "uplifting" and "readjusting" poor white Southerners. ${ }^{404}$ Reformers embarked on missions to change social standards and health practices via education. $^{405}$

The "Conference for Christian Education in the South," a series of meetings amongst Southern educators and Northern ministers held in West Virginia from 1898 to 1900, concentrated on resolving the region's educational flaws. ${ }^{406}$ In 1901, this movement coalesced into the Southern Education Board (SEB). Comprised of Progressives from both the North and the South, the SEB promoted public education as

\footnotetext{
${ }^{403}$ Ring, The Problem South, 135-138.
}

${ }^{404}$ Ibid.

${ }^{405}$ Further information on educational reform efforts in this period, and their relationship to race and citizenship, see: Louis R. Harlan, "The Southern Education Board and the Race Issue in Public Education," The Journal of Southern History 23, no. 2 (May 1957): 189-202; Harvey Wish, "Negro Education and the Progressive Movement," The Journal of Negro History 49, no. 3 (July 1964): 184-200; Spencer J. Maxcy, "The Idea of Consolidation in Southern Education During the Early Decades of the Twentieth Century," Peabody Journal of Education 53, no. 3 (April 1976): 216-222; William A. Link, "Making the Inarticulate Speak: A Reassessment of Public Education in the Rural South, 1870-1920," Journal of Thought 18, no. 3 (Fall 1983): 63-75; Mustafa Emirbayer, "Beyond Structuralism and Voluntarism: The Politics and Discourse of Progressive School Reform, 1890-1930," Theory and Society 21, no. 5 (October 1992): 621664; David B. Tyack and Larry Cuban, Tinkering Toward Utopia: A Century of Public School Reform (Cambridge: Harvard University Press, 1995); Julie A. Reuben, "Beyond Politics: Community Civics and the Redefinition of Citizenship in the Progressive Era," History of Education Quarterly 37, no. 4 (Winter 1997): 399-420; Joseph Moreau, Schoolbook Nation: Conflicts Over American History Textbooks from the Civil War to the Present (Ann Arbor: University of Michigan Press, 2004); Joan Malczewski, "Weak State, Stronger Schools: Northern Philanthropy and Organizational Change in the Jim Crow South," The Journal of Southern History 75, no. 4 (November 2009): 963-1000; Kristina DuRocher, Raising Racists: The Socialization of White Children in the Jim Crow South (Lexington: University Press of Kentucky, 2011); Thomas Fallace, "Recapitulation Theory and the New Education: Race, Culture, Imperialism, and Pedagogy, 1894-1916," Curriculum Inquiry 42, no. 4 (2012): 510-533; Tracy Lynn Steffes, School, Society, and State: A New Education to Govern Modern America, 1890-1940 (Chicago: University of Chicago Press, 2012); and Amy J. Wan, Producing Good Citizens: Literacy Training in Anxious Times (Pittsburgh: University of Pittsburgh Press, 2014).

${ }^{406}$ Clinton B. Allison, "The Conference for Education in the South: An Exercise in Noblesse Oblige," Journal of Thought 16, no. 2 (Summer 1981): 39-40. 
the key to national reconciliation and regional renewal. ${ }^{407}$ Robert C. Ogden, manager of a New York department store and trustee at both the Hampton and Tuskegee Institutes, led the group. Other Northerners included George Foster Peabody, a Wall Street banker, and railroad president William H. Baldwin, Jr. ${ }^{408}$ Charles D. McIver, Edwin A.

Alderman, and Charles Dabney, all college Presidents in the South, offered the regional counterbalance. Southerners living in the North, Walter Hines Page and Jabez L.M. Curry, provided an intersectional view. ${ }^{409}$ "Moved by ethical and patriotic incentives," members of the SEB possessed "the common belief that the general education of all the people is essential to the salvation of society." Without it, "progress... family peace, clean living, human brotherhood, civic righteousness and national justice is impossible." ${ }^{410}$ The SEB's task was raising funds to establish public schools throughout the South, which would be supplemented by federal, state, and philanthropic efforts. Ogden packed railcars full of Northern philanthropists, toured them throughout the South, and then sold them his program of education. The SEB's program became intimately associated with its President, known widely as "Ogdenism" or "the Ogden movement." "411

The first step to solving the South's race problems, according to the SEB, was a democratic education. Most members of the SEB accepted the doctrine of black

\footnotetext{
${ }^{407}$ Allison, "The Conference for Education in the South," 39-40.

${ }^{408}$ Louis R. Harlan, "The Southern Education Board and the Race Issue in Public Education," The Journal of Southern History 23, no. 2 (May 1957): 190.

${ }^{409}$ Ibid.

${ }^{410}$ Robert C. Ogden, "The Conference for Education in the South," Annals of the American Academy of Political and Social Science (September 1903): 29-30.

${ }^{411}$ Eric Anderson and Alfred A. Moss, Jr., Dangerous Donations: Northern Philanthropy and Southern Black Education, 1902-1930 (Columbia: University of Missouri Press, 1999), 5-15.
} 
inferiority, viewing upper-class white-guided education as a necessary step in African Americans' racial progress. ${ }^{412}$ Simultaneously, the Board identified blacks as "natives and not intruders," rejecting the idea of coerced colonization as a "crime" and "physical impossibility. ${ }^{, 413}$ They believed education of both races was a required element in forming racial peace and national reconciliation. "Bestowing benefits on the white boy of the South, and at the same time lending a helping hand to the weaker race," Lyman Hall maintained, "will surely prepare means for... the preservation of the prestige of their inheritance, for the great destiny which beckons them to prepare for future conflicts... with the greatest nations of the earth." ${ }^{, 414}$ An ideal education would teach all Southerners "habits of thrift, love of home and the land, manual skill, obedience to the law, respect for one's neighbor, in a word, clean and effective living." ${ }^{415}$ In practice, though, many of their financial and physical efforts aimed at poor white Southerners. The racial hierarchy of early Jim Crow prevented some of the SEB's plans.

White supremacy's increasing strength in the South drove the SEB's focus on educating the region's people. The group adopted a relatively moderate stance on racial reform. ${ }^{416}$ Only slow, cautious, and patient methods of instilling equality would be useful

\footnotetext{
${ }^{412}$ Allison, "The Conference for Education in the South," 44.

${ }^{413}$ Charles B. Galloway, "Bishop Galloway," in Proceedings of the Conference for Education in the South: The Seventh Session (The Committee on Publication: New York, 1906), 29-30.

${ }^{414}$ Lyman Hall, "Needs of the New South," Annals of the American Academy of Political Science 22 (September 1903): 26.

415 "Resolutions," in Proceedings of the Fourteenth Conference for Education in the South: Jacksonville, Florida (Executive Committee of the Conference, 1911).

${ }^{416}$ The actual intent of the Southern Education Board regarding racial equality is a matter of historiographical debate. Some historians argue the reformers submitted reluctantly to the constraints of white supremacy while others portray the group as committed to similar hierarchical ideas of race. See the earliest framework of this debate in: Louis R. Harlan, Separate and Unequal: Public School Campaigns
} 
in the U.S. South. ${ }^{417}$ Members of the SEB identified entrenched intolerance among younger generations of poor whites, exacerbated by their illiteracy, as a large source of problems between the races. ${ }^{418}$ This hatred, according to the SEB, stemmed from the legacy of Reconstruction, which "poisoned the spirit of one race and aroused the fierce antagonism of the other." ${ }^{419}$ White reformers decided that Southerners could be taught racial tolerance as a larger part of their democratic education. This would improve race tolerance, allowing white and black Southerners to live together in harmony. Due to the explosive nature of an attempt at establishing equality in the South, however, this racial tolerance needed to align with segregation. ${ }^{420}$ Attempting to establish social equality risked undermining the SEB's entire agenda. Success depended on white Southerners' acceptance of the Board's plans. Most Southern whites expected their race to be "the leaders... to have the directive control in all matters pertaining to civilization and the highest interest of our beloved land," since "history demonstrates that the Caucasian will rule." ${ }^{, 421}$ The SEB concluded that segregation could not be circumvented, as a "middle wall of partition which will not be broken down" caused separation to be "desired alike

and Racism in the Southern Seaboard States, 1901-1915 (Chapel Hill: University of North Carolina Press, 1958); James D. Anderson, The Education of Blacks in the South (Chapel Hill: University of North Carolina Press, 1988); and Henry Allen Bullock, A History of Negro Education in the South: From 1619 to the Present (Cambridge: Harvard University Press, 1967); For a more recent interpretation, see Anderson and Moss, Dangerous Donations (1999).

${ }^{417}$ Anderson and Moss, Dangerous Donations, 40.

${ }^{418}$ Ring, The Problem South, 191.

${ }^{419}$ Josephus Daniels, "The Progress of Southern Education," in Proceedings of the Conference for Education in the South: The Sixth Session (The Committee on Publication: New York City, 1903), 144. ${ }^{420}$ Allison, 46; Harlan, 191-192.

${ }^{421}$ J.L.M. Curry, "Education in the Southern States," in Proceedings of the Second Capon Springs Conference for Education in the South, 1899 (Raleigh: Edwards \& Broughton, Printers and Binders, 1899), 38 . 
by both races." ${ }^{422}$ Political power of the South would also remain at the status quo, with whites in power. A "friendship" between white and black Southerners, the SEB hoped, would form out of its educational efforts, leading to better protections and opportunities for African Americans. With racial tensions banished, the region would be able to progress and the nation able to reconcile. ${ }^{423}$

Despite efforts to sell compulsory education as a necessity compatible with the popular doctrine of white supremacy, the majority of Southerners reacted unfavorably. Most white Southerners opposed public funding of African Americans' education, resulting in uneven distributions of funds that reinforced racial inequality. ${ }^{424}$ Whites' public criticisms of the SEB's plans revolved around three basic assertions. The first charged Northern reformers with possessing a secret agenda to institute racial citizenship equality, undermining the South's system of white supremacy and potentially encouraging miscegenation. ${ }^{425}$ Critics also charged that many members of the SEB held condescending attitudes about Southerners, believing it to be inferior to the rest of the nation. ${ }^{426}$ A fear that the SEB would create an educational monopoly run by Northern interests intermingled with worries over race and sectional stereotypes. ${ }^{427}$ Worse, it might rekindle a movement for federal involvement, possibly stripping the states of their

\footnotetext{
${ }^{422}$ Charles B. Galloway, "Bishop Galloway," in Proceedings of the Conference for Education in the South: The Seventh Session (The Committee on Publication: New York, 1906), 29-30.

${ }^{423}$ Ibid.

${ }^{424}$ Anderson and Moss, Dangerous Donations, 39.

${ }^{425}$ Ibid, 49-53.

${ }^{426}$ Ibid.

${ }^{427}$ Ibid.
} 
control over education in yet another way. Some Southerners believed educational reform was an effort to keep African Americans from migrating North. ${ }^{428}$ The backlash was widespread; historian James W. Patton compared it to white protests against the antisegregation Supreme Court decisions of the 1950s. ${ }^{429}$

During this same tumultuous period from 1895 to 1901, Dixon underwent a series of three vital changes to his ideology. These changes were not immediately evident, at first. After Dixon left the Twenty-Third Street Baptist Church in 1895, he opened his own "People's Church" where, at first, many of his messages remained identical to those of his earlier sermons. Dixon continued his efforts at reforming American life by influencing his constituency to apply Christian morality to socio-economic and political issues. "I am not here to echo public sentiment," Dixon informed his congregation, "but to create it." ${ }^{, 40}$ The design of his People's Church intended to reach non-church-going people, a matter he believed was of crucial importance in reforming the nation. ${ }^{431}$ Members of the new church united under the motto "in essentials, unity; in nonessentials, liberty; in all things, charity." ${ }^{, 432}$ From his new pulpit at the Academy of

\footnotetext{
${ }^{428}$ Anderson and Moss, Dangerous Donations, 49.

${ }^{429}$ James W. Patton, "The Southern Reaction to the Ogden Movement," in Education in the South: Institute of Southern Culture Lectures at Longwood College, 1959, edited by R.C. Simonini, Jr., (Farmville: Longwood College 1959), 71.

430 "Pulpit Voices: Religious Thought and Progress in the United States," Los Angeles Times, October 31, 1897.

431 "Rev. Thomas Dixon Resigns: He Will Engage in Special Work to Reach Non-Church-Going People," The Sun (Baltimore), March 11, 1895; "Pastor Resigned," Los Angeles Times, March 11, 1895.

432 "Dixon's Church the People's: He Will Preach in the Academy of Music Sunday Mornings," New York Times, March 18, 1895.
} 
Music, Dixon intended to speak on specific issues of "supreme importance."433 $\mathrm{He}$ named four specific topics, including the "non-essentiality" of "ceremonies, rituals, places, paper creeds and Church officialism," emphasizing instead the "freedom of the individual conscience and the individual Church." $" 344$ He also sought to "restate in the language of modern life... the Gospel of Jesus Christ" and to present "old faiths in new lights... to rebuild the crumbling faith of thousands who have left the church." ${ }^{, 435}$ Proclaiming the "sacredness of the secular" emerged as the third element in his new religious mission. ${ }^{436}$ In addition, Dixon argued, "political economy must be humanized until men know that production is communion with God, and distribution a human fellowship. $" 437$

The first of these seminal changes emerged in Dixon's rhetoric from late-1895 to 1897, where his support of populism and advocacy of a swift, working-class revolution dissipated in favor of a moderate approach to reform. He now desired a slower approach to change that emphasized better the nation, as a whole, rather than a single section. Rather than viewing a collective, populist-socialist inspired revolution as one step toward solving the country's five major problems, as in previous sermons, by 1896 Dixon argued that meeting populists' demands would exacerbate socio-economic and sectional

\footnotetext{
433 "Rev. Thos. Dixon Resigns: He Quits the Twenty-Third Street Baptist Church May 1 to Organize an Independent One," New York Times, March 11, 1895; "Dixon's Church the People's: He Will Preach in the Academy of Music Sunday Mornings," New York Times, March 18, 1895.

${ }^{434}$ Ibid.

${ }^{435}$ Ibid.

${ }^{436}$ Ibid.

${ }^{437}$ Ibid.
} 
problems. Dixon's initial shift is most visible in the months surrounding the presidential election of 1896, which prompted the minister to dedicate larger portions of his weekly Sunday sermons to its main debates. ${ }^{438}$ During the 1896 campaign, Dixon publicly moved away from his early-1890s support of the populist movement and the Democratic Party and backed the Republican presidential candidate, William McKinley. He campaigned for McKinley, and denounced the possibilities for the social revolution that he wholeheartedly believed in earlier. ${ }^{439}$

Dixon's support of McKinley and the Republican Party marked the beginning of a new strain of conservatism in the minister's ideals, and was deeply rooted to his desire to end sectional animosities and construct a singular nationalism. Dixon concurred with the Republicans' assertion that Bryan's policy plans would exacerbate sectional tensions by pitting the farmers of the West and South against the industrial capitalists, further shattering the possible unity of the nation's people. To Dixon, the populist movement and the Democratic administration of President Grover Cleveland had failed to solve the nation's problems, and that the Bryan platform threatened to divide the nation as severely as the previous Civil War. Dixon, like other disillusioned Democrats, viewed the recent political alliance as a sign of poor judgment and that partisan politics and corruption still controlled Washington. This development convinced Dixon that the powerful labor

\footnotetext{
438 "Dixon Takes a Stand: Preacher Says He Will Talk Politics Every Sunday," Chicago Daily Tribune, September 9, 1896; For more on the election of 1896, see Realigning America: McKinley, Bryan, and Remarkable Election of 1896 (Lawrence: University Press of Kansas, 2010).

439 "North Carolina: Rev. Thomas Dixon and Speaker Reed to Speak for McKinley," The Sun (Baltimore), September 24, 1896; "Rev. Thomas Dixon: His Canvass on the Eastern Shore-A Strong Speech at Cape Charles," The Sun (Baltimore), September 28, 1896; “'The Masses and the Asses': Rev. Thomas Dixon Classifies the People and Scoffs at the Suggestion of a Social Revolution," The Sun (Baltimore), February $11,1897$.
} 
movement he saw emerging in the late-1880s and early-1890s would never materialize.

To the dismay of portion of his congregation, Dixon denounced Bryan from the pulpit. ${ }^{440}$ Bryan's "fifty three cent dollar plan" Dixon argued, would cause civil war and increased unemployment, allowing the nation to fall into anarchy. ${ }^{441}$

In Dixon's second and third shifts, he altered the central focus of his patriotic millennial vision and adopted an anti-equality, pro-segregation, and pro-colonization argument for ensuring national unity. Dixon's second shift, from 1897 to 1898 , redefined the foundation of his patriotic millennial vision by inextricably linking the roots and future of America's global power to its individual Anglo-Saxon citizens and the continued preservation of its whiteness. Further, Dixon's works in this second change demonstrate the rising dominance of Darwinian racial hierarchies in his ideals. Dixon's works illustrate that his third ideological shift built on this white-centric mentality. By 1901, Dixon's ideology opposed many of the ideas he previously championed in the early-1890s and his main emphasis became the intertwined nature of sectional tensions and issues of race, and how to solve these problems. A militant Anglo-Saxonism permeated his ideology and he no longer emphasized the role of the federal government in driving socio-economic change. Dixon still viewed citizens' activism and Christian morality as essential elements in bettering the country, but envisioned a racially stratified society for the future. He became a public advocate of racial separation, colonization,

\footnotetext{
440 "'Preached Hissed, Shouts of 'That's False," 'You Are Wrong': Rev. Thomas Dixon, Jr. Condemned Candidate Bryan," Boston Daily Globe, September 7, 1896; "Hisses for a Preacher: The Rev. Thomas Dixon's Political Sermon Causes Excitement," New York Times, September 7, 1896.

441 “A Sermon Hissed and Applauded,” The Sun (Baltimore), September 8, 1896; "Pulpit Roast for Mr. W.J. Bryan: Scored by the Rev. Thomas Dixon for Advocating Rascality," Chicago Daily Tribune, September 7, 1896; "A Draft Toward Anarchy: The Rev. Thomas Dixon Addresses a Somewhat Disorderly Audience," New York Times, October 5, 1896.
} 
and male, whites-only voting privileges as the immediate solutions to national ills. For him, any other options risked weakening the nation's Anglo-Saxon foundation.

Dixon's second change occurred after 1896, when his focus on national solidarity and sectional reconciliation intertwined with the theory of Anglo-Saxonism. Dixon's sermons in the period surrounding the war demonstrate the way that Anglo-Saxonism influenced his vision of the new nation's future. For Dixon, the war's end solidified a pre-war assumption that the U.S. was becoming a world power, and that God had destined the nation for this path. He envisioned new, globally powerful America from spreading its message of democracy through expansion. ${ }^{442}$ Spreading the American flag, for Dixon, was the equivalent of disseminating Christianity, because "the stars and stripes are themselves a gospel" and "its progress marks the footprint of God."443 Intervention in Cuba was a matter of "duty to country, humanity, and God."444 It would ensure America's future position as the leader of "the world to peace, freedom and justice," according to Dixon. ${ }^{445}$ Since the American Revolution, the U.S. spread this message through expansion, which Dixon viewed as "the ordinance of our national life.,"446 America's divine destiny to be the "most powerful and influential nation in the world,"

\footnotetext{
${ }^{442}$ Dixon, "New Fourth of July," in Dixon's Sermons: Delivered in the Grand Opera House, New York, 1898-1899 (New York: F.L. Bussey, 1899), 40.

${ }^{443}$ Dixon, "The Mightiest Navy in the World," 31; Thomas Dixon, "New Fourth of July," Dixon's Sermons: Delivered in the Grand Opera House, New York, 1898-1899 (New York: F.L. Bussey, 1899), 41. ${ }^{444}$ Ibid.

445 “A Red-Hot War Speech: Rev. Thomas Dixon Makes a Glowing Address in Raleigh," The Sun, July 9, 1898.

${ }^{446}$ Dixon, "New Fourth of July," 40.
} 
was linked closely to its Anglo-Saxon citizens. "447 "The future of the human race" depended on Anglo-Saxon development and control of the tropics. ${ }^{448}$ Spreading the American flag, for Dixon, was the equivalent of disseminating Christianity, because "the stars and stripes are themselves a gospel" and "its progress marks the footprint of God." 449 Dixon, "an expansionist with a big E," favored "keeping all of the territory we have got, and of taking in all we can keep." 450 He believed the country could use "rich territory going to waste in any part of the world, which America could civilize and govern. ${ }^{451}$ "This war in the Philippines is a righteous war," Dixon maintained, "carried on in the interest of civilization, Christianity and American rights, and every good citizen ought to support the administration, while it is fighting it out."452 He ridiculed the idea that colonized peoples deserved voting rights, arguing that Jefferson's belief in "all government derived their power from the consent of the governed" could not apply to the modern period. ${ }^{453}$ Civilizing "lesser" peoples, in his formulation, was part of America's global path to greatness.

\footnotetext{
447 Thomas Dixon, "Destiny of America," in Dixon's Sermons: Delivered in the Grand Opera House, New York, 1898-1899 (New York: F.L. Bussey, 1899), 77-79.

${ }^{448}$ Thomas Dixon, “Kitchener and Dewey," in Dixon's Sermons: Delivered in the Grand Opera House, New York, 1898-1899 (New York: F.L. Bussey, 1899), 85.

${ }^{449}$ Dixon, "The Mightiest Navy in the World," 31; Dixon, "New Fourth of July," 41.

450 "A Righteous War: Rev. Thomas Dixon's View of the Contest in the Philippines," The Topeka State Journal (Topeka, Kansas), October 5, 1899.

${ }^{451}$ Ibid.

${ }^{452}$ Ibid.

${ }^{453}$ Ibid.
} 
The most significant result of the Spanish American War, Dixon argued, was that fighting the war united the American people, "wiped out the scars of... civil strife" leftover from the Civil War and exacerbated by industrialization. ${ }^{454}$ Citizens from all regions had united in the war effort, and Dixon maintained this was crucial in "fulfilling the destiny set before this Nation." ${ }^{, 45}$ Throughout the war, Dixon asserted, a new form of patriotism developed, "not the patriotism that fights for selfish rights and avaricious claims, but the patriotism of humanity that fights for human brotherhood and universal liberty."456 New patriotism formed one part of the new era after the end of the SpanishAmerican War. ${ }^{457}$ Dixon interpreted the war as the beginning of an era run by "a new idea" and "a new ideal of manhood," rescuing the nation from thirty years of domination "by the commercial spirit and the almighty dollar that... overshadowed patriotism and all else." ${ }^{458}$ The war had eliminated sectional tensions and united the citizens behind a common country. ${ }^{459}$ "After the glorious end of the war," Dixon maintained, "the country awoke to find... a united country and a united nation was no longer a vague dream, but an accomplished fact." ${ }^{, 460}$

\footnotetext{
454 "The Duty of Christians: The Rev. Dr. Kittredge says the War Against Spain is a Holy Uprising," New York Times, May 9, 1898.

${ }^{455}$ Ibid.

${ }^{456}$ Ibid.

457 “A Red-Hot War Speech: Rev. Thomas Dixon Makes a Glowing Address in Raleigh,” The Sun, July 9, 1898.

${ }^{458}$ Ibid.

459 "Some Lessons of the War: Sermon by the Rev. W.S. Crowe at the Church of the Eternal Hope," New York Times, September 19, 1898.

460 "'New America' a Fact: Mr. Thomas Dixon, Jr. Says the Spanish War United It," The Sun, November $12,1902$.
} 
In Dixon's eyes, race played a crucial role in uniting the nation during and after the Spanish-American War. America's divine destiny to be the "most powerful and influential nation in the world," was linked closely to its Anglo-Saxon citizens. ${ }^{461}$ "The future of the human race" depended on Anglo-Saxon development and control of the tropics. ${ }^{462}$ He foresaw "the cementing together of the English-speaking races," a "union of all Anglo-Saxondom" to "march in the cause of right and humanity" and coalesce against the "Latin Race." ${ }^{463}$ Such an alliance "would be the fulfillment of the dreams of the great souls of our race for the past hundred years. It would be the greatest event in the history of the evolution of government since the Declaration of American Independence." ${ }^{464}$ Dixon believed a formal alliance of Anglo-Saxon nations could emerge victorious from future battles. ${ }^{465}$ Though no such formal alliance materialized, the war strengthened the imagined racial and ethnic ties of whiteness present in AngloSaxonism. ${ }^{466}$ Dixon predicted that this brotherhood of white Americans would be the bedrock of the nation's future.

Dixon believed that the post-Spanish-American War months represented a moment of vast importance for the developing new nation. It provided America an

\footnotetext{
${ }^{461}$ Dixon, "Destiny of America," 77-79.

${ }^{462}$ Dixon, "Kitchener and Dewey," 85.

463 "The Benefits of the War," New York Times, May 9, 1898; "Duty of a Nation," Chicago Tribune, April 18, 1898; ““'Will Revive Patriotism: Rev. Edwin Heyl Delk Thinks the War Will Have a Good Effect," Washington Post, April 25, 1898.

${ }^{464}$ Thomas Dixon, "The Anglo-Saxon Alliance," in Dixon's Sermons: Delivered in the Grand Opera House, New York, 1898-1899 (New York: F.L. Bussey, 1899), 7.

${ }^{465}$ Dixon, "The Anglo-Saxon Alliance," 7.

${ }^{466}$ Miller, From Liberation to Conquest, 190.
} 
opportunity to answer serious issues of class, labor, race, and national identity. For Dixon, as well as for the "new" America, the turn-of-the-century represented a period of both change. By the end of 1898, Dixon decided that the church no longer held its previous sway over large portions of American culture. He resigned to spread his messages through a different venue. Protestantism had not changed enough to please Dixon. The "organic Christian Union" Dixon envisioned upon establishing The People's Church in 1895 did not materialize properly. ${ }^{467}$ The independent ministry "disappointed" Dixon; he maintained that all his messages delivered as pastor at the People's Church would have been more effective in a Baptist pulpit. ${ }^{468} \mathrm{He}$ firmly believed the church was deteriorating, and his messages were less effective in such an environment. ${ }^{469}$ This "disintegration of organic church life," according to Dixon's last published sermon, was part of God's plan to establish a divine just social order in America. ${ }^{470}$ It also meant that he could not reach the masses through the pulpit. Dixon left New York City, as a resident, to return south. He moved his family to a four hundred acre waterfront colonial estate in Virginia, named "Dixondale," where he began farming and lecturing in a variety of venues. ${ }^{471}$

\footnotetext{
467 “No Organic Christian Union. Rev. Dr. Thomas Dixon, Jr., Resigns His Work in New York City,” The Atlanta Constitution, January 16, 1899.

468 "No Organic Christian Union. Rev. Dr. Thomas Dixon, Jr., Resigns His Work in New York City," The Atlanta Constitution, January 16, 1899; "Rev. Thomas Dixon Resigns: Works of Independent Ministry, He Says, Has Been Disappointing," The Washington Post, January 16, 1899; Thomas Dixon, "Resignation," 155.

${ }^{469}$ Dixon, "Resignation," in Dixon's Sermons: Delivered in the Grand Opera House, New York, 1898-1899 (New York: F.L. Bussey, 1899), 154-155.

${ }^{470}$ Ibid.

471 “Will Lose Thomas Dixon,” The Times (Richmond, Virginia), July 11, 1899; "Rev. Thomas Dixon," The Richmond Dispatch, September 6, 1900.
} 
Lecturing full time allowed him to see multiple regions of the post-SpanishAmerican War country. Dixon delivered spoken pieces in Kentucky, Georgia, Texas, Nebraska, Virginia, Maryland, Kansas, Colorado, Wisconsin, Illinois, and Louisiana, and more. ${ }^{472}$ The former minister continued spreading messages about reforming corruption and the nation's divine destiny as a global, Anglo-Saxon power on various lecture circuits. Dixon's message was well received by many Americans, and he became one of the best-paid lecturers. ${ }^{473}$ Despite his "overgrown boy" appearance, Dixon's "most brilliant display of oratory firework" combined "humor, pathos, and dramatic power as no other man of this day." "474 "Universally regarded as the most perfect master of dramatic oratory in this country," "The Platform King of America" often spoke to crowds of hundreds, sometimes thousands. ${ }^{475}$ As a lecturer, Dixon maintained his seminal themes by focusing on race, sectionalism, economic issues, religion, and the nation, while

\footnotetext{
472 "Rev. Tom Dixon, Jr.," Virginian-Pilot (Norfolk, Virginia), June 8, 1899; "Dixon at Danville," The Central Record (Lancaster, Kentucky), October 26, 1899; "In the Local Field," The Atlanta Constitution, December 3, 1896; "Pocomoke City," The Sun (Baltimore), November 19, 1897; "The Summer Assemblies for 1897," The Chautauquan: A Weekly Newsmagazine 26, no. 2 (November 1897): 234-239; "Beatrice Chautauqua-Low Rates via the Burlington," The Nebraska Advertiser, June 21, 1901; "Other Chautauqua Assemblies," The Chautauquan: A Weekly Newsmagazine 33, no. 4 (July 1901): 33-52; "Summer Assemblies for 1902," The Chautauqua: A Weekly Newsmagazine 36, no. 1 (October 1902): 98-105; "Display Ad 11," Chicago Daily Tribune, January 25, 1903.

473 “With Some Authors You Have Known,” The Atlanta Constitution, January 11, 1903.

474 "What Dixon Is," The Central Record (Lancaster, Kentucky), October 26, 1899; "Dixon at Danville," The Central Record (Lancaster, Kentucky), October 26, 1899.

475 "Rev. Tom Dixon, Jr.," Virginian-Pilot (Norfolk, Virginia), June 8, 1899; "Brambleton Ward," Virginian-Pilot (Norfolk), June 8, 1899; "Mountain Chautauqua: Crowds Gather from a Distance to Hear the Lectures and Enjoy the Music," The Sun (Baltimore), August 10, 1897; "Barnesville to Hear Bryan Today," The Atlanta Constitution, July 4, 1899; "Raps at Woman Suffrage: Rev. Thomas Dixon, Jr. Says that Married Life and the Ballot Cannot Survive Together for a Century," The Boston Globe, November 6, 1900; "Takes Fools as His Subject: New York Minister Delivers Address at Monona Lake AssemblyVisitors to Preach Today," Chicago Daily Tribune, June 21, 1901; "Other Chautauqua Assemblies," The Chautauquan: A Weekly Newspaper Magazine 35, no. 4 (July 1902): 399.
} 
criticizing corruption and efforts to expand voting rights or ballot protections. Several of the lectures were standbys from his earlier Chautauqua ventures, such as "Backbone, the Foundation of Anglo-Saxon Character," "Fools, or the School of Experience, a Satire," "The Modern Babylon, a Study of Modern Municipal Corruption," "The Larger Church," and "The Almighty Dollar, or the Lights and Shadows of New York." his support of expansionism, like "The New American, a new war lecture advocating the larger America," and "The Imperial Man."

When he left his position as a minister in 1899 , Dixon was convinced the Spanish-American War had successfully united the country behind a banner of nationalism and global destiny, creating a "New America." While lecturing on various lecture circuits at the turn-of-the-century, Dixon experienced the new nation firsthand. His predictions of American unity failed to materialize. The post-Spanish-American War debate over citizenship caused Dixon to conclude there was no exisiting singular national identity, after all. Instead, he saw a country still plagued by the Southern Problem, the Race Problem, and the Labor Problem, as it had been in the 1890s. The most pressing problems facing this new nation, Dixon concluded, were the continuation of sectional animosities and racial tensions.

Dixon's third major ideological change was driven by this national debate over citizenship. Since Dixon equated America's power with the white racial purity, he argued that only a pro-segregation, pro-colonization, and anti-universal suffrage policy would be able to solve the nation's racial and sectional problems. The only people he

\footnotetext{
476 “Two Essentials,” Alkahest Magazine 7 (July 1900).
} 
supported as eligible for suffrage rights were white, male, and educated. Dixon opposed ladies' suffrage, believing it threatened to undermine the nation's power in a similar way as black suffrage. Women's suffrage threatened the nation's future, he maintained, and ladies were not guaranteed voting rights as American citizens. Thomas Dixon believed status as a tax-paying citizen did not entail voting privileges: "Taxes," he maintained, "are paid for the protection of life and property, not for the right to vote." The "peculiar power" of the ballot, to act as a political "bayonet," in his eyes, belonged only to white American men. ${ }^{477}$ Women, in his opinion, were "not physically strong enough to take part in life's battles," and could not "stand the strain of voting." 478 To pit husband against wife would only result in conflict, with women "losing many of the advantages she now possesses."479 These privileges included "better protection of person under the criminal laws" and "more courtesy and care in social treatment." 480 Gender equality in suffrage also threatened to destroy the institution of marriage, for "marriage life and the ballot cannot survive together for a century." Further, bringing females "to the halls of legislation" could lead to "the power of sex attraction" causing "the worst corruption the world has seen."481 The repercussions would also undermine the nation's future population, Dixon suggested. Should women leave their "proper sphere," the home, they

\footnotetext{
477 "Raps at Woman Suffrage: Rev. Thomas Dixon, Jr. Says that Married Life and the Ballot Cannot Survive Together for a Century," The Boston Globe, November 6, 1900.

478 “Mrs. Gougar Mr. Dixon's Equal: A Naïve Argument with Which She Demonstrated It," New York Times, July 13, 1896.

${ }^{479}$ Ibid.

480 "Raps at Woman Suffrage: Rev. Thomas Dixon, Jr. Says that Married Life and the Ballot Cannot Survive Together for a Century," The Boston Globe, November 6, 1900.

${ }^{481}$ Ibid.
} 
would become "unsexed... she would not be able to fulfill the great purpose of creation, the reproduction of mankind." ${ }^{, 82}$ Dixon's ideal American woman would "use her heart power, and not horse power." ${ }^{\text {"483 }}$ He believed Southern white women personified this dream. "Hope lies in the Southern woman and her ideals," Dixon asserted, "with the instincts that should be in the heart of every member of the great Aryan race." ${ }^{484}$

To Dixon, the idea of equal citizenship perpetuated racial tensions and posed a threat to the new nation's progress. Eliminating tensions was of crucial importance to ensuring America's future success, and "The Race Question," oftentimes, intersected with the Southern one. The Race Question, in Dixon's interpretation, was the issue of African Americans' potential future in the new nation. One prominent source of racial animosity stemmed from African Americans' participation in politics. The political power of black voters enabled the current corruption of the system, according to AngloSaxonist logic. Dixon maintained that nonwhite voters also paralyzed the South from focusing on other political issues, since "the Southern people do not vote on anything except on the question of the preservation of their race and civilization." ${ }^{485}$ Dixon interpreted Wilmington Riots of 1898 as one such product of interracial politics. Wilmington, North Carolina possessed a majority black population and maintained a

\footnotetext{
482 “Mrs. Gougar Mr. Dixon's Equal: A Naïve Argument with Which She Demonstrated It," New York Times, July 13, 1896.

483 "Raps at Woman Suffrage: Rev. Thomas Dixon, Jr. Says that Married Life and the Ballot Cannot Survive Together for a Century," The Boston Globe, November 6, 1900.

484 "Danger, Says Mr. Dixon: Author Gives Straight Talk on the Race Question," The Sun (Baltimore), March 12, 1906.

${ }^{485}$ Thomas Dixon, "A Friendly Warning to the Negro," in Dixon's Sermons: Delivered in the Grand Opera House, New York, 1898-1899 (New York: F.L. Bussey, 1899), 6.
} 
functional biracial Fusionist government. After failing to win the election of 1898, white supremacists violently seized power, spawning violent riots throughout the city. In direct response to the violence at Wilmington, Dixon delivered a sermon titled "A Friendly Warning to the Negro."

The "Friendly Warning" demonstrates the way Dixon viewed larger racial ideologies throughout the country, and reinforced his earlier belief in black enfranchisement as dangerous. He justified his stance by arguing that a larger, national racism existed throughout the nineteenth century. The North did not fight the Civil War to free African Americans, he maintained, their "emancipation was an accident of war" resulting from Lincoln's decision to "strike the South a deadly blow an save the nation." "486 Black enfranchisement represented a "crime of colossal proportions" and an act of personal vengeance against the South rather than the reflection of national attitudes. Dixon insisted that race prejudice plagued the nation, rather than just the South. Northern whites no longer provided African Americans the "artificial support" of the previous thirty years, as the realities of industrialization made economic matters more important. In his observations, "the bitterest discrimination against the negro in America," could be found in "the economic discrimination in the North." ${ }^{\text {"47 }}$ There, blacks' employment options were limited to menial positions. ${ }^{488}$ In the South, however, "the negro is welcomed as a land owner... enters every conceivable line of economic

\footnotetext{
${ }^{486}$ Dixon “A Friendly Warning to the Negro," 116-119.

${ }^{487}$ Ibid.

${ }^{488}$ Ibid.
} 
development... and his patrons are Southern white men." "Race prejudice," however, was "a terrible fact, North and South," Dixon felt needed immediate attention. ${ }^{489}$

This piece outlines Dixon's established racial roles for the post-Spanish-American War new nation. The reunification of the sections and creation of a singular nation, in his argument, had placed America on a trajectory diminishing blacks' political importance. The war made it "impossible in the future for the negro... to ever arouse this nation upon the issue of alleged disloyalty because of race conflicts in the South. ${ }^{, 490}$ African Americans were now responsible to "work out his own salvation with fear and trembling. ${ }^{, 491}$ Dixon claimed that abandoning political activism was in the "best interest" of American blacks. He warned African Americans to discontinue hopes of integration into the political and social structure of the nation, arguing the race's destiny was "not to govern the Anglo-Saxon." Also, he insisted African Americans "must get out of politics and go into business" to enrich their lives. ${ }^{492}$ Their continued participation would only perpetuate racial hatreds and hinder a unified, white America from achieving its divine destiny. He expected black Americans to "become friends" with Southern whites, and labor under their supervision, to succeed, or to migrate West, to Puerto Rico, Cuba, or the Philippines. ${ }^{493}$ America's future depended on blacks' occupation of their

\footnotetext{
${ }^{489}$ Dixon, “A Friendly Warning to the Negro," 117-120.

${ }^{490}$ Ibid.

${ }^{491}$ Ibid.

${ }^{492}$ Ibid.

${ }^{493}$ Ibid.
} 
"proper" place, he argued, and the Republic's "future progress" depended "not upon the expansion of suffrage, but upon its intelligent restriction. ${ }^{, 494}$

Dixon viewed anti-black sentiment and segregation as "the instinct of selfpreservation." The very presence of African Americans, he argued, made blacks a "menace to one element of the Americans' strength—his racial integrity." ${ }^{495}$ Potential race mixing alarmed Dixon and the majority of whites across the nation. "The Mulatto Problem," the question of the rights of mixed-race individuals, and of defining at what point these individuals could be considered "white," formed another element of the race discussion. ${ }^{496}$ Mixed-race individuals complicated the citizenship question, occupying the gray area of the black-white color line. Their presence presented further challenges to smoothing racial tensions. ${ }^{497}$ Dixon viewed mixed-race peoples as a serious threat to national power and purity. He sought to ban miscegenation throughout the nation, imploring Northern states to "pass laws prohibiting forever marriage between the races.",498 "The time is ripe," he declared, "for the first step that will result in blotting out all remembrance of that awful possibility—social amalgamation." 499

\footnotetext{
${ }^{494}$ Dixon, “A Friendly Warning to the Negro," 119.

495 "Kinds of Race Prejudice: They Result, Says Dr. Dixon, from Fear of Superior Powers and from the Instinct of Self-Preservation," Boston Daily Globe, June 9, 1903.

${ }^{496}$ Ring, The Problem South, 200-204.

${ }^{497}$ Ibid.

498 "Danger, Says Mr. Dixon: Author Gives Straight Talk on the Race Question," The Sun (Baltimore), March 12, 1906.

${ }^{499}$ Ibid.
} 
In some ways, Dixon's racial ideologies shared characteristics with those of other white, Progressive Americans. Like Theodore Roosevelt and the New Nationalist Progressives, he believed in assimilating white immigrants into a larger Americanism through a system of educational citizenship. Dixon's fervent insistence that Anglo-Saxon characteristics, such as "backbone," "character," "principle," and "conviction," underscored the race's place as America's top tier. ${ }^{500}$ Dixon also shared, with Teddy Roosevelt and other Progressives, a belief that white Americans owed African Americans a "square deal," defined as "equality of opportunity." overlapped significantly with the Progressive version of the ideal America, his proposed solutions to race issues deviated from the norm, which relied on Jim Crow segregation and educational efforts. Segregation's conditions created "a black nation growing up inside of a white nation," which defied "our whole theory of government, where all men are presumed to be free and equal." 502 For Dixon, "colonization" provided the "only real solution to the problem" of race. ${ }^{503}$ He viewed African American labor as unsatisfactory, and the "moral condition of the Negro" as "worse now than it was before the war.",504 "Education" did not provide the answer, having "not benefitted the colored man as a

\footnotetext{
500 “An Address on Backbone: Rev. Thomas Dixon, Jr., At the Lyceum," The Scranton Tribune (Scranton, Pennsylvania), December 11, 1901.

501 “The Negro a Menace Says Thomas Dixon,” New York Times, June 9, 1903.

502 “An Address on Backbone: Rev. Thomas Dixon, Jr., At the Lyceum,” The Scranton Tribune (Scranton, Pennsylvania), December 11, 1901.

${ }^{503}$ Ibid.

${ }^{504}$ Ibid.
} 
race." 505 Instead, in Dixon's view, education "bred discontent" amongst African Americans by "allowing him to deceive himself." 506 White Americans' "present attitude of hypocrisy," he concluded, prevented African Americans from obtaining the "square deal" owed them. ${ }^{507}$ Blacks would never be able to "assimilate... or meet on a plane of equality" within the nation's borders. ${ }^{508}$ The only solution was to establish a "free black republic" in Africa. ${ }^{509}$ Immigrants, in this vision, provided a welcome replacement for African American labor. ${ }^{510}$

Though he shared many ideals with the Progressives, such as the importance of education and eliminating corruption, Dixon did not support the national government's renewed focus on the South or the idea that the road to national success lie in federal efforts to reform the South. Dixon viewed attempts to interfere with the South's social system as an overreach of government power, and compared the period to the events of Reconstruction. Dixon's attacks on Ogdenism demonstrate his turn against federal intervention in the South, and parallel critiques made by other white right-leaning Southerners. The presence of Northern interests in Southern educational affairs raised Dixon's, and many other Southern whites', suspicions. He suggested it lacked concern

\footnotetext{
505 “An Address on Backbone: Rev. Thomas Dixon, Jr., At the Lyceum," The Scranton Tribune (Scranton, Pennsylvania), December 11, 1901.

506 “'New America' a Fact: Mr. Thomas Dixon, Jr., Says the Spanish War United It,” The Sun (Baltimore), November 12, 1902; "The Past and Future of Liberia," The Sun (Baltimore), August 27, 1905.

507 “The Past and Future of Liberia," The Sun (Baltimore), August 27, 1905.

508 “The Past and Future of Liberia," The Sun (Baltimore), August 27, 1905; "An Address on Backbone: Rev. Thomas Dixon, Jr., At the Lyceum," The Scranton Tribune (Scranton, Pennsylvania), December 11, 1901.

509 “The Past and Future of Liberia," The Sun (Baltimore), August 27, 1905.

510 “Will Be Riots Here-Dixon,” New York Times, September 24, 1906.
} 
for the South, with "its headquarters in a negro equality restaurant on Broadway," and a leader whose "interests have always been with the negro." ${ }^{\text {"11 }}$ Their efforts to fix a region they didn't understand equated to "scalawag commercialism.",512 Ogden and other Northern philanthropists, Dixon maintained, secured power over the Southern members of the board through methods of deceit and financial control of the SEB's resources. ${ }^{513}$ Like other Southern conservative whites, Dixon also believed Ogden and the SEB possessed a secret agenda to undermine white supremacy. The SEB, in his calculations, represented "the most insidious, dangerous movement against Southern sentiment since the war." It was one of "many subtle forces," Dixon argued, threatening to "drown the national character at last in a welter of negroid mongrelism." ${ }^{\text {} 14}$ The Board's attempts to educate Southern blacks could only perpetuate national race problems. "Education," he argued, "is the chief cause of the worthlessness of the negro today" because "an educated negro believes he is above being a farm hand or a servant or working with his hands at anything." ${ }^{515}$ It turned African Americans into "monstrosities" that endangered the nation. ${ }^{516}$ He blamed progressives reformers meddling in the South, as well as black

\footnotetext{
511 "Ogden and the Negro: Thomas Dixon, Jr. on Chairmen of Southern Education Board," The Sun (Baltimore), June 8, 1905.

512 "Danger, Says Mr. Dixon: Author Gives Straight Talk on the Race Question,” The Sun (Baltimore), March 12, 1906.

513 "Ogden and the Negro: Thomas Dixon, Jr. on Chairmen of Southern Education Board," The Sun (Baltimore), June 8, 1905.

${ }^{514}$ Ibid.

515 “'New America' a Fact: Mr. Thomas Dixon, Jr., Says the Spanish War United It," The Sun (Baltimore), November 12, 1902.

516 "Preacher Predicts Race War: The Rev. Thomas Dixon Says Anglo-Saxons Will Wipe Out Race Made Into Monstrosities by Education," Chicago Daily Tribune, February 23, 1903.
} 
leaders like Booker T. Washington, whose plans "bred discontent among the race and were doing far more harm than good." ${ }^{517}$ Ogden's "educational trains Southward," Dixon asserted, were "nothing but instruments for instilling his abominable doctrines into Southern minds. ${ }^{, 518}$

If Progressives continued emphasizing educational reform that championed equality, Dixon inferred, national reconciliation would never be possible. It seemed the Spanish-American War had not solved the Race and Southern Problems, after all. Instead, it had brought these issues to the forefront of national debate. The argument over the definition of citizenship and its privileges intensified throughout the first decades of the twentieth century. To Dixon, the nation was failing to protect its racial purity. Instead, it chose to squabble over Southern education, racial equality, and citizenship. The current state of affairs, he argued, could only lead to inevitable "race war" in which the Anglo-Saxon race would "prove its superiority by wiping the negro from the country." ${ }^{519}$ Sectional reconciliation and Anglo-Saxon unity were the only ways for white Americans to maintain their social status quo.

Dixon's Reconstruction Trilogy demonstrates the conservative white supremacist element reacting to these trends. From 1902 to 1907, Dixon published three books comprising the Reconstruction Trilogy, in which he incorporated personal history, past and present politics, race, gender, and sectionalism into an argument for a nation united

517 “'New America' a Fact: Mr. Thomas Dixon, Jr., Says the Spanish War United It," The Sun (Baltimore), November 12, 1902.

518 "Danger, Says Mr. Dixon: Author Gives Straight Talk on the Race Question,” The Sun (Baltimore), March 12, 1906.

519 "Preacher Predicts Race War: The Rev. Thomas Dixon Says Anglo-Saxons Will Wipe Out Race Made Into Monstrosities by Education," Chicago Daily Tribune, February 23, 1903. 
behind a white identity. In these novels, he weaves a complicated, masculine, ethnically oriented vision of American nationalism and the nation's history. The lessons Dixon garnered as a child, in college, and as a minister in Northern cities, shine visibly through the Reconstruction Trilogy's style and narrative. In the events of Reconstruction, he saw multiple parallels to the reformism of the turn-of-the-century; the time was ripe for a national discussion and solution to the race problem. Without this answer, Dixon feared, the nation's power could fade. 


\section{Chapter Four}

\section{The Reconstruction Trilogy (1902-1907)}

Dixon's first three Southern-focused novels, known as the Reconstruction Trilogy, published from 1902-1907, appeared for sale within the context of continuing debates over citizenship, federal government power, and national unity. By drawing parallel lines between the historical events of Reconstruction to the socio-political climate at the turn-of-the-century in the novels, Dixon intended to remedy sectionalism, offer a warning about the dangers of too much federal power in the states, and propose colonization and segregation as solutions to the race problem. Dixon was not alone in his turn-of-the-century shift to constitutional conservatism. ${ }^{520}$ He was also one of many intellectuals using historical events as evidence in the larger turn-of-the-century debate over citizenship, the place of the South in the nation at large, and the reach of government power. This chapter traces the events of Reconstruction, surveys its different historiographical interpretations in the early-1900s, and analyzes the plot, characters, and themes presented in Dixon's trilogy of novels.

The events of Reconstruction and its many interpretations in American memory at the turn-of-the-century are crucial to understanding Dixon's first trilogy. ${ }^{521}$ After the end

\footnotetext{
${ }^{520}$ More information about constitutional conservatism in the U.S. before World War I, see: Joseph Postell and Johnathan O'Neill, eds., Toward an American Conservatism: Constitutional Conservatives During the Progressive Era (New York: Palgrave Macmillan, 2013); Gerard N. Magliocca, The Tragedy of William Jennings Bryan: Constitutional Law and the Politics of Backlash (New Haven: Yale University Press, 2011); and Gabriel Kolko, The Triumph of Conservatism, 1900-1916 (New York: Free Press of Glencoe, 1963).

${ }^{521}$ On the events of Reconstruction, and its impact on national life in the nineteenth century, see: Mark Wahlgren Summers, The Ordeal of The Reunion: A New History of Reconstruction (Chapel Hill: University of North Carolina Press, 2014); Douglas R. Egerton, The Wars of Reconstruction: The Brief, Violent
} 
of the American Civil War, society's future shape and structure was largely

undetermined, leaving a slew of unanswered questions: What would become of former

Confederates? Would they become American citizens once again? If so, when? What

would happen in the South? How would emancipation be enacted throughout society at

large? What role would African Americans play in the nation's future? Would they have

full rights as citizens? What would be the economic system in the South, and the nation?

Would the nation ever be reunited, peacefully? The country also struggled with questions

about the meaning of equality, of citizenship, and of the future path of the country.

Debates over the size and scope of federal power, as well as about constitutional equality,

whether it guaranteed a citizenship with voting rights, with social rights, or with both,

dominated politics during Reconstruction (1865-1877), as Congress attempted to work

History of America's Most Progressive Era (New York: Bloomsbury Press, 2014); James Oakes, Freedom National: The Destruction of Slavery in the United States, 1861-1865 (New York: Norton, 2013); Gregory P. Downs, Declarations of Dependence: The Long Reconstruction of Popular Politics in the South, 18611908 (Chapel Hill: University of North Carolina Press, 2011); Paul A. Cimbala and Randall Miller, eds., The Great Task Remaining Before Us: Reconstruction as America's Continuing Civil War (New York: Fordham University Press, 2010); Stephanie McCurry, Confederate Reckoning: Power and Politics in the Civil War South (Cambridge: Harvard University Press, 2010); Richard L. Hume and Jerry B. Gough, Blacks, Carpetbaggers, and Scalawags: The Constitutional Conventions of Radical Reconstruction (Baton Rouge: Louisiana State University Press, 2008); Andrew L. Slap, The Doom of Reconstruction: The Liberal Republicans in the Civil War Era (New York: Fordham University Press, 2007); Edward J. Blum, Reforging the White Republic: Race, Religion, and American Nationalism, 1865-1898 (Baton Rouge: Louisiana State University Press, 2006); Anne Sarah Rubin, A Shattered Nation: The Rise and Fall of the Confederacy, 1861-1868 (Chapel Hill: University of North Carolina Press, 2005); Melinda Lawson, Patriot Fires: Forging a New American Nationalism in the Civil War North (Lawrence: University Press of Kansas, 2002); Nancy Cohen, The Reconstruction of American Liberalism, 1865-1914 (Chapel Hill: University of North Carolina Press, 2002); David W. Blight, Race and Reunion: The Civil War in American Memory (Cambridge: Belknap Press of Harvard University Press, 2001); Scott Reynolds Nelson, Iron Confederacies: Southern Railways, Klan Violence, and Reconstruction (Chapel Hill: University of North Carolina Press, 1999); Eric Foner, Reconstruction: America's Unfinished Revolution, 1863-1877 (New York: Harper and Row, 1988); Nell Irvin Painter, Standing at Armageddon: The United States, 1877-1919 (New York: W.W. Norton, 1987); Dan T. Carter, When the War was Over: The Failure of SelfReconstruction in the South, 1865-1867 (Baton Rouge: Louisiana State University Press, 1985); George C. Rable, But There Was No Peace: The Role of Violence in the Politics of Reconstruction (Athens: University of Georgia Press, 1984); and John Hope Franklin, Reconstruction: After the Civil War (Chicago: University of Chicago Press, 1961). 
out the specifics details of fitting newly freed African Americans and former

Confederates into the Union: What was the meaning of equality, both socially and

politically? ${ }^{522}$ Did citizenship guarantee voting rights? What responsibilities did the

federal government have to protect these rights?

With Congress not scheduled to reconvene until December, President Andrew

Johnson controlled the answers to these questions during the months following the

Confederate surrender at Appomattox in April 1865. A staunch Democrat, Johnson

believed that wartime Republicans had intentionally expanded federal government's

\footnotetext{
${ }^{522}$ For more information regarding the Reconstruction Era debate over citizenship and equality, see: E. Baker and Brian Kelly, eds., After Slavery: Race, Labor, and Citizenship in the Reconstruction South (Gainesville: University Press of Florida, 2013); Carole Emberton, Beyond Redemption, Race, Violence, and the American South after the Civil War (Chicago: University of Chicago Press, 2013); Stephen Kantrowitz, More Than Freedom: Fighting for Black Citizenship in a White Republic, 1829-1889 (New York: Penguin, 2012); Faye E. Dudden, Fighting Chance: The Struggle over Woman Suffrage and Black Suffrage in Reconstruction America (New York: Oxford University Press, 2011); Hugh Davis, "We Will Be Satisfied With Nothing Less": The African American Struggle for Equal Rights in the North During Reconstruction (Ithaca: Cornell University Press, 2011); Elizabeth Reilly, ed., Infinite Hope and Disappointment: The Story of the First Interpreters of the Fourteenth Amendment (Akron: University of Akron Press, 2011); Kate Masur, An Example for All the Land: Emancipation and the Struggle over Equality in Washington, D.C. (Chapel Hill: University of North Carolina Press, 2010); Hannah Rosen, Terror in the Heart of Freedom: Citizenship, Sexual Violence, and the Meaning of Race in the Postemancipation South (Chapel Hill: University of North Carolina Press, 2009); Mitchell Snay, Fenians, Freedman, and Southern Whites: Race and Nationality in the Era of Reconstruction (Baton Rouge: Louisiana State University Press, 2007); Charles W. Calhoun, Conceiving a New Republic: The Republican Party and the Southern Question, 1869-1900 (Lawrence: University Press of Kansas, 2006); Joseph A. Ranney, In the Wake of Slavery: Civil War, Civil Rights, and the Reconstruction of Southern Law (Westport: Praeger, 2006); Carol A. Horton, Race and the Making of American Liberalism (New York: Oxford University Press, 2005); Steven Hahn, A Nation Under Our Feet: Black Political Struggles in the Rural South from Slavery to the Great Migration (Cambridge: Belknap Press of Harvard University Press, 2003); Heather Cox Richardson, The Death of Reconstruction: Race, Labor, and Politics in the Post-Civil War North, 1865-1901 (Cambridge: Harvard University Press, 2002); Jane Dailey, Glenda Elizabeth Gilmore, and Bryant Simone, eds., Jumpin' Jim Crow: Southern Politics from Civil War to Civil Rights (Princeton: Princeton University Press, 2000); Eric Foner, Nothing But Freedom: Emancipation and Its Legacy (Baton Rouge: Louisiana State University Press, 1993); Earl M. Maltz, Civil Rights, The Constitution, and Congress, 1863-1869 (Lawrence: University Press of Kansas, 1990); Joel Williamson, The Crucible of Race: Black-White Relations in the American South Since Emancipation (New York: Oxford University Press, 1984); Lawrence Grossman, The Democratic Party and the Negro: Northern and National Politics, 1868-1892 (Urbana: University of Illinois Press, 1976); William Gillette: Right to Vote: Politics and the Passage of the Fifteenth Amendment (Baltimore: Johns Hopkins University Press, 1965); and James M. McPherson, The Struggle for Equality: Abolitionists and the Negro in the Civil War and Reconstruction (Princeton: Princeton University Press, 1965).
} 
authority, by establishing the first national tax, for example, in order to increase their party's political power. His strategy was to incorporate the former Confederacy back into the Union quickly, in order to counter the power of Republicans. Johnson designed a plan for "restoration" of the former Confederate states to the Union. It included granting amnesty to all former Confederates who took an oath of allegiance to the United States, except for high-ranking officers and property-rich men (who could apply to the President for clemency), establishing provisional governments for seven states still left undecided upon Lincoln's death, and commanded these new state bodies hold conventions aimed at rejoining the Union. To be readmitted to the U.S., former Confederate states were asked to recognize the abolition of slavery, nullify state ordinances of secession, and repudiate the Confederate war debt. All "loyal" citizens qualified to elect delegates to the conventions, including any former Confederates who had taken the required oath. ${ }^{523}$

The restoration provisional governments attempted to reinstate certain elements of the antebellum socio-political system. At the Southern state conventions of mid-1865, delegates insisted upon the importance of individual states' sovereignty, refusing to acknowledge the power of the federal government. Some states refused to repudiate secession, deny the Confederate debt, or acknowledge the Thirteenth Amendment. Several prominent, formerly Confederate leaders returned to power in the elections held under the restoration state constitutions. Throughout the South, the new governments sought to contain freedpeople in subservient labor positions via "Black Codes." Most of these rules and regulations aimed at hindering African Americans' economic and

\footnotetext{
${ }^{523}$ Richardson, West From Appomattox, 40-45.
} 
geographic mobility: requiring black Southerners to obtain an occupational license for any job outside of agriculture; requiring African American laborers to sign year-long contracts; and punishing criminal "vagrancy" (a charge often leveled at unemployed freedpeople) by binding the guilty to white property owners. ${ }^{524}$

Republicans in Congress did not share Johnson's enthusiasm for restoration, arguing it did not do enough to protect freedmen. In early-1866, they responded to the increasing number of Black Codes by rejecting Johnson's restoration plan and forming the Joint Committee on Reconstruction to explore alternate options. On the committee's recommendations, Congress passed two bills, in spite of Johnson's immediate vetoes. The first bill included provisions for expanding the Freedmen's Bureau to protect Southern blacks' rights and allocating federal funding for freedmen's schools and asylums. The second was a civil rights bill that formally declared black Americans to be citizens with all the accompanying legal privileges, effectively destroying the legality of Black Codes and granting the national government authority over civil rights cases. ${ }^{525}$ Congress also ratified the Fourteenth Amendment in June, which formally declared the states could not deny African Americans' due process or equal rights. This amendment included a clause prohibiting any former Confederate who had sworn to protect the U.S. Constitution before secession from holding public office, disqualifying many of the state officers elected under the restoration regime. ${ }^{526}$ Empowered by a newly elected Republican majority of more than $2 / 3$ in Congress, which eliminated the need for

\footnotetext{
${ }^{524}$ Richardson, West From Appomattox, 46-50.

${ }^{525}$ Ibid, 52-55.

${ }^{526}$ Ibid.
} 
Johnson's approval, Republicans pursued their Reconstruction plans. The Military

Reconstruction Act, passed in March 1867, formed the backbone of the "Radical

Republican" approach to the postwar South, which lasted until 1871. This act placed the

national government as the authority over Reconstruction, divided the ten

unreconstructed states into five military districts overseen by federal commanders, and

required the former Confederate states to hold new conventions before applying to rejoin

to the Union. The new state constitutions produced in winter 1868 stood in stark contrast

to those constructed under Johnson. They called for universal manhood suffrage, popular

election of judges and officials, eliminated property qualifications for public office,

guaranteed black rights, ended imprisonment for debt, and provided funds for schools. ${ }^{527}$

During Dixon's childhood, the period of Radical (or Congressional)

Reconstruction brought severe tensions and instability to the Piedmont regions of North

Carolina. ${ }^{528}$ Reconstruction changed the composition of North Carolinian politics. After

${ }^{527}$ Richardson, West From Appomattox, 85

${ }^{528}$ Specific details on the Civil War and Reconstruction in the state of North Carolina may be found in: Deborah Beckel, Radical Reform: Interracial Politics in Post-Emancipation North Carolina (Charlottesville: University of Virginia Press, 2011); Mark L. Bradley, Bluecoats and Tar Heels: Soldiers and Civilians in Reconstruction North Carolina (Lexington: University of Kentucky Press, 2009); Paul D. Escott, North Carolinians in the Era of the Civil War and Reconstruction (Chapel Hill: University of North Carolina Press, 2008); Judkin Browning, "Removing the Mask of Nationality: Unionism, Racism, and Federal Military Occupation in North Carolina, 1862-1865, The Journal of Southern History 71, no. 3 (August 2005): 589-620; Wayne K. Durrill, "Political Legitimacy and Local Courts: 'Politicks at Such a Rage' in a Southern Community during Reconstruction," The Journal of Southern History 70, no. 3 (August 2004): 577-602; Karin L. Zipf, "'The Whites Shall Rule the Land or Die': Gender, Race, and Class in North Carolina Reconstruction Politics," The Journal of Southern History 65, no. 3 (August 1999): 499534; Laura F. Edwards, Gendered Strife and Confusion: The Political Culture of Reconstruction (Urbana: University of Illinois Press, 1997); Jonathan Thomas Young Houghton, "The North Carolina Republican Party: From Reconstruction to the Radical Right," Ph.D. Dissertation, University of North Carolina, 1993; Robin E. Baker, "Class Conflict and Political Upheaval: The Transformation of North Carolina Politics During the Civil War," North Carolina Historical Review 69 (April 1992): 148-178; Robert C. Kenzer, "The Black Businessman in the Postwar South: North Carolina, 1865-1880," The Business History Review 63, no. 1 (Spring 1989): 61-87; Paul D. Escott, Many Excellent People: Power and Privilege in North Carolina, 1850-1900 (Chapel Hill: University of North Carolina Press, 1988); Roberta Sue Alexander, North Carolina Faces the Freedmen: Race Relations During Presidential Reconstruction, 1865-1867 
the Civil War, "plain" people began participating in North Carolinian government. Many of these men had been denied power in the antebellum years, and the Republican Party's endorsement of universal male suffrage and platform endorsing socio-economic equality attracted an interracial membership. The Republican Party became an interracial political party, as African Americans began occupying an active place in North Carolina's political landscape. Joined forces of black and middling class, white Republican voters were most evident in the Piedmont and some eastern counties, including the capital city of Raleigh. They participated in a variety of grassroots organizations, committees, and conventions, and succeeded in gaining control of the state government in 1868 .

Republicans elected William W. Holden as governor, a position he previously held in the provisional period. Fifteen Republican African American delegates attended the state constitution convention, and assisted in drafting a new document. The resulting constitution extended voting and office holding rights to all men, no matter their race or religion. ${ }^{529}$ Freedmen actively pursued political and social change during Reconstruction. Radical freedmen agitated for land confiscation and state-funded welfare programs, sometimes squatting on white-owned property, or refusing to work until their demands were met. Black men were routinely elected into office. During the $1868-1870$ session,

(Durham: Duke University Press, 1985); Gordon B. McKinney, Southern Mountain Republicans, 18651900: Politics and the Appalachian Community (Chapel Hill: University of North Carolina Press, 1978); William McKee Evans, Ballots and Fence Rails: Reconstruction on the Lower Cape Fear (Chapel Hill: University of North Carolina Press, 1967); John L. Bell, Jr., "Baptists and the Negro in North Carolina During Reconstruction," The North Carolina Historical Review 42, no. 4 (October 1965): 391-409; Roland C. McConnell, The Negro in North Carolina Since Reconstruction (New York: New York University Press, 1949); and Kenneth Edson St. Clair, The Administration of Justice in North Carolina During Reconstruction, 1865-1876 (Columbus: Ohio State University Press, 1940).

${ }^{529}$ Beckel, Radical Reform: Interracial Politics in Post-Emancipation North Carolina, 3-8; 60-62. 
more than twenty African Americans served in the state legislature. ${ }^{530}$ In North Carolina, African Americans often appeared on local ballots. Until the last decade of the twentieth century, North Carolinians consistently elected between fifteen and twenty black legislators with the exception of the 1884 General Assembly. ${ }^{531}$ Their political presence and potential power threatened the South's traditional social system and polarized its political parties.

Affiliation with either post-war party required an engagement with the issue of race. The rhetoric used by Conservatives in the state elections of 1868 demonstrates the myriad of ways race remained at the forefront of politics. The Conservative Party, known as the Democratic Party after 1870, opposed the Republicans' racial egalitarianism. Conservatives sold their party as the protector of white republicanism. This republicanism was rooted in antebellum conceptions of society divided into two spheres: public and private. White men dominated the public sphere, and controlled the dependent private sphere, which included women, children, and African Americans. ${ }^{532}$ The continued political participation of blacks threatened political and economic stability. Freedmen, they maintained, should still be considered dependents; they were incapable of

\footnotetext{
${ }^{530}$ Benjamin R. Justesen, "'The Class of ' 83 ': Black Watershed in the North Carolina General Assembly," The North Carolina Historical Review 86, no. 3 (July 2009): 282-283.

${ }^{531}$ Ibid, 283-284.

${ }^{532}$ For discussions of gender and southern politics after the Civil War, see: Laura F. Edwards, Gendered Strife and Confusion: The Political Culture of Reconstruction (Urbana: University of Illinois Press, 1997); Glenda Elizabeth Gilmore, Gender and Jim Crow: Women and the Politics of White Supremacy in North Carolina, 1896-1920 (Chapel Hill: University of North Carolina Press, 1996); and Martha Hodes, "The Sexualization of Reconstruction Politics: White Women and Black Men in the South After the Civil War," Journal of the History of Sexuality 3, no. 3 (January 1993): 402-417.
} 
thinking independently, uneducated, and served as political pawns. ${ }^{533}$ Conservatives pledged to maintain the state's white republicanism, currently threatened by Republican dominance. The political equality proposed by the Republican Constitution of 1868, in the eyes of Conservatives, would lead to social equality, including miscegenation. ${ }^{534}$ By drawing the racial line as the political issue of the day, the party attracted many white voters by 1870 .

The presence of freed blacks empowered by citizenship alongside disenfranchised white former Confederates created social tensions. Race riots occurred throughout the Reconstruction South. More than thirty resulted in at least one death. ${ }^{535}$ Many riots happened in areas with a black majority, and over a third took place within two weeks of an election or on an election day. Often, these violent clashes began with an attempt by whites to prevent African Americans from politically organizing or voting. The white supremacist organization, the Ku Klux Klan (KKK), founded in Pulaski, Tennessee, in 1865 , played a significant role in racial violence and voter intimidation. ${ }^{536}$ The

\footnotetext{
${ }^{533}$ Zipf, "'The Whites Shall Rule the Land or Die'," 513.

${ }^{534}$ Ibid, 499-500; 514-516.

${ }^{535}$ Melinda Meek Hennessey, "Racial Violence During Reconstruction: The 1876 Riots in Charleston and Cainhoy,” The South Carolina Historical Magazine 86, no. 2 (April 1985): 100.

${ }^{536}$ Scholarly treatments of the Reconstruction era Ku Klux Klan include: Elaine Frantz Parsons, Ku-Klux: The Birth of the Klan During Reconstruction (Chapel Hill: University of North Carolina Press, 2015) and "Midnight Rangers: Costume and Performance in the Reconstruction-Era Ku Klux Klan," The Journal of American History 92, no. 3 (December 2005): 811-836; Otto H. Olson, "The Ku Klux Klan: A Study in Reconstruction Politics and Propaganda," The North Carolina Historical Review 39, no. 3 (July 1962): 340-362; Richard Zuczek, "The Federal Government's Attack on the Ku Klux Klan: A Reassessment," The South Carolina Historical Magazine 97, no. 1 (January 1996): 47-64; Wyn Craig Wade, The Fiery Cross: The Ku Klux Klan in America (New York: Simon and Schuster, 1987); Allen W. Trelease, White Terror: The Ku Klux Conspiracy and Southern Reconstruction (New York: Harper \& Row, 1971); Richard T. Schaefer, "The Ku Klux Klan: Continuity and Change," Phylon 32, no. 2 (2 ${ }^{\text {nd }}$ Quarter 1971): 143-157; David M. Chalmers, Hooded Americanism: The History of the Ku Klux Klan (Durham: Duke University
} 
Reconstruction Act of 1867 spurred an increase in Ku Klux Klan membership. ${ }^{537}$ By 1868, the organization had spread to nine Southern states. ${ }^{538}$ Led by Grand Wizard (and former Confederate General) Nathaniel Bedford Forrest, the KKK sought to reverse the changes brought about by Reconstruction, with significant emphasis on overturning black voting rights and defeating the Republican Party. During the election of 1868, the Ku Klux Klan attempted to prevent Republican and African Americans from voting in a variety of violent ways. Some of these methods included destruction of property, threats, and acts of violence. In Arkansas, white hooded men assassinated U.S. Congressman James M. Hinds. In South Carolina, the Klan murdered three members of the state legislature. The Ku Klux Klan also terrorized black communities, resulting in nearly two hundred deaths, and destroyed Republican newspapers in Louisiana. ${ }^{539}$

The Ku Klux Klan first appeared in North Carolina during the election of 1868. The tension between the interracial Republican alliance and Conservatives turned the Piedmont into a hotbed of KKK activity. In the Piedmont, a successful alliance of blacks and whites made the Republican Party politically viable and the Ku Klux Klan's sporadic acts of violence had little effect on the election. Republicans won a majority in the General Assembly and William Holden elected to the governorship. The Ku Klux Klan gained political strength in 1869 , as many white North Carolinians became frustrated

\footnotetext{
Press, 1965); and Stanley F. Horn, Invisible Empire: The Story of the Ku Klux Klan, 1866-1871 (Boston: Houghton Mifflin Co., 1939).

${ }^{537}$ Jim D. Brisson, “'Civil Government Was Crumbling Around Me': The Kirk-Holden War of 1870," The North Carolina Historical Review 88, no. 2 (April 2011): 128.

${ }^{538}$ Ibid, 126-128.

${ }^{539}$ Ibid.
} 
with the actions of the Republican administration, and their tactics grew more violent. A "reign of terror" commenced in the area resulting in at least fifteen murders during the summer. Convinced of the Republican threat to white supremacy, Klansmen committed hundreds of violent acts from 1869 to $1872 .^{540}$ The hooded organization argued that Republicans held responsibility for the outbreak of violence. The "acts and teachings of the Radical Party of the State" had created a state of anarchy by allowed African Americans political rights. The looming threat of social equality meant that white womanhood needed to be protected, and the Ku Klux Klan glorified itself as an organization upholding the law, punishing criminals, discouraging crime, and protecting property, white womanhood, and racial purity. ${ }^{541}$

The violent behavior of the North Carolina Ku Klux Klan drew the attention of its Republican Governor, Kirk Holden, who dedicated his administration to eliminating the Klan. ${ }^{542}$ After Klansmen murdered a Republican state senator the county courthouse in Yanceyville, Holden declared the action amounted to an insurrection. In 1870, the Governor ordered George W. Kirk to organize a militia force of several hundred men into the Piedmont to suppress the group of hooded vigilantes. During the "Kirk-Holden War," Kirk arrested more than one hundred men suspected of having ties to the Klan. Under orders from the governor, he held them for several weeks, ignoring writs of habeas corpus issued by North Carolinian judges. The militia occupation proved a political

\footnotetext{
${ }^{540}$ Olson, "The Ku Klux Klan: A Study in Reconstruction Politics and Propaganda," 341-342; and Brisson, "'Civil Government was Crumbling All Around Me'," 123.

${ }^{541}$ Ibid, 341-344.

${ }^{542}$ Brisson, "'Civil Government was Crumbling All Around Me'," 123-124.
} 
disaster for Holden. Without support in Washington, he was forced to release his prisoners. Democrats seized on the incident in the 1870 election, arguing Holden's actions were an illegal attack on his political enemies. ${ }^{543}$ Democrats took control over the North Carolina legislature in 1870 and successfully impeached Holden.

The Ku Klux Klan maintained a presence in the state until The Congressional Enforcement Acts of 1870 and 1871 granted the federal government power to prosecute crimes previously seen as within the jurisdiction of individual states, and instituted a variety of federal regulations on state affairs. The first Enforcement Act in 1870 banned the use of terror, force, or bribery to prevent a certain racial group from exercising their suffrage rights. It also allowed for the federal prosecution of KKK members, a power formerly possessed by the state, as well as the suspension of habeas corpus. The first two Enforcement Acts of 1871 permitted federal oversight of state and local elections at the request of a small number of citizens. The third Enforcement Act of 1871, known as the Ku Klux Klan Act, made any state official guilty of depriving individuals of their Constitutionally guaranteed rights liable for their actions in a federal court. It also authorized the President to send in militia forces to suppress Ku Klux Klan violence and to suspend habeas corpus, and banned anyone suspected of KKK associations from serving on juries for Klan related cases. ${ }^{544}$

The legislative debate over political equality persisted until 1876, increasing in intensity from 1872 to 1875 . Segregation formed the heart of this disagreement, influenced by a national argument over Senator Charles Sumner's attempts to pass a new

${ }^{543}$ Brisson, "Civil Government was Crumbling All Around Me'," 123-124.

${ }^{544}$ Escott, North Carolinians in the Era of the Civil War and Reconstruction, 225. 
civil rights bill to supplement to Civil Rights Act of $1866{ }^{545}$ Eventually passed in 1875 , the newest Civil Rights Act, guaranteed African Americans equal treatment in public accommodation, public transport, and to prohibit race based exclusion from jury service. The supplemental bill originally included a provision for integrated public schools, which, in turn, led white conservatives to demand a provision for segregated schools in the North Carolina Constitutional Convention of 1875. In 1876, this provision was included in the state's newly ratified constitution. By the election of 1876 , however, the topic of equality had fallen out of favor as the economy continued to rapidly industrialize. Northern and Southern opponents of the Republican administration called for a "clean" government, one free from special interests of race, labor, or business. This ideal gained popularity, speeding the formal end of Reconstruction in $1877 .^{546}$

Late-nineteenth and early-twentieth century popular and academic interpretations of Reconstruction's events and consequences varied. ${ }^{547}$ Immediately during and after

\footnotetext{
${ }^{545}$ Escott, North Carolinians in the Era of the Civil War and Reconstruction, 225.

${ }^{546}$ Richardson, West From Appomattox, 85-88.

${ }^{547}$ On reconciliation, race, and the collective memory of American Civil War history, see Patrick Gerster and Nicholas Cords, "The Northern Origins of Southern Mythology," The Journal of Southern History 43, no. 4 (November 1977): 567-582; Charles Reagan Wilson, Baptized in Blood: The Religion of the Lost Cause, 1865-1920 (Athens: University of Georgia Press, 1980); Nina Silber, The Romance of Reunion: Northerners and the South, 1865-1900 (Chapel Hill: University of North Carolina Press, 1993); John Pettegrew, "'The Soldier's Faith': Turn-of-the-Century Memory of the Civil War and the Emergence of Modern American Nationalism," Journal of Contemporary History 31, no. 1 (January 1996): 49-73; Pamela Brandwein, Reconstructing Reconstruction: The Supreme Court and the Production of Historical Truth (Durham: Duke University Press, 1999); David W. Blight, Race and Reunion: The Civil War in American Memory (Cambridge: Harvard University Press, 2001); Alice Fahs and Joan Waugh, eds., The Memory of the Civil War in American Culture (Chapel Hill: University of North Carolina, 2004); James C. Cobb, Away Down South: A History of Southern Identity (New York: Oxford University Press, 2005); Bruce Baker, What Reconstruction Meant: Historical Memory in the American South (Charlottesville: University of Virginia Press, 2007); Ben Railton, Contesting the Past, Reconstructing the Nation: American Literature and Culture in the Gilded Age, 1876-1893 (Tuscaloosa: University of Alabama Press, 2007); Thomas M. Allen A Republic in Time: Temporality and Social Imagination in Nineteenth-Century America (Chapel Hill: University of North Carolina Press, 2008); Elson Frank Bond, "Sentiment and Race in the Struggles for American Memory and Identity, 1879-1913," Ph.D. Dissertation, Fordham University, 2008;
} 
Reconstruction, writers portrayed the entire period in blatantly partisan terms.

Northerners cast the period as a moral Unionist issue, extolling the preservation of the nation, denouncing Southerners as traitors, advocating equal rights, and dismissing Johnson's administration as incompetent. Henry Wilson, for example, a former Radical Republican politician, published a three volume, undocumented work titled History of the Rise and Fall of the Slave Power in America from 1872-1877. In these works, Wilson criticized Democrats from both the North and South for failing to meets the needs of freedpeople, as well as white Southerners' belief in racial hierarchy. ${ }^{548}$ James G. Blaine, a founder of the Republican Party, previous member of Congress, and former secretary of state, published his 2 vol. Twenty Years of Congress: From Lincoln to Garfield, with a Review of the Events Which Led to the Political Revolution of 1860. Blaine was a moderate on Reconstruction, and sharply criticized slavery and disunion and underscored the unwillingness of white Southerners to accept the true freedom of African Americans and national sovereignty. ${ }^{549}$

Susan L. Mizruchi, The Rise of Multicultural America: Economy and Print Culture, 1865-1915 (Chapel Hill: University of North Carolina Press, 2008); Stuart W. Towns, Enduring Legacy: Rhetoric and Ritual of the Lost Cause (Tuscaloosa: University of Alabama Press, 2010); Victoria Bynum, The Long Shadow of the Civil War: Southern Dissent and Its Legacies (Chapel Hill: University of North Carolina Press, 2010);

Aaron Sheehan-Dean, "The Long Civil War: A Historiography of the Consequences of the Civil War," The Virginia Magazine of History and Biography 119, no. 2 (2011): 106-153; John David Smith and J. Vincent Lowery, eds., The Dunning School: Historians, Race, and the Meaning of Reconstruction (Lexington: University Press of Kentucky, 2013); Carolina E. Janney, Remembering the Civil War: Reunion and the Limits of Reconciliation (Chapel Hill: University of North Carolina Press, 2013); and K. Stephen Prince, Race and the Reconstruction of Southern Identity, 1865-1915 (Chapel Hill: University of North Carolina Press, 2014).

${ }^{548}$ Henry Wilson, History of the Rise and Fall of the Slave Power in America, 3 vols. (Boston: James R. Osgood, 1872-1877), 737-738.

549 James G. Blaine, Twenty Years of Congress: From Lincoln to Garfield, with a Review of Events Which Led to the Political Revolution of 1860, 2 vols. (Norwich, Connecticut: Henry Bill Publishing, 1884 and 1893). 
A partisan alternative to the Unionist narrative emerged first in 1866, with the work of Edward A. Pollard. His 1866 work, The Lost Cause: a New Southern History of the War of the Confederates: Comprising a Full and Authentic Account of the Rise and Progress of the Late Southern Confederacy—the Campaigns, Battles, Incidents, and Adventures of the Most Gigantic Struggle of the World's History, introduced the term "Lost Cause" in the academic vocabulary. Rather than focusing on slavery as the cause of the Civil War, Pollard's monograph represents an early example of the states' rights argument for pre-war Southern secession combined with Southern distinctiveness. To Pollard, the slavery question "was significant only of a contest for political power, and afforded nothing more than a convenient ground of dispute between two parties, who represented not two moral theories, but hostile sections and opposite civilizations." The Civil War, in this interpretation, was an issue of both states' rights to defend their way of life and Northern desires for power. Though Southerners lost the war, they need not submit to the domination of the North. Southern civilization, in Pollard's formulation, was vastly superior to it materialistic Northern counterpart. He urged Southerners to resist Northern-style economic development, which could lead to the end of Southern principles. Instead, Pollard called on Southerners to wage a "war of ideas" that would preserve essential elements of antebellum Southern culture, and solidify a collective Southern identity rooted in the memory of Confederates' valiant struggle. ${ }^{551}$

\footnotetext{
${ }^{550}$ Edward A. Pollard, The Lost Cause: a New Southern History of the War of the Confederates: Comprising a Full and Authentic Account of the Rise and Progress of the Late Southern Confederacy-the Campaigns, Battles, Incidents, and Adventures of the Most Gigantic Struggle of the World's History (New York: E.B. Treat, 1866), 46-51.

${ }^{551}$ Ibid, 749-759.
} 
Other works built on Pollard's support for states' rights in criticizing Radical

Reconstruction. James Shepard Pike, a Northern journalist, Hilary A. Herbert,

Democratic congressman, former Confederate officer, and secretary of the navy under

President Grover Cleveland, and historian James Ford Rhodes, all condemned

Reconstruction as an example of government corruption and the need to protect states'

rights. ${ }^{552}$ The many representations of the South in these works assisted in shaping

national perceptions of the region and its inhabitants. ${ }^{553}$ James Ford Rhodes represented

a new generation of professional American historians, like Dixon and Woodrow Wilson,

who belonged to the post-war generation. Most began writing in the 1890 s and did not

concern themselves with direct questions of war guilt. ${ }^{554}$ Rhodes' 1892 History of the

\footnotetext{
${ }^{552}$ See James Shepard Pike, The Prostrate State: South Carolina Under Negro Government (New York: D. Appleton, 1874); Hilary A. Herbert, ed., Why the Solid South? Or, Reconstruction and Its Results (Baltimore: R.H. Woodward, 1890), xv-xvii; and James Ford Rhodes, History of the United States from the Compromise of 1850 to the Final Restoration of Home Rule at the South in 1877, 9 vols. (New York: Macmillan, 1920).

${ }^{553}$ Further reading on the creation of Southern identity and national perceptions of the South may be found in: Daniel Taylor Buffington, "A South in the North: Emplacing the South in the American National Myth," National Identities 13, no. 3 (2011): 235-251; Karen L. Cox, Dreaming of Dixie: How the South was Created in American Popular Culture (Chapel Hill: University of North Carolina Press, 2011) and Dixie's Daughters: The United Daughters of the Confederacy and the Preservation of Confederate Culture (Gainesville: University Press of Florida, 2003); Trent A. Watts, One Homogenous People: Narratives of White Southern Identity, 1890-1920 (Knoxville: University of Tennessee Press, 2010); Laura F. Edwards, "Southern History as American History," The Journal of Southern History 75, no. 3 (August 2009): 533564; David R. Jansson, "The Haunting of the South: American Geopolitical Identity and the Burden of Southern History," Geopolitics 12 (2007): 400-425; Ted Tunnell, "Creating the Propaganda of History: Southern Editors and the Origins of Carpetbagger and Scalawag," Journal of Southern History 72, no. 4 (November 2006): 789-822; W. Fitzhugh Brundage, The Southern Past: A Clash of Race and Memory (Cambridge: Harvard University Press, 2005); James C. Cobb, Away Down South: A History of Southern Identity (New York: Oxford University Press, 2005); Tara McPherson, Reconstructing Dixie: Race, Gender, and Nostalgia in the Imagined South (Durham: Duke University Press, 2003); Richard Nelson Current, Those Terrible Carpetbaggers (New York: Oxford University Press, 1988) and Northernizing the South (Athens: University Press of Georgia, 1983); Daniel E. Sutherland, The Confederate Carpetbaggers (Baton Rouge: Louisiana State University Press, 1988); Lawrence N. Powell, New Masters: Northern Planters during the Civil War and Reconstruction (New York: Fordham University Press, 1980); and Dewey W. Grantham, The South and the Sectional Image: The Sectional Theme Since Reconstruction (New York: Harper \& Row, 1967).

${ }^{554}$ Prince, Stories of the South, 201; 357.
} 
United States from the Compromise of 1850 placed slavery squarely within the causes of the Civil War, but portrayed the institution as an inherited curse, removing blame from Confederate leaders. Rhodes also paralleled the cultural revival of the martial ideal and matched the collective memory of the Civil War by expressing sympathy and honor on both sides of the conflict.

Throughout the early-twentieth century, the nation waged "a literary war for the soul of the South." ${ }^{555}$ Competing visions of Southern history, and the South's place in the nation, emerged from the multitude of written works on the subject. In the realm of popular literature, sentimental reconciliationist literature saturated American culture by the mid-1880s and throughout the early 1900s, published in the most popular books and magazines such as McClure's, Harper's Weekly, and Cosmopolitan. Novels, memoirs, newspaper articles, and travel narratives also shaped national perceptions of the South throughout American history. Some white Southerners believed that the Northern authored works that dominated the industry, such as Harriet Beecher Stowe's Uncle Tom's Cabin, and Albion Tourgee's A Fool's Errand, perpetuated a falsely negative image of the region. Northerners, in this formulation, could never understand a region they did not originate in. Southern newspaper editor, Walter Hines Page encouraged Southerners to write their own story through literature, which could capture the region's true image more effectively than history. He believed that eliminating their "ignorance" of the South's virtues could overturn Northern criticisms of the American South. ${ }^{556}$

\footnotetext{
${ }^{555}$ Prince, Stories of the South, 209-210.

${ }^{556}$ Ibid, $149-151$.
} 
Through popular literature and historical literature, competing views of the Civil War and Reconstruction reached a nationwide market. Exemplified by William Archibald Dunning's 1907 Reconstruction, Political and Economic, 1865-1877, the "Dunning School" situated Reconstruction as the pivotal moment of sectional discord in U.S. history. ${ }^{557}$ Dunningites argued that radical Republican legislation devastated the Reconstruction South, sowing deeper seeds of sectional discord. By allowing African American freedmen power Radical Republicans had unleashed political chaos and economic on the postwar South. Dunning's paternalistic opinion of African Americans viewed them as a group in need of constant supervision, not a group worthy of voting rights and political power. Northern policies during Reconstruction prevented Southerners from re-establishing a social hierarchy capable of controlling the recently freed slaves. The eventual end of Reconstruction, and restoration of power to white Southerners, represented both a political victory and a moral redemption for the South itself. ${ }^{558}$ Americans favoring political equality painted their own portrait of racial conditions in the South, and the future of the region: Reconstruction was not a period of terror for Southern whites, but a span of suffering for African Americans at the hands of their former masters. The systematic abuse of blacks contributed to their status, these activists maintained, their place in society was not biologically determined. African Americans, in this argument, deserved the rights guaranteed to American citizens in the Constitution, including voting privileges.

\footnotetext{
${ }^{557}$ For recent scholarly analyses of Dunning and his legacy, refer to: John David Smith and J. Vincent Lowery, eds., The Dunning School: Historians, Race, and the Meaning of Reconstruction (Lexington, University of Kentucky Press, 2013).

${ }^{558}$ See William A. Dunning, Reconstruction, Political and Economic, 1865-1877 (New York: Harper \& Brothers, 1907).
} 
Dixon was one of many Southern authors responding to Page's request at the turn-of-the-century. His solution involved making the North understand the South through a retelling of North Carolina's Reconstruction events. He believed if he could make the rest of the country understand the atrocities suffered by honorable Anglo-Saxon citizens during Reconstruction, America could unite behind a mission to protect its whiteness, and thus its national power. The first trilogy, which included The Leopard's Spots: A Romance of the White Man's Burden, 1865-1900 (1902), The Clansman: An Historical Romance of the Ku Klux Klan (1905), and The Traitor: A Story of the Fall of the Invisible Empire (1907), attempted to explain Southern history and stimulate sectional understandings. The Reconstruction Trilogy was also intended to demonstrate incompatibility between the two races, and ultimately drum up support for colonization, one of Dixon's preferred long-term "solutions" to the "problem."

The Reconstruction Trilogy, as a whole, tells personal relationship stories against the backdrop of Reconstruction's historical events and their long-term effects. Dixon's first novel, The Leopard's Spots (1902), marked the initial book in the Reconstruction Trilogy. Focusing on the years from 1865 to 1900, The Leopard's Spots traces the events of Reconstruction and their impact on race relations in North Carolina. Book I, "Legree's Regime," focuses on the Reconstruction period, while Book II, "Love's Dream," and Book III, "Trial by Fire," center on the 1880s and 1890s. The novel, in short, follows the life of Charles Gaston and the events of his small North Carolina community. During Book I, Gaston, a child during Reconstruction, becomes a political champion of white supremacy after his experiences under federal rule. This section of the book portrays the rise and fall of the Reconstruction Ku Klux Klan, and white Southerners' subsequent 
seizure of political power in the KKK's wake. In Books II and III, Gaston's home state is plagued by political corruption, economic struggle, and racial violence, which he blamed on political equality and the corrupt Republican governments of Reconstruction. After a white mother and her teenage daughter commit suicide after being raped by an African American man, the white Southern men of North Carolina unite to instill white supremacy in the state government. The book concludes with a turn-of-the-century white political revolution at the national level, in which a new Democratic federal administration declares its intention to nullify the Fourteenth and Fifteenth Amendments.

While the first book "was the statement in historical outline of the conditions from the enfranchisement of the Negro to his disfranchisement," the second novel "develops the true story of the 'Ku Klux Conspiracy,' which overturned the Reconstruction regime. ${ }^{, 59}$ The chronological equivalent of Book I in its predecessor, The Clansman, the second installation of the trilogy, covers five years from 1865 to 1870 . This novel delineates events from the development and implementation of Reconstruction to the seizure of political power by the Ku Klux Klan. Rather than a single life, however, this tale follows two developing intersectional (between Northerners and a Southerners) romances over the course of five years. The story follows two families, the Stonemans and the Camerons, while simultaneously tracing the events of Reconstruction. The Clansman is divided into four parts. Book I, "The Assassination," covers the months spanning from the end of the war to Lincoln's death. It begins in Washington, D.C., before Lincoln's death in 1865, and introduces the main characters. Elsie Stoneman,

\footnotetext{
${ }^{559}$ Thomas Dixon, The Clansman: An Historical Romance of the Ku Klux Klan (New York: Doubleday, Page \& Company, 1905), "To the Reader."
} 
daughter of Republican legislator Austin Stoneman, meets Ben Cameron, a former Confederate sentenced to death, while volunteering at the hospital. ${ }^{560}$ Ben's family, sister Margaret and mother Mrs. Cameron, arrive to fight for Ben's freedom, asking Elsie for help. Elsie lobbies President Lincoln for Ben's pardon, and succeeds. Lincoln's death creates a power vacuum allowing Radical Republican Austin Stoneman to take control over the federal government. ${ }^{561}$

Book II, “The Revolution,” and Book III, “The Reign of Terror,” discuss the implementation and results of Stoneman's radical Reconstruction. His mulatto housekeeper, Lydia Brown, is portrayed as one of the main influences driving Stoneman's Reconstruction efforts. ${ }^{562}$ As plans for confiscation of property, disfranchisement of whites, and the enfranchisement and arming of African Americans are instituted, social and economic chaos ensued in the South. Racial tensions flared, driven by carpetbaggers and scalawags that fueled anti-white sentiment among the blacks. These sections are also where the two pairs of lovers, Elsie Stoneman and Ben Cameron, and their siblings Phil Stoneman and Margaret Cameron, realize their feelings and act upon them. Ben and Phil grow increasingly concerned with the political state of affairs throughout these two sections. Ben meets with General Forrest about his worries, and established a Ku Klux Klan in North Carolina. As interracial governments took control of the Carolinas, the violence worsened. Several white Southerners' barns were set aflame, and after several months the state capital of South Carolina had been rendered

\footnotetext{
${ }^{560}$ Dixon, The Clansman, 9-10.

${ }^{561}$ Ibid, $76,89$.

${ }^{562}$ Ibid, 91.
} 
inept and bankrupt. Tensions boiled over after a group of African American men rape two Southern women, Mrs. Lenoir and her daughter Marion, resulting in their suicide. ${ }^{563}$

The final part of the novel, "The Ku Klux Klan," centers on the emergence of the North Carolina KKK and its role in re-establishing white rule in the South. Here, Dixon makes it clear that the Ku Klux Klan, in his interpretation, formed and acted out of necessity to protect the race, the South, and the nation. The rape of the Lenoir woman stirred Ben's new Ku Klux Klan to action. The group captured the rapist, executed him, and then proceeded to disarm African American men and intimidate them into staying away from the polls. ${ }^{564}$ Their actions succeeded, and a majority-white, Democratic coalition emerged victorious in the election, saving the South, the race, and the nation from barbarism. ${ }^{565} \mathrm{He}$ tries to make it clear that the pre-1870 KKK rooted its existence in honorable intentions, disbanding after the 1870 election because its work was done. Instead, he argues that the Ku Klux Klan Acts of 1871 resulted from a rogue element that ignored this dissolution and carried out wanton acts of violence. The Ku Klux Klan, as organized by its original leaders, Dixon maintained, had reversed the course of radical Reconstruction.

The final novel of the trilogy, The Traitor: A Story of the Fall of the Invisible Empire (1907), focused on the years from 1870 to 1872 . The tale separates the "true" $\mathrm{Ku}$ Klux Klan from the "rogue" Ku Klux Klan, blaming the latter for the violent actions that spurred the Ku Klux Klan Acts in 1871. It "opens with the dissolution [of the KKK] by

\footnotetext{
${ }^{563}$ Dixon, The Clansman, 116-118; 260-266; 300-305.

${ }^{564}$ Ibid, 327-328.

${ }^{565}$ Ibid, 374.
} 
General Forrest and is set in the atmosphere of the fierce neighborhood feuds, which marked the Klan's downfall in the Piedmont region of the South." ${ }^{566}$ In the midst of these squabbles arose the "New Klan" or "rogue" Ku Klux Klan, as Dixon terms it. ${ }^{567}$ In three parts, Dixon tells the story of the New Ku Klux Klan's rapid rise and fall. Like the previous installations in the trilogy, The Traitor's plot is straightforward an simple, as Dixon's message lies in the narrative's rhetoric and major events. Book I, "The Crime," opens with John Graham, a chief of the original KKK, former Confederate soldier, lawyer, and politician, attempting to gain entrance to his former home. The family land had been seized and resold, illegally, during Reconstruction. The entire family, including Graham's father, younger brother, and servant, moved to rented rooms in another household. Graham's childhood home now belonged to Judge Butler, of the U.S. Circuit Court. He and Graham are enemies; Butler previously disbarred Graham. In addition to this personal attack and Butler's occupancy of the Graham family homestead, John Graham is convinced that a confrontation between Butler and his mother, Mrs. Graham, resulted in her death and his father, Major Graham's, mental breakdown. ${ }^{568}$

The story continues with John Graham confronting Butler by procuring access via a secret tunnel between the house and the family vault. ${ }^{569}$ Graham claimed to have proof of Butler's corrupt machinations and illegal arrangement to buy the former Confederate family's land, but the Judge refused to leave the house until "ordered by the Supreme

\footnotetext{
${ }^{566}$ Thomas Dixon, The Traitor: A Story of the Fall of the Invisible Empire (New York: Grosset \& Dunlap, 1907), "To the Reader."

${ }^{567}$ Dixon, The Traitor, "Leading Characters of the Story."

${ }^{568}$ Ibid, 3-6; 11-12.

${ }^{569}$ Ibid, 13.
} 
Court of the Unites States" or "carried out—feet foremost—-through that door." The Judge warned Graham that if he dared challenge Butler's authority he would "order a regiment of troops" into the town, send his "crazy old father to the county poorhouse," and Graham "to the gallows." $" 570$ With no solution to his grievances, Graham leaves determined to take revenge by suing Judge Butler for restoration of property. He does not get out the door, however, before having a love-at-first-sight experience with Butler's daughter, Stella. Stella, however, is engaged to Steve Hoyle, a Southern man of capital, politician, and promoter of Northern "money interests" in the region. ${ }^{571}$ This engagement is short-lived, as Stella tires of Steve's objections to her social endeavors and friendships. Since Graham failed to withdraw his suit against Butler, the Judge ordered a regiment of federal troops into the Piedmont. After an armed clash with the occupying soldiers, Graham decided it was time to disband the KKK in order to save its members from "persecution, exile, imprisonment, and death." Steve Hoyle, however, opposed Graham's dissolution plans, seeing an "opportunity to defeat his enemy and make himself not only the master of his Congressional District but of the state itself" by leading a "new order of patriots." The rogue Klan's behavior placed it at the top of Butler's carpetbaggerinfluenced political platform. His campaign championed "the destruction of the Klan by exile, imprisonment, and death." ${ }^{572}$ Stella, Butler's daughter, on the other hand, wanted to invite the Ku Klux Klan to a fancy dress ball at the Butler (formerly Graham home).

\footnotetext{
${ }^{570}$ Dixon, The Traitor, 21-23.

${ }^{571}$ Ibid, 34-35.

${ }^{572}$ Ibid, 52-55; 102.
} 
During the ball, men in Ku Klux Klan robes ordered Butler out of town and, when he refused, stabbed him in the heart before fleeing.

Book II, “A Woman's Revenge,” follows the events after Butler’s death. A wave of federal interest resulted in "the famous Conspiracy Act," which "made membership in the Ku Klux Klan a felony, and provided for the trial of its members of the charge of treason, conspiracy, and murder." ${ }^{573}$ Further, it authorized the President to intervene with military force. The county of Independence, North Carolina, was placed under military rule as federal detectives investigated Butler's death. After two months, no definite perpetrator emerged, though Graham was a prime suspect. Graham, though, suspects his father and brother were involved in the murder. Convinced he holds responsibility for the existence of the new Ku Klux Klan as organizer of the original, Graham decides to take the fall in order to protect his family and the Klansmen. ${ }^{574}$

Book III of this novel, "Prisoner and Traitor," follows Graham's trial and its surrounding circumstances. While in jail, held without bail and in solitary confinement, Graham is offered a bribe by the federal government. If Graham would reveal the secrets of the Ku Klux Klan, he would be rendering "the South and the Nation an enormous service" by helping "restore law and order." This action would be rewarded with a position as Assistant Prosecuting Attorney with an eventual Circuit Court Judgeship. ${ }^{575}$ Graham refuses. The same offer is made to Steve Hoyle, placed under house arrest following Ackerman's suspicions, and he agrees to cooperate. Hoyle's betrayal of his

\footnotetext{
${ }^{573}$ Dixon, The Traitor, 102.

${ }^{574}$ Ibid, 152-153.

${ }^{575}$ Ibid, 273-274.
} 
secrecy oaths led to the arrest of more than five hundred suspected Klansmen, and to a position as Assistant United States District Attorney. To defend the jailed men, Stella hired "two of the nation's greatest lawyers.",576 The legal battle was uphill, lasting eleven days. On the stand, the truth is revealed: Butler's political associate, Alexander Larkin committed the murder and framed the Ku Klux Klan. Graham and several of the men, though, are tried and convicted of conspiracy. ${ }^{577}$ The guilty, though, soon received hasty pardons, and the tale abruptly ends with recently freed Graham settling down with Stella.

At the broadest level, these novels reveal much about Dixon's personal life and experiences. He continued building on previous education, using research skills and methods acquired at Johns Hopkins to search and purchase sources concerning the Reconstruction and Civil War South, and read other historians' works to explore its topics. ${ }^{578}$ As "historical" novels, the Reconstruction Trilogy claimed authenticity and objectivity, with adjustments to "tone down the facts to make them credible in fiction." 579 He claimed to have poured through "more than four thousand volumes of historical and controversial material" in the eighteen months of research time preceding the publication of The Clansman. ${ }^{580}$ Like his graduate professors, Dixon believed history could be used

\footnotetext{
${ }^{576}$ Dixon, The Traitor, 288-289; 304-305.

${ }^{577}$ Ibid, 316-331.

${ }^{578}$ I.F. Marcosson, "Dixon as an Author: The Man and His Work Make an Interesting Study," The Washington Post, January 29, 1905; Thomas Dixon, Jr., "Mr. Dixon Explains: It Would Have Been 'Impossible' for Him to Acknowledge His Indebtedness to Dr. Craven in a Preface," New York Times, March 25, 1905.

579 Thomas Dixon, "Historical Note" in The Leopard's Spots: A Romance of the White Man's Burden, 1865-1900 (New York: Doubleday, Page, \& Company, 1903).

${ }^{580}$ Thomas Dixon, Jr., “Mr. Dixon Explains: It Would Have Been 'Impossible' for Him to Acknowledge His Indebtedness to Dr. Craven in a Preface," New York Times, March 25, 1905.
} 
to answer the problems of the present. His interpretation of history as driven by politics and the personal ambitions of powerful figures reflects Adams' influence, as well. All of Dixon's Reconstruction novel have a romantic element, common in the period, that intersects with the idea of national reconciliation: Northern characters fall in love with Southern characters after an understanding about their differences is reached. Important, too, are the novels' autobiographical elements. They are centered on Dixon's life and times, and reflect his growing disillusionment with urban life, his investment in history as a tool for political change in the present, and indicate his increasing concern with issues of race. The characters' dialogues also underscore Dixon's dedication to laying out his argument in (what he considered to be) an objective manner, the result of his graduate and legal training.

On a more nuanced level, the Reconstruction Trilogy demonstrates that, for Dixon, the developments of the first decade of the twentieth century represented a contemporary parallel to Reconstruction. The South, Civil War and Reconstruction history, and race relations appeared throughout each of its main issues. Like the postCivil War period, it offered the nation an opportunity to solidify into a singular, rather than sectional, identity. The country could seize the opportunity to eliminate its problems by embracing white supremacy. For Dixon, the key to this new nationalism and the new nation's global power was Anglo-Saxon whiteness: White Americans needed to unite in order for the country to fulfill its destiny as a global power, and it depended on the racial power of its citizens. "This republic is great today," he maintained, "because of the race of pioneer white freemen who settled this continent. On the preservation of the purity of 
this racial stock depends our future. ${ }^{581}$ These years also offered Americans a chance to further refine the relationship between race and society through discussions of citizenship and voting rights. African American political equality, in his formulation, posed serious threats to the nation by pitting Northerner against Southerner in the political system. Furthermore, Dixon believed political equality would lead to widespread miscegenation, weakening the country at its Anglo-Saxon roots. African American activism signaled, for him, potential danger in terms of the nation's future trajectory. Also similar to Reconstruction, the first years of the 1900s witnessed a new wave of Northerners headed South in an attempt at molding the region into its image. Like the carpetbaggers of the 1860 s and 1870s, progressive reformers threatened to ruin this national opportunity for reconciliation and the establishment of an Anglo-Saxon based political system through efforts at educating lower races. This period, in his mindset, could solve the nation's problems if the nation could unite behind its whiteness and forget sectionalism.

Dixon presented the Reconstruction Trilogy as "the most important moral deed" of his life. ${ }^{582}$ "I am no sectional fanatic," he proclaimed, "but a citizen of New York... This is my country - the whole of it... I love the people of the North, and I have promised that if God gives me strength they shall know mine own people of the South, and love them, too! Is this a crime?" ${ }^{, 583}$ He insisted the Trilogy's message served the best interests of the country, showing "that this Nation is now beginning to face an insoluble

\footnotetext{
581 “'The Clansman' At Show," Thomas Dixon, in Speech to Audience, Outlines his Mission," The Sun (Baltimore), April 30, 1907.

582 “Thomas Dixon,” An Author's Answer to His Critics, New York Times, August 9, 1902.

583 Thomas Dixon, Jr., "'The Clansman,' Its Authors, Thomas Dixon, Jr., Replies with Spirit and Good Humor to Some of His Critics," New York Times, February 25, 1905.
} 
problem." 584 The Race Question was "not merely an historical one," in Dixon's point of view, but "woven with the most vital and hopeless problems of American life... Its roots strike deep into our history, spread wide into our everyday life, and grip with power of fate the souls of generations unborn." situated geographically that they control enough votes to elect the President with the aid of but two Northern states," in Dixon's mind, was the practical reason that the rest of the nation needed to understand the region's history. ${ }^{586}$ "Can there be harmony until we understand each other?" he asked. ${ }^{587}$

In The Leopard's Spots, Dixon laid out the seminal themes and stylistic elements of the Reconstruction Trilogy as a whole. It set a trend for Dixon's themed novels, using a blend of history and fiction to demonstrate solutions to the problems of the present. $\mathrm{He}$ used the events of this period of interracial political participation, culled from historical resources as well as personal experience, to argue against equality for African Americans and for Southerners to be accepted and understood by the nation at large. The two were interlinked. The nation, Dixon maintained, needed to "look this [the negro] question squarely in the face," and realize that political equality for the races threatened "to blot out Anglo-Saxon society and substitute African barbarism. ${ }^{, 588}$ From the outset, Dixon

\footnotetext{
584 “Thomas Dixon,” An Author's Answer to His Critics, New York Times, August 9, 1902.

${ }^{585}$ Thomas Dixon, Jr., "The Story of the Ku Klux Klan: Some of Its Leaders, Living and Dead,” The Metropolitan Magazine 22, no. 6 (September 1905): 657.

586 “Thomas Dixon,” An Author's Answer to His Critics, New York Times, August 9, 1902.

${ }^{587}$ Thomas Dixon, Jr., “'The Clansman,' Its Authors, Thomas Dixon, Jr., Replies with Spirit and Good Humor to Some of His Critics," New York Times, February 25, 1905.

${ }^{588}$ Dixon, The Leopard's Spots, 96-97.
} 
makes the South and Southern characters a formative part of the nation. In The Leopard's Spots, North Carolina represents "the typical commonwealth of American freedmen," and is "broadly typical of the whole South... and therefore of the dominant American." 589 He argued that the novel gave "voice to the deepest soul convictions of these eighteen millions of our people" regarding the "insoluble problem" facing the nation, and represented an "honest effort" to encourage Northern understanding of the Southern experience after hearing "only one side for forty years.",590

The Leopard's Spots also demonstrates Dixon's participation in the larger cultural debate over the meaning of the ballot and its relationship to citizenship and racial equality. History stood first and foremost in his formulation. In each section, Dixon makes an argument against racial equality and for an Anglo-Saxon nation, based in his interpretation of historical trends in the period. The Progressive era debate over the rights guaranteed by the Constitution paralleled, to Dixon, Reconstruction arguments over the same topic: the very shape of the nation's future society depended on the outcome of this struggle between pro and anti-equality Americans. "Nationality," Dixon argued, "demands solidarity. And you can never get solidarity in a nation of equal rights out of two hostile races that do not intermarry." ${ }^{, 591}$ In the early-twentieth century, Americans possessed an opportunity to settle the suffrage issue forever and remedy the ills leftover from the 1860s and 1870s. Establishing the proper Anglo-Saxon constituency formed the basis of his contribution to national conversations. To Dixon,

\footnotetext{
${ }^{589}$ Thomas Dixon, “An Author’s Answer to His Critics,” New York Times, August 9, 1902.

${ }^{590}$ Ibid.

${ }^{591}$ Dixon, The Leopard's Spots, 335-336.
} 
voting rights were a powerful privilege, not a guaranteed perk of citizenship, to be exercised only by educated, patriotic white men. "The ballot is force," according to the author, backed by "the red blood of the man that votes." ${ }^{, 592}$ Since Dixon equated political equality with social equality, he believed "the beginning of Negro equality as a vital fact is the beginning of the end of this nation's life." By stripping the nation of its whiteness, and thus its rational democratic power, racial equality posed a serious threat to the country's global success. "The future of the world" depended on the "future of this Republic," he maintained in The Leopard's Spots, and "this Republic can have no future if racial lines are broken and its proud citizenship sinks to the level of a mongrel breed of Mulattoes." Dixon rejected the "shallow cosmopolitanism" typical of "the dishwater of modern citizenship." An ethnic Anglo-Saxon Americanism lived in "the true citizen of the world," and "his country is part of God's world. ${ }^{, 593}$ Only a white-ruled nation could possibly triumph on the modern, global stage.

The characters represent a combination of Dixon's stereotypical views, regional, racial, and national, along with historical information. Some characters are actual historical figures, such as and Abraham Lincoln, worked into Dixon's vision of events. Others, such as Austin Stoneman, are based on historical figures. In Stoneman's case, he is based on Thaddeus Stevens. Some characters have obviously autobiographical elements, such as Reverend Durham "the preacher who threw his life away," a "man of culture" that "graduated at the head of his class at Wake Forest," and "was a profound

\footnotetext{
${ }^{592}$ Dixon, The Leopard's Spots, 162-163.

${ }^{593}$ Ibid, 339-340; 200; and 444-445.
} 
student of men and books... more of a poet than theologian." ${ }^{594}$ The main characters, however, are a combination of fact and fiction, and most accurately underscore Dixon's views about different groups. These stereotypes are more complicated than NorthernSouthern and black-white categorizations. They are additionally divided along lines of gender, class, and ideology. There are different kinds of "whiteness" and "blackness," so to speak. The characters are largely symbolic, and their actions and conversations reveal the intricacies of Dixon's ideology regarding race, the South, and the nation.

Among Southerners, Dixon differentiates between men and women, whites and blacks, loyal men and disloyal men. Honorable white Southerners, such as Charles Gaston, General Daniel Worth, and Tom Camp, are portrayed as manly white supremacists, dedicated to national honor and protecting America's racial purity. Charles Gaston, the central character, symbolizes the young, new generation of Southern men coming to political power at the turn-of-the-century. He is not wealthy, due to the ravages of the war and Reconstruction, but comes from good Anglo-Saxon, former Confederate stock. He has, however, the nation's interest at heart in his efforts to solve racial problems. Tom Camp, the typical poor white Southerner, represents the long legacy of virulent anti-black racism among his class. ${ }^{595}$ Not that these characters had no factual elements, the political side of Charles Gaston, for instance, was based on the Governor of North Carolina, Aycock, and Tom Camp reflected Dixon's Confederate veteran cousin who told him stories of the war. ${ }^{596}$ Southern white womanhood, the basis

\footnotetext{
594 Dixon, The Leopard's Spots, 7-8.

595 Ibid, 28-29.

596 “Passing Throng,” The Atlanta Constitution, September 24, 1902.
} 
of Anglo-Saxon power and typified by innocence, virtue, and strength, is represented in the characters of Flora, Sallie, Annie, and Mrs. Durham. Simon Legree and Allen McLeod, on the other hand, represent the treacherous scalawag white Southerner, a former slave driver now stirring race tensions and cooperating with Northerners for the sake of his own profit. ${ }^{57}$ Black Southerners adhere to a good-bad dichotomy, portrayed either as loyal former slaves, such as the character of Nelse, or as dangerous, savage threats to civilization, like Dick.

Reflecting Dixon's investment in white supremacist thought, most African American characters represent the many forms of danger social equality poses to the nation. Blacks in The Leopard's Spots are of two types: "good" African Americans that accept their place in the hierarchy and "bad" African Americans who deviate from it by violating the social hierarchy or participating in politics. These two groups sometimes clash and overlap, and often-white political demagogues play a role in determining the actions of "bad" blacks. African American Southerner Nelse, the Gaston family's former slave, symbolizes the loyal, positive version of blackness in Dixon's work, happy in his inferior position and loyal to his former master. ${ }^{598} \mathrm{He}$ stands in opposition to the lawless, negative portrait of blackness found in the African American mobs burning barns, challenging white authority, and approaching white women. African American political leaders, such as Tim Shelby, and the influences of carpetbaggers and scalawags, encouraged these mobs. Characters like Dick, Charles Gaston's childhood friend who is

\footnotetext{
${ }^{597}$ Dixon, The Leopard's Spots, 87.

${ }^{598}$ Ibid, 7, 42-43.
} 
lynched for the rape of Flora, demonstrate the intimacy of the white-black relationship after the Civil War as well as the threat of black savagery. On the other side of the Mason-Dixon line, the author created character George Harris, a well-educated freeman from the North that represents the hope of Yankee reformers for the black race, as well as the perils of educating African American men. Any African Americans that challenge white supremacy, in Dixon's formulation, pose a danger to national life. The actions of these "bad" African American characters, rape, mob violence, racial intimidation, and demands for social equality, supplement Dixon's argument for a nation based on masculine white supremacy.

Dixon's treatment of Northerners reflects the mission of the book to reunite the sections. He lays the blame for Reconstruction's events on individual politicians, carpetbaggers, and a partisan system, rather than on the Union. Northern white characters are generally represented as carpetbaggers, but "Northerners" themselves receive significant respect. One carpetbagger example is Susan Walker, a reformer from Boston "whose liberality had built the new negro schoolhouse and whose life and fortune was devoted to the education and elevation of the Negro race." novel are combined with that of the Northerners running the Freedman's Bureau and the Union League to empower Southern blacks and stir race hatreds in order restrict the power of Southern whites. "Northerners" as a whole, however, were not offensive. "The genuine Yankee soldier settler" in the South after the Civil War "constituted the only conscience and brains visible in public life during the reign of terror which the

\footnotetext{
${ }^{599}$ Dixon, The Leopard's Spots, 44-46.
} 
Reconstruction regime inaugurated." Even "the abolitionists of the North... rose in solemn protest" against the conditions of radical Reconstruction, only to be drowned out by "the roar of multitudes maddened by demagogues who were preparing for a political campaign." ${ }^{600}$ Reconstruction itself is portrayed as product of "Charles Sumner, a crack brained theorist; Thaddeus Stevens, a club footed misanthrope; and B.F. Butler, a triumvirate of physical and mental deformity." ${ }^{601}$ Northerners remain largely unaware of its dark underbelly, they "do not dream of the awful conditions of the South; They are being fooled by the politicians..,

Book I, “Legree's Regime,” focuses on Reconstruction years, and provides the roots for Dixon's argument that the era had long-lasting consequences. This portion of The Leopard's Spots lays down foundational elements for the rest of the Trilogy's books. It aims to demonstrate the atrocities of Reconstruction in the South, their origins, and use them as a warning sign for Dixon's present. Book I also attempts to mend the sections by making intelligent Southerners and Northerners sympathetic to their fellow white Americans and conscious of the Anglo-Saxon heritage uniting them. Additionally, it roots Southern nationalism directly to the end of the Civil War, portraying the region as consistently American and patriotic. Dixon places Reconstruction at the heart of national race relations, arguing that the period's events polarized the races and the regions. His discussion of the era also attempts to undermine the political legitimacy of African

\footnotetext{
${ }^{600}$ Dixon, The Leopard's Spots, 85; 101-102.

${ }^{601}$ Ibid, 96-97.

${ }^{602}$ Ibid, 136-137.
} 
American voting rights by discrediting Reconstruction itself, justifying his anti-black ideology with the events of history.

Radical Reconstruction, in his formulation, shattered the Union and set the course for later decades' racial struggles. Throughout the first part of the novel, he attempts to undermine its legitimacy while demonstrating the dangers of African American equality. One method he employs to communicate this point is framing the postwar South as a patriotic, nationally minded place, and the Civil War itself as inevitable for the preservation of the Union. He portrayed national figures like Lincoln and Grant as sympathetic to the South's fight, granting legitimacy to the idea of the South as a patriotic location through revered Northern figures. ${ }^{603}$ Through the letters of a Confederate veteran, Dixon portrays Southern men as dedicated to the nation, but forced to defend the Constitution and their home, not fighting in defense of slavery. He asserted that after the war ended, "there was not the slightest effort to continue the lawless habits of four years of strife," and Southerners "were glad to be done with the war." Dixon argued, were far more concerned with rebuilding and progressing, as visible in the character of Tom Camp, who insists “we've got one country now and it's going to be a great one." ${ }^{605}$ They were also pleased slavery had ended, viewing it as an inherited system of burden, and sought to rebuild their society. The former Confederacy had not purposely restricted African Americans any more than the rest of the postwar nation, in his opinion. Southerners instituted race-based social restrictions "simply copied from

\footnotetext{
${ }^{603}$ Dixon, The Leopard's Spots, 23; 35.

${ }^{604}$ Ibid, 13-14; 34.

${ }^{605}$ Ibid, 79.
} 
code of the Northern states where free labor was the basis of society."606 The South was well on its way to postwar progress, and Radical Reconstruction "destroyed this scene of peaceful rehabilitation," shattering the possible peaceful postwar reunion. ${ }^{607}$

To Dixon, radical Reconstruction and racial equality proved mistakes from the outset. In The Leopard's Spots, its very conception was illegitimate, the product of personal vengeance, opportunity, and partisan politics. The Civil War, he insists, was not initiated for the sake of African American equality, but for the preservation of the Union. Political equality emerged as an accidental byproduct of the war's circumstances. The death of President Lincoln, who Dixon argued desired colonization, created a power vacuum and "a group of radical politicians, hitherto suppressed, saw their supreme opportunity to obtain control of the nation" and "fasten their schemes of proscription, confiscation, and revenge upon the South."608 The vengeful attitude of Thaddeus Stevens, Dixon's main architect of radical Reconstruction, drove these efforts. Partisan politics furthered his plot. Stevens planned to "give the nigger the ballot and take it from enough white men to give the niggers a majority," and "pass his bill to confiscate the property of the rebels and give it to loyal men and the niggers, and run the rebels out." Dixon emphasized the socio-economic devastation of North Carolina, using its suffering to highlight Reconstruction as an attack on a helpless people. In the South, "every woman," he detailed, "is a widow," "four million negroes had suddenly been freed, and

\footnotetext{
${ }^{606}$ Dixon, The Leopard's Spots, 66-67; 96-97.

${ }^{607}$ Ibid, $84-85$.

${ }^{608}$ Ibid, 67-78; 84-85.

${ }^{609}$ Ibid, 88-89.
} 
the foundations of economic order destroyed... the flower of its manhood buried in nameless trenches, or... flung upon the charity of poverty." ${ }^{\prime 610}$

The radical element of the government took advantage of the South's inability to fight back, and, in Dixon's narrative, worsened already bleak circumstances. It "destroyed the Union a second time, paralyzed every industry in the South, and transformed ten peaceful states into roaring hells of anarchy." ${ }^{611}$ Dixon dedicates large portions of this section to describing the social, economic, and political conditions of radical Reconstruction, focusing on how social equality and political equality overlapped and impacted whites. Meddling carpetbaggers and treacherous scalawags overtook the North Carolina landscape, and the Freedmen's Bureau and Union League assisted them in spreading Stevens' message. Dixon accused the pro-equality organizations of "dealing out arms and ammunition to them [African Americans], and what is worse, inflaming the worst passions against their former masters, teaching them insolence, and training them for crime." ${ }^{.612}$ Resulting from the efforts of Northern reformers and radicals, "the Negroes laid down their ploughs" and "crimes of violence increased daily." ${ }^{.613}$ White Southerners were faced with daily humiliations as blacks refused to adhere to the peaceful prewar social structures, ruining the economy ${ }^{614}$ Political equality, as interpreted by Dixon's interracial North Carolinian government, meant social equality to

\footnotetext{
${ }^{610}$ Dixon, The Leopard's Spots, 26-27; 34-35.

${ }^{611}$ Ibid, 84-85.

${ }^{612}$ Ibid, 32.

${ }^{613}$ Ibid, 91.

${ }^{614}$ Ibid, 41-42; 101; 202-203.
} 
the point of forced intermarriage and automatic divorce for former Confederate marriages. ${ }^{615}$ The actions of these few radicals, enabled by the partisan system, had endangered the entire nation by threatening its racial purity and political power.

Crucial to Dixon's tale is the assertion that Southern resistance to Reconstruction policies grew out of necessity and Anglo-Saxon patriotism. The conditions of radical Reconstruction left the nation with two choices: an Anglo-Saxon America or a Mulatto one. $^{616}$ By potentially granting racial intermarriage, the Reconstruction regime posed serious problems for the nation's Anglo-Saxon future, and the reunion of North and South. Dixon demonstrates the reality of these threats by delineating the humiliation and suffering of white Southern men and women at the hands of politically empowered African Americans. In addition to burning barns, rigging elections, and destroying the economy, black men in North Carolina disrespected and raped young white women. ${ }^{617}$ The radical Republicans' stance on social equality and miscegenation, in Dixon's mind, perpetuated these sexual offenses in legislation. Dixon designed these scenes as proof positive of black barbarity and sexual deviancy. If not stopped, the new regime would destroy the South and the Anglo-Saxon nation. ${ }^{618}$ The Ku Klux Klan rose against the Reconstruction regime in defense of their race, and to protect the white womanhood, which the entire nation depended on for its democratic power. The threats of the Reconstruction years drove Southerners into race-based politics, in Dixon's view.

\footnotetext{
${ }^{615}$ Dixon, The Leopard's Spots, 114; 147.

${ }^{616}$ Ibid, 98.

${ }^{617}$ Ibid, 125-129.

${ }^{618}$ Ibid, 115; 96-97.
} 
The Ku Klux Klan emerged in Dixon's narrative as a successful last-ditch effort to save Anglo-Saxon civilization. An important part of The Leopard's Spots is Dixon's belief that the Ku Klux Klan formed under extreme stress, and out of necessity. It represented "the old answer of organized manhood to organized crime" with the goal of bringing "order out of chaos," redeeming "the commonwealth from infamy," and reestablishing "civilization" in the state ${ }^{619}$ In one week, it restored civilization and succeeded in a political takeover of the region. This Ku Klux Klan, however, is complicated. Dixon demonstrates in this portion of the book a multidimensional conception of the Ku Klux Klan. Its "true" leader, Major Stuart Dameron, recognizes the organization's potential power for destruction and disbands it after the successful Democratic electoral overthrow. Dameron and the older members of the Klan believe its mission is complete, but the younger element in the brotherhood refused to accept this and reorganized with new leadership. ${ }^{620}$ This new, rogue Ku Klux Klan was to blame for the wanton acts of lawlessness that provoked Federal occupation of North Carolina. The original Klan, in his formulation, served the nation as well as the South in restoring white supremacy.

For Dixon, radical Reconstruction's long-lasting lasting effects proved his point. During the years from 1867 to 1870 , "a gulf as deep as hell and as high as heaven" opened between the races. ${ }^{621}$ Books II and III, "Love's Dream" and "The Trial by Fire," demonstrate some of these results, and trace interracial political efforts in North Carolina.

\footnotetext{
${ }^{619}$ Dixon, The Leopard's Spots, 151-152.

${ }^{620}$ Ibid, 169-171.

${ }^{621}$ Ibid, 101.
} 
Books II and III pick up eighteen years after the start of radical Reconstruction, and the distance between the races "had never been bridged." Instead, "it had crystallized into the solid rock that lies at the basis of society," and "could no more be undone now than you could roll the universe back on its course." This separation of black and white received further animus from the new generation of white men that "only knew the Negro as an enemy of his people in politics and society." Dixon believed "the effort was being made to build a nation inside a nation of two antagonistic races." ${ }^{.622}$ These two parts of The Leopard's Spots serve to bolster Dixon's argument that the racial elements set forth during Reconstruction continued shaping the nation. African American males' overt sexuality still posed danger to white women, provoking lynching as the late-nineteenth century equivalent of Klan justice. ${ }^{623}$ Southerners continued to maintain whiteness at the top of their political agendas, while African Americans persisted in the fight for their political representation and supposedly threatening white womanhood with potential rape, marriage, and harassment. By this time, Charles Gaston has reached adulthood, and entered North Carolina's political scene. He championed white supremacy and black disfranchisement.

Books II and III focus on Dixon's argument, using Gaston as a mouthpiece, against African American education and political equality. He links the racial tensions of the late-nineteenth century to interracial politics and black education, demonstrating the perilous place of Anglo-Saxonism in the future nation. Problems between white and black Americans still plagued the nation. Continued African American political

\footnotetext{
${ }^{622}$ Dixon, The Leopard's Spots, 202-203.

${ }^{623}$ Ibid, 362-363.
} 
participation, in his opinion, prevented cross-party cooperation. Southern Democrats, like Charles Gaston, voted strictly on racial lines, maintaining party loyalties even when "in accord with the modern Republican utterances at almost every issue." ${ }^{624}$ This continued political partisanship reinforced sectional and color lines. The interracial Farmer's Alliance, Populists, and their Republican supporters proved formidable political foes, reinstating the social conditions of Reconstruction in the 1880s and 1890s. This caused the outbreak of racial violence in those same decades. ${ }^{625}$ Black education, in Dixon's mind, proved devastating for multiple reasons. Education did not make life better for African Americans, but lifted them "out of their only possible sphere of their menial service, and denied any career." This was "simply inhuman," the equivalent of leading them to "certain slaughter of soul and body" by increasing "the power of the human brain to think and suffer." 626 "If you train the Negroes to be scientific farmers," he maintained, "they will become a race of aristocrats and when five generations removed from the memory of slavery a war of the races will be inevitable, unless the Anglo-Saxon grant this trained and wealth African equal social rights." ${ }^{.627}$ This, however, would equate to suicide for the Anglo-Saxon race and the power source of the nation.

Dixon concludes the book with a sweeping story of Anglo-Saxon American success, designed to link the novel with the turn-of-the-century context. He argues that the Spanish-American War united the nation, enabling white Americans to unite "at last

\footnotetext{
${ }^{624}$ Dixon, The Leopard's Spots, 200.

${ }^{625}$ Ibid, 385.

${ }^{626}$ Ibid, 265.

${ }^{627}$ Ibid, 338.
} 
and invincible. ${ }^{.628}$ Almost every problem of national life had been improved by the war save one- - "the irrepressible conflict between the African and the Anglo-Saxon in the development of our civilization.” African Americans could no longer depend on Northern sympathies, and "the glare of war only made the blackness of this [the race] question more apparent.." ${ }^{, 29}$ The tale comes to a close with a white supremacist government coming to power, successfully eliminating the Fourteenth and Fifteenth amendments in a "calm demonstration in open daylight of omnipotent racial power." ${ }^{, 630}$ United in AngloSaxon nationalism, America could now enter upon its "world mission" to conquer the globe and "establish and maintain for weaker races, as a trust for civilization, the principles of civil and religious liberty and the forms of constitutional government." ${ }^{\text {}}$

Like the first novel, The Clansman does more than lay out a narrative. It reflects Dixon's stance in the continued debates over the responsibilities of government to its subjects, the limits of federal power, corruption, and citizenship. The Clansman strengthens and clarifies Dixon's argument from The Leopard's Spots, and resembles the first novel in several ways. Like the first book, most of the characters serve as symbols and mouthpieces for Dixon's argument against African American equality, and the romantic narrative becomes a sideshow attraction in the larger story of racial, regional, and national survival. The Cameron family, which includes father Dr. Richard Cameron, Mrs. Cameron, daughter Margaret, and son Ben, represent typical Southerners. The

\footnotetext{
${ }^{628}$ Dixon, The Leopard's Spots, 412-413.

${ }^{629}$ Ibid.

${ }^{630}$ Ibid, 450.

${ }^{631}$ Ibid, 442.
} 
Stonemans, comprised of patriarch Austin (meant to portray Thaddeus Stevens), "radical leader of Congress," and his two children, Phil and Elsie, stand for Northern, Yankee thought and the personification Reconstruction politics. ${ }^{632}$ Austin Stoneman acts as Reconstruction's vindictive architect, and his children serve as symbols of generational sectional reunion. Their romantic involvement with the Cameron children, Ben and Margaret, represents national reconciliation among the new generation of Americans. Another similarity may be found in the way the second book's characters symbolize different elements of the cultural argument surrounding the race problem. They also demonstrate how Dixon perceived the nuances of nation, race, and region in individuals' lives. Each of the main characters serves additional symbolic functions to that of reunion, designed to reinforce Dixon's stance. Dr. Cameron and Stoneman represent the generation of Americans past, while their children become the hope for the future. Ben, as the "Grand Dragon of the Ku Klux Klan" serves as the brave, heroic, but wise former Confederate, forced to act in favor of his race. ${ }^{633}$ His sister, Margaret, and Mrs. Cameron, as well as white female characters Marion Lenoir and Mrs. Lenoir, her mother, symbolize traditional Anglo-Saxon, Southern, white womanhood, "sensitive souls" that harbored the strength of the race. ${ }^{634}$ The Lenoir women literally died for the sake of racial honor. Elsie Stoneman stands for Northern womanhood, a reflection of the "new" woman emerging at the turn-of-the-century. She denies "heaven born male kingship" and dreams "of a life that shall be larger than the four walls of a home" with a

\footnotetext{
${ }^{632}$ Dixon, The Clansman, "Leading Characters of the Story."

${ }^{633}$ Ibid.

${ }^{634}$ Ibid, 26.
} 
partner to inspire her development. ${ }^{635}$ This stands in opposition to both the Southern women and Ben's definition of manhood as "one that leads, charms, dominates, and yet eludes. ${ }^{\circ 636}$ Their differences are bridged, though, through love and understanding. Phil Stoneman, meanwhile, represents the young Northerner converted to Southern sympathies, and willing to fight for the future of his nation against the threats posed by African American equality. His love for the South is also expressed in his marriage to Margaret.

The villains in The Clansman parallel those in The Leopard's Spots, mainly powerful, vindictive men, partisan politics, and African American political equality, and miscegenation. The presence of African Americans is Dixon's root cause of all these problems. Historical characters like "carpetbagger" Colonel Howle, Charles Sumner, and Benjamin Butler underscore the threat of partisanship and sectional vengeance, but are not the cause of the problem. ${ }^{637}$ Dixon continues linking the origins of these problems to the presence of African Americans in the nation, and employs virulent anti-black language and caricature to reinforce his belief in racial separation. The Clansman heavily emphasizes miscegenation and political equality as dangers to the nation, using African American characters to demonstrate his point. Not only did blacks, as a looming group entity, refuse to respect their white neighbors, they terrorize and destroy the economy, rape white women, and perpetuate partisan political corruption. Characters such as black male Gus, the rapist, demonstrate the supposed animal-like sexual nature of African

\footnotetext{
${ }^{635}$ Dixon, The Clansman, 127-129.

${ }^{636}$ Ibid.

${ }^{637}$ Dixon, The Clansman, "Leading Characters of the Story."
} 
American men. ${ }^{638}$ This inevitably “proves” Dixon's argument that miscegenation, enabled by political equality, endangered the nation.

The second novel also revealed Dixon's beliefs regarding mixed-race peoples and their place in the nation; he believed they could easily sway advocates and control the government, if given the opportunity. This is best demonstrated in the characters of Silas Lynch, powerful mixed-race orator, and Lydia Brown, mulatto housekeeper. Both maintain close relationships to Congressman Stoneman. Lynch, an "orator of great power," "who had evidently inherited the full characteristics of the Aryan race, while his dark yellowish eyes... glowed with the brightness of the African jungle," cooperated with carpetbaggers to institute black domination. His public speaking skills threatened to ignite a race war in the Reconstruction South. Lydia "held the keys" to Stoneman's house as "first lady of the land," endangering the nation as its behind-the-scenes influence. ${ }^{639}$ This "tawny leopardess" influenced Stoneman to institute Reconstruction, using her inherent sexuality and cunning that resulted from her mixed-race heritage. ${ }^{640}$ The book does, however, still perpetuate a "good" versus "bad" black dichotomy. Some black characters, such as former slave Jake, represent the "good" African American, aware of his place in the racial hierarchy. For Dixon, the only way to solve these problems is racial separation.

Just as in The Leopard's Spots, in The Clansman, Dixon uses the events of Reconstruction to reinforce his argument against socio-political equality for African

\footnotetext{
${ }^{638}$ Dixon, The Clansman, 303-305.

${ }^{639}$ Ibid, 91.

${ }^{640}$ Ibid, 162-163.
} 
Americans. In addition to the individual enemies to white America's future, such as Lydia, Stoneman, and Gus, nameless, conceptual villains emerge in the wake of Reconstruction's attempts at political equality. In general, black voters and political equality drive of all the novel's problems, and African Americans proved their inability to uphold the honor and responsibilities of full citizenship. In Dixon's formulation, equal voting rights amounted to equal social rights, threatening the nation's whiteness with miscegenation. ${ }^{641}$ African American voters also endangered the entire system by enabling corrupt politicians via their naiveté, reigning down revenge upon white Southerners, and ruining the inner workings of the government. ${ }^{642}$ In particular, he portrays the outcome of political equality as a world dominated by uneducated African Americans. ${ }^{643}$ Dixon constructs Reconstruction Columbia, South Carolina, for the reader as a place "crowded with negroes" where "Negro policemen swung their clubs" in the face of white men and regarded every "decently dressed white man" as a spy. ${ }^{644}$ Inside the House of Representatives, "the reek of vile cigars and stale whiskey, mingled with the odor perspiring negroes," and "every black member trying to speak all at once and nothing actually getting done." ${ }^{645}$ The African American majority legislature voted itself additional salaries, to make up for money lost gambling, and introduced a number of bills

\footnotetext{
${ }^{641}$ Dixon, The Clansman, 204-205.

${ }^{642}$ Ibid, 246.

${ }^{643}$ Ibid, 272-273.

${ }^{644}$ Ibid, 163-64.

${ }^{645}$ Ibid, 263-65.
} 
to speed black control of the state. ${ }^{646}$ They include measures to disarms whites and equip a large black militia, making the Confederate uniform the garb of convicts, and forced racial integration in society, including marriage and education. ${ }^{647}$ This interracial legislature stole millions of dollars and bankrupted the state treasury in a matter of weeks. ${ }^{648}$ Dixon uses this incident to demonstrate to his contemporary audience the dangers of African American political equality.

Dixon uses the characters of Abraham Lincoln and Austin Stoneman to represent the parallels the author found in the racial conditions of Reconstruction and those of the early-twentieth century. These two men "above all others who had built and were to build the foundations of the New Nation," play a prominent role in the early part of The Clansman. ${ }^{649}$ Dixon uses their contentious relationship and their characters to explore arguments regarding political equality, federal power, and different visions of the nation's future. Their beliefs, as characters, demonstrate the complexities of Constitutional interpretation and federal power. In The Clansman, Lincoln represents the historical, moderate Republican, as well as the voice of reason and authority on matters of race and sectional unity in the present. President Lincoln possessed no plans for reconstructing the South. As a protector of the Constitution, Lincoln will only do what is necessary to defend the Union. He asserts that the federal government did not have the Constitutional authority to regulate Southern states' suffrage policies, and, thus, opposes

\footnotetext{
${ }^{646}$ Dixon, The Clansman, 268.

${ }^{647}$ Ibid.

${ }^{648}$ Ibid, 272-273.

${ }^{649}$ Ibid, 41.
} 
any plan of Reconstruction. ${ }^{650}$ This message is also aimed at early-twentieth century proequality activists' criticisms of the South's disfranchisement and segregation of African Americans. Austin Stoneman, on the other hand, "hated the President with sullen, consistent, and unyielding venom," and hated the South because "the Satanic Institution of Slavery" "long ago rooted the heart out of the Southern people." 651 In this, Dixon is drawing a comparison between contemporary Northern stereotypes of the South, a sectional bias based in misinformation and vengeful prejudice. Stoneman provides another parallel to Dixon's early-twentieth century by arguing that the Southern states were "but conquered provinces," "waste territories... unfit to associate with civilized communities." In this, he resembles the progressive social reformers of the period, who compared the region to newly acquired territories, and viewed it as a national blight.

To assert Southern capabilities and the region's Constitutional right to self-rule, Dixon's Lincoln disagreed. He claimed that, according to the limits of the Constitution, "a nation cannot make conquest of its own territory" unless the actions protected the Union. ${ }^{652}$ Stoneman viewed social and racial equality as integral to the nation's future as a Union: if Southerners were not disfranchised and African Americans granted political power, the South would "yet reconquer the North" and undo the progress made by the Civil War. ${ }^{653}$ Stoneman claimed Reconstruction would "secure the future of the party and the safety of this Nation" by confiscating "the millions of acres of land owned by the

\footnotetext{
${ }^{650}$ Dixon, The Clansman, 42-44.

${ }^{651}$ Ibid, 40, 53 .

${ }^{652}$ Ibid, 42-44.

${ }^{653}$ Ibid, 52.
} 
white people of the South and its division among the negroes and those who fought and suffered in this war." ${ }^{654}$ Though Dixon surely intended for Lincoln's voice to be the authority in matters of Constitutional interpretation and the limits of federal power, Stoneman's use of Constitutional arguments for political enfranchisement of African Americans demonstrates the flexibility of this rhetoric in both time periods.

Lincoln's vision of the nation's future differed significantly from Stoneman's. The President's plans reinforce Dixon's own leanings towards colonization, and are intended to demonstrate the importance of a white America. Dixon's Lincoln believes in a "physical difference between the white and black races which will forever forbid their living together on terms of political and social equality." Instead, his Emancipation Proclamation represented the first step in a twenty-year plan "to peacefully colonize the Negro in the tropics, and give him our language, literature, religion, and system of government." Through this plan, the black race could "rise to the full measure of manhood," which he "could never do here." Dixon portrayed Lincoln as favoring colonization for the good of the nation, which could "never attain the ideal Union... with millions of an alien, inferior race among us, whose assimilation is neither possible nor desirable." 655 "The Nation," Lincoln maintained, could no more "exist half white and half black, any more than is could exist half slave and half free." ${ }^{.656}$ The President could "conceive of no greater calamity than the assimilation of the Negro into our social and

\footnotetext{
${ }^{654}$ Dixon, The Clansman, 98-99.

${ }^{655}$ Ibid, 45-47.

${ }^{656}$ Ibid.
} 
political life as our equal," for "a mulatto citizenship would be too dear a price to pay even for emancipation." ${ }^{657}$

Simultaneously, these characters and their actions reinforce his earlier arguments against the political legitimacy of Reconstruction. By making Lincoln antiReconstruction, Dixon hoped to prove to his audience that it was never intended to occur. He also labels Stoneman's conception of Reconstruction "the most cruel and awful vengeance in human history," and portrays its policies as the outcome of Stoneman's rejection of the Constitution for being an aristocratic, Southern document. ${ }^{658}$ Black suffrage, however, also resulted from partisan politics. Stoneman believed the life of the Republican Party demanded, "that the Negro be given the ballot and made the ruler of the South." Other vengeful men, such as Edwin Stanton, sought to make the postwar South suffer. ${ }^{659}$ Reconstruction is also possible because of Lincoln's death. ${ }^{660}$ The assassination of "the incarnation of the Triumphant Union" resulted in the masses being "swept from their moorings, and all reason destroyed; All historic perspective was lost." His death triggered a wave of mob violence and anti-Southern sentiment throughout the North. With new Northern public and political acceptance of anti-Southern ideology following the assassination came the opportunity for Stoneman's plan, influenced by his mulatto housekeeper, to be put into place. Reconstruction, as printed in The Clansman, is a national mistake, formed out of opportunity, partisan politics, and personal vengeance.

\footnotetext{
${ }^{657}$ Dixon, The Clansman, 45-47.

${ }^{658}$ Ibid, 39-40, 43.

${ }^{659}$ Ibid, 52; 34, 104-105.

${ }^{660}$ Ibid, 78-79, 81-82, 86 .
} 
It also gave the Federal government far too much power, setting future precedents. This mistake has vast implications; it bore "its harvest of tragedy and death for generation yet unborn," shattering the Union into fragments and creating decades of sectional animosity. ${ }^{661}$

Like The Leopard's Spots, The Clansman perpetuates Dixon's vision of national reunion and a future white nation in a variety of ways, making, he assumed, its message applicable to turn-of-the-century America. He sought to absolve Americans of any blame for the current racial situation, and pleas for a decision on racial matters made on national terms. Historical characters, like Lincoln, continued to be the Anglo-Saxon American hero. With a "good German face," Lincoln is "the idol of the people, the first great American," and the "first great all-around American who ever lived in the White House." ${ }^{662}$ The Civil War President continues, as in the first novel, to be portrayed as "Southern" in character and in sympathies, only favoring federal intervention in the states only because it maintained the Union. Other characters, however, experience a shift in this book. Dixon turned the architect of Reconstruction, his arch-villain in the first installation, into a patriot and honorable father. Though Stoneman "ruled with a rod of iron," "in his personal life, to those he knew, he was generous and considerate. ${ }^{, 663}$ Dixon goes as far as to remove blame for Reconstruction from Stoneman, making the Congressman's actions stem from genuine patriotism. At the beginning of the book, Stoneman believes that Southerners are a "race of traitors" reliant on a "landed

\footnotetext{
${ }^{661}$ Dixon, The Clansman, 41, 145-146.

${ }^{662}$ Ibid, 28, 71-72.

${ }^{663}$ Ibid, 17.
} 
aristocracy." His plans for Reconstruction, including land confiscation and racial equality, ensured that the South could never again undo the Union, making federal intervention in the former Confederacy a matter of "justice," "patriotism," "the highest wisdom and humanity. ${ }^{, 664}$ By the time of his death, Stoneman experienced a change of heart. Stoneman's two children, Phil and Elsie, are his weak spots and help bring about their father's conversion to light Southern sympathies through their inter-regional love affairs. The Lenoir women, whose house he occupied while in the Carolinas, also assist in convincing Stoneman of Southerners' merit. ${ }^{655}$ Dixon further removes Stoneman from responsibility by making Reconstruction the ultimate brainchild of Lydia, the mulatto housekeeper who controls the nation by manipulating Stoneman. ${ }^{666}$ This once again places blame on African Americans and efforts at racial equality.

In addition to absolving Stoneman of guilt, Dixon perpetuated national reconciliation by emphasizing the South and North's common heritage, both racial and historical, and the importance of this reunion to the nation's future. The nation's white colonial heritage, specifically Anglo-Saxon Scottish Covenanters, produced the "largest and most important addition... in the growth of American nationality." ${ }^{\prime 67}$ These early, patriotic settlers were the key to the American Revolution, with their hatred of King George ${ }^{668}$ Early North Carolina, shaped by the democratic ideals of its settlers, became

\footnotetext{
${ }^{664}$ Dixon, The Clansman, 52.

${ }^{665}$ Ibid, 298-299.

${ }^{666}$ Ibid, 94.

${ }^{667}$ Ibid, 187.

${ }^{668}$ Ibid, 342.
} 
"the first home of freedom in the New World." ${ }^{669}$ Dixon also absolves the sections of fault for the Civil War. Like the first novel, the war is portrayed as "the one inevitable thing in our growth from a loose group of sovereign states to a United Nation. ${ }^{, 670}$ For the South, the war's end brought ruin along with an opportunity to "rise to a nobler life than she has ever lived in the past. ${ }^{, 671}$ If the South, and the nation, were to achieve the highest possible levels of progress, however, the South needed to be "healed" and the regional gulf closed. ${ }^{672}$

In Dixon's portrayal, turn-of-the-century race relations were part and parcel of this shared national heritage. No living person held responsibility for the current state of race relations. Rather, the current problems were inherited from several points in history. During the colonial period, "the culture of cotton as the sole industry had fixed African slavery as their economic system," but "God never meant that the Negro should leave his habitat or the white man invade his home." ${ }^{.673}$ The war, an inevitable occurrence in Dixon's formulation, resulted in the foundation of a new country. Southerners were happy slavery was gone, and "the war was not too great a price... for the lifting of its curse. ${ }^{.674}$ Race issues during Reconstruction, however, shattered the peaceful postwar

\footnotetext{
${ }^{669}$ Dixon, The Clansman, 188.

${ }^{670}$ Ibid, 149.

${ }^{671} \mathrm{Ibid}, 66$.

${ }^{672}$ Ibid, 50-51.

${ }^{673}$ Ibid, 189, 146-147.

${ }^{674}$ Ibid, 291.
} 
nation. ${ }^{675}$ By enfranchising African Americans, the radical Reconstruction government made race the central issue of American politics. For Dixon, the biological inferiority of African Americans, a "degenerate" race, was proven by "the grant of the ballot to these millions of semi-savages and the riot of debauchery" following the Civil War. ${ }^{676}$ Reconstruction in the South furthered racial and sectional hatreds, while "to the Yankee the very physical touch of the Negro is pollution."677 Dixon viewed this racial animosity as a national problem, since America's future depended on the purity of its white AngloSaxon stock. ${ }^{678}$

To further strengthen the link between national racial destiny and Southern history, Dixon portrays the actions of the original Ku Klux Klan, as run under the orders of Forrest, as "fighting the battle of a race on whose fate hangs the future of the South and the Nation."679 Dixon's original Ku Klux Klan “is as institution of Chivalry, Humanity, Mercy, and Patriotism" designed to address three particular objects. The first was "to protect the weak... from the wrongs and outrages of the lawless." The second, "to protect and defend the Constitution of the United States." And lastly, "to aid and assist in the execution of all Constitutional laws, and to protect the people from unlawful seizure, and from trial except by their peers in conformity to the laws of the land.. ${ }^{680}$ By

\footnotetext{
${ }^{675}$ Dixon, The Clansman, 145-46.

${ }^{676}$ Ibid, 291-292.

${ }^{677}$ Ibid, 182.

${ }^{678}$ Ibid, 291.

${ }^{679}$ Ibid, 333-334.

${ }^{680}$ Ibid, $320-321$.
} 
portraying the KKK as national saviors, Dixon attempted to make the unsavory elements of Southern history part of a successful American tale of white racial destiny.

Like Dixon's other novels, The Traitor's characters symbolize all of the author's typical tropes: scalawags, carpetbaggers, honorable Southern women and men, the goodbad African American dichotomy, and Northerners. The Grahams, John, Major, and Billy, along with Dan Wiley represent the typical, honorable Southern white man, while Mrs. Wilson and Susie, her daughter, equate to righteous Southern white womanhood. Dixon differentiates between different types of Southern whites, as in the previous novels. In addition to the typical Southern white man, whose dignified family fought in the war, Dixon portrays Steve Hoyle as a scalawag. Hoyle's father avoided service in the war by hiring a substitute, and Hoyle benefitted from and cooperated with the conditions of Reconstruction. The Butlers, the Judge and his daughter Stella, meanwhile, represent poor white trash, having never owned slaves and struggling with financials even after the war. ${ }^{681}$ Different types of Northerners may be found in the characters of Ackerman and Larson. Ackerman represents a Northern intellectual, and assists in uncovering the truth about the Judge's death, while Larkin "was the boldest, most unscrupulous, and powerful carpetbag adventurer who ever entered the South from the slum of the North." ${ }^{682} \mathrm{He}$ also continues perpetuating a good-bad dichotomy in his African American characters. The black figure Isaac A. Postle serves as the "bad" sort, (and a bad literary pun, to boot) easily manipulated and clumsy, yet given political power. Maggie (Stella's maid), and Aunt Julie Ann (the Butler, formerly Graham) cook, both act as "typical" servants of the

${ }^{681}$ Dixon, The Traitor, 27-28.

${ }^{682}$ Ibid, 74-75. 
South, good employees yet not necessarily trustworthy. Only Alfred, the Graham family butler, emerges as the "good," and truly loyal, African American.

It is in Book I of The Traitor that Dixon makes the clear differentiation between the "original" Ku Klux Klan and the "rogue" Ku Klux Klan. By differentiating between the two groups, Dixon could account for the events of history while maintaining his portrait of the KKK as a necessary, honorable implement for national security. The rogue $\mathrm{Ku}$ Klux Klan, in Dixon's formulation, ruined the national reputation of the true Ku Klux Klan. The nation, along with the locals, was largely unaware of the switch between groups, due in part to the KKK's vows of secrecy. Hoyle's new "wildcat Klan” soon controlled the Piedmont, squashing Graham's political campaign for state Congress and inaugurating "a reign of folly and terror unprecedented in the history of the whole Reconstruction saturnalia." They "whipped scalawag politicians," forced "carpetbagger postmasters" out of town, and "whipped Negroes, young and old." This lawlessness and violence, Graham maintained, covered "the name of the KKK with infamy." Dixon reasserts that the original Ku Klux Klan "was the only way to save our civilization," while distancing the organization from lawless behavior after the restoration of Democratic rule during Reconstruction. ${ }^{683}$

Also like its predecessors, The Traitor continued Dixon's criticism of the federal government, emphasizing the limits of its power according to the Constitution. Butler's occupation of the Graham household is one example of the over-extension of this power, as is the general period of Reconstruction. To Dixon, the structure of Reconstruction

${ }^{683}$ Dixon, The Traitor, 95-96; 97; 58. 
governments in North Carolina allowed personal malice, corruption, and the triumph of partisan politics. The original Ku Klux Klan, represented, he insisted, the response to this display of federal power, responsible for restoring the constitutional rights of the state. They are not tried at the highest level, in this tale, because of the corrupt politicians pressing charges know they will not stand against the Constitution. The third part of this narrative portrays the justice system as another corrupt element of Reconstruction, and an example of breaching the Constitution. "The Court," Dixon maintained, "had constituted itself a partisan political tribunal for the purpose, not of administering justice, but of crushing the enemies of the party in power." 684 "In violation of the rights of the prisoner under the constitutions of the state and nation," Graham's trial began almost immediately. The jury, "composed of one dirty, ignorant scalawag and eleven coal-black Negroes," "marked the lowest tide mud to which the administration of justice ever sank in our history." The guilty, though, soon received hasty pardons, for "the little politicians who had forced through Congress the venomous Conspiracy Acts in violation of the Constitution of the Republic did not dare allow the Supreme Court the opportunity to overwhelm them with infamy." 685

As a whole, Dixon intended the Reconstruction Trilogy to function as a tool for national reconciliation and a call to action regarding the race problem. He believed it would convey the importance of an exclusively white-controlled America. Each installation reinforced his central assertions that African American enfranchisement endangered the nation, and that the South and North were equally "American." Dixon

\footnotetext{
${ }^{684}$ Dixon, The Traitor, 304-305.

${ }^{685}$ Ibid, 304-305; 325.
} 
incorporated historical events and characters into the narrative in order to underscore its advertised authenticity, but also to construct a parallel between Reconstruction and the socio-political conditions at the turn-of-the-century. The Trilogy not only portrayed African American voting as dangerous to the nation, it delegitimized the historical and constitutional foundations of guaranteed political equality. Progressive efforts to reform the South through education, combined with increasing federal power and a more active African American community, he argued, recreated Reconstruction era instability. The opportunity to "solve" the race and sectional problems, however, also accompanied this historical parallel. Unlike the outcome of the 1860s debates over race, Dixon hoped the contents of the Reconstruction Trilogy would convince white Americans of the need for segregation and eventual colonization. In addition, Northerners' new familiarity with Southern history and white Southern character might foster a unified Anglo-Saxon nationalism. His message evoked a wide variety of responses from the American public. 


\section{Chapter Five}

\section{Dixon's Anti-Socialism Trilogy (1903-1911)}

During the first fifteen years of the twentieth century, Dixon published another trilogy of novels. The second trilogy completely reversed his previous position on socialism. By 1903, Dixon argued that socialism threatened the nation's socio-economic foundations, by attacking "first the family, the stronghold of individuality, and the bulwark upon which our civilization rests, and then the fiber of the individual himself.",686 Like his previous shifts, Dixon's concerns arose from early-twentieth century trends in American culture and politics. In this period, socialism became a tangible political influence, the Progressive movement reached the height of its political success, high levels of immigration continued to fuel discussions about assimilation, and a "New Woman" emerged to challenge traditional gender norms. To Dixon, these movements reinforced the newfound popularity of "radical socialism."687 This chapter analyzes Dixon's Anti-Socialism Trilogy, revealing that his turn-of-the-century return to conservatism extended beyond issues of race and section. As these novels demonstrate, Dixon viewed ideology, gender, citizenship, capitalism, and nationalism as interlinked concepts that depended on traditional social and economic structures to ensure America's future prosperity.

\footnotetext{
686 "Kinds of Race Prejudice: They Result, Says Dr. Dixon, from Fear of Superior Powers and from Instinct of Self-Preservation," Boston Daily Globe, June 9, 1903.

687 “Truth of History: Rev. Thomas Dixon Defends His Books and Plays,” Lexington Gazette (Lexington, Virginia), October 17, 1906.
} 
Multiple historical developments perpetuated Dixon's belief that socialism was gaining power as a threat to the nation, and could undermine national stability. During the early-twentieth century, several trends emerged in American life that exacerbated Dixon's fears. The years from 1902 to 1912 constituted the "Golden Age of American Socialism" in the United States. ${ }^{688}$ The support of socialist methods occurred alongside increasingly frequent labor violence in the first decades of the twentieth century, which helped to fuel a national conversation about the need for socio-economic reforms. The annual average number of strikes rose from about one thousand a year in the 1890 s to about three thousand a year from 1901 to $1903 .{ }^{689}$ Journalists, politicians, authors, business owners, laborers, and reform activists throughout the country participated. Americans were deeply worried about the future of labor relations, and the debate spread to all levels of society. Labor activists demanded alterations to the current system, arguing for limited work hours and safer conditions, among other changes. In 1903, President Roosevelt asked Congress to authorize the creation of a Department of Commerce and Labor to help stabilize workplace tensions.

While clashes between laborers and business owners continued, corporations developed new popularity and expanded in size and scope. Technological advances and increasing amounts of competition, combined with the rise of professional management, financial depression in the mid-1890s, and the passage of the Sherman Antitrust Act in

\footnotetext{
${ }^{688}$ Daniel Bell, Marxian Socialism in the United States (Princeton: Princeton University Press, 1967), 55.

${ }^{689}$ Jacob Kramer, The New Freedom and the Radicals: Woodrow Wilson, Progressive Views of Radicalism, and the Origins of Repressive Tolerance, (Philadelphia: Temple University Press, 2015), 5.
} 
1890, helped contribute to an explosion in corporations. ${ }^{690}$ Before the Sherman Antitrust

Act, companies had attempted to fight back against unfavorable market trends by forming

trade associations that set policy standards, performed lobbying functions, and allowed

for the sharing of information. The 1891 Antitrust Act, however, made these actions

legally difficult, leaving formal mergers as the readily available option for businesses

looking to combine efforts on the market and in politics. ${ }^{691}$ "The Great Merger

Movement" began shortly after the passage of the Sherman Antitrust Act, peaking

between 1895 and $1904 .{ }^{692}$ During this period, approximately 1,800 firms were

consolidated into 130 corporate entities that controlled anywhere from fifty to seventy

percent of market shares. ${ }^{693}$ A variety of individual states competed to house the

headquarters of these major corporations, eager to attract employment opportunities and

\footnotetext{
${ }^{690}$ For more about the U.S. economy, labor conflict, and corporate industrialization at the turn-of-thecentury, see: Alfred Chandler, Jr., The Visible Hand: The Managerial Revolution in American Business (Cambridge: Harvard University Press, 1977); Naomi R. Lemoreaux, The Great Merger Movement in American Business, 1895-1904 (Cambridge: Cambridge University Press, 1988); Olivier Zunz, Making America Corporate, 1870-1920. (Chicago: University of Chicago Press, 1992); Robyn Muncy, "Trustbusting and White Manhood in America, 1898-1914," American Studies 38, no. 3 (Fall 1997): 21-42; Richard Franklin Bensel, The Political Economy of American Industrialization (New York: Cambridge University Press, 2000); Sven Beckert, The Monied Metropolis: New York City and the Consolidation of the American Bourgeoisie, 1850-1896 (New York: Cambridge University Press, 2001); Robert Harrison, Congress, Progressive Reform, and the New American State (New York: Cambridge University Press, 2004); Charles Perrow, Organizing America: Wealth, Power, and the Origins of Corporate Capitalism (Princeton: Princeton University Press, 2005); Howard Brick, Transcending Capitalism: Visions of a New Society in Modern American Thought (Ithaca: Cornell University Press, 2006); Rosanne Currarino, "The Politics of 'More': The Labor Question and the Idea of Economic Liberty in Industrial America," The Journal of American History, no. 1 (June 2006): 17-36; Greg Urban, ed., Corporations and Citizenship (Philadelphia: University of Pennsylvania Press, 2014); and Robert E. Wright, Corporation Nation (Philadelphia: University of Pennsylvania Press, 2014).

${ }^{691}$ Wright, Corporation Nation, 201.

${ }^{692}$ Walter Licht, "The Rise and Embedding of the Corporation: Considerations for American Democracy and Citizenship," in Corporations and Citizenship, 149-150.

${ }^{693}$ Ibid.
} 
capital. ${ }^{694}$ Corporations, in turn, pressured state legislators to write permissive codes of incorporation allowing the companies to operate across state lines and purchase controlling amounts of stocks in other firms. ${ }^{695}$

Shifts in Progressive Era politics further convinced Dixon of socialism's looming presence. In the mid-1900s and to the beginning of WWI, Progressives interacted frequently with socialism. Following the financial Panic of 1907, Progressives began looking to socialists and syndicalists for input regarding solving labor issues, and did not reject the idea of overhauling the nation's capitalist system. Further, Progressivism and socialism shared several ideological characteristics during the first decade of the twentieth century. Both groups believed that the current capitalist system needed drastic reform to end its exploitative powers, and, thus, quell labor conflicts. They also shared commitments to the idea that workers deserved a voice in business, and using labor unions and strikes to achieve that goal in a cooperative manner. ${ }^{696}$ During the first two decades of the twentieth century, the federal government assumed more responsibility and power to regulate socio-economic issues in state and local jurisdictions. Progressives pushed for expansions of federal power, creating numerous bureaucratic institutions designed to manage issues previously left to local governments. ${ }^{697}$ The National

\footnotetext{
${ }^{694}$ Licht, "The Rise and Embedding of the Corporation," 155.

695 Ibid.

${ }^{696}$ Kramer, The New Freedom and the Radicals, 2-7.

${ }^{697}$ On the expansion of the federal government during the late- $19^{\text {th }}$ and early-20 $0^{\text {th }}$ centuries: Richard Franklin Bensel, Yankee Leviathon: The Origins of Central State Authority in America, 1859-1877 (New York: Cambridge University Press, 1990); Stephen Skowronek, Building a New American State: The Expansion of National Administrative Capacities, 1877-1920 (Cambridge: Cambridge University Press, 1982); Jon C. Teaford, The Rise of the States: Evolution of American State Government (Baltimore: Johns Hopkins University Press, 2002); Steven W. Usselman, Regulating Railroad Innovation: Business,
} 
Reclamation Act of 1902, for instance, sold public land in sixteen states to fund a large irrigation project. Another example, the 1906 Hepburn Act expanded the jurisdiction of the Interstate Commerce Commission by forcing railroad companies to seek federal approval before raising rates. The Mann-Elkins Act (1910) granted the Interstate Commerce Commission even more power by giving it the authority to regulate telephone and telegraph lines. In a complete reversal from his early-1890s support of such measures, Dixon viewed these actions as infringements on individuality and states' rights, a sign of government power running wild.

No consensus emerged about how to solve labor issues, reflecting the presence of multiple reform-minded ideological trends in American culture. Several radical movements favored abolishing portions of the state, such as anarchists, or restructuring the economy to rid the nation of industrial capitalism. ${ }^{698}$ Syndicalism, best represented in the U.S. by the International Workers of the World (also known as "Wobblies" or the IWW), followed Marx in arguing for the seizure of the means of production by the workers and believed in strikes to accomplish this goal. ${ }^{699}$ In addition, a politically viable

Technology, and Politics in America, 1840-1920 (New York: Cambridge University Press, 2002); Peter Zavodnyik, The Rise of the Federal Colossus: The Growth of Federal Power from Lincoln to F.D.R. (Santa Barbara: Prager, 2011); Paul D. Moreno, The American State from the Civil War to the New Deal: The Twilight of Constitutionalism and the Triumph of Progressivism (Cambridge: Cambridge University Press, 2013); Johnathan O'Neill, "The Idea of Constitutional Conservatism in the Early Twentieth Century," in Paul D. Moreno and Johnathan O'Neill, eds., Constitutionalism in the Approach and Aftermath of the Civil War (New York: Fordham University Press, 2013), 202-222; Ajay Mehrota, Making the Modern American Fiscal State: Law, Politics, and the Rise of Progressive Taxation, 1877-1929 (New York: Cambridge University Press, 2013); Daniel R. Ernst, Toqueville's Nightmare: The Administrative State Emerges in America, 1900-1940 (New York: Oxford University Press, 2014); Carol Nackenoff and Julie Novkov, eds., Statebuilding From the Outside In: Between Reconstruction and the New Deal (Philadelphia: University of Pennsylvania Press, 2014); and Jeffrey W. Meiser, Power and Restraint: The Rise of the United States, 1898-1941, (Washington, D.C.: Georgetown University Press, 2015).

${ }^{698}$ Kramer, The New Freedom and the Radicals, 8.

${ }^{699}$ Ibid, 9-10. 
Socialist Party formed in this period, and nominated candidates in national elections. Led by Eugene V. Debs, the early-twentieth century Socialist Party in America was unique in its emphasis on individuality and gender-free and colorblind invitation to potential members. ${ }^{700}$ Corporations were regarded as the element of disruption, and the Socialist Party called for a restoration of traditional individual freedom by instilling a broad system of collective democratic ownership. ${ }^{701}$ The Socialists also desired a minimum wage, shorter workweek, safety inspections, women's suffrage, and the elimination of child labor. ${ }^{702}$ Women, African Americans, immigrants, and white laborers were all attracted to the Socialist Party and the Wobblies, and their participation assisted in strengthening radical organizations in the U.S.

In addition, a visible movement of women's activists in this period began demanded political and social rights previously denied to them based on traditional gender roles. These reformers aspired to economic independence, suffrage rights, sexual freedom, and identities separate from the notion of family. ${ }^{703}$ The ideals of the "New

\footnotetext{
${ }^{700}$ Nicholas Salvatore illustrates this point in Eugene V. Debs: Citizen and Socialist (Chicago: University of Illinois Press, 2007).

${ }^{701}$ Ralph Young, Dissent: The History of an American Idea (New York: New York University Press, 2015), 315-316.

${ }^{702}$ Ibid.

${ }^{703}$ For more on early-twentieth century feminism, see: Corrine M. McConnaughy, The Woman Suffrage Movement in America: a Reassessment (New York: Cambridge University Press, 2013); Ann Heilmann and Margaret Beetham, eds., New Woman Hybridities: Femininity, Feminism, and International Consumer Culture, 1880-1930 (New York, Routledge, 2004); Christina Simmons, "Women's Power in Sex Radical Challenges to Marriage in the Early-Twentieth Century United States," Feminist Studies 29, no. 1 (Spring 2003): 168-198; Michael S. Kimmel, "Men's Responses to Feminism at the Turn of the Century," Gender and Society 1, no. 3 (September 1987): 261-283; and Gerald L. Marriner, "The Feminist Revolt: The Emergence of the New Woman in the Early-Twentieth Century," Humboldt Journal of Social Relations 1, no. 2 (Spring/Summer 1974): 127-134.
} 
Woman" broke from the gendered spheres of the Victorian era, where women were expected to influence society by proxy as mothers and wives. Early-twentieth century versions of feminism operated in many formats, from relatively conservative to radical, and every combination in between. Some groups emphasized improving women's domestic conditions through behavioral changes aimed at eliminating vice, such as temperance laws and eliminating prostitution, but did not advocate measures like equal voting rights. ${ }^{704}$ Other participants pushed for larger deviations from the status quo, such as "freeing" women at large from the repression of society's traditional structures of marriage and motherhood. ${ }^{705}$ A Marxist element of the movement viewed marriage and motherhood as fundamental girders of capitalism, and, this, rebellion against them as key to a larger socialist or communist effort. ${ }^{706}$

The "New Woman" was part of a significant early-twentieth century alteration in morals. Urbanization and industrialization upended the structure of moral authority in U.S. society. In previous decades, local communities and the family determined the

\footnotetext{
${ }^{704}$ For more on vice-focused reform efforts, see: Mara L. Keire, For Business \& Pleasure: Red Light Districts and the Regulation of Vice in the United States, 1890-1933 (Baltimore: Johns Hopkins University Press, 2010); Scott C. Martin, Devil of the Domestic Sphere: Temperance, Gender, and Middle-Class Ideology, 1800-1860 (DeKalb: Northern Illinois University Press, 2008); Joe L. Coker, Liquor in the Land of the Lost Cause: Southern White Evangelicals and the Prohibition Movement (Lexington: University Press of Kentucky, 2007); Brian Donovan, White Slave Crusades: Race, Gender, and Anti-vice Activism, 1887-1917 (Urbana: University of Illinois Press, 2006); Catherine Gilbert Murdock, Domesticating Drink: Women, Men, and Alcohol in America, 1870-1940 (Baltimore: Johns Hopkins University Press, 1998); Alison M. Parker, Purifying America: Women, Cultural Reform, and Pro-Censorship Activism, 1873-1933 (Urbana: University of Illinois Press, 1997); and Janet Zollinger Giele, Two Paths to Women's Equality: Temperance, Suffrage, and the Origins of Modern Feminism (New York: Twayne Publishers, 1995).

705 Simmons, "Women's Power in Sex Radical Challenges to Marriage in the Early-Twentieth Century United States," 174; see also: Nathan Q. Ha, "The Riddle of Sex: Biological Theories of Sex Difference in the Early Twentieth Century," Journal of the History of Biology 44, no. 3 (Fall 2011): 505-546.

${ }^{706}$ Simmons, "Women's Power in Sex Radical Challenges to Marriage in the Early-Twentieth Century United States," 179.
} 
parameters of moral acceptability, but urban life and work changed social relationships by offering opportunities for individuals to determine their own behavioral norms. ${ }^{707}$ American women spent increasing amounts of time outside the home and by entering the workforce, leading to more socio-economic independence. A revolution in acceptable social behavior followed. Previously deemed taboo in public, subjects like birth control, prostitution, divorce, and sexuality, became increasingly commonplace in magazines and articles. Smoking and drinking, too, became fashionable among women of all ages. ${ }^{708}$ These new trends provoked a myriad of behavioral control suggestions by civic officials and conservative-minded citizens that included banning alcohol, dancing, cabarets, and birth control, alongside censoring the media. ${ }^{709}$

To Dixon, these developments challenged traditional socio-economic structures of such as marriage, free labor, and free markets, and could be categorized as socialist. In Dixon's view, these strengthening socialistic trends in society equated to "a problem far greater than the Negro question" because "it affects society at large." "710 The AntiSocialism Trilogy consisted of three books, The One Woman (1903), Comrades (1909), and The Root of Evil (1911). The first installation of Dixon's trilogy about socialism appeared on shelves in 1903, titled The One Woman. The One Woman is narrated in a series of chronological chapters, rather than separate parts, and narrates a story about the meaning of love, marriage, jealousy, and the limits of human nature. The tale follows the

\footnotetext{
${ }^{707}$ McGovern, “The American Woman's Pre-World War I Freedom in Manners and Moral,” 316-320.

${ }^{708}$ Ibid.

${ }^{709}$ Ibid, 328-332.

710 "An Interview with Thomas Dixon, Jr.," The Charlotte Observer (Charlotte, North Carolina), October 20, 1906.
} 
deadly love triangle of main character Frank Gordon, a Christian Socialist reformer, and his love interests, childhood sweetheart and wife, Ruth, and Kate, a young lady who championed the causes of the New Woman. The One Woman is set in present day New York, where Frank sought to instigate a "revolution that shall redeem society" with "new forms of Social freedom." ${ }^{711}$ The first institution he sought to change was traditional, lifelong marriage. Frank believed marriage was "a fetish... a foundation of corruption, and was the source of the monopolistic instincts" plaguing humanity. ${ }^{712}$ A new process of union provided the base for Frank's "prophecy of a redeemed society in which love, fellowship, comradeship, and brotherhood shall become the laws of life." ${ }^{, 713}$ An integral part of Frank's revolutionary plan included modifying the family "in the evolution of human freedom" by elevating "womanhood from enslavement to form, ceremony, and tradition" to "the mate and equal of man.", 714 Not only did Frank desire equal power dynamics in marriage, he argued that marriage contracts could be broken at will by either participant in order to enable the ultimate sort of freedom. He divorced his wife, Ruth, in favor of more like-minded lady named Kate. Frank's idealistic form of society, however, failed to manifest as planned. His new wife, empowered by the terms of Frank's idealistic union, left him for another man. Frank reacted violently to Kate's dalliance by murdering her new lover, breaking the limits of his civility and the law. After his

\footnotetext{
${ }^{711}$ Thomas Dixon, The One Woman: A Story of Modern Utopia (New York: Doubleday, Page, 1903), 159160 .

${ }^{712}$ Ibid, 185-186.

${ }^{713}$ Ibid, 194.

${ }^{714}$ Ibid, 194, 161.
} 
acquittal in court, Frank reignites a relationship with his first wife, who turns out to be "the one woman" after all.

In the second installation of this trilogy, Comrades: A Story of Social Adventure in California (1909), Dixon narrated the tale of a failed utopian colony. A variety of such utopian colonies peppered the U.S., representing small-scale attempts at demonstrating the outcome of a different socio-economic system. ${ }^{715}$ Contemplating the potential of different utopian systems became a commonplace theme in American fictional literature: more than one hundred and fifty utopian novels were published from the late-1880s to $1900 .^{716}$ Comrades traces the conception, establishment, and fall of the state of Ventura, a socialist colony on an island off the coast of California in 1899. The main characters in this novel are Norman Worth, his love interest, Barbara Bozenta, his father, the Colonel, and a married couple, Hermann and Catherine Wolf. Like The One Woman, Comrades is not divided into parts, but told in a series of consecutive chapters. It begins with

\footnotetext{
${ }^{715}$ For more information about utopian communities in this period, see: Robert P. Sutton, Communal Utopias and the American Experience: Secular Communities, 1824-2000 (New York: Praeger, 2004); Clifford F. Thies, "The Success of American Communes," Southern Economic Journal 67, no. 1 (July 2000): 186-199; Donald E. Pitzer, ed., America's Communal Utopias (Chapel Hill: University of North Carolina Press, 1997); Robert S. Fogarty, All Things New: American Communes and Utopian Movements, 1860-1914 (Chicago: University of Chicago Press, 1990); Robert H. Walker, Reform in America: The Continuing Frontier (Lexington: University Press of Kentucky, 1985); and Charles J. Rooney, Jr., Dreams and Visions: A Study of American Utopias, 1865-1917 (New York: Praeger, 1985).

${ }^{716}$ Susan L. Mizruchi, The Rise of Multicultural America: Economy and Print Culture, 1865-1915 (Chapel Hill: University of North Carolina Press, 2008), 256; On utopianism in this period's popular culture, see also: M. Giulia Fabi, "Desegregating the Future: Sutton E. Griggs' Pointing the Way and American Utopian Fiction in the Age of Jim Crow," American Literary Realism 44, no. 2 (Winter 2012): 113-132; Gib Prettyman, "Gilded Age Utopias of Incorporation," Utopian Studies 12, no. 1 (2001): 19-40; Elmer Suderman, "Utopia, The Kingdom of God, and Heaven: Utopian, Social Gospel, and Gates Ajar Fiction," American Studies 31, no. 1 (Spring 1990): 91-101; Jean Pfaelzer, The Utopian Novel in America, 18861896: The Politics of Form (Pittsburgh: University of Pittsburgh Press, 1984); Kriss A. Drass and Edgar Kiser, "Structural Roots of Visions of the Future: World-System Crisis and Stability and the Production of Utopian Literature in the United States, 1883-1975," International Studies Quarterly 32, no. 4 (December 1988): 421-438; Kenneth M. Roemer, The Obsolete Necessity: America in Utopian Writings, 1888-1900 (Kent: Kent State University Press, 1976)
} 
Norman's adoption of socialism and his subsequent idea to buy an island, establish a steamship line and plant a colony of ten thousand to found "the Brotherhood of Man," which would serve as a model city and "create a vast fund for the propaganda of our [socialists'] faith." ${ }^{, 717}$ The Colonel Worth, though disapproving of his son's ideals, appreciated Norman's enthusiasm. He secretly funded Norman's island project, donating a million dollars to the cause on the conditions that Norman hold the deed for two years and that half of the money would remain in a trustee fund for the operation of the colony. $^{718}$

The bulk of Comrades is devoted to describing the various ways the socialist adventure goes awry. From the moment Norman published the first recruitment ad for the colony, he faced series of complicated challenges. The first was choosing the initial group of citizens from the gigantic pile of applications, twenty-five thousand from "every ism of all the philosophies past and present." ${ }^{, 719}$ Norman tasked his mentors from the Socialist Club, the Wolfs, with choosing the initial two thousand colonists. This couple played his second-in-command throughout, but was actually plotting to eventually seize power from Norman. Once on the island, the distribution of work assignments and determining wages emerged as the next major obstacle. The island's existing housing and leftover equipment from previous owners, which included "a hotel for more an one hundred thousand guests, vineyards, a winery, orchards, flour mills, an ice factory, and

\footnotetext{
${ }^{717}$ Thomas Dixon, Comrades: A Story of Social Adventure in California (New York: Grosset and Dunlap, 1909), 53-54.

${ }^{718}$ Ibid, 102-108.

${ }^{719}$ Ibid, 110-120.
} 
mining and manufacturing enterprises," provided the basic infrastructure for the experiment's success. ${ }^{720}$ This left four necessary categorizations of labor: "Production, Distribution, Domestic Service, and Education.” After casting two sets of secret ballots, however, every member of the Brotherhood refused "to do the dirty and disagreeable work," putting the new community in a conundrum. No one would volunteer for undesirable work without "the payment of extraordinarily high wages," but "if wages were made unequal, the old problem of inequality would remain unsolved." Norman appointed an executive council to solve this issue, comprised of the Wolfs, Barbara, and another member, which decided to "fix wages on an unequal basis" rather than reduce its unwilling members to "a condition of involuntary labor, which is merely a long way to spell slavery." 721

In the coming weeks, though, negotiating wages and labor regulations caused partisan divides and civil disorder in the Ventura colony, culminating in the emergence of a tyrannical communist state. Discontent over perceived inequalities led to a spat of strikes and widespread civil misbehavior, such as public drunkenness, robberies, and gossip. ${ }^{722}$ A group of vegetarians, for instance, insisted on inspecting the cooks' kitchens, while pro-temperance colonists destroyed five hundred mince pies because they contained brandy. In response, the "commission on nuisances" issued a code of laws regulated the ingredients for each meal, setting a pattern. In the coming weeks, they erected rules for the kinds of pets allowed, passed a code requiring uniform dress for each

\footnotetext{
${ }^{720}$ Dixon, Comrades, 114-115.

${ }^{721}$ Ibid, 135-136; 144-146; and 151-152.

${ }^{722}$ Ibid, 186-187.
} 
gender, and dictated the conduct of all social gatherings. ${ }^{723}$ After the murder of one man by another in a quarrel over a woman, the executive committee decided to build a penal colony on a small outpost, launch an investigative agency to ensure compliance with laws, and institute the whipping post for minor offenders. Still, discontent over wealth distribution and behavioral codes bubbled into a farmers' strike that led the executive council to call an assembly meeting. ${ }^{724}$

In the final portion of Comrades, Norman is ousted from power. The assembly meeting to deal with the strike established a new government authority system, reliant on a board of governors and two supervising regents. Claiming their plan is "to save the colony" from ruin at the hands of a "bungling amateur," the new board and the Wolfs (serving as regents) deposed Norman. ${ }^{725}$ " The island's economic framework was revamped to include equal wages, free food, clothes, housing, and five hundred dollars a year at the Brotherhood store. Simultaneously, labor regulations and government authority were strengthened with a new article to the Ventura constitution requiring "every citizen of the State must labor according to his ability" and warning "those who can work and will not shall be made to work." ${ }^{726}$ Under this new system, "the discipline of an army was strictly enforced," bringing the island back into a peaceful working order. Under the Wolfs, the island becomes a virtual prison. A strict double patrol around each community and curfews rendered "escape from the island or communication with the

\footnotetext{
${ }^{723}$ Dixon, Comrades, 181-190.

${ }^{724}$ Ibid, 205-206.

${ }^{725}$ Ibid, 263-264.

${ }^{726}$ Ibid, 231-235.
} 
coast more impossible than ever."727 Two months of Wolf"s "merciless rule" efficiency in the workplace plummeted, and "the entire colony gradually gravitated to the basis of convict service."728 Wolf planned to install "the reign of pure Communism, which is the only logical end of Socialism," including the abolition of private property, the end of legal marriage, freedom in sexual mores, and state regulation of the birth rate. ${ }^{729}$ The narrative concludes with Norman giving up on the experiment. With the help of Barbara, Norman sends a distress telegram to his father and, shortly after, the U.S. Army landed on the island to transport its people back to the mainland. ${ }^{730}$

Since Dixon defined socialism in a broad sense, his third novel, The Root of Evil, centered on the negative long-term social effects of corporate capitalism. It follows the participants in a love triangle from 1898 to 1907: James Stuart, a lawyer in New York, his fiancé Nan Primrose, and James' college acquaintance, Wall Street businessman John C. Calhoun Bivens. The increasing power and prevalence of corporations at the turn-ofthe-century, and the accompanying dramatic shifts in American social norms, played a central role in their story. Set in New York, with brief interludes in North Carolina, The Root of Evil is divided into three "books." In Book I, "The Seed," James lost his fiancé to his former collegiate buddy after the couple disagreed over their future lifestyle. Nan demanded James become a "man of wealth and power... if for no other reason than

\footnotetext{
${ }^{727}$ Dixon, Comrades, 283-285.

${ }^{728}$ Ibid, 206-207.

${ }^{729}$ Ibid, 309-310.

${ }^{730}$ Ibid, 310-319.
} 
because I wish it." ${ }^{, 731}$ She called off their engagement, even though she still loved James, after he refused to take a lucrative position in Bivens' company. ${ }^{732}$

James' refusal to work for Bivens stems from his neighbor's experience with one of Bivens' trusts, the American Chemical Company. Dr. Henry Woodman, a Civil War veteran and "manufacturing chemist," ran a family business that "had been a pioneer in the establishing of a trade in pure drugs." ${ }^{, 733}$ Woodman received "an ultimatum from the Chemical Trust" to sell his family factory, at above market value, or "get off of the earth." The doctor did not want to accept and called James for legal advice on how to avoid joining Bivens" business trust and helping the corporation "rob" the neighborhood. James opposed Bivens' company on the grounds of his friendship with Woodman and because he idea of becoming "the hireling of a corporation" made him uncomfortable. ${ }^{734}$ After Nan married Bivens, James decided win her back "through the law of might."

Book II, “The Root," picks up nine years later, after Nan's marriage to Bivens. She had become the "sensation of the metropolis" while Bivens gathered more wealth. Nan kept in close contact with her ex-fiancé through weekly letters and asked James to visit. ${ }^{735}$ Since their last meeting, James entered politics and his attack on corruption as District Attorney left him "one of the foremost figures in American Democracy—the best loved and the most hated and feared men in public life in New York." His dedication to

\footnotetext{
${ }^{731}$ Thomas Dixon, The Root of Evil: A Novel (Garden City, New York: Doubleday and Page, 1911), 28.

${ }^{732}$ Ibid, 62-93.

${ }^{733}$ Ibid, 10-12.

${ }^{734}$ Ibid, 13-17; 35.

${ }^{735}$ Ibid, 92-93; 110-113.
} 
the people made him "the most powerful man who had ever held such an office" and his most recent case sought to uncover "criminal acts of a group of the most daring and powerful financiers of the world." Bivens offered James a cache of insider documents with potential to "shake the foundations of the financial world" and earn James enough political clout to propel him into a presidential bid. Upon further investigation, James discovered "Bivens had only scratched the surface of the truth" and he set about prosecuting one of the offenders. ${ }^{736}$ The indictment of the president of a prominent corporate trust resulted in stock market panic and media outrage. The panic, it turns out, resulting from purposeful orchestration on the part of Bivens and his cohort, "who rode the storm it had created." James' popularity plummeted in response; to the public, it appeared he "either willfully and corruptly played into the hands of a powerful group of millionaires or had blunderingly done so." ${ }^{, 737}$ Bivens' reign of economic terror, though, came to an abrupt halt after another incident with Dr. Woodman. Woodman stole a batch of expensive party favors from Bivens' house after the Wall Street magnate again refused to compromise. Charged with theft, Woodman requests James' assistance in court. Thanks to James' help, Woodman walked out of the courtroom without chains. Bivens experienced a severe stroke upon conclusion of the trial. ${ }^{738}$

The final part of The Root of Evil, "Book III: The Flower," wraps up the story. At Bivens' request, James began spending more time with the married couple. After a yachting and hunting expedition, James and Nan realized they still loved each other.

\footnotetext{
${ }^{736}$ Dixon, The Root of Evil, 110-113.

${ }^{737}$ Ibid, 182-185.

${ }^{738}$ Ibid, 284-314.
} 
James, skeptical of her motive asked Nan to prove her love by leaving Bivens, but she would not. ${ }^{739}$ Harriet Woodman, the doctor's daughter, and James showed some interest in one another, sparking an intense jealousy in Nan. In the coming weeks, Bivens' health mysteriously failed. Upon Bivens' death, James realized that Nan had murdered her husband in an attempt to be with him and keep her current wealthy lifestyle. Appalled, he ended their relationship and built a life with Harriet. ${ }^{740}$

There is a level of ideological and stylistic continuity in the Anti-Socialist Trilogy. Certain elements of Dixon's ideology, as presented in the earlier group of novels, remain prevalent in the second set. He consistently discussed progress, as before, as well as corruption, individualism, the power of the media, human nature, white supremacy, and the downfalls of modernity. In all three novels, Dixon adheres to a masculine, white nationalist definition of citizenship that emphasizes democratic education, human nature, and traditional gender norms, similar to that espoused in the previous trilogy. Dixon believed a well-educated, white, male voting citizenry, ruled by a Protestant moral compass, provided the key to America's global success. The AntiSocialism Trilogy also contains autobiographical, historical, and romantic elements to present its message as accurate to the readers. Dixon branded himself an authentic source of information about socialism, claiming to have studied the "accursed doctrine" and "the negro problem in the South," subjects he labeled his "two great hobbies," for years. ${ }^{741}$

\footnotetext{
${ }^{739}$ Dixon, The Root of Evil, 316-350.

${ }^{740}$ Ibid, 354-407.

741 “An Interview with Thomas Dixon, Jr.," The Charlotte Observer (Charlotte, North Carolina), October 20, 1906; "Author of 'The Clansman' Visits San Francisco: Thomas Dixon, Who Writes on Socialism and Negro Problem," San Francisco Chronicle, June 17, 1908.
} 
He claimed to have "bought a copy of every book... on socialism and had read them all through before I wrote The One Woman."742 This tactic of emphasizing research methods and personal experience permeated both of the trilogies.

Dixon's Anti-Socialism novels further demonstrate his ideological return to socioeconomic conservatism in the early-twentieth century, as well as the way in which he linked white nationalism to this conservatism. There is a clear deviation from his years in the ministry, when Dixon identified as a "rabid socialist."743 He credited this shift to the work of Edmond Demolins, a French educationalist whose Anglo-Saxon Superiority: To What it is Due, was first translated into English in $1897 .^{744}$ Demolins' argument left Dixon "thinking in the other direction," he insisted, and "now I hate socialism with an uncompromising fury." ${ }^{, 75}$ Demolins' work distinguished between Anglo Saxons, "Celts," and "Normans," arguing that the character of the Anglo Saxon race accounted for its global superiority. ${ }^{746}$ The author maintained that Celts and Normans subscribed to a "Communistic formation" of society, weakening the "lower classes by dragging them into laboring pauperism" and "the upper classes by promoting Lordolatry, Patronage, and

\footnotetext{
742 “An Interview with Thomas Dixon, Jr.," The Charlotte Observer (Charlotte, North Carolina), October 20, 1906.

${ }^{743}$ Ion Clifford, "Rockefeller a Hero of Romance: Thomas Dixon Outlines a Trilogy on SocialismExplains Lesson of His Negro Trilogy,” New York Times, August 10, 1907.

744 There is, sadly, a limited English-language historiography on Demolins, though he appears frequently in French language. Most English-language studies of Demolins discuss race relations and nationalism, particularly in those focusing on France, Britain, Egypt, Turkey, and/or Syria. There is little regard to his longterm impact in the United States.

${ }^{745}$ Ion Clifford, "Rockefeller a Hero of Romance: Thomas Dixon Outlines a Trilogy on SocialismExplains Lesson of His Negro Trilogy,” New York Times, August 10, 1907.

${ }^{746}$ Edmond Demolins, Anglo-Saxon Superiority: To What it is Due, Translated by Louis Bert Lavigne (New York: R.F. Fenno \& Company, 1898), v-viii.
} 
Snobbery." Anglo Saxons, on the other hand, gradually overcame the influences of Celts and Normans, and belonged to "the Particularistic formation," where "the individual is made to prevail over the community, private life over public life, and in consequence the useful profession over the liberal and administrative professions. ${ }^{, 747}$ For Demolins, socialism represented an outdated "manifestation of the Communistic formation, which leads men to seek redress of social evils by help of the group, the community, rather than by the activity of the individual." He believed that future progress relied on the development of greater energy, independence, self-restraint, and self-respect in the individual. ${ }^{748} \mathrm{He}$ hoped to make the "new trilogy a complete glorification of individualism." 749

In The One Woman, the first of the novels in this series, Dixon attempted to "outline the influence of Socialism on the family." critiqued formal socialist ideology as a threat to traditional marriage and the American family, which he interpreted as the cornerstones of capitalist civilization. He linked the emerging women's movement of the early-1900s with the rise of socialist sentiment at large. Dixon argued that socialism and "free love" were interwoven concepts, and that the establishment of such policies in the U.S. could lead only to communism by disrupting traditional gender relationships. In this work, Dixon focuses his criticism on the Christian elements of the socialist movement. It follows a small cast of characters,

${ }^{747}$ Demolins, Anglo-Saxon Superiority, v-viii.

${ }^{748}$ Ibid.

${ }^{749}$ Ion Clifford, "Rockefeller a Hero of Romance: Thomas Dixon Outlines a Trilogy on SocialismExplains Lesson of His Negro Trilogy," New York Times, August 10, 1907.

${ }^{750}$ Ibid. 
focusing primarily on a web of romantic entanglements between five people. Each character represents a different aspect, as Dixon interprets them, of the early-twentieth century debates regarding the future trajectory of socialism in the United States and about the shape of modern gender roles. As the narrative unfolds, Dixon uses his characters to present different aspects, as he perceives them, of arguments regarding socialism. At the story's end, traditional gender roles and individual characters' honor emerged as key parts of the nation's continuing battle against the threats of socialist ideology.

Like Dixon's previous works, this novel has a central focus on romantic plots and character dialogue to communicate its primary argument. Frank Gordon, the main male character, represents the idealistic Christian Socialist reformers of the early-twentieth century. Dixon portrays Frank as flawed and rushed, an ill-informed and naïve young man endangering the nation with his ill-conceived attempts at revolution. "Emotional thinking" characterized Frank, "an idealist and a dreamer" from Southern Indiana with a penchant for pretty women. ${ }^{751}$ Throughout the novel, Frank's feelings undergo a series of changes in regards to the relationship between socialism and marriage. Parallels to Dixon's life appear consistently throughout the book, making up a large portion of Frank's persona. The fictional minister shares several traits with Dixon's own beliefs and career during the 1890s. Like Dixon, Frank Gordon became a local celebrity in a New York City church, where he attracted large crowds as "the impulsive champion of the people, the friend of the weak" and "the patriot prophet of a larger democracy." ${ }^{, 752}$ Frank is popular, attracting large crowds and plenty of newspaper attention, yet controversial

\footnotetext{
${ }^{751}$ Dixon, The One Woman, 4-5.

${ }^{752}$ Ibid.
} 
for "preaching Christian Socialism." ${ }^{, 753}$ Further similarities manifest in Frank's career. He challenges church leaders to eliminate pew-rents, and criticizes the established Christian denominations for failing to address the problems of urban modernity. ${ }^{754}$ His sermons are accused of including "no Bible in them—only personalities and rank Socialism," which angered the older church members and trustee board. ${ }^{755}$ Another autobiographical element is clear in Frank's desire to build his own church, "a flaming center of Christian Democracy" designed to "flash its glory from the sky above the sordid materialism that is crushing the lives and hearts of men." ${ }^{756}$ Frank, like Dixon in the 1890 s, believed church and social reforms were vital for the nation's future. The One Woman spends substantial time tracing the effects of Frank's actions on his friends and family, using their story as a cautionary tale against socialist ideology. Intersecting romantic plots in The One Woman partially drive Frank's turn toward socialism, and reveal the different masculine and feminine types Dixon constructed in the novel's main characters. Frank has two primary love interests, as well as two male competitors for female attention. In the character list, Dixon described the female characters as "the one woman," Frank's wife Ruth Gordon, and "the other woman," named Kate Ransom. Ruth's character represents Dixon's ideal woman: Southern and dedicated to family and marriage in the traditional manner, though a bit jealous. She is the victim of Frank's decision to support Christian Socialism, and her persistence in

\footnotetext{
${ }^{753}$ Dixon, The One Woman, 13.

${ }^{754}$ Ibid, 48, 118.

${ }^{755}$ Ibid, 13.

${ }^{756}$ Ibid, 15-16.
} 
loving her husband after his neglects his martial obligations make her Dixon's epitome of feminine dedication and proper behavior. Women like Ruth, in Dixon's formulation, should be cherished by the nation. Kate's character, on the other hand, resembles the "New Woman" emerging in the early-twentieth century. She favors equal political standing for women, and supports Frank's socialist ideals, making her rebellious in nature by Dixon's standards. In a bit of foreshadowing, Kate is also described as "the type of woman who enraptures the senses, drugs the brain and conscience of the man who responds to her call — the woman about whom men have never been able to compromise, but have always killed one another." ${ }^{757}$ By the tale's end, Dixon makes it clear to the reader why Ruth's brand of feminine values, rather than Kate's, is the ideal.

The three main male characters each represent a different interpretation of masculine values. Dixon presents Frank as a symbol of socialism's flawed masculine values: a man interested in upending the traditional familial system by standing on equal footing with women. Two other men emerged as alternative love interests in place of Frank: Frank's close friend, Mark Overman, and Ruth's childhood sweetheart, Morris King. Mark Overman stands for an older, conservative masculinity, albeit a semidysfunctional one. He is Kate Ransom's other male love interest, though at the story's outset this seems unlikely. A one-eyed Wall Street banker several times a millionaire, intelligent, famous for his brutally cynical wit, and for ridiculing socialist reformers, Mark held two things in "special pride — hatred for women and a passionate love for game cocks." ${ }^{758}$ Mark's anti-female mindset stems from an irrational fear of women's

${ }^{757}$ Dixon, The One Woman, 11.

${ }^{758}$ Ibid, 28-29. 
intuition. "I hate women," he confessed in a conversation with Frank, "because I'm afraid of them... Women have an x-ray in their eyes... A man learns a thing is true by a painful process of reasoning. A woman knows a thing is so-because!" ${ }^{, 75}$ In many ways, Mark is the opposite of Frank's masculinity and ideology. Presenting "a sharp contrast to the ideal of Gordon [Frank]," Mark Overman exhibited "remorseless logic," "thorough scholarship," an admirable "grasp of history," and a "savage common sense." ${ }^{, 760}$ He despises socialism, serving as Frank's intellectual parallel. The banker's staunch dislike of women, however, ends when he begins spending time with Kate.

The character of Morris King symbolizes Dixon's ideal man: hard working, devoted, smart, loyal, and successful. Morris is morally conservative, "a teetotaler" with "no redeeming vices." ${ }^{.761}$ Morris and Ruth Gordon were childhood sweethearts in Virginia, and the two planned on marriage. After meeting Frank, however, Ruth ended her engagement to Morris. ${ }^{762}$ Morris left Virginia shortly afterward for New York. In the city he became a successful lawyer and local political leader. Morris King received the Tammany political machine's endorsement for Governor of the state, and he held presidential aspirations. The successful man never lost his love for Ruth, and Morris pursues her while Frank undergoes his socialist revolution. Ruth, Morris claims, is actually his lifetime inspiration "to be a great man." ${ }^{, 763}$ Morris' character balances

\footnotetext{
${ }^{759}$ Dixon, The One Woman, 33-34.

${ }^{760}$ Ibid, 228-229.

${ }^{761}$ Ibid, 211.

${ }^{762}$ Ibid, 213.

${ }^{763}$ Ibid, 214-215.
} 
Frank's marital neglect by caring for Ruth monetarily and emotionally after Frank left her for Kate. Throughout the novel, Morris King portrays the selfless and committed male savior of Ruth, as well as a hard-working and shrewd politician.

A variety of smaller subthemes, each connected to socialism in some way, continuously appear throughout The One Woman. As the tale unfolds, each of Dixon's characters wrestles with ideas of materialism, the role of gender in society and politics, the meaning of marriage, the concept of individual character, political corruption, and the limits of loyalty. Throughout this work, he views traditional family structures and gender roles as critical elements of the nation's foundation of individualism and private property. The growth of socialist ideals, he argues, threatened to upend the established sociopolitical structure by restructuring marriage and power relationships with the family. The two concepts, in his view, were inextricably intertwined. From the outset, Dixon makes socialism and traditional marriage incompatible. In the opening scenes, Ruth and Frank already display signs of marital stress. Frank's “enthusiasm for the Socialistic ideal was fast becoming an absorbing passion, and was destined to lead him into strange company. His wife felt this, resented it, and, become more and more conservative, the gulf between them daily widened and deepened."764 This "strange company" arrived as Kate Ransom. While working together at the Baptist church, Kate and Frank fell in love. She secretly donated half of her inheritance, a million dollars, to fund Frank's temple. Upon realizing her role in its construction, Frank decided to "defy the world" by divorcing Ruth and

\footnotetext{
${ }^{764}$ Dixon, The One Woman, 19-20.
} 
refusing to "live with one woman and love another." ${ }^{, 765}$ Ruth protested, but eventually gave in to Frank's divorce request. Kate and Frank linked themselves in a new wedding ceremony, which proclaimed "the dawn of a higher life for all, the sanctity and omnipotence of love. ${ }^{, 766}$

One of the largest themes in the novel is the idea of progress. Throughout the narrative, Dixon makes it clear that the country is in the midst of an era of change. Frank, for instance, knew "the age of miracles was only dawning" and "felt himself in the grip of Titanic forces of nature sweeping through time and eternity." ${ }^{, 767}$ The problems of the modern city, including "the swiftness of progress, crushing and enriching, the mad greed for gold, the worship of success - a success that sneers at duty, honor, love, and patriotism... the growth of despair, the triumph of brute force," and "the reign of the liar and the huckster," needed to be addressed in order for the country to progress. ${ }^{768}$ The path to solving modernity's ills, however, was undecided. Dixon constructed two opposing interpretations of progress in characters' conversations. One was conservative. It assumed that tradition played a crucial role in advancement, placed individual freedom and private property at the heart of American civilization, and relied on "careful legislation" to solve these issues. ${ }^{769}$ The other stance favored a socialist revolution to remedy urban problems and usher in a period of peace and prosperity.

\footnotetext{
${ }^{765}$ Dixon, The One Woman, 136.

${ }^{766}$ Ibid, 207-08.

${ }^{767}$ Ibid, 42-43.

${ }^{768}$ Ibid, 71.

${ }^{769}$ Ibid, 236.
} 
Frank Gordon epitomizes the latter position. He believes "greed, commercialism, competition, and the monopolistic instinct" perpetuated modern society's problems. Frank proposed the time to alleviate "all this crime and misery and confusion" plaguing society had arrived, for "the very foundation of morals are shifting, and that Religion, Society, and Civilization must adjust themselves or humanity sink into unspeakable degradation." 770 By "leading a revolution that should decree a new basis for the Moral Law itself," Frank hoped to create an atmosphere where "love, not force, must rule the world." ${ }^{\text {771 }}$ Frank viewed the elimination of lifelong marriage commitments as a necessary step toward socialist progress, arguing love could "only be a reality in Freedom and Fellowship," not when it is "bound by chains" and "forever throttled by the mistakes of youth." 772 He sought to "proclaim the end of slave marriage and the dawn of perfect love" by making women equal partners in a new type of marriage "that shall give scope for our highest development." ${ }^{, 73}$ In Frank's logic, individual freedom is expanded under this new marital system where "each shall be free to find and love his own, love be loosed from tragedy... each life be its own, original and masterful.",774

Dixon introduced two oppositional voices to challenge Frank's definition of progress and ask questions about the consequences of his proposed socialist reforms. Through the characters of Mark Overman and William Gordon, Frank's father, Dixon

\footnotetext{
${ }^{770}$ Dixon, The One Woman, 103-104; 106.

${ }^{771}$ Ibid, 157-158; 103-104.

${ }^{772}$ Ibid, 185-86, 167.

${ }^{773}$ Ibid, 207-08, 162.

${ }^{774}$ Ibid, 167.
} 
explains three different ways socialism threatened to ruin America's future: the political triumph of socialism would "destroy the monogamic family," lead to widespread "mental and moral breakdown," and could not solve the economic problems facing the country. ${ }^{775}$ Each of these three points reflects different aspects of the way Dixon interprets the relationship between nationalism, civilization, society, progress, individualism, and marriage. Dixon viewed traditional Christian Protestant family structure as "the unit of society," "the basis of all law, state, national, and international... the basis of civilization itself," and the "source of all monopolistic instincts." 776 The character of William Gordon serves as Dixon's advocate of traditional Christian marriage. Lifelong marriage, as presented by William, "is a divine social ordinance on which the structure of human civilization has been reared.",777 "It is the law of the Lord," the elderly man insists, "and the law of the Lord is perfect.","78 Marriage vows were unbreakable "without two people's consent and the consent of society, and then only for great causes which have destroyed its meaning." ${ }^{, 779}$ Destroying traditional marriage, William warns, is not "progress," but "to return to the beast of the field." ${ }^{.780}$ Dixon asserts the incompatibility of socialist goals and traditional marriage throughout the narrative.

\footnotetext{
${ }^{775}$ Dixon, The One Woman, 32, 35, 243-244.

${ }^{776}$ Ibid, 193-194, 35-36.

${ }^{777}$ Ibid, 196.

${ }^{778}$ Ibid, 193-194.

${ }^{779}$ Ibid, 196.

${ }^{780}$ Ibid, 193-194.
} 
As the primary anti-socialist character in the novel, as well as the symbolic opposite of Frank, Mark Overman's dialogues also demonstrate the prevalence of gendered themes in several of Dixon's anti-socialism arguments. One of Mark's primary points is that socialist ideology directly opposed the continuance of traditional marriage. Most people with socialist political leanings, Mark argues, lacked an understanding of its ideological foundations. They did not "know the origin or meaning of this Socialistic dream." 781 Dixon uses a conversation between Mark and Frank to incorporate selections from early socialist thinkers, such as Charles Fourier, William Morris, and Robert Owen, with the goal of proving the doctrine's inherent incompatibility with traditional marriage. Fourier, Mark Overman maintains, interpreted monogamy and private property as "the main characteristics of civilization... the breastworks behind which the army of the rich crouch and from which they sally to rob the poor." ${ }^{, 782}$ Mark insists that traditional family and monogamous marriage are closely linked to the concept of private property. They were part of the core framework early socialists sought to overturn, since "the herd and the mating pair cannot coexist as dominant forces.",783 "Robert Owen," according to Mark, envisioned a "new Moral World" where "the irrational names of husband, wife, parent, and child will be heard no more. Children will undoubtedly be the property of the whole community.", ${ }^{174}$ Since "woman's maternal instinct created monogamic marriage," Mark tells Frank, females were biologically programmed to oppose socialism's threat to

\footnotetext{
${ }^{781}$ Dixon, The One Woman, 38.

${ }^{782}$ Ibid, 35-36.

${ }^{783}$ Ibid, 38.

${ }^{784}$ Ibid, 35-36.
} 
traditional family structures. "Socialism never converts a woman except through some individual man," in Mark's point of view, and "the only women who become Socialists directly are the sexless, defectives, and the oversexed." ${ }^{785}$

Much of The One Woman's latter half explores the importance of a societal balance between civilized social constructions and the barbaric tendencies of individual human nature. Traditional gender roles were seminal themes in Mark Overman's alternative view of progress. In his conversations with Frank, Mark places individual manhood at the middle of his conception of progress. The influence of Demolins' work on Dixon appears plainly in Mark's statements. Anglo-Saxons “developed the most powerful individual man in history," Mark argues, "while the other races have sought refuge in the herd ideal of communal interests." ${ }^{.786}$ Socialism's threat to individual manhood represents the opposite of progress to Mark. Instead, the "maggot of Socialism" destroyed individual character, making men "flabby" by sapping men's will, brain, religion, and moral fiber. ${ }^{787} \mathrm{He}$ viewed socialism as "a stampede back to the animal herd out of which a powerful manhood has evolved," "not a prophecy of progress," but "a memory of the dirt out of which humanity has slowly grown.",788 Socialism meant a return to a pre-civilized state barbarism, he argued, which, of course, was not progress at all.

\footnotetext{
${ }^{785}$ Dixon, The One Woman, 38.

${ }^{786}$ Ibid, 248.

${ }^{787}$ Ibid, 32-33.

${ }^{788}$ Ibid, 32-33, 236.
} 
In the second novel, Comrades, Dixon continued exploring the ways in which socialism, as a doctrine, was flawed and overly simplistic. Dixon demonstrated this point using the story of a failed utopian colony to illustrate the complexities of socialist theory put into practice. His main argument in this work is that a socialist government would not solve the problems of capitalist society; it would replicate them with a poorer quality of life for the people within its borders. As the narrative unfolds in the Ventura colony, its leadership is faced with the same questions and vulnerability to corrupt leadership as the society they were trying to escape. The process of eliminating inequality and a productive workforce while maintaining individual freedom of choice proved one of the most problematic. Near the book's end, Dixon deemed "the power to assign and enforce work... the mightiest force ever developed in the hand of man."789 Paying higher wages for undesirable work prevented the need for forced labor, but also ran the risk of creating "a new aristocracy on whose shield is emblazoned - a dishrag and a scrubbing brush.,"790 Yet without laborers for the unwanted positions the colony could not prosper, and to for the government to force them to do so violated the very liberty and freedom at the movement's core. At the heart of this issue was the creation of wealth: What gave an industry or product its worth, the inventors and owners of the endeavor, or the hours of labor performed by workers? ${ }^{791}$ The components of "liberty" and "equality," and how to protect them formed essential parts of Dixon's critique. These questions increased in

\footnotetext{
${ }^{789}$ Dixon, Comrades, 306-307.

${ }^{790}$ Ibid, 162.

${ }^{791}$ Ibid, 229.
} 
number and complexity as the colony's population grew and faced the problem of strong opposition in more significant numbers.

Like the previous novels, many of his many arguments and themes are found within the characters and plot details. The work's main character, Norman Worth, "an amateur socialist" served as the reader's guide to understanding socialism's appeal and comprehending its ultimate problems. In many ways, it is a story of his ideological development. Idealistic, dedicated, and well-intentioned Norman joined the Socialist Club after attending one of their meetings. Expecting "a throng of low-browed brutes," Norman found instead that the diverse crowd "was distinctly an intellectual one... certainly not fools... and to his amazement he noticed a lot of men he knew in the crowd. ${ }^{.792}$ He began spending time with another member, Barbara Bozenta, who strengthened his anti-capitalist sentiments by visiting "the four greatest institutions of modern civilization," the "poorhouse," hospital, jail, and the morgue. "With each new glimpse of the underworld of pain and despair," Norman's determination to change the current situation of his hometown increased. ${ }^{793}$ He dedicated his time to the socialist cause and quickly gained a reputation at the Socialist Club as a leading activist.

Once his utopian experiment was in place, however, Norman started questioning the wisdom of socialism. Though "he had condemned the sins of the old world of capitalism with cocksure certainty," the "new problems which arose at every step of progress in the new moral world" left him "appalled at the magnitude of the task of substituting [for the accepted] ideal of the reign of natural law under which civilization

792 Dixon, Comrades, 19-20.

${ }^{793}$ Ibid, 42. 
had slowly evolved." ${ }^{, 794}$ Deteriorating social conditions in the colony convinced Norman of the need to "use the power of law with more stern, direct, and personal pressure than ever known under the system of capitalism, or we must fail," though he hoped the community would "outgrow" such measures. ${ }^{795}$ Only after Norman's power is usurped does he "realize the meaning of the work he had been doing, and began to see how deftly and unconsciously he had been forging the chains of a system of irresponsible slavery on his fellow men."

Dixon uses the characters of Hermann Wolf, his wife Catherine, and the Socialist Club member Barbara Bozenta to demonstrate how the socialist ideal is vulnerable to political corruption and that its eventual end would be communism. All three of the villains in Comrades are socialist activists. This trio acts as manipulators throughout the tale, even though Barbara has a change of heart at the end by helping Norman. The main antagonist in this tale is Herman Wolf, "the famous 'blond beast' of Socialism" and leader in the movement. ${ }^{797}$ He is a "man of wide reading an deep convictions." Wolf"s "affinity wife," Catherine, widely known as the "Scarlet Nun," was a key leader in the socialist movement. She had led two workers' strikes in New York and twice served jail

\footnotetext{
${ }^{794}$ Dixon, Comrades, 166.

${ }^{795}$ Ibid, 206.

${ }^{796}$ Ibid, 259.

${ }^{797}$ Dixon was likely using the term "blond beast" in reference to Friedrich Nietzsche's On the Genealogy of Morality: A Polemic (New York: Boni and Liveright, 1887. First introduced in the First Treatise of this work, Nietzche's concept of the "blond beast," often symbolically linked to the lion, argued against viewing beasts of prey as 'evil' because their actions were driven by nature, not by malicious intent. For more on American interpretations of Nietzsche, see Jennifer Ratner-Rosenhagan, American Nietzsche: A History of an Icon and His Ideas (Chicago: University of Chicago Press, 2012).
} 
sentences for exciting riots. ${ }^{798}$ The third key person in this web, Barbara Bozenta, was the up-and-coming leader in the Socialist Club of California. Born in "the little Socialist colony of Polish dreamers led by Madame Modjeska, Count Bozenta, and Henry Sienkiewicz," and later taken by to Poland after the settlement's failure, Barbara had been raised in the socialist tradition. ${ }^{799}$ She and the Wolfs purposefully decided to use their influence over Norman, the Wolfs as mentors and Barbara as a love interest, in order to eventually take full control over the island. Once in power, though, Herman Wolf decides to install a communist government.

Colonel Worth, Norman's father, serves as the counterbalance to the Wolfs and Barbara. As a character of the Colonel represents traditional American masculine nationalism, as Dixon would have defined it in 1909. The Colonel shared many of Dixon's own post-Spanish American War patriotic beliefs. For instance, Colonel Worth interpreted the American flag as "the proud emblem of human freedom and human progress," believing that war served a "the searchlight of history, the great revealer in national life of hidden strength and unexpected weakness." ${ }^{, 800}$ The Colonel also shared with the author a belief that the Spanish-American War ended sectionalism, creating "the

\footnotetext{
${ }^{798}$ Dixon, Comrades, $11 ; 50-51$.

${ }^{799}$ Ibid, 29-30; The community Dixon is referring to did exist. The small utopian project was established in 1876, in Anaheim, California, by Polish actress Helena Modjeska (Modrzejewska) and her husband Count Karol Bożenta Chłapowski. Polish novelist and journalist, Henryk Sienkiewicz, accompanied them. Sienkiewicz is best-known produced a trilogy of historical novels set in the seventeenth century PolishLithuanian Commonwealth. It is possible Dixon modeled the structure of his own Reconstruction Trilogy after the work of Sienkiewicz (Cook, Fire From the Flint, 105). For more on these three figures and their settlement, see: Beth Holmgren, Starring Madame Modjeska: On Tour in Poland and America (Indianapolis: Indiana University Press, 2012); James Patrick Barron, "The American Reception of Henryk Sienkiewicz's Quo Vadis?" Ph.D. Dissertation, University of Chicago (2005); and Arthur Prudden Coleman, Wanderers Twain: Modjeska and Sienkiewicz: A View from California (Cheshire, Connecticut: Cherry Hill Books, 1964).

${ }^{800}$ Dixon, Comrades, 5-6.
} 
Union our fathers dreamed... We are one people — one out of many." ${ }^{801}$ Further, Colonel Worth believed that socialism was un-American, both in applicability and in origin, "a contagious disease, imported from the old world... its reasons for existence in this country are purely imaginary." ${ }^{\prime 02}$ The Polish origins and heritage of two of the three main characters reinforces this negative association. The Colonel fears socialism's impact on individuality, arguing "character is the one thing the scheme of Socialism leaves out... the one thing a machine made society could never produce." ${ }^{, 803}$ Indeed, he only funds Norman's experiment because he appreciates his son's newfound enthusiasm and dedication.

The power of media represents a strong thematic continuity between Comrades and Dixon's previous work. In this case, communication is both a positive and negative entity for Norman. In the beginning of the work, the socialist movement effectively uses the power of newspapers to gain followers and advertise its new utopian colony. Norman and Herman Wolf, though, tied newspapers to corruption and civic disorder and "cut every line of possible communication with modern competitive society" (except by special permission). ${ }^{804}$ Though designed to prevent corruption and hinder criticism from the papers, Ventura's isolation prevented its citizens from asking the outside world for assistance. New groups of colonists arrived with no word of the colony's deteriorating

\footnotetext{
${ }^{801}$ Dixon, Comrades, 7-8.

${ }^{802}$ Ibid, 101-102.

${ }^{803}$ Ibid, 36.

${ }^{804}$ Ibid, 115-117.
} 
conditions. Communication saves the day at the tale's end, however, as Barbara sent a telegram for assistance.

Dixon's third novel in this trilogy, The Root of Evil, explored the socio-economic results of the "new era of combination, merger, and cooperation." 805 To Dixon, corporatism was a form of cooperative socialism designed to exploit the average citizen, corrupt the government, and undermine Christian morality, and it had drastically reshaped American life. Throughout The Root of Evil, Dixon uses the narrative and characters to demonstrate that "the age of materialism had dawned, and the new age knew but one God, whose temple was the marketplace." 806 For the author, the "modern craze for money at all hazards, by fair or foul means" impacted every walk of life by upending the previous system of determining social status and worth. In Dixon's turn-ofthe-century New York, materialism replaced the aristocratic and moral codes of society's previous class structures and moral codes with one based solely on wealth. Men and women adopted new definitions of "success," which prized wealth and compelled people to "marry in cold blood, calculating with accuracy their bank accounts." 807 The exploitative labor practices of corporations simultaneously exacerbated the importance of wealth and highlighted the cost of increasing profits. Dixon set his story against this backdrop of changing social norms, uses it to question corporate theories of "progress.",808

\footnotetext{
${ }^{805}$ Dixon, The Root of Evil, 50-51.

${ }^{806}$ Ibid, 194.

${ }^{807}$ Ibid, 61-62; 106-107.

${ }^{808}$ Ibid, 18.
} 
Another prominent message in The Root of Evil is the danger of government corruption and the loss of individual liberty in a world where wealth equaled power. Dixon worried this new trend in American life provided a foundation for building "a castle exactly like the one from which the tyrants drove him in the Old World." ${ }^{\prime 09}$ Dixon's New York in this book had become a "Kingdom," in the process of complete with a "King" of Wall Street, his many corporate "masters," and laboring "slaves." And within this Kingdom, "modern business is war, the fiercest and most cruel the world has ever known." 810 In this "Kingdom of Mammon in America," a "system of fraud and chicanery had spread from the heads of the big companies until the whole business world was honeycombed with its corruption." 811 "A new set of corrupt lawmakers took the place of the old ones, their palms always itching for money," which demanded potential politicians “must grease their itching palms or make way for those who will." Dixon's portrayed corruption empowering the wealthy, as government structures protected corporate trusts as mechanisms of "progress," "economy," and "efficiency." Using "tricks and subterfuge in the form of a printed paper called stocks," financiers legally coined "money out of nothing by binding the burden of debt onto the backs of helpless millions." Worse, the "organizers of modern industry" ruined the economy by closing mills instead of opening them, cutting jobs, harming producers by lowering their bids for raw materials, and raising the prices of consumer goods. ${ }^{812}$

\footnotetext{
${ }^{809}$ Dixon, The Root of Evil, 368-369.

${ }^{810}$ Ibid, 136-137; 204-205; 256.

${ }^{811}$ Ibid, $62,133$.

${ }^{812}$ Ibid, $11-12 ; 51-52$.
} 
In addition, Dixon returned to the theme of the animal within human nature and argued for a traditional socio-economic value system in order to limit widespread chaos. The "virtues" of the old aristocracy, "the grace, elegance, breeding, and culture of the past" did not apply as "binding laws on the new masters of the world." In this tale, corruption and economic instability in the modern age displaced man's "faith in one another... the sustaining force of all personal and social life," triggering "a lapse to the level of the beast of the field whose life is ruled by fear." ${ }^{\prime 813}$ The result is a return to beast-like behavior. Each of the main characters, either because of jealousy, rage, frustration, or greed, fights to suppress their inner beast. James' "savage impulse" to strangle Bivens, for instance, came from "throbbing forces of savage cruelty that... had given his ancestors the leadership of men before the finer virtues of love and mercy." Other examples appeared in Woodman's attempt to seek revenge on Bivens after their argument left the doctor with a "new sense of brutal power" and Nan's homicidal behavior. ${ }^{814}$

Through the intertwining stories of the characters, Dixon illustrated the different ways the new system upended traditional gender norms and class hierarchies. The main male character, James Stuart, represents the coming-of-age generation of men. Dixon imparted some of his own biographical details onto James, such as his North Carolina origins, training as a lawyer, and a failed excursion in politics. Readers follow his life over the course of several years, as James wrestled with the end of his engagement and decided how to succeed in the modern world. In the process, James explored his

\footnotetext{
${ }^{813}$ Dixon, The Root of Evil, 258; 178-180.

${ }^{814}$ Ibid, 236; 280.
} 
opinions about wealth and how to define "progress" and "success." At the beginning of the story, he still adheres to the pre-1900 value systems and tried to adhere to them. After hearing of Bivens' initial job offer, for instance, James tells Nan he cannot "prostitute my talents to a work I do not believe in... degrade myself with a work I hate, or take orders from my I despise. The world is already full of such slaves." ${ }^{\prime 815}$ After Nan marries Bivens and Woodman's court case ended, though, he began "to see now that the world's battles are no longer fought with gun and sword," and accepted the lucrative job. ${ }^{816}$ The extent of corruption James discovered after befriending Bivens led him to question "whether this is the Republic for which our struggling fathers fought and died?" ${ }^{817}$ After learning Nan played a role in Bivens' death, James ultimately concluded to reject her as a partner, along with the urban, material life. He settled into a quiet, rural life with Harriet Woodman, his neighbor's daughter.

The figure of James' neighbor, Dr. Henry Woodman, represented the dying generation of men and their ideals. Dixon portrays Woodman as a member of the doomed "old regime of the small manufacturer and the retailer," the sort of man rapidly disappearing as "combination" became "the new order of life." $" 818$ He doted on his daughter, Harriet. As a businessman, Woodman operates in a manner that gives back to him community by running the "Life Line," a free service providing medicine and medical advice to those too poor to see a doctor. He is an integral part of his community,

\footnotetext{
${ }^{815}$ Dixon, The Root of Evil, 26-27.

${ }^{816}$ Ibid, 220.

${ }^{817}$ Ibid, 368-369.

${ }^{818}$ Ibid, 18.
} 
and the business of pharmaceuticals, and sticks to his morals. Woodman believed in the individual liberty, and refused to participate in transforming "the Republic into a huge money stamping machine and turn its freemen into slaves. ${ }^{819,}$ In order to alleviate the suffering of laboring men, the country needed "leaders whose voice shall rouse the conscience of the nation that Justice shall be done." ${ }^{820}$

In exact opposition to Woodman is the character of John C. Calhoun Bivens, which represented the new standard of success. ${ }^{821}$ Bivens came from "the veriest trash" of North Carolina and attended college with James, before accumulating massive wealth as "The Weasel" of Wall Street. ${ }^{822}$ Dixon used Bivens' poor background, exploitative business practices, and recent position of power and an example of the "the coming reign of the huckster." ${ }^{823}$ It turned out, though, that Bivens was a very complicated and intelligent character that acts as both villain and warning. His "whole makeup, physical and mental, was curiously complex - a mixture of sobriety and greed, piety and cruelty, tenderness and indomitable will." As an "expert thief" but a devout member of the church and adhered to the written laws of society, Bivens underscores the seeming contradictions in corporatist economy. Throughout the body of the work, he is a self-

${ }^{819}$ Dixon, The Root of Evil, 53-54.

${ }^{820}$ Ibid, 18.

${ }^{821}$ His namesake is John Caldwell Calhoun (1782-1850), South Carolinian statesmen known for defending slavery and the concept of minority rights. This is a wonderful connection between the constitutional conservatism of the Reconstruction Trilogy and the individualism inherent in Dixon's second trilogy of novels. Analyzing the particulars of this connection exceeds the parameters of this dissertation (each of the books could get its own chapter), but Dixon's choice is rich in symbolism for this period. Calhoun was a critical figure in the Dunning-style narrative of Reconstruction history. See: Thomas J. Brown, "The Monumental Legacy of Calhoun," in Fahs and Waugh, eds. The Memory of the Civil War (2004), 130-156.

${ }^{822}$ Dixon, The Root of Evil, 35 .

${ }^{823}$ Ibid, 212. 
proclaimed "product of the age - no better, no worse than the principles of modern society." ${ }^{\prime 82}$ Dixon used James and Bivens' friendship to highlight the cutthroat nature of corporate business in New York, where "a man who can't be bought and sold" proved to be "the thing beyond price." 825 Bivens freely admitted to the power of wealth, and predicted "the coming billionaire" of corporatism would "know no limitations on power." ${ }^{826}$ Through Bivens, Dixon also offers a message of hope and warning to its reader. Bivens' health is the one thing money cannot buy, and it is only after his stroke that he realizes the faults of his greedy actions. ${ }^{827}$

Dixon paid particular attention to the changes in gender norms brought on by corporate capitalism. Nan Primrose, Bivens' wife and James' ex-fiancé represented Bivens' female counterpart, the new type of woman who values money above all else. Nan expected a certain type of lifestyle, one in accordance with the modern era where money equaled "the badge of success, the symbol of power." ${ }^{" 828}$ She viewed marriage as her "only career" where a "mistake now would be fatal" to her larger "desire for power." Nan carefully calculated her every decision in the book as part of her quest for wealth and social power, refusing to deem her wants "vulgar avarice" when businessmen of the same mindset were labeled "high ambition." Dixon employed Nan as a woman lacking the previous moral assumption that "the career of any woman was immeasurably grander

\footnotetext{
${ }^{824}$ Dixon, The Root of Evil, 35-358; and 355.

${ }^{825}$ Ibid, 138.

${ }^{826}$ Ibid, 204-206.

${ }^{827}$ Ibid, 397-398.

${ }^{828}$ Ibid, 28.
} 
than that of any man - if she fulfill her destiny that links her to God in the creation of a child. She is every bit the scheming competitor, all the way up to the murder of Bivens. ${ }^{829}$ The alternate love interest for James, the doctor's daughter Harriet, stood for Dixon's ideal woman. In stark contrast to Nan, Harriet's ideal man is not wealthy but "strong" with "a big, noble ideal of life," since she only desired a "little home nest, and a baby, for the love of one man." Everything Harriet pursues, she does "only to please her hero that is, or is to be. ${ }^{830}$ In the end, Harriet won James over and they moved into a small North Carolina cottage.

${ }^{829}$ Dixon, The Root of Evil, 74; 85.

${ }^{830}$ Ibid, $10 ; 363$. 


\section{$\underline{\text { Chapter Six }}$}

\section{$\underline{\text { Responses to Dixon's Work (1905-1946) }}$}

During the first two decades of the twentieth century, even as he published the Anti-Socialist Trilogy, Dixon increased his public animus toward racial equality. From 1902-1920, he made regular contributions to the ongoing debate about the definition of citizenship, and produced some of the most virulent public endorsements of white supremacism of his career. Stage adaptations of the Reconstruction Trilogy and its 1915 film version, The Birth of a Nation, cemented Dixon's public image with white Southern racism during these years, as his controversial works spread across the country and then the world. The response to his work, as well as his public involvement in national debates, demonstrates the many competing thoughts on matters of race, citizenship, and sectionalism, as well as the complex reciprocity between individual historical actors and their times. This chapter explores three topics: the Reconstruction Trilogy's transition from print to stage (and later film), the various reactions to Dixon's work, and his public justification for his ideals.

In some ways, Dixon succeeded in the goal of publicizing his intended messages in his first two book trilogies. All six novels sold well, appearing on "Top Six Bestselling New Books" Lists throughout the country. The Reconstruction Trilogy achieved significant popularity in the early years of the twentieth century. It sold remarkably well, and brought Dixon's ideas to Europe and Asia. The Leopard's Spots' first printing in early 1902 of 15,000 copies sold out quickly, and the book reached 
23,000 sold copies within two weeks of publication. ${ }^{831}$ By July of 1904, 200,000 copies had been sold and the novel translated into German. ${ }^{832}$ The Clansman, published in 1905, also sold well. Its first edition of 40,000 copies sold out in ten days. ${ }^{833}$ It eventually equaled the impressive sales numbers of its predecessor and was translated into German and Japanese. ${ }^{834}$ The last installation in Dixon's Reconstruction Trilogy, The Traitor (1907 confirmed this trend. It debuted on several cities' "top six" lists of popular new books, including Baltimore, Birmingham, Buffalo, Chicago, Cincinnati, Dallas, Detroit, Kansas City, Milwaukee, Minneapolis, New Haven, Providence, Seattle, and San Francisco. ${ }^{835}$ Dixon's Anti-Socialist Trilogy sold equally well. The most popular novel of the series, The One Woman (1903), appeared in the number one spot on "Bestselling New Books" lists in Atlanta, Cleveland, Dallas, Memphis, Kansas City (Missouri), New Orleans, and Toledo. ${ }^{836}$ The second and third installations, Comrades (1909) and the Root of Evil (1911) also attracted significant readership. They showed up frequently on bestsellers' lists from all over the country, including Norfolk, New York

\footnotetext{
831 "Display Ad 23: The Leopard's Spots," New York Times, March 8, 1902; "Literary Notes," The Baltimore Sun, April 10, 1902;

832 "Display Ad 20: The Leopard's Spots," New York Times, May 2, 1903; “The Leopard's Spots," New York Times, July 25, 1903; "Publication Notes," The Atlanta Constitution, May 8, 1904.

833 "Books that Sell Well," New York Times, February 4, 1905.

834 “The Clansman in Japanese," The Washington Post, August 27, 1905.

835 "Sales of the Books During the Month," in The Bookman: An Illustrated Magazine of Literature and Life, volume 26 September 1907-February 1908 (New York: Dodd, Mead and Company, 1907), 220-224.

836“'Sales of the Books During the Month," in The Bookman: An Illustrated Magazine of Literature and Life, volume 18 September 1903-February 1904 (New York: Dodd, Mead and Company, 1903), 222-224, 333-338.
} 
City, Portland (Oregon), Seattle, Omaha, Chicago, Cincinnati, Birmingham, and New Orleans. ${ }^{837}$

From 1905 to 1920, Dixon attempted to adapt the Reconstruction Trilogy and the Anti-Socialist Trilogy to the stage or film, and sometimes both. He believed "the drama is the great force which, within the next few years, will sway the thought and destiny of the nation," and prophesized "that one hundred years from now the men who will sway the country will be those who can express themselves in this form." ${ }^{838}$ His initial adaptation of the Reconstruction Trilogy to the stage combined elements of the first two novels into one continuous, but shorter, narrative. Titled The Clansman, it appeared on stage in mid-1905 and actively toured the nation over a five-year period, which included performances in New York, Virginia, Maryland, Illinois, Georgia, California, and the Carolinas. ${ }^{839}$ On occasion, Dixon himself played the leading role. Showings were accompanied by pamphlets of Dixon's essays on race. The publication presented the play as a sequel to Stowe's Uncle Tom's Cabin and printed three of his articles on the subject of Reconstruction. ${ }^{840}$ "I seek national unity through knowledge of the truth," he argued

837 "Sales of the Books During the Month," in The Bookman: An Illustrated Magazine of Literature and Life, volume 29 March-August 1909 (New York: Dodd, Mead and Company, 1909), 109-113; 211-223; 325-339; and "Sales of the Books During the Month," in The Bookman: An Illustrated Magazine of Literature and Life, volume 33 March-August 1911 (New York: Dodd, Mead and Company, 1911), 106$112 ; 212-224 ; 330-340 ; 440-449$.

838 “Drama Will Sway Nation's Destiny,” The Atlanta Constitution, November 19, 1910.

839 "Plays and Players," The Sun (Baltimore), April 16, 1905; "Stage Notes," The Washington Post, July 23, 1905; "Dixon With Play in Danville," The Sun (Baltimore), October 1, 1905; "Plays and Players," The Sun (Baltimore), December 24, 1905; "Playbills," Chicago Daily Tribune, June 17, 1906; "Music and the Stage," Los Angeles Times, December 1, 1908; "Leopard's Spots Friday Night," Western Carolina Democrat and French Broad Hustler (Hendersonville, North Carolina), October 30, 1913.

${ }^{840}$ Thomas Dixon, The Clansman: An American Drama From His Two Famous Novels The Leopard's Spots and The Clansman, Presented By the Southern Amusement Co. (New York: American News Co., 1905), 16 . 
in the introductory piece and, "the historical accuracy of this picture is absolutely unassailable." ${ }^{841}$ He advertised the play as "an American drama," rather than framing it as something solely of regional interest. ${ }^{842}$

The 1905 play marked the first stage adaptation of many. The Leopard's Spots eventually appeared as its own stage event. It differed from The Clansman, Dixon argued, by taking a "wider scope, dealing not only with the incident immediately following the war but with events occurring through the intervening years down to the present day. ${ }^{1843} \mathrm{He}$ also converted The Traitor and The One Woman into plays. ${ }^{844}$ Though Dixon eventually adapted the Anti-Socialism novels to the stage, the second trilogy as a whole never maintained a significant popular following. Literary critics and theatrical publications commented on the trilogy and pro-socialist groups denounced the books, plays, and (eventually) films, but the general public paid the Anti-Socialist Trilogy little critical attention. ${ }^{845}$ Though Dixon did not focus on the Anti-Socialist

\footnotetext{
${ }^{841}$ Thomas Dixon, The Clansman: An American Drama From His Two Famous Novels The Leopard's Spots and The Clansman, Presented By the Southern Amusement Co. (New York: American News Co., 1905), 16.

${ }^{842}$ Ibid.

843 “Leopard's Spots Friday Night," Western Carolina Democrat and French Broad Hustler (Hendersonville, North Carolina), October 30, 1913.

844 “Platt Signs a Contract with Rev. Thomas Dixon," The Atlanta Constitution, June 8, 1908.

${ }^{845}$ For a sample of reviews of the Anti-Socialist Trilogy from 1903-1915, see: "Thomas Dixon's Novel, 'The Traitor,' Offends Reviewer's Taste" It is Called Crude, Narrow, and Angry Minded, and Arouses Passions Which Should be Still," Chicago Daily Tribune, August 10, 1907; "Fiction: The One Woman," The Sun (Baltimore), August 6, 1903; "Brief Notices of New Books, 'The Root of Evil'," New York Times, February 11, 1911; "Book Reviews," The International Socialist Review 4 (1903-04): 379-380; "Fresh Literature, New Books Reviewed: Fictional Preachment," LA Times, February 14, 1909; and T.S.

Dunaway, "Dr. Dunaway Pleased With Dixon's New Book," The Free Lance (Fredericksburg, VA), March 13, 1911.
} 
Trilogy in the years from 1903-1915, he eventually adapted The One Woman and Comrades (retitled Bolshevism on Trial) to screenplays in 1918 and 1919.

Dixon's decision to concentrate primarily on the Reconstruction Trilogy from 1900 to 1915 mirrors the prominence of race in the period's political and cultural debates. In addition to segregation, lynching, and disfranchisement, continuing violence exacerbated racial tensions, as demonstrated by the 1906 race riot in Atlanta. The Atlanta race riot was one of several in the early-twentieth century. It began after a series of newspaper reports claiming African American men had sexually assaulted white women, and thousands of enraged white men attacked Atlanta's black communities in retaliation. ${ }^{846}$ The resulting three-day long clash between racially divided armed groups led to the deaths of twelve people, ten black and two white, and it reverberated throughout the nation. The newspaper reports preceding the riot reinforced AngloSaxonist narratives about the "dangers" of equality, and fueled white concerns about the increasing possibility of a race war. The brutality of the attacking white mob, meanwhile, aroused African Americans' fear of racial genocide and provoked a dispute about the wisdom of racial violence. ${ }^{847}$

The variety of responses to Dixon's Reconstruction Trilogy underscores the complexities of debates about racial issues in the early-twentieth century. His Reconstruction novels and their stage iterations received mixed reviews, ranging from extreme praise to hatred. The trilogy was, as one critic put it, "furiously assailed both as

\footnotetext{
${ }^{846}$ David Fort Godshalk's Veiled Visions: The 1906 Atlanta Race Riot and the Reshaping of American Race Relations (Chapel Hill: University of North Carolina Press, 2005) provides a detailed examination of the 1906 race riot in Atlanta.

${ }^{847}$ Godshalk, Veiled Visions, 1-4.
} 
history and as art, and stoutly defended." ${ }^{, 848}$ Positive reviews of the trilogy hinged on the works' historical accuracy and the applicability of their message to American life. This trend began with the initial novel, The Leopard's Spots. Though "the plot is not especially strong," one review noted, "and its portrait of life is somewhat exaggerated... there is little doubt most of the incident in the book is taken from real life or the history of the times." ${ }^{849}$ This reviewer also found Dixon's writing effective in delivering its message, for "the reader finds himself absorbed in the 'lesson' to the exclusion of the hero and the heroine." 850 "The general tone" of the novel was "one of fairness, the mistakes made by both sides being unhesitatingly exposed."851 "It ought to be extensively read," concluded another reader. ${ }^{852}$

Other glowing endorsements of the Reconstruction novels were rooted in claims regarding the book's accuracy and the importance of the message. The second novel, according to one review, presented "with fair accuracy certain facts with reference to the most disastrous experiment ever made by American politicians - facts that no wellinformed Negro can deny and no intelligent Negro will see any reason for denying." ${ }^{853}$ A notice in The Washington Post maintained that The Clansman had "given to the North a

\footnotetext{
848 “Mr. Dixon's Latest Ku Klux Novel: 'The Traitor': A Grim, Absorbing Story by a Yellow Journalist Seeking Sensation, Not Truth," New York Times, August 3, 1907.

849 "Negro Since the War: 'The Leopard's Spots' Deals with Race Question," The Washington Post, March 30,1902 .

${ }^{850}$ Ibid.

${ }^{851}$ Ibid.

852 “Book Notices," The William and Mary Quarterly 10, no. 4 (April 1902): 283.

853 “Topics of the Times," New York Times, February 4, 1905.
} 
real idea of the white man's burden in the South." ${ }^{, 854}$ One reader argued that Dixon "is conducting for us a campaign of education which but few men have the nerve or hardihood to undertake. ${ }^{, 855}$ According to this reviewer, race war threatened the nation and "plans must be formulated for the ultimate settlement... [to] educate and gain the friendship and cooperation of our brethren in the North." ${ }^{, 86}$ In a letter to the editor of The Sun in Baltimore, a reader claimed Dixon's books needed to be read by “every person of the rising generation and every foreign voter... as well as others of a similar import, and they will readily understand one of the reasons why we desire to eliminate the negro vote from our electorate." ${ }^{857}$ Another review scolded Dixon for not citing the work of T.C. Craven, a surgeon at Fort Monroe who served as the medical attendant to prisoner Jefferson Davis, which provided the details for the shackling scene of Dr. Cameron in The Clansman. This reviewer, however, saw this as evidence “to prove Mr. Dixon's claim that his fiction is founded on fact." ${ }^{, 858}$

Critics of Dixon's Reconstruction novels based their criticism on two main claims: the books were historically incorrect and that they accentuated "the bitterness between the races." ${ }^{859}$ Several reviewers denounced the novels' portrayals of African

\footnotetext{
${ }^{854}$ I.F. Marcosson, "Dixon as an Author: The Man and His Work Make an Interesting Study," The Washington Post, January 29, 1905. Cameron in 'The Clansman' Compared With Dr. Craven's Report of the Ironing of Jefferson Davis," The Atlanta Constitution, May 21, 1905; "Topics of the Week," New York Times, March 11, 1905.

859 “Mr. Dixon's The Leopard's Spots, New York Times, April 5, 1902; "War of Races Idle Prophecy: Dr. Wilbur Thirkield, Formerly of Atlanta, Sharply Criticizes Dixon," The Atlanta Constitution, April 29, 1902.
} 
Americans and Southerners as biased extrapolations of historical truth. A piece in the Chicago Daily Tribune, for example, argued that Dixon's story erred on various points. Dixon "paints the Negro too black; He makes the Negroes worse than they actually were," the article maintained. The Southern-born reviewer also criticized Dixon's portrayal of upper class white Southerners; He missed "certain tolerance born of compassion and deep understanding" that "whites of the slave and land holding classes" possessed for African Americans. The second novel, according to this analysis, also neglected the "patient and affectionate fidelity exhibited by the slaves during the war." Another example maintained Dixon's “whole show is a disgrace to Southern manhood and womanhood." ${ }^{\prime 861}$ The idea that Southern whites needed segregation to maintain racial purity impugned "the virtue of its women and the pride of its men," the piece charged, which made Dixon a "traitor to the people of his race and the section of his birth." 862

Other criticisms of the novels aimed at Dixon's "sensationalist" style and worried the repercussions of his virulent anti-equality messages. One reviewer claimed the danger was "not recklessness of concrete facts," but the author's bias and desire for fame casting "false light... upon the facts...to make a sensation." 863 One critic in the Chicago Daily Tribune similarly judged The Traitor as lacking “serenity, dignity, or outlook” and

\footnotetext{
${ }^{860}$ Richard Weightman, "Hated Memories of Ku Klux Klan Revived in an Overdrawn Tale: Lurid Pictures and Fancy in Thomas Dixon's Story 'The Clansman' Criticised by a Southerner as Being Unfair and Inaccurate," Chicago Daily Tribune, April 14, 1905.

861 “Dr. Broughton Talks of Dixon: Tabernacle Pastor Makes Further Reply to Clansman's Author," The Atlanta Constitution, November 6, 1905.

${ }^{862}$ Ibid.

863 “Mr. Dixon's Latest Ku Klux Novel: 'The Traitor': A Grim, Absorbing Story by a Yellow Journalist Seeking Sensation, Not Truth," New York Times, August 3, 1907.
} 
offensive to "taste in every direction," with its narrative "distinctly calculated to arouse in the minds of the young people of the South a bitterness and hauteur which they were happier without." ${ }^{864}$ African American leaders denounced Dixon as a propagandist and black preachers in New York delivered sermons against this "evil genius" whose work "slanders the Negroes - the Negroes who fed the Southern armies and protected the Southern women in the war." "865 "Like a thief in the dark," one preacher warned, Dixon sought "to enter the homes of the Negroes and despoil them of their rights. ${ }^{, 866}$ If Dixon's "insane agitations of passion continue unchecked," another review foreshadowed, "it will be the ruin of the Negro and the disgrace of the whites..

Mixed reviews of the stage adaptation of the Reconstruction Trilogy further demonstrate the opposing views of Dixon's work. Many Southern audiences welcomed The Clansman and its message on the stage. More than two thousand people attended its 1905 premiere in Norfolk, including former Governor Aycock of North Carolina and current Governor Robert Glenn, along with "many members of the legislature and some judges. ${ }^{.868}$ The Atlanta Constitution gave the performance glowing reviews, claiming

\footnotetext{
864 “"Thomas Dixon's Novel, 'The Traitor,' Offends Reviewer's Taste” It is Called Crude, Narrow, and Angry Minded, and Arouses Passions Which Should be Still," Chicago Daily Tribune, August 10, 1907.

865 "Denounce Disfranchisement: Hisses Great Mention of Vardaman and Tillman at All-Night Mass Meeting of Negroes," Los Angeles Times, February 3, 1906; “A Dixon Pamphlet Stirs Negro Clergy, New York Times, December 18, 1905.

866 “A Dixon Pamphlet Stirs Negro Clergy, New York Times, December 18, 1905.

867 "Dr. Broughton Talks of Dixon: Tabernacle Pastor Makes Further Reply to Clansman's Author," The Atlanta Constitution, November 6, 1905.

868 “'The Clansman' Presented: Dixon's Play Pleases Large Audience at Norfolk," The Sun (Baltimore), September 13, 1905; "Premier of Clansman: Thomas Dixon's Dramatic Answer to 'Uncle Tom's Cabin' Scores Success," The Washington Post, September 23, 1905; “'The Clansman' Staged: Norfolk Audience Welcomes Play of Reconstruction Period," New York Times, September 23, 1905.
} 
Dixon fulfilled the public's demand "for a new dramatist who has something new and true to say, and who has the courage to say it." The reviewer predicted the play would "arouse new ambitions and stimulate the American playwright to cut loose from mossclad traditions. It will surely blaze the pathway for a new American drama that will be as virile and as powerful as the people among whom its will be born." ${ }^{" 869}$ The public in Atlanta welcomed it "as the most virile drama of recent years," breaking theater attendance records. ${ }^{870}$ In Dixon's home state of North Carolina, performances in Raleigh sold out in an hour. ${ }^{871}$ Stage performances of The Leopard's Spots and The Traitor also evoked positive responses throughout the South, where their tour routes were concentrated. Reviewers argued The Leopard's Spots on stage did "more than the novel," providing "a full realization of existing conditions and a stirring prophecy of the future of the Negro and his relations to the white race." ${ }^{872}$ The Traitor impressed audiences as well, "the verdict appeared unanimous" in Norfolk "that The Traitor was more powerful than The Clansman."

The stage performance of The Clansman received praise in other regions, as well. At its first production in New York City, a large audience attended and "applauded it

\footnotetext{
869 "The Clansman on the Stage," The Atlanta Constitution, October 26, 1905.

870 "The Clansman on the Stage," The Atlanta Constitution, October 26, 1905; "Atlanta Sees 'Clansman': Thomas Dixon's Play is Enthusiastically Received There,” The Sun (Baltimore), October 31, 1905.

871 John C. Inscoe, “'The Clansman' On Stage and Screen: North Carolina Reacts," The North Carolina Historical Review 64, no. 2 (April 1987): 144.

872 “The Leopard's Spots: A Play with Real Power," The Review (High Point, North Carolina), April 16, 1914.

873 “'The Traitor' A Success: Thomas Dixon's New Play Enthusiastically Received in Norfolk," The Sun (Baltimore), September 29, 1908.
} 
warmly." Dixon interpreted this reception as proof "that there is no North and no South but that we are one people." ${ }^{874}$ In Baltimore, The Clansman drew a large audience. A review in The Sun called The Clansman "a play that will move any audience North or South, if that audience have at least one scintilla of feeling for the helpless and oppressed and the least desire to m maintain unsullied the blood of the Aryan race." This same piece argued the play "is not an attack on the Negro... but it is an attack on the 'sentimentalists,' the wildcat educators who would strike the Negro a stunning blow with the clenched fist of knowledge." ${ }^{875}$ The message begged "for old time Southern chivalry that dared to look things squarely in the face and dared to do what a right thinking people should have done. ${ }^{\circledR 876}$ In Los Angeles, the play opened to an enthusiastic welcome from a small audience. ${ }^{877}$

The Reconstruction Trilogy's stage incarnations also provoked a myriad of negative responses, receiving more aggressive criticism than the print versions. "The theatre going public" in Macon, noted the paper, "has not taken such note of a play in many years... The play will be received here undoubtedly with great demonstration either for or against it." ${ }^{, 78}$ In Columbia, South Carolina, The Clansman evoked "boisterous

\footnotetext{
874 “'The Clansman’ Applauded: Thomas Dixon, Jr., Says This Shows Sectional Lines Are Gone," The Sun (Baltimore), January 9, 1906.

875 Ibid.

876 “'The Clansman' Thrills: Mr. Dixon's Play Arouses Large Audience at Academy,” The Sun (Baltimore), March 13, 1906.

877 “Music and the Stage,” Los Angeles Times, December 1, 1908.

878 “Anxious the See The Clansman: Great Interest at Macon Over the Play Next Saturday," The Atlanta Constitution, October 19, 1905.
} 
enthusiasm, mingled with hisses and groans" from its large, mostly white audience. ${ }^{879}$ In Annapolis, while two audiences largely applauded the play, African American attendees left the theatre in disgust midway through the performance. ${ }^{880}$ The stage versions of the trilogy were also viewed as a form of sensational propaganda. Dixon's plays were branded inflammatory, inaccurate works designed to further racial and sectional differences. The Colored Citizens' Protective League in New York City deemed The Clansman "detrimental to public morals, historically inaccurate, slanderous to the memory of the Union soldier and patriot, and vilifying the Negro." ${ }^{881}$ Black ministers denounced The Clansman from their pulpits, calling it "the inspiration of Satan himself." 882 Dixon was accused of disrupting the current trend of "the white and the black race coming into a more mutual understanding," with his efforts to incite race hatred, threatening "civilization with bloodshed." 883 The Women's Christian Temperance Union argued the performances were "calculated to arouse race hatred and incite the lawless element to deeds and violence." ${ }^{884}$ W.E. Gonzales, editor of The State newspapers in South Carolina, accused Dixon of conjuring a historically inaccurate tale

\footnotetext{
879 “At the Local Theaters," The Washington Post, March 6, 1906; "Columbia Hisses Dixon: 'Clansman' Audience in South Carolina Disapprove of Race Drama,” The Washington Post, October 16, 1905; "Dixon's Play Stirs Wrath of Columbia," The Atlanta Constitution, October 16, 1905.

880 “'Clansman' in Annapolis: Two Audiences Applaud the Play, Negroes Leave in Disgust," The Sun (Baltimore), April 15, 1906.

881 “Negroes War on Dixon,” New York Times, December 21, 1905.

882 "More Hot Shot for T. Dixon: One Colored Pastor Suggests a Life Term in Jail for the Author," New York Times, December 25, 1905.

883 Ibid.

${ }^{884}$ W.E. Gonzales, “South Carolina Editor Denies Charge Made by Thomas Dixon, Jr.,” New York Times, January 2, 1906.
} 
to go "after the money regardless of consequences, regardless of epithets, regardless of the scorn of thinking men and women., ${ }^{, 85}$ Papers in Savannah and Macon also ran articles condemning The Clansman. ${ }^{886}$

As Dixon's plays debuted across the nation, versions surfaced in Asia and Europe, where international reactions also varied from welcoming to cautious. While Dixon prepared to debut The Clansman on stage in Norfolk, a Japanese company simultaneously produced a theatrical version with almost parallel premiere dates in Tokyo. ${ }^{887}$ "The affinity between the Clansman of the South and the Samurai of the Satsuma," one reporter commented, could be found in Dixon's description of the organization's leadership, which resulted in Southerners developing "the courage of the lion, the cunning of the fox, and the deathless faith of religious enthusiasts." ${ }^{888}$ Arrangements were also made for staged performances in Germany and England at a future time. ${ }^{889}$ In England, as in the United States, there was "concern that it might ignite racial tensions among the British public, acting as a 'casus belli." $" 890$

Boycotts, protests, and bans of plays' performances became a common occurrence as Dixon's stage productions appeared across the United States. Protests and

\footnotetext{
${ }^{885}$ W.E. Gonzales, "South Carolina Editor Denies Charge Made by Thomas Dixon, Jr.," New York Times, January 2, 1906.

${ }^{886}$ Ibid.

887 “The Clansman in Japanese," The Washington Post, August 27, 1905.

${ }^{888}$ Ibid.

889 "The Clansman in Japanese," The Washington Post, August 27, 1905; “'The Clansman' Again: Drama of Reconstruction Days Coming to Academy," The Sun (Baltimore), March 29, 1908.

890 "Editorial Article 6," The Atlanta Constitution, November 22, 1905.
} 
demands to bar performances appeared in New York City, Washington, D.C., Philadelphia, Wilmington, North Carolina, Atlanta and Macon, Georgia, Decatur, Alabama, Richmond, Detroit, Los Angeles, and Suffolk, Maryland. "A mob of three thousand Negroes" marched on the theatre in Philadelphia where The Clansman appeared, resulting in the mayor ceasing future showings for fear that "it would stir race trouble. ${ }^{.891}$ Eventually, fifty police officers and additional wagons were needed to quell the protest. ${ }^{892}$ A group of pastors petitioned President Roosevelt to request his assistance in barring the play in Washington. ${ }^{893}$ "With the Atlanta horror yet fresh in the public mind," argued the petition, "its production on the stage is... perilous to the public peace and should be forbidden." ${ }^{894}$ One performance of The Clansman was "plunged into darkness and fire alarms sounded," creating a "stampede" as the thousand person audience attempted to escape. ${ }^{895}$ In Roanoke, Virginia, a billposter tacking up advertisements for Dixon's work received a beating from a group of African Americans. ${ }^{896}$ "The Negro Ku Klux Klan," as an anonymous note was signed, and gave

\footnotetext{
891 "Fight 'The Clansman' Here: Brooklyn Negroes Plan to Prevent the Presentation of the Play," New York Times, November 18, 1906; "Court Scores Dixon: Philadelphia Judge Comments Scathingly on "The Clansman,"” The Sun (Baltimore), October 26, 1906; "The Rights of Playwrights," Chicago Daily Tribune, October 27, 1906.

${ }^{892}$ Ibid.

893 “Would Stop 'The Clansman': Pastors Appeal to President to Prevent the Performance," The Washington Post, October 6, 1906.

894 “Wants 'Clansman' Barred: Minister Asks That It be Suppressed in Washington,” The Sun (Baltimore), October 4, 1906.

895 "Tried to Create Panic: Theatre was Plunged into Darkness and Fire Alarms Sounded, Clansman was Being Played," The Sun (Baltimore), April 21, 1907.

896 "Billposter Beaten By Negroes,” The Washington Post, September 28, 1906; "Negroes Beat Billposter: He Was Putting Up Pictures of Thomas Dixon, Jr.," The Sun (Baltimore), September 28, 1906.
} 
Dixon an ultimatum: cease productions of The Clansman at Liberty Theater or be lynched by New York City’s enraged African Americans. He promptly obtained a gun permit. ${ }^{897}$

Though Dixon's works received positive support in many locations, calls for censorship or boycotts were increasing in number. Pro-equality advocates continued attacking Dixon in meetings, speeches, books, magazines, and newspapers, for intensifying race hatred and propagating inaccurate, hateful versions of history and the character of African Americans. Literary responses appeared with alternative narratives to Dixon's version of Reconstruction history and racial equality ${ }^{898}$ By 1909 , in addition to protests and bans of the plays, some libraries pulled the Reconstruction Trilogy from their shelves. ${ }^{899}$ In the midst of Dixon's many critics, African American leader and activist Kelly Miller emerged as one of the most vocal. Kelly Miller labeled him a "frenzied apostle of an evil propaganda who would deprive the Negro of his rights by holding up the grotesque and repugnant side of his life with hideous portrayal., ${ }^{900}$ Miller

897 “Threat to Lynch Dixon: Author of 'The Clansman' Applies for a Pistol Permit,” New York Times, February 4, 1906.

${ }^{898}$ See, for example, Sutton Griggs' The Hindered Hand (1905), George B.D. Swayze's Yarb and Cretine: or Rising from Bonds (1906), and Emma Raynor's Handicapped Among the Free (1903). The Hindered Hand was a literary response to The Leopard's Spots, written by Griggs under commission of the National Baptist Convention. The novels of Emma Rayner and George B.H. Swayze portrayed Southern African American life in direct opposition to the characterizations found in Dixon's work. For more on Sutton Griggs' response to Dixon, see: Clare Eby, "Slouching Toward Beastliness: Richard Wright's Anatomy of Thomas Dixon," African American Review 35, no. 3 (Autumn 2001): 439-458; Hanna Wallinger, "Sutton E. Griggs Against Thomas Dixon's 'Vile Misrepresentations': The Hindered Hand and The Leopard's Spots," in Jim Crow, Literature, and the Legacy of Sutton E. Griggs, edited by Tess Chakkalakal and Kenneth W. Warren (Athens: University of Georgia Press, 2013);

899 “No Dixon Books in Library: Dr. Steiner Says ‘The Clansman’ Is Not Good Literature, The Sun (Baltimore), October 11, 1909.

900 "Fierce Attack Made on South: Names of Tillman, Vardaman, Dixon, and Hopkinson Smith Hissed," The Atlanta Constitution, February 3, 1906. 
denounced Dixon as a "shameless apostate priest of God... doing the work of the devil. With Satanic glee he stirs the fire of race wrath and inflames the evil passions of men."901 The war of words between these Miller and Dixon began in 1905, after the latter published "Booker T. Washington and the Negro," in the Saturday Evening Post. The article began with ostensible praised, but went on to condemn Washington's desire to improve the black race and accusing prominent black notables, such as Washington, DuBois, Charles Chesnutt and Kelly Miller (though he did not name him directly), with an ulterior motive: amalgamation. ${ }^{902}$ In this article, Dixon championed colonization in Liberia as solution to this threat of "racial Armageddon."903 Miller responded with an “Open Letter” refuting Dixon's arguments of black inferiority.

In the letter, Miller repudiated Social Darwinism as a legitimate theory, arguing that it was outdated, which also undermined Dixon's thesis of innate black inferiority. ${ }^{904}$ He argued civilization was "not an attribute of the color of skin, or curl of hair, or curve of lips," and so "there is no necessity for changing such physical peculiarities." 905 Miller interpreted black inferiority as the result of social oppression, which gave the race less

\footnotetext{
901 "Fierce Attack Made on South: Names of Tillman, Vardaman, Dixon, and Hopkinson Smith Hissed," The Atlanta Constitution, February 3, 1906.

902 Samuel K. Roberts, "Kelly Miller and Thomas Dixon on Blacks in American Civilization," Phylon 41, no. 2 ( $2^{\text {nd }}$ Quarter, 1980): 204-206.

903 Ibid.

${ }^{904}$ Kelly Miller, As to the Leopard's Spots: An Open Letter to Thomas Dixon, Jr. (Washington, D.C.: Hayworth Publishing House, 1905).

${ }^{905}$ Kelly Miller, “Argues for His Race: Kelly Miller Writes to Dixon,” Boston Daily Globe, September 24, 1905.
} 
time to evolve. ${ }^{906}$ The time a race spent exposed to civilization was crucial in advancement, and Miller used Romans and the Egyptians as examples of "relative superiority" being merely a "transient phase of human development." ${ }^{\text {"907 }}$ Miller cited Dixon's vehement attempts to belittle the black race as further proof that white superiority was not imminent, nor foreordained. ${ }^{908}$ In regard to African Americans' supposed inability to learn and comprehend through proper education, Miller chronicled the advances made by the black race since emancipation: "Within forty years of partial opportunity... the American Negro has cut down his illiteracy by over fifty percent; has produced a professional class... and is found in all higher lines of listed pursuits in which white men are engaged." ${ }^{909}$

Miller dismissed the novelist's accusation that miscegenation was the solution advocated by blacks as a solution to racial tensions. He questioned the blood purity thesis of Anglo-Saxonism altogether. Miller argued that most black Americans possessed a white ancestor. The institution of slavery brought about widespread, if unacknowledged, miscegenation in the South while prostitution perpetuated it in the North. ${ }^{910}$ "It seems to me," he maintained, "that this frantic abhorrence of amalgamation is a little late in its appearance. Whence comes this stream of white blood which flows

\footnotetext{
${ }^{906}$ Miller, As to the Leopard's Spots, 9.

${ }^{907}$ Ibid, 6.

${ }^{908}$ Ibid.

${ }^{909}$ Roberts, "Kelly Miller and Thomas Dixon on Blacks in American Civilization," 204-206.

${ }^{910}$ Miller, As to the Leopard's Spots, 13-17.
} 
with more or less spissitude, in the veins of some six out of ten million Negroes?"911 Instead of preventing miscegenation, Dixon's racial hatred fostered its continuance by making whiteness the prerequisite for national success. As whiteness became the standard for admittance into formal American society, according to Miller, light-skinned African Americans married white partners. These unions produced visually white children, who were nonetheless products of race mixing. ${ }^{912}$

As Dixon's messages entered the widespread fervor regarding the problem of race, criticisms of the Reconstruction Trilogy, in particular, launched him full force into the national argument. Through public events and publications, he defended his positions in three different ways: undermining the legitimacy of his critics, using biological and Anglo-Saxonist theories of race, and warnings about an impending race war. His first tactic involved dismissing criticisms of his work, sometimes to the point of mocking the critics. "I owe much to my critics," he wrote to the New York Times, "They are all my good friends, and none more so than mine enemies among them."913 The author leveled accusations of bias at some of his detractors, insisting they "simply read into the book their own feelings and National bias."914 "Small fry" reviewers, he declared, pounced "on an unimportant blemish... instead of reviewing the book" in order to boost their

\footnotetext{
${ }^{911}$ Miller, As to the Leopard's Spots, 13-17.

912 Ibid.

913 Thomas Dixon, Jr., “'The Clansman,' Its Authors, Thomas Dixon, Jr., Replies with Spirit and Good Humor to Some of His Critics," New York Times, February 25, 1905.

914 Thomas Dixon, “An Author’s Answer to His Critics,” New York Times, August 9, 1902.
} 
personal reputations and paper sales. ${ }^{915}$ In other instances, "where critics happened to know that I was once a clergyman they are almost sure to complain of my "preaching,"” Dixon charged, but "they invariably write that criticism before they read the book." Furthermore, he asserted, "all novelists are preachers, always have been and always will be... a novelist who has no faith to proclaim, no view of life to teach, is simply a fool who has nothing to say and spoils tons of good paper trying to say it."916 Others were inconsistent, Dixon charged, at first accusing him of "ignorance," but later labeling him "the biggest liar that ever walked the face of the earth because I know the truth but falsify it maliciously." ${ }^{.917}$

Another method Dixon used to justify the trilogy was reiterating the historical authenticity of his works. Reflecting his graduate school training and intellectual investment in historical evidence, he often focused on his source materials. In publications and interviews, Dixon revealed that the heroes in the Reconstruction Trilogy had been partially modeled after his own uncle, Leroy McAfee. The author traced his family and the Ku Klux Klan to Scotch Covenanter migrants, and asserted, "no adequate history of America will be written until full credit be given the people of Covenanter blood for the part they played in creating the nation and developing its life." ${ }^{918}$ In another interview, Dixon identified some of the actual figures characters in the trilogy

\footnotetext{
915 "Mr. Thomas Dixon Writes," The Bookman: An Illustrated Magazine of Literature and Life (New York: Dodd, Mead and Company, 1903), 348-350.

${ }^{916}$ Ibid.

${ }^{917}$ Ion Clifford, "Rockefeller a Hero of Romance: Thomas Dixon Outlines a Trilogy on SocialismExplains Lesson of his Negro Trilogy," New York Times, August 10, 1907.

${ }^{918}$ Dixon, "The Story of the Ku Klux Klan: Some of Its Leaders, Living and Dead," 660.
} 
were based upon. In The Leopard's Spots, the political side of Charles Gaston was drawn "from the present executive of North Carolina, Governor Aycock."919 The old soldier character, Tom Camp represented Dixon's cousin, Nathaniel Camp, a former Confederate soldier that told the author war stories when he was a child. ${ }^{920}$ In addition to personal experience and relatives' biographies, the author emphasized the eighteen months he spent researching the history of Reconstruction. Dixon challenged "any man in the United States" questioning the trilogy's historical narrative to "ask the American Historical Society their opinion on the matter," offering a thousand dollars "against him and above the verdict." 921 He waded through "more than four thousand volumes of historical and controversial material," which, he claimed, provided "sworn documentary evidence for every incident." 922

White nationalism and the idea of an impending race war formed the foundation of Dixon's defense of the Reconstruction Trilogy. He argued that assimilating African Americans into the fabric of the voting population meant the "extinction of national character," of America's vital whiteness. ${ }^{923}$ "I sense nothing but tragedy in the course it [the Race question] is taking," he warned, and "I have given and am giving the best

\footnotetext{
919 “Passing Throng," The Atlanta Constitution, September 24, 1902.

${ }^{920}$ Ibid.

921 “Tom Dixon Talks of The Clansman: The Author Discusses His Critics and His Friends," The Atlanta Constitution, October 29, 1905; "'The Clansman' At Show: Thomas Dixon, in Speech to Audience, Outlines His Mission,” The Sun (Baltimore), April 30, 1907.

${ }^{922}$ Thomas Dixon, Jr., "Mr. Dixon Explains: It Would Have Been 'Impossible’ for Him to Acknowledge His Indebtedness to Dr. Craven in a Preface," New York Times, March 25, 1905; "Tom Dixon Talks of The Clansman: The Author Discusses His Critics and His Friends," The Atlanta Constitution, October 29, 1905.

${ }^{923}$ Thomas Dixon, The Clansman: An American Drama, 35.
} 
energies of my life to preserve the purity of our race and avoid a slowly approached, but inevitable conflict."924 The Reconstruction Trilogy, he claimed, was a "sole protest against this threatening degradation of our racial stock," designed to "save the negro from opprobrium and the white race from a degraded mongrelism.. ${ }^{925}$ Late-nineteenth century racial science informed his ideology. Dixon argued a significant "physical difference" existed between the races, the product "of thousands of years of inherited progress" which separates the child of the Aryan from the child of the African." 926 Instincts of "self-preservation," he insisted, governed white prejudice against nonwhite races. ${ }^{927}$ In this formulation, African Americans occupied a low place on the racial scale. Throughout history, he maintained, "millions of Africans" contributed "absolutely nothing" to human progress. He condemned people of African descent as an inferior "half-child, half animal," group of manual laborers, "with a racial record of four thousand years of incapacity." 928

For Dixon, African Americans' biologic inferiority precluded rectification through education. It had, he insisted, "exactly the contrary effect" by breeding

\footnotetext{
${ }^{924}$ Ion Clifford, "Rockefeller a Hero of Romance: Thomas Dixon Outlines a Trilogy on SocialismExplains the Lesson of His Negro Trilogy," New York Times, August 10, 1907; Thomas Dixon, Jr., "From the People: An Irrepressible Conflict, Thomas Dixon, Jr., Author of 'The Clansman,' on Northern Doctrine of Social Equality with Negroes,” The Sun (Baltimore), April 18, 1906.

925 “'The Clansman' At Show: Thomas Dixon, in Speech to Audience, Outlines His Mission," The Sun (Baltimore), April 30, 1907.

${ }^{926}$ Dixon, The Clansman: An American Drama, 29.

927 "Kinds of Race Prejudice: They Result, Says Dr. Dixon, from Fear of Superior Powers and from the Instinct of Self-Preservation," Boston Daily Globe, June 9, 1903.

${ }^{928}$ Dixon, The Clansman: An American Drama, 29-31; "Preacher Predicts Race War: The Rev. Thomas Dixon Says Anglo-Saxons Will Wipe Out Race Made Into Monstrosities by Education," Chicago Daily Tribune, February 23, 1903.
} 
discontent throughout the nation. ${ }^{929}$ Thus, Dixon condemned even the benign education initiatives of Booker T. Washington. Though "the aim of his work is noble and inspiring," Dixon wrote, "it will not solve the Negro problem nor bring us within sight of its solution... it will only intensify that problem's dangerous features, complicate and make more difficult its ultimate settlement." "No scheme of education or religion" would solve the race problem, he argued, because schooling "never did and never will alter the essential character of any man or race of men," and "no amount of education" could "bridge the chasm of the centuries which separate him [blacks] from the white man in the evolution of human civilization." 930 "Mr. Washington's brand of education," Thomas Dixon asserted, widened the gulf between whites and African Americans by building "a nation inside a nation of two hostile races... storing dynamite beneath the pathway of our children - the end at last can only be in bloodshed." ${ }^{931}$

This "bloodshed" reference provided another justification for Dixon's ideology. It appeared to Dixon that racial animosities had increased exponentially at the turn-ofthe-century, and he warned of an inevitable "race war." ${ }^{932}$ Economic competition between the races, in his argument, was one force driving racial hatreds. Efforts to elevate blacks' economically brought them into direct competition with white laborers, an

\footnotetext{
929 “'New America' a Fact: Mr. Thomas Dixon, Jr., Says the Spanish War United It," The Sun (Baltimore), November 12, 1902.

${ }^{930}$ Dixon, The Clansman: An American Drama, 29-31.

${ }^{931}$ Ibid, 35-37.

932 "Preacher Predicts Race War: The Rev. Thomas Dixon Says Anglo-Saxons Will Wipe Out Race Made Into Monstrosities by Education," Chicago Daily Tribune, February 23, 1903.
} 
incarnation of "war — the most fierce and brutal of all its forms." that demands for political equality threatened to incite a race war by legalizing racial intermarriage. To him, political equality would lead to social equality, and social equality meant legal marriages for mixed race couples. He accused African American leaders of desiring miscegenation in efforts to eliminate racism by creating a "new race" that would "become the dominant factor in the life of the new nation." The purpose of their work, he maintained, was to make social equality inevitable through "the future heaven of amalgamation." ${ }^{934}$ Interracial couplings needed to be prevented, he maintained, in order to preserve the nation "from the degradation of mulatto mongrelism." ${ }^{935}$ Without nationwide "iron laws against miscegenation," Dixon feared the "whole civilization would continue to tremble in the balance" of current tensions. ${ }^{936}$ "The greatest calamity which could possibly befall this Republic," he asserted, "would be the corruption of our national character by the assimilation of the Negro race." ${ }^{.937}$

Dixon warned of a future race war that would be national in scale. He predicted the "first serious racial conflict" would occur "in the North—in New York, Chicago, or Philadelphia — and not in the South." ${ }^{.938}$ Failing to curb "the liberties that the Negro is

\footnotetext{
933 "Preacher Predicts Race War: The Rev. Thomas Dixon Says Anglo-Saxons Will Wipe Out Race Made Into Monstrosities by Education," Chicago Daily Tribune, February 23, 1903. 
allowed in the North," which he believed led to parallel equality demands in the South, would lead to "some of the bloodiest riots... that this country has ever known."939 According to Dixon's argument, "the law is unable to cope with the situation" or to prevent acts of violence. ${ }^{940}$ Instead, white Americans held responsibility to alter the status quo "when the published formulas of law have been outgrown by the race, or its forms...perverted so that they no longer are the expression of the organized virtue of the race." In his view, this could include extralegal tactics to protect the nation's white purity, since "many of the men whom we owe the progress of the world were executed as criminals by the official guardians of society." 941 Dixon refrained from requesting organized vigilante violence, fearing that groups emerging in 1905, like Birmingham's Sons of the Clansman were "a little premature," but predicted "some league will in the course of time become a necessity in America." 942

Dixon championed colonization as the ideal solution to America's racial problems for a variety of reasons. First, he considered colonization a tangible economic answer to race tensions and economic problems, one that would cost less than education programs for African Americans. ${ }^{943}$ "No sudden strain on the labor market" would emerge, he claimed, for his colonization was a gradual process designed to replace departing blacks

\footnotetext{
939 “Will Be Riots Here-Dixon,” New York Times, September 24, 1906.

940 Ibid.

${ }^{941}$ Dixon, The Clansman: An American Drama, 61.

942 "Dixon on Race Problem: Says a New Ku Klux Klan in the South is a Little Premature," New York Times, November 28, 1905.

943 “The Past and Future of Liberia," The Sun (Baltimore), August 27, 1905.
} 
with Anglo Saxon immigrants. ${ }^{944}$ He thought the period's changing demographics resulted in new possibilities and that the time was ripe for pushing his agenda, since the nineteenth-century cultural stigma against white fieldwork was disappearing. African American migration out of the region and the opening another of option to the Southern states in the form of white immigrants exploded "the idea that a white man cannot work in the fields," he maintained. ${ }^{945}$

Second, Dixon argued that colonization would prevent the looming race conflict and preserve the purity of white America. Without removal, he envisioned a race war within fifty years: the nation faced the choice to "remove the Negro" or "to fight him." "Peaceful and friendly colonization" offered the only solution for avoiding this inevitable conflict. ${ }^{946}$ By permitting black education, the nation was "deceiving him [African Americans] and allowing him to deceive himself." 947 A "square deal" for African Americans, according to Dixon, remained unattainable if the nation wanted to remain white. The founding principle of equality presented the country with a paradox: according the Constitution, African Americans deserved democratic equality, but Dixon argued that to grant it meant the end of national success. Furthermore, the denial of blacks' suffrage rights, though necessary at the time, would only solve the situation for a temporary period. If blacks stayed in the nation without some sort of intervention, Dixon insisted "no halfway place" existed; African Americans could be only "servant or

\footnotetext{
944 “Will Be Riots Here-Dixon,” New York Times, September 24, 1906.

${ }^{945}$ Dixon, The Clansman: An American Drama, 37.

946 "Deems Negro a Menace: Whites Must Deport or Fight Him, Says Thomas Dixon, Nearly Starts a Church Row," The Sun (Baltimore), January 29, 1906.

947 "The Past and Future of Liberia," The Sun (Baltimore), August 27, 1905.
} 
master." Though Dixon displayed confidence in the Anglo Saxon race's ability to "wipe out" rebelling black Americans, he claimed contemporary African American activists produced "a magnificent fighting animal" prepared to overtake the country "with a repeating rifle in his hand." ${ }^{" 948}$

Third, Dixon insisted colonization provided black Americans with an option to be a truly free self-governing people. He proposed establishing a colony of half a million blacks in Monrovia, the capital of Liberia within two years where the first generation of settlers "could lay the foundations of a free black republic, which within twenty five years would solve our race problem on the only rational basis within human power." ${ }^{\prime 49}$ In the United States, he argued, "overwhelming forces" had denied African Americans the "opportunity for the highest, noblest, and freest development of his full, rounded manhood." ${ }^{950}$ He believed colonization offered African Americans the chance to "grow of his own accord," using "ideas of government and kindred topics" absorbed during the race's time in America. ${ }^{951}$ Dixon praised African American advocates of colonization as representatives of a contingent of "more intelligent Negroes" that realized the many challenges of obtaining equality in the United States. ${ }^{952}$

Dixon released his long-awaited film adaptation of the Reconstruction Trilogy on February 8, 1915. From a small loft in Union Square, where Epoch Producing

\footnotetext{
948 "Deems Negro a Menace: Whites Must Deport or Fight Him, Says Thomas Dixon, Nearly Starts a Church Row," The Sun (Baltimore), January 29, 1906.

949 "The Past and Future of Liberia," The Sun (Baltimore), August 27, 1905.

${ }^{950}$ Dixon, The Clansman: An American Drama, 27.

951 “Will Be Riots Here-Dixon,” New York Times, September 24, 1906.

${ }^{952}$ Ibid.
} 
Corporation was housed, Dixon and filmmaker D.W. Griffith began planning the production of a Civil War epic. ${ }^{953}$ Immediately, their production schedule met difficulties. By 1914, as production approached actual filming, the horses and cotton fabric needed for the actors to properly represent the Ku Klux Klan were scarce, commandeered for the European war effort. ${ }^{954}$ Quickly, production exceeded the $\$ 40,000$ budget. Three separate times the men were forced to suspend production of the film because they lacked sufficient funds. Eventually, the cast and crew donated their salaries to assist in making The Birth of a Nation a reality, funding the last of the film's $\$ 112,000$ production expenses. ${ }^{955}$

The Birth of a Nation premiered in Los Angeles at Clune's Auditorium under the name The Clansman. ${ }^{956}$ Dixon insisted on renaming the work after its theme of national unity springing from the atrocities of the Civil War. The Birth of a Nation, according to Dixon, depicted "the agony which the South endured that a nation might be born." 957 The first half of the film is set during the Civil War, telling a tale of two families: one Northern, one Southern. After intermission, the second half of the film connected the

\footnotetext{
${ }^{953}$ See Stokes, D.W. Griffith's 'The Birth of a Nation' (2007) to find additional details about the relationship between Dixon and Griffith during the filmmaking process. For more on D.W. Griffith, see: David Mayer, Stagestruck Filmmaker: D.W. Griffith and the American Theatre (Iowa City: University of Iowa Press, 2009); Robert Lang, ed. The Birth of a Nation: D.W. Griffith, Director (1994); Scott Simmon, The Films of D.W. Griffith (New York: Cambridge University Press, 1993); Tom Gunning, D.W. Griffith and the Origins of American Narrative Film: The Early Years at Biograph (Urbana: University of Illinois Press, 1991); and Robert M. Henderson, D.W. Griffith: His Life and Work (New York: Oxford University Press, 1972).

${ }^{954}$ Cook, Fire From the Flint, 165.

${ }^{955}$ Ibid; see also: Slide, American Racist, 71-89.

${ }^{956}$ Thomas Cripps, Slow Fade to Black: The Negro in American Film, 1900-1942 (New York: Oxford University Press, 1977), 52-53.

${ }^{957}$ Merritt, "Dixon, Griffith, and Southern Legend," 39.
} 
mission of the KKK is connected to the origins of the Civil War, using lines from President Woodrow Wilson's A History of The American People: "The white men were roused by a mere instinct of self-preservation... until at last there had sprung into existence a great Ku Klux Klan, a veritable empire of the South, to protect the Southern country."958 The images claim to "have conveyed to the mind the ravages of war to the end that war may be held in abhorrence, this effort will not have been in vain."959 The second half of the film is set during Reconstruction, where black politicians and the Radical Republicans worked together to disenfranchise white Southerners. African Americans in the South are portrayed a lawless, vicious, sexualized, and depraved threats to the survival of the nation. The vigilante efforts of the Ku Klux Klan are idolized as the saving grace of the South. ${ }^{960}$

Dixon's Reconstruction themed works left an enduring mark on American culture. Widespread distribution of his Reconstruction works assisted in perpetuating Dunning School narratives of Reconstruction history and negative stereotypes of blackness into the national memory. The stage and film versions of the Reconstruction Trilogy also had effects Dixon did not anticipate, such as the resulting creation of a second Ku Klux Klan, which grew to considerable political strength in the 1920s. In addition, his works helped catalyze early-twentieth century civil rights efforts, and

\footnotetext{
${ }^{958}$ D.W. Griffith, Thomas Dixon, Jr. and Frank E. Woods. Birth of a Nation, DVD. Directed by D.W. Griffith. Image Entertainment, 1998.

${ }^{959}$ Ibid.

${ }^{960}$ Michael Rogin, “The Sword Became a Flashing Vision,” 151.
} 
participants from all over the country protested against the portrayals of African

Americans in The Clansman and in The Birth of a Nation.

The Birth of a Nation, in particular, triggered long-lasting socio-cultural

developments. ${ }^{961}$ One reason it remains notable is for a series of firsts in cinema history that "revolutionized moviegoing:" it was the first film to last three hours; the first to cost more than $\$ 100,000$ to produce; the first to be screened at regular theaters with the same admission prices as live entertainment options; the first to have a specially compiled accompanying musical score; the first movie shown at the White House and to be projected in front of the Supreme Court and Congress; and perhaps most importantly, the first cinematic work seen by countless everyday Americans. ${ }^{962}$ The film also contributed to the hardening of the white-black racial dichotomy; racial tensions throughout the nation were as divided as they had been at the end of the nineteenth century. Inspired by Dixon's film, the Ku Klux Klan was reborn in late 1915 and experienced widespread popularity, directly opposing the efforts of black organizations. ${ }^{963}$ That same year, as it

\footnotetext{
${ }^{961}$ For more about the legacy of The Birth of a Nation, as a film, see: Mark E. Benbow, "Birth of a Quotation: Woodrow Wilson and 'Like Writing History with Lightning'," Journal of the Gilded Age and the Progressive Era 9, no. 4 (October 2010): 509-533; Dick Lehr,The Birth of a Nation: How a Legendary Filmmaker and a Crusading Editor Reignited America's Civil War (New York: PublicAffairs, a member of Perseus Books, 2014); Godfrey Cheshire, "Why No One is Celebrating the $100^{\text {th }}$ Anniversary of the Feature Film," Southern Cultures 21, no. 4 (Winter 2015): 28-37.

962 Stokes, D.W. Griffith's 'The Birth of a Nation,' 3.

963 To locate more information on the early-twentieth century Ku Klux Klan, consult: Tom Rice, White Robes, Silver Screens: Movies and the Making of the Ku Klux Klan (Bloomington: Indiana University Press, 2015); Adam Laats, "Red Schoolhouse, Burning Cross: The Ku Klux Klan of the 1920s and Educational Reform," History of Education Quarterly 52, no. 3 (August 2012): 323-350; Kelly J. Baker, Gospel According to the Klan: The KKK's Appeal to Protestant America, 1915-1930 (Lawrence: University Press of Kansas, 2011); Rory McVeigh, The Rise of the Ku Klux Klan: Right-Wing Movements and National Politics (Minneapolis: University of Minnesota Press, 2009); Nancy MacLean, Behind the Mask of Chivalry: The Making of the Second Ku Klux Klan (New York: Oxford University Press, 1994); Kenneth T. Jackson, The Ku Klux Klan in the City, 1915-1930 (Chicago: Ivan R. Dee, 1992); and David M.
} 
campaigned against The Birth of a Nation, the NAACP's membership doubled, and the organization began moving away from emphasizing legal avenues of enacting change in favor of a more militant approach to public protest. ${ }^{964}$

1915 marked the Golden Anniversary of the end of the Civil War. Widely celebrated by blacks and whites alike, the anniversary also served to revive white prejudices and remind African Americans of their former status as slaves. ${ }^{965}$ Prominent individuals called the film "history revitalized," and recommended people to "go see it, for it will make a better American of you." ${ }^{966}$ Various historians asserted that it was worth seeing for educational value, stirring secondary school teachers to take their classes to special film showings. White ministers supported the film from the pulpit. The film even received the endorsement of the White House after being granted the honor of the first motion picture screened at the President's home. President Wilson described the film as "writing history with lightning. My only regret is that it's all so terribly true." "967

Chalmers, Hooded Americanism: The History of the Ku Klux Klan, Third ed. (Durham: Duke University Press, 1965).

\footnotetext{
964 See: Susan Powell, “'By This Device We Can Stir Them': The Birth of a Nation and the Origins of the Civil Rights Movement," M.A. Thesis (University of North Alabama, 2010); Gilbert Jonas, Freedom 's Sword: The NAACP and the Struggle Against Racism in America, 1909-1969 (New York: Routledge, 2005); Stephen Weinberger, "The Birth of a Nation and the Making of the NAACP," Journal of American Studies 45, no. 1 (2011): 77-93; Josh Glick, "Mixed Messages: D.W. Griffith and the Black Press, 19161931," Film History 23, no. 2 (2011): 174-195; and Jenny Woodley, Art for Equality: The NAACP's Cultural Campaign for Civil Rights (Lexington: University Press of Kentucky, 2014)

965 Cripps, Slow Fade to Black, 26.

${ }^{966}$ Merritt, “Dixon, Griffith, and Southern Legend,” 28.

967 This quote may have been falsely attributed, but shaped the memory and reception of the film nonetheless. See Mark E. Benbow, "Birth of a Quotation," 509-533.
} 
The film also ignited a wave of protest. $^{968}$ In cities across the nation, African American organizations and groups demanded the film's censorship, either of specifically offensive scenes or in general. In some cases, they took their complaints to the state legislatures. ${ }^{969}$ In some cities, such as Boston, these efforts at scene censorship were successful. Before the film reached the east coast, the West Coast branches of the NAACP had sent warnings about the film's contents to their East Coast counterparts. NAACP Secretary, Mary Childs Nerney, distributed pamphlets to NAACP members and African Americans on the street, warning of the film and reminding them about the stage version of The Clansman nine years prior. ${ }^{970}$ Soon, the NAACP demanded censorship on a national scale.

Beginning in Los Angeles, and spreading throughout the nation, chapters of the NAACP called for restriction of the film at the same time that the Epoch Corporation, the film's distributor, mounted a massive advertising campaign. National divisions led audiences to become "mobs for or against the Reverend Thomas Dixon's poisonous

\footnotetext{
${ }^{968}$ Further information about domestic protests of The Birth of a Nation may be found in: Goodwin Berquist and James Greenwood, "Protest Against Racism: 'The Birth of a Nation' In Ohio," Journal of the University Film Association 26, no. 3 (1974): 39-44; “'The Clansman' on Stage and Screen: North Carolina Reacts," The North Carolina Historical Review 64, no. 2 (April 1987): 139-161; Arthur Lennig, "Myth and Fact: The Reception of 'The Birth of a Nation'," Film History 16, no. 2 (2004): 117-141; David Rylance, "Breech Birth: The Receptions to D.W. Griffith's 'The Birth of a Nation'," Australasian Journal of American Studies 24, no. 2 (December 2005): 1-20; Kimberley Mangun, "'As Citizens of Portland We Must Protest': Beatrice Morrow Cannady and the African American Response to D.W. Griffith's 'Masterpiece'," Georgia Historical Quarterly 107, no. 3 (Fall 2006): 382-409; Paul Polgar, "Fighting Lightning with Fire: Black Boston's Battle Against 'The Birth of a Nation'," Massachusetts Historical Review 10 (2008): 84-113; Amy Louise Wood, "With the Roar of Thunder: The Birth of a Nation," in Lynching and Spectacle: Witnessing Racial Violence in America, 1890-1940 (Chapel Hill: University of North Carolina Press, 2009); and Modupe Labode, “'Defend Your Manhood and Womanhood Rights': The Birth of a Nation, Race, and the Politics of Respectability in Early-Twentieth Century Denver, Colorado," Pacific Historical Review 84, no. 2 (May 2015): 163-194.

969 “Colored People Storm State House,” Boston Daily Globe, April 19, 1915.

${ }^{970}$ Cripps, Slow Fade to Black, 52-56.
} 
hatred of the Negro."971 The cultural and political climate of the nation offered the NAACP little support in denouncing The Birth of a Nation. The organization responded to increased advertisement and endorsement with intensified polemics against the film. The NAACP filed criminal proceedings against Griffith, proceeded with a case against Epoch, and continued calling for the film's boycott. ${ }^{972}$ Their lawsuits largely failed.

They were successful in their efforts at scene censorship: two scenes were left out of the film. In most cities, however, the battle continued.

Multiple demonstrations and protests did not stop Birth of a Nation from success, which it found on a global scale. By mid-1916, Dixon's film adaptation of the Reconstruction Trilogy was being screened in the United Kingdom, Canada, Australia, New Zealand, and a variety of other Latin American and European countries. Though the film received mixed receptions in several places, The Birth of a Nation set records at the box office, earning an estimated $\$ 100$ million from viewers. ${ }^{973}$ Historian Melvyn Stokes, who wrote the most current definitive work on The Birth of a Nation, estimates the film may have been seen by as many as $200,000,000$ people worldwide. ${ }^{974}$

\footnotetext{
${ }^{971}$ Cripps, Slow Fade to Black, 52-56.

972 Ibid.

${ }^{973}$ For more on international responses to The Birth of a Nation, see: Michael Hammond, "'A Soul Stirring Appeal to Every Briton': The Reception of 'The Birth of a Nation' in Britain, 1915-1916," Film History 11, no. 3 (1999): 353-370; Melvyn Stokes "Race, Politics, and Censorship: D.W. Griffith's The Birth of a Nation in France, 1916-1923," Cinema Journal 50, no. 1 (Fall 2010): 19-38; Brian Willan, "'Cinematographic Calamity' or 'Soul-Stirring Appeal to Every Briton': Birth of a Nation in England and South Africa, 1915-1931,” Journal of Southern African Studies 39, no. 3 (2013): 623-640; and Greg Marquis, “A War Within a War: Canadian Reactions of D.W. Griffith's The Birth of a Nation," Social History 47, no. 94 (2014): 421-442.

974 These figures are estimates, as there are no reliable hard numbers from the period. See: Stokes, D. W. Griffith's 'The Birth of a Nation,' 3; 287.
} 
The period surrounding the film's release, however, marked the beginning of the end of Dixon's public popularity. After 1915, he attempted to build a career in film by (unsuccessfully) opening a film studio in California, and slowly faded in the public eye. The last decades of Dixon's life mirrored the early ones. He again possessed multiple careers and remained dedicated to political issues, though his works no longer reached their previous levels of popularity. Following The Birth of a Nation's release, he worked on eighteen various film and stage projects as a writer or director, while simultaneously continuing to write about sectionalism, race, socialism, and the nation's future in a modern world. ${ }^{975}$ He published fourteen books, campaigned for (and later against) Franklin D. Roosevelt as a presidential candidate, opened a liberal arts camp, and began countless unfinished projects before his death. ${ }^{976}$ By 1934, thanks to the Great Depression, his wealth had dissipated. In 1937, at the age of seventy, he became clerk of the federal court for the eastern district of North Carolina and his wife, Harriet, died. Two years later, Dixon suffered a debilitating cerebral hemorrhage from which he never fully recovered and married Madelyn Clare Donovan, an actress in one of his films. ${ }^{977}$ Even as his health deteriorated, he railed against the dangers of racial equality and socialism in his last novel, The Flaming Sword (1939). On April 3, 1946, Dixon died penniless in Raleigh. He is buried at the Sunset Cemetery in his hometown of Shelby alongside other local notables, including historian of Southern culture, W.J. Cash (1900-

\footnotetext{
${ }^{975}$ Anthony Slide's American Racist (2004) covers Dixon's film career in its entirety, from Birth of a Nation forward.

${ }^{976}$ Cook, Fire From the Flint, 206-235; Slide, American Racist, 188-195; Dixon's liberal arts summer camp project was called Wild Acres in the Sky, and located on Mount Mitchell in North Carolina. He bought over a thousand acres of land and built two lodges, with the intent of eventually constructing an entire retreat. The Great Depression, however, stripped Dixon of his fortune.

${ }^{977}$ Cook, Fire From the Flint, 229-235; Slide, American Racist, 193.
} 
1941), U.S. Congressman and federal judge, Edwin Yates Webb (1872-1955), former North Carolina governor, Oliver Max Gardner (1882-1947), and former North Carolina governor and U.S. Congressman, Clyde R. Hoey (1877-1954). 


\section{$\underline{\text { Epilogue }}$}

The legacy of Dixon's Reconstruction Trilogy strengthens this dissertation's insistence on the reciprocity between individuals and their times. Many of Dixon's ideas about whiteness, Civil War and Reconstruction, and their relation to the nation's political trajectory appeared in professional histories written by the "Dunning School" of scholars, and were a standard interpretation throughout much of the U.S. during the mid-twentieth century. The Birth of a Nation spawned the birth of a new Ku Klux Klan in 1915, which grew to substantial political strength, and played a pivotal role in the strained race relations of the interwar period. Dixon, ironically, hated the early-twentieth incarnation of the Ku Klux Klan, arguing that it perpetuated both regional and racial problems, thus harming the nation's path to progress. In another development, the virulent anti-black sentiment of the Reconstruction Trilogy also helped to strengthen the public presence of African American equal rights movements in the early-twentieth century.

One hundred years after The Birth of a Nation premiered, eliminating sectionalism, ending racial tensions, and the details of citizenship remain open-ended questions. In a way that would have displeased Dixon, and, ironically, as a result of works like his, the American South and race remain inextricably intertwined in the collective memory. Regional interpretations of history remain a key point of contention: In the summer of 2015, popular culture and media branded the Confederate flag as an unAmerican symbol of hatred, reinforcing the connection between the South and racism. Confederate flags were removed from state capitals and veterans' cemeteries throughout the following year. This cultural rejection of the Confederate flag was not wholesale, 
though, as many Southerners steadfastly argued the flag stood for honor, states' rights, and even Southern heritage, demonstrating the powerful and long-lasting effects the Dixon-esque interpretation of history. This power extended to the public memory, as no federally funded museum is dedicated solely to slavery and the experiences of bonded peoples in the U.S. The subject is usually worked into museums piecemeal: the Old Slave Mart in Charleston, South Carolina has a small exhibit on the early slave trade that took place within its walls; some general information about slavery also appears at the National Underground Railroad Freedom Center in Cincinnati, Ohio, and the National Civil Rights Museum in Memphis, Tennessee. The anticipated National Museum of African American History and Culture will continue this pattern by including features on a variety of black historical topics from slavery to pop culture icons. ${ }^{978}$

A century later, intellectuals, artists, and activists, are still fighting to overturn the narrative of history perpetuated by works like Dixon's. Like W.E.B. DuBois' work on Reconstruction, these individuals are using the media to put black history at the forefront of mainstream American history. Thanks to the private funds and legal efforts of John Cummings, the first museum dedicated to the history of American slavery opened in late 2014, housed in the former Whitney Plantation in Louisiana. ${ }^{979}$ Films like Django Unchained, which was filmed at Whitney Plantation, and 12 Years a Slave have brought the experiences of former African American activists to life, revealed the brutality of

\footnotetext{
${ }^{978}$ David Amsden, "Building the First Slavery Museum in America," The New York Times Magazine, February 26, 2015.

${ }^{979}$ Ibid.
} 
antebellum slavery, and overturned mainstream acceptance of the plantation ideal of Dixon's time.

Dixon's work remains an influence and a topic for revision here: In 2006 a "hip hop remix" of modern music jumbled with scenes from Dixon and Griffith's silent film, titled Rebirth of a Nation, showed at the Lincoln Center in New York. ${ }^{980}$ A new The Birth of a Nation film debuted this year, and portrays historical events surrounding the Nat Turner slave rebellion of 1831. The movie's writer, producer, and director, Nate Parker made a purposeful, informed choice in the work's moniker. As Parker explained his motivations to Filmmaker magazine, he had "reclaimed this title and repurposed it as a tool to challenge racism and white supremacy in America, to inspire a riotous disposition toward any and all injustice in this country... and to promote the kind of honest confrontations that will galvanize our society toward healing and sustained systemic change."981 Like its namesake, the 2016 Birth of a Nation already set records, with Parker securing a $\$ 17.5$ million distribution deal— the biggest in Sundance Film Festival history. ${ }^{982}$

\footnotetext{
${ }^{980}$ Cheshire, "Why No One is Celebrating the $100^{\text {th }}$ Anniversary of the Feature Film," 35-37.

${ }^{981}$ Soheil Rezayazdi, "Five Questions with The Birth of a Nation Director Nate Parker," Filmmaker: The Magazine of Independent Film, January 25, 2016, http://filmmakermagazine.com/97103-five-questionswith-the-birth-of-a-nation-director-nate-parker/\#.V2CIDGa4S2B, accessed April 21, 2016.

982 Jen Yamato, “'The Birth of a Nation': Meet Nate Parker, The Revolutionary Filmmaker Begin the Sundance Smash," The Daily Beast, January 18, 2016, http://www.thedailybeast.com/articles/2016/01/28/the-birth-of-a-nation-meet-nate-parker-therevolutionary-filmmaker-behind-the-sundance-smash.html, accessed April 21, 2016.
} 


\section{Bibliography}

Adams, Bluford. "World Conquerors or a Dying People? Racial Theory, Regional Anxiety, and the Brahmin Anglo-Saxonists." The Journal of the Gilded Age and Progressive Era 8, no. 2 (April 2009): 189-215.

Adcock, Robert, Mark Bevir, and Shannon C. Stimson, eds. Modern Political Science: Anglo-American Exchanges Since 1880. Princeton: Princeton University Press, 2007.

Adeleke, Tunde. UnAfrican Americans: Nineteenth Century Black Nationalists and the Civilizing Mission. Lexington: University Press of Kentucky, 1998.

Alexander, Roberta Sue. North Carolina Faces the Freedmen: Race Relations During Presidential Reconstruction, 1865-1867. Durham: Duke University Press, 1985.

Alexander, Shawn Leigh. An Army of Lions: The Civil Rights Struggle Before the NAACP. Philadelphia: University of Pennsylvania Press, 2012.

Ali, Omar H. In the Lion's Mouth: Black Populism in the New South, 1886-1900. Oxford: University Press of Mississippi, 2010.

Allen, Thomas M. A Republic in Time: Temporality and Social Imagination in Nineteenth-Century America. Chapel Hill: University of North Carolina Press, 2008.

Allison, Clinton B. "The Conference for Education in the South: An Exercise in Noblesse Oblige." Journal of Thought 16, no. 2 (Summer 1981): 39-55.

Anderson, Eric and Alfred A. Moss, Jr. Dangerous Donations: Northern Philanthropy and Southern Black Education, 1902-1930. Columbia: University of Missouri Press, 1999.

Anderson, James D. The Education of Blacks in the South. Chapel Hill: University of North Carolina Press, 1988.

Anderson, Stuart. Race and Rapprochement: Anglo-Saxonism and Anglo-American Relations, 1895-1904. Rutherford: Fairleigh Dickinson University, 1981.

Ayers, Edward L. The Promise of the New South: Life After Reconstruction. New York: Oxford University Press, 1992.

- Southern Crossing: A History of the American South, 1877-1906. New York: Oxford University Press, 1995. 
Babb, Valerie N. Whiteness Visible: The Meaning of Whiteness in American Literature. New York: New York University Press, 1998.

Bailey, Julius. Race Patriotism: Protest and Print Culture in the A.M.E. Church. Knoxville, University of Tennessee Press, 2012.

Baker, Bruce. What Reconstruction Meant: Historical Memory in the American South. Charlottesville: University of Virginia Press, 2007.

Baker, Bruce W. and Brian Kelly, eds. After Slavery: Race, Labor, and Citizenship in the Reconstruction South. Gainesville: University Press of Florida, 2013.

Baker, Kelly J. Gospel According to the Klan: The KKK's Appeal to Protestant America, 1915-1930. Lawrence: University Press of Kansas, 2011.

Baker, Lee D. From Savage to Negro: Anthropology and the Construction of Race, 1896-1954. Berkeley: University of California Press, 1998.

Baker, Robin E. "Class Conflict and Political Upheaval: The Transformation of North Carolina Politics During the Civil War," North Carolina Historical Review 69 (April 1992): 148-178.

Banaji, Shakuntala and David Buckingham, eds. The Civic Web: Young People, the Internet, and Civic Participation. Boston: MIT Press, 2013.

Bannister, Robert C. Social Darwinism: Science and Myth in Anglo-American Social Thought. Philadelphia: Temple University Press, 1979.

Barkan, Elazar. The Retreat of Scientific Racism: Changing Concepts of Race in Britain and the United States Between the World Wars. Cambridge: Cambridge University Press, 1992.

Barrett, Jenny. Shooting the Civil War: Cinema, History, and American National Identity. New York: I.B. Tauris, 2009.

Barron, James Patrick. "The American Reception of Henryk Sienkiewicz's Quo Vadis?" $\mathrm{Ph}$.D. Dissertation. University of Chicago, 2005.

Bates, Beth Thompkins. "A New Crowd Challenges the Agenda of the Old Guard In the NAACP, 1933-1941." The American Historical Review 102, no 2. (April 1997): 340-377.

Bay, Mia. The White Image in the Black Mind: African-American Ideas About White People, 1830-1925. New York: Oxford University Press, 2000. 
Bederman, Gail. Manliness and Civilization: A Cultural History of Gender and Race in the United States, 1880-1917. Chicago: University of Chicago Press, 1995.

Beck, E.M. "Judge Lynch Denied: Combating Mob Violence in the American South, 1877-1950." Southern Cultures 21, no. 2 (Summer 2015): 117-139.

Beckel, Deborah. Radical Reform: Interracial Political in Post-Emancipation North Carolina. Charlottesville: University of Virginia Press, 2011.

Beckert, Sven. The Monied Metropolis: New York City and the Consolidation of the American Bourgeoisie, 1850-1896. New York: Cambridge University Press, 2001.

Beeby, James, Revolt of the Tar Heels: The North Carolina Populist Movement, 18901901. Jackson: University Press of Mississippi, 2008.

— ed. Populism in the South Revisited: New Interpretations and New Departures. Jackson: University Press of Mississippi, 2012.

Behling, Laura L. The Masculine Woman in America, 1890-1935. Urbana: University of Illinois Press, 2001.

Bell, Daniel. Marxian Socialism in the United States. Princeton: Princeton University Press, 1967.

Bell, John L., Jr. "Baptists and the Negro in North Carolina During Reconstruction." The North Carolina Historical Review 42, no. 4 (October 1965): 391-409.

Bell, Jonathan and Timothy Stanley, eds. Making Sense of American Liberalism. Urbana: University of Illinois Press, 2012.

Bellharz, Peter. Socialism and Modernity. Minneapolis: University of Minnesota Press, 2009.

Benbow, Mark E. "Birth of a Quotation: Woodrow Wilson and 'Like Writing History with Lightning,." Journal of the Gilded Age and the Progressive Era 9, no. 4 (October 2010): 509-533.

Bender, Daniel E. American Abyss: Savagery and Civilization in the Age of Industry. Ithaca: Cornell University Press, 2009.

Bensel, Richard Franklin. Yankee Leviathon: The Origins of Central State Authority in America, 1859-1877. New York: Cambridge University Press, 1990. 
- The Political Economy of American Industrialization. New York: Cambridge University Press, 2000.

Berlin, Isaiah. "History and Theory: The Concept of Scientific History." History and Theory 1, no. 1 (1960): 1-31.

Berquist, Goodwin and James Greenwood. "Protest Against Racism: 'The Birth of a Nation' In Ohio." Journal of the University Film Association 26, no. 3 (1974): 3944.

Blight, David W. Race and Reunion: The Civil War in American Memory. Cambridge: Harvard University Press, 2001.

Block, James E. A Nation of Agents: The American Path to a Modern Self and Society. Cambridge: Belknap Press of Harvard University Press, 2002.

Bloomfield, Maxwell. "The Leopard's Spots: A Study in Popular Racism.” American Quarterly 16, no. 3 (Autumn 1964): 387-401.

Blum, Edward J. Reforging the White Republic: Race, Religion, and American Nationalism. Baton Rouge: Louisiana State University Press, 2007.

Boeckmann, Cathy. A Question of Character: Scientific Racism and the Genres of American Fiction, 1892-1912. Tuscaloosa: University of Alabama Press, 2000.

Boswell, Brett David. "Unsheathing the Flaming Sword: The Racist Transformation Of Thomas Dixon, Jr.” M.A. Thesis, University of Texas at Austin, 1997.

Bouvier, Virginia Marie, ed. Whose America? The War of 1898 and the Battles to Define the Nation. Westport: Praeger, 2001.

Bowler, Peter J. Monkey Trials and Gorilla Sermons: Evolution and Christianity from Darwin to Intelligent Design. Cambridge: Harvard University Press, 2007.

Bowman, Matthew Burton. The Urban Pulpit: New York City and the Fate of Liberal Evangelicalism. New York: Oxford University Press, 2014.

Boyer, Paul. Urban Masses and Moral Order in America, 1820-1920. Cambridge: Harvard University Press, 1978.

Bradley, Mark L. Bluecoats and Tar Heels: Soldiers and Civilians in Reconstruction North Carolina. Lexington: University of Kentucky Press, 2009. 
Bradizza, Luigi. Richard T. Ely's Critique of Capitalism. New York: Palgrave Macmillan, 2013.

Brandwein, Pamela. Reconstructing Reconstruction: The Supreme Court and the Production of Historical Truth. Durham: Duke University Press, 1999.

Brantlinger, Patrick. Dark Vanishing: Discourse on the Extinction of Primitive Races, 1800-1930. Ithaca: Cornell University Press, 2003.

Brattain, Michelle. The Politics of Whiteness: Race, Workers, and Culture in the Modern South. Princeton: Princeton University Press, 2001.

Brick, Howard. Transcending Capitalism: Visions of a New Society in Modern American Thought. Ithaca: Cornell University Press, 2006.

Brisson, Jim D. "'Civil Government Was Crumbling Around Me': The Kirk-Holden War of 1870." The North Carolina Historical Review 88, no. 2 (April 2011): 123-163.

Brody, David. Visualizing American Empire: Orientalism and Imperialism in the Philippines. Chicago: University of Chicago Press, 2010.

Brogan, Denis W. "The Eclipse of Socialism in the United States." University Review 1, no. 3 (Winter 1954/1955): 29-49.

Browder, Laura. Slippery Characters: Ethnic Impersonators and American Identities. Chapel Hill: University of North Carolina Press, 2000.

Brown, Linda Joyce. The Literature of Immigration and Racial Formation: Becoming White, Becoming Other, Becoming American in the Late Progressive Era. New York: Routledge, 2004.

Browning, Judkin. "Removing the Mask of Nationality: Unionism, Racism, and Federal Military Occupation in North Carolina, 1862-1865, " The Journal of Southern History 71, no. 3 (August 2005): 589-620.

Brundage, W. Fitzhugh. The Southern Past: A Clash of Race and Memory. Cambridge: Harvard University Press, 2005.

Buffington, Daniel Taylor. "A South in the North: Emplacing the South in the American National Myth.” National Identities 13, no. 3 (2011): 235-251.

Bullock, Henry Allen. A History of Negro Education in the South: From 1619 to the Present. Cambridge: Harvard University Press, 1967. 
Burrows, Edwin G. and Mike Wallace. Gotham: A History of New York City to 1898. New York: Oxford Paperbacks, 2000.

Bush, Rod. We Are Not What We Seem: Black Nationalism and Class Struggle in the American Century. New York: New York University Press, 1999.

Bynum, Tara. “'One Important Witness': Remembering Lydia Brown in Thomas Dixon's The Clansman," Texas Studies in Literature and Language 52, no. 3 (Fall 2010): 247-265.

Bynum, Victoria. The Long Shadow of the Civil War: Southern Dissent and Its Legacies. Chapel Hill: University of North Carolina Press, 2010.

Caccavari, Peter Jerome. "Reconstructions of Race and Culture in America: Violence and Knowledge in Works by Albion Tourgée, Charles Chesnutt, and Thomas Dixon, Jr.” PhD diss. Rutgers University, 1993.

Calhoun, Charles W. Conceiving a New Republic: The Republican Party and the Southern Question, 1869-1900. Lawrence: University Press of Kansas, 2006.

Campbell, Ballard S. The Growth of American Government: Governance from the Cleveland Era to the Present. Bloomington: Indiana State University Press, 2015.

Capozzola, Christopher. "Thomas Dixon's War Prayers" in "New Perspectives on 'The War Prayer': An International Forum," edited by Shelley Fisher Fishkin And Takayuki Tatsumi. Twain Studies 2 (2006): 61-65.

- Uncle Sam Wants You: World War I and the Making of the Modern American Citizen. New York: Oxford University Press, 2008.

Carnes, Mark C. and Clyde Griffen, eds. Meanings for Manhood: Construction of Masculinity in Victorian America. Chicago: University of Chicago Press, 1990.

Carroll, Anthony J. Protestant Modernity: Weber, Secularization, and Protestantism. Scranton, Pennsylvania: University of Scranton Press, 2008.

Carter, Everett. "Cultural History Written with Lightning: the Significance of the Birth of a Nation." American Quarterly 12, no. 3 (Autumn 1960): 347-357.

Carter, Dan T. When the War was Over: The Failure of Self-Reconstruction in the South, 1865-1867. Baton Rouge: Louisiana State University Press, 1985.

Cash, W.J. The Mind of the South. New York: A.A. Knopf, 1941. 
Cashdollar, Charles C. The Transformation of Theology, 1830-1890: Positivism and Protestant Thought in Britain and America. Princeton: Princeton University Press, 1989.

Cashman, Sean Dennis. America in the Gilded Age: From the Death of Lincoln to the Rise of Theodore Roosevelt. New York: New York University Press, 1993.

Cassedy, Steven. Connected: How Trains, Genes, Pineapples, Piano Keys, and a Few Disasters Transformed Americans at the Dawn of the Twentieth Century. Stanford: Stanford University Press, 2014.

Chadwick, Bruce. The Reel Civil War: Mythmaking in American Film. New York: Alfred A. Knopf, 2001.

Chakkalakal, Tess and Kenneth W. Warren, eds. Jim Crow, Literature, and the Legacy of Sutton E. Griggs. Athens: University of Georgia Press, 2013.

Chalmers, David M. Hooded Americanism: The History of the Ku Klux Klan, Third ed. Durham: Duke University Press, 1965.

Chandler, Alfred, Jr. Visible Hand: The Managerial Revolution in American Business. Cambridge: Harvard University Press, 1977.

Chapell, Colin B. "The Third Strand: Race, Gender, and Self-Government in the Mind Of Lyman Abbott." Fides et Historia 42, no. 2 (Summer/Fall 2010): 27-54.

Cherny, Robert W. Populism and the Election of 1896. New York: Grossman, 1974.

Cherry, Conrad, ed. God's New Israel: Religious Interpretations of American Destiny. Chapel Hill: University of North Carolina Press, 1998.

Cheshire, Godfrey. "Why No One is Celebrating the $100^{\text {th }}$ Anniversary of the Feature Film." Southern Cultures 21, no. 4 (Winter 2015): 28-37.

Cimbala, Paul A. and Randall Miller, eds. The Great Task Remaining Before Us: Reconstruction as America's Continuing Civil War. New York: Fordham University Press, 2010.

Citron, Danielle Keats. Hate Crimes in Cyberspace. Cambridge: Harvard University Press, 2014.

Clanton, Gene. Congressional Populism and the Crisis of the 1890s. Lawrence: University Press of Kansas, 1998. 
Clerico, David K. "Thomas Dixon, Jr. and the 'Trilogy of Reconstruction'” M.A. Thesis, Southwest Texas State University, 1974.

Cobb, James C. Redefining Southern Culture: Mind and Identity in the Modern South. Athens: University of Georgia Press, 1999.

—. Away Down South: A History of Southern Identity. New York: Oxford University Press, 2005.

Cohen, Nancy. The Reconstruction of American Liberalism, 1865-1914. Chapel Hill: University of North Carolina Press, 2002.

Coleman, Arthur Prudden. Wanderers Twain: Modjeska and Sienkiewicz: A View from California. Cheshire, Connecticut: Cherry Hill Books, 1964.

Coker, Joe L. Liquor in the Land of the Lost Cause: Southern White Evangelicals and the Prohibition Movement. Lexington: University Press of Kentucky, 2007.

Cook, Raymond Allen. Fire from the Flint: the Amazing Careers of Thomas Dixon. Winston-Salem, North Carolina: John F. Blair, 1968.

—. Thomas Dixon. New York: Twayne Publishers, Inc.,1974.

Cooper, John Milton, Jr. Walter Hines Page: The Southerner as American, 1855-1918. Chapel Hill: University of North Carolina Press, 1977.

Cooper, Tova. The Autobiography of Citizenship: Assimilation and Resistance in U.S. Education. New Brunswick: Rutgers University Press, 2014.

Cox, John D. Traveling South: Travel Narratives and the Construction of American Identity. Athens: University of Georgia Press, 2005.

Cox, Karen L. Dixie's Daughters: the United Daughters of the Confederacy and the Preservation of Confederate Culture. Gainesville: University Press of Florida, 2003.

- Dreaming of Dixie: How the South was Created in American Popular Culture. Chapel Hill: University of North Carolina Press, 2011.

Clemens, Elisabeth S. The People's Lobby: Organizational Innovation and the Rise of Interest Group Politics in the United States, 1890-1925. Chicago: University of Chicago Press, 1997.

Collins, Ann V. All Hell Broke Loose: American Race Riots from the Progressive Era through World War II. Santa Barbara: Praeger, 2012. 
Creech, Joe. Righteous Indignation: Religion and the Populist Revolution. Urbana: University of Illinois Press, 2006

Cripps, Thomas. Slow Fade to Black: The Negro in American Film, 1900-1942. New York: Oxford University Press, 1977.

Cunningham, Raymond J. "Is History Past Politics? Herbert Baxter Adams as a Precursor of 'The New History."” The History Teacher 9, no. 2 (February 1976): 244-257.

—. "The German Historical World of Herbert Baxter Adams: 1874-1876." The Journal of American History 68, no. 2 (September 1981): 261-275.

Currarino, Rosanne. "The Politics of 'More': The Labor Question and the Idea of Economic Liberty in Industrial America." The Journal of American History, no. 1 (June 2006): 17-36.

- The Labor Question in America: Economic Democracy in the Gilded Age. Urbana: University of Illinois Press, 2011.

Current, Richard Nelson. Northernizing the South. Athens: University Press of Georgia, 1983.

—. Those Terrible Carpetbaggers. New York: Oxford University Press, 1988.

Curtis, Susan. A Consuming Faith: The Social Gospel and Modern American Culture. Baltimore: Johns Hopkins University Press, 1991.

Dailey, Jane, Glenda Elizabeth Gilmore, and Bryant Simone, eds. Jumpin' Jim Crow: Southern Politics from Civil War to Civil Rights. Princeton: Princeton University Press, 2000.

Daniels, Roger. Guarding the Golden Door: American Immigration Policy and Immigrants Since 1882. New York: Hill and Wang, 2004.

Davenport, F. Garvin. The Myth of Southern History: Historical Consciousness in Twentieth-Century Southern Literature. Nashville: Vanderbilt University Press, 1970.

- "Thomas Dixon's Mythology of Southern History." Journal of Southern History 36, no. 3 (August 1970): 350-367.

Davis, Hugh. "We Will Be Satisfied With Nothing Less": The African American Struggle for Equal Rights in the North During Reconstruction. Ithaca: Cornell University Press, 2011. 
Davis, William C. The Cause Lost: Myths and Realities of the Confederacy. Lawrence: University Press of Kansas, 1996.

Dawley, Alan. Struggles for Justice: Social Responsibility and the Liberal State. Cambridge: Belknap Press, 1991.

- Changing the World: American Progressives in War and Revolution. Princeton: Princeton University Press, 2003.

DeCanio, Samuel. Democracy and the Origins of the American Regulatory State. New Haven: Yale University Press, 2015.

Dilts, Andrew. Punishment and Inclusion: Race, Membership, and the Limits of American Liberalism. New York: Fordham University Press, 2014.

Diner, Steven J. A Very Different Age: Americans of the Progressive Era. New York: Hill and Wang, 1998.

Donovan, Brian. White Slave Crusades: Race, Gender, and Anti-vice Activism, 18871917. Urbana: University of Illinois Press, 2006.

Dorrien, Gary. Economy, Difference, Empire: Social Ethics for Social Justice. New York: Columbia University Press, 2010.

Dorsey, Leroy G. We Are All Americans, Pure and Simple: Theodore Roosevelt and the Myth of Americanism. Tuscaloosa: University of Alabama Press, 2007.

Dossett, Kate. Bridging Racial Divides: Black Nationalism, Feminism, and Integration in the United States, 1896-1935. Gainesville: University Press of Florida, 2008.

Downs, Gregory P. Declarations of Dependence: The Long Reconstruction of Popular Politics in the South, 1861-1908. Chapel Hill: University of North Carolina Press, 2011.

Drass, Kriss A. and Edgar Kiser, "Structural Roots of Visions of the Future: WorldSystem Crisis and Stability and the Production of Utopian Literature in the United States, 1883-1975." International Studies Quarterly 32, no. 4 (December 1988): 421-438.

Driskell, Jay Winston, Jr. Schooling Jim Crow: The Fight for Atlanta's Booker T. Washington High School and the Roots of Black Protest Politics. Richmond: University of Virginia Press, 2014. 
Duck, Leigh Anne. The Nation's Region: Southern Modernism, Segregation, and U.S. Nationalism. Athens: University of Georgia Press, 2006.

Dubofsky, Melvyn. The State and Labor in Modern America. Chapel Hill: University of North Carolina Press, 1994.

Dudden, Faye E. Fighting Chance: The Struggle over Woman Suffrage and Black Suffrage in Reconstruction America. New York: Oxford University Press, 2011.

Durden, Robert F. "The 'Cow-Bird' Grounded: The Populist Nomination of Bryan and Tom Watson in 1896." The Mississippi Valley Historical Review 50, no. 3 (December 1963): 397-423.

- The Climax of Populism: The Election of 1896. Lexington: University of Kentucky Press, 1965.

Durrill, Wayne K. "Political Legitimacy and Local Courts: 'Politicks at Such a Rage' in a Southern Community during Reconstruction." The Journal of Southern History 70, no. 3 (August 2004): 577-602.

DuRocher, Kristina. Raising Racists: The Socialization of White Children in the Jim Crow South. Lexington: University Press of Kentucky, 2011.

Eby, Clare. "Slouching Toward Beastliness: Richard Wright's Anatomy of Thomas Dixon." African American Review 35, no. 3 (Autumn 2001): 439-458.

Edwards, Laura F. Gendered Strife and Confusion: The Political Culture of Reconstruction. Urbana: University of Illinois Press, 1997.

—_. "Southern History as U.S. History." Journal of Southern History 75 (August 2009): 1-32.

- A Legal History of the Civil War and Reconstruction: A Nation of Rights. Cambridge: Cambridge University Press, 2015.

Edwards, Rebecca. Angels in the Machinery: Gender and American Party Politics from the Civil War to the Progressive Era. New York: Oxford University Press, 1997.

- New Spirits: Americans in the Gilded Age, 1865-1905. New York: Oxford University Press, 2006.

Egbert, Donald Drew and Stow Persons. Socialism in American Life, Vol. 1. Princeton: Princeton University Press, 1952. 
Egerton, Douglas R. The Wars of Reconstruction: The Brief, Violent History of America's Most Progressive Era. New York: Bloomsbury Press, 2014.

Eisenach, Eldon J. The Lost Promise of Progressivism. Lawrence: University Press of Kansas, 1994.

Emberton, Carole. Beyond Redemption, Race, Violence, and the American South after the Civil War. Chicago: University of Chicago Press, 2013.

Eliot, Mark. Colorblind Justice: Albion Tourgée and the Quest for Racial Equality From the Civil War to Plessy vs. Ferguson. New York: Oxford University Press, 2006.

Emirbayer, Mustafa. "Beyond Structuralism and Voluntarism: The Politics and Discourse of Progressive School Reform, 1890-1930." Theory and Society 21, no. 5 (October 1992): 621-664.

Ernst, Daniel R. Toqueville's Nightmare: The Administrative State Emerges in America, 1900-1940. New York: Oxford University Press, 2014.

Escott, Paul D. Many Excellent People: Power and Privilege in North Carolina, 18501900. Chapel Hill: University of North Carolina Press, 1988.

- North Carolinians in the Era of the Civil War and Reconstruction. Chapel Hill: University of North Carolina Press, 2008.

Evans, William McKee. Ballots and Fence Rails: Reconstruction on the Lower Cape Fear. Chapel Hill: University of North Carolina Press, 1967.

Dabi, M. Giulia. "Desegregating the Future: Sutton E. Griggs' Pointing the Way and American Utopian Fiction in the Age of Jim Crow." American Literary Realism 44, no. 2 (Winter 2012): 113-132.

Fahs, Alice and Joan Waugh, eds. The Memory of the Civil War in American Culture. Chapel Hill: University of North Carolina, 2004.

Fairfield, John D. The Public and Its Possibilities: Triumphs and Tragedies in the American City. Philadelphia: Temple University Press, 2010.

Fallace, Thomas. "Recapitulation Theory and the New Education: Race, Culture, Imperialism, and Pedagogy, 1894-1916." Curriculum Inquiry 42, no. 4 (2012): $510-533$.

Farrar-Myers, Victoria A. and Justin S. Vaughan, eds. Controlling the Message: New Media in American Political Campaigns. New York: New York University Press, 2015. 
Feimster, Crystal N. Southern Horrors: Women and the Politics of Rape and Lynching. Cambridge: Harvard University Press, 2011.

Fenton, Elizabeth A. Religious Liberties: Anti-Catholicism and Liberal Democracy in Nineteenth-Century U.S. Literature and Culture. New York: Oxford University Press, 2011.

Fessenden, Tracy. Culture and Redemption: Religion, the Secular, and American Literature. Princeton: Princeton University Press, 2007.

Fink, Leon. Workingmen's Democracy: The Knights of Labor and American Politics. Urbana: University of Illinois Press, 1985.

_. Progressive Intellectuals and the Dilemmas of Democratic Commitment. Cambridge: Harvard University Press, 1997.

- The Long Gilded Age: American Capitalism and the Lesson of a New World Order. Philadelphia: University of Pennsylvania Press, 2015.

Flanagan, Maureen A. America Reformed: Progressivism and Progressivisms, 1890s1920s. New York: Oxford University Press, 2007.

Flood, Gerald Joseph. "Herbert Baxter Adams and the Study of Education," Ph.D. Dissertation. Johns Hopkins University, 1970.

Fogarty, Robert S. All Things New: American Communes and Utopian Movements, 1860-1914. Chicago: University of Chicago Press, 1990.

Foner, Eric. Reconstruction: America's Unfinished Revolution, 1863-1877. New York: Harper and Row, 1988.

- Nothing But Freedom: Emancipation and Its Legacy. Baton Rouge: Louisiana State University Press, 1993.

- "Who is An American? The Imagined Community in American History." The Centennial Review 41, no. 3 (Fall 1997): 425-438.

Foner, Eric and Lisa McGirr, eds. American History Now. Philadelphia: Temple University Press, 2011.

Foster, Gaines M. Ghosts of the Confederacy: Defeat, the Lost Cause, and the Emergence of the New South, 1865 to 1913. New York: Oxford University Press, 1987. 
Fox, Richard Wrightman. "The Culture of Liberal Protestant Progressivism, 1875-1925." The Journal of Interdisciplinary History 23, no. 3 (Winter 1993): 639-660.

Foy, Joseph J. and Timothy M. Dale, eds. Homer Simpson Ponders Politics: Popular Culture as Political Theory. Lexington: University Press of Kentucky, 2013.

Franklin, John Hope. Reconstruction: After the Civil War. Chicago: University of Chicago Press, 1961.

__. "Birth of a Nation': Propaganda as History." The Massachusetts Review 20, no. 3 (Autumn 1979): 417-434.

Frantzen, Allen J. and John D. Niles, eds. Anglo-Saxonism and the Construction of Social Identity. Gainesville: University Press of Florida, 1997.

Frederick, Peter J. Knights of the Golden Rule: The Intellectual as Social Reformer in the 1890s. Lexington: University Press of Kentucky, 1976.

Frederickson, George M. The Black Image in the White Mind: The Debate on AfroAmerican Character and Destiny, 1817-1914. New York: Harper and Row, 1971.

Frey, Donald E. "Francis Wayland's 1830s Textbooks: Evangelical Ethics and Political Economy," The Journal of the History of Economic Thought 24, no. 2 (June 2002): 215-231.

Frost, David. Thinking Confederates: Academia and the Idea of Progress in the New South. Knoxville: University of Tennessee Press, 2000.

Frezza, Daria. The Leader and the Crowd: Democracy in American Public Discourse, 1880-1941. Athens: University of Georgia Press, 2007.

Fries, "Staatstheorie and the New American Science of Politics," Journal of the History of Ideas 34, no. 3 (July-September 1973): 391-404.

Furner, Mary. Advocacy and Objectivity: A Crisis in the Professionalization of American Social Science, 1865-1900. Lexington: University Press of Kentucky, 1975.

Gallagher, Brian. "Racist Ideology and Black Abnormality in The Birth of a Nation." Phylon 43, no. 1 ( $1^{\text {st }}$ Quarter 1982): 68-76.

Gallagher, Gary W. Causes Won, Lost, and Forgotten: How Hollywood and Popular Art Shape What We Known About the Civil War. Chapel Hill: University of North Carolina Press, 2008. 
Gallagher, Gary W. and Alan T. Nolan, eds. The Myth of the Lost Cause and Civil War History. Bloomington: Indiana University Press, 2000.

Gaines, Kevin Kelly. Uplifting the Race: Black Leadership, Politics, and Culture in the Twentieth Century. Chapel Hill: University of North Carolina Press, 1996.

Gaither, Gerald H. Blacks and the Populist Movement: Ballots and Bigotry in the New South. Tuscaloosa: University of Alabama Press, 2006.

Gardner, Martha. The Qualities of a Citizen: Women, Immigration, and Citizenship, 1870-1965. Princeton: Princeton University Press, 2005.

Gass, Walter Conard. "Herbert Baxter Adams and the Development of Historical Instruction in American Colleges and University.” Ed.D. Dissertation. Duke University, 1963.

Gaston, Paul M. The New South Creed: A Study in Southern Mythmaking. New York: Knopf, 1970.

Geiger, Roger L. The History of American Higher Education: Learning and Culture from the Founding to World War II. Princeton: Princeton University Press, 2015.

Gerring, John. Party Ideologies in America, 1828-1996. Cambridge: Cambridge University Press, 2001.

Gerstle, Gary. American Crucible: Race and Nation in the Twentieth Century. Princeton: Princeton University Press, 2001.

Gerster, Patrick and Nicholas Cords, "The Northern Origins of Southern Mythology," The Journal of Southern History 43, no. 4 (November 1977): 567-582.

Gerteis, Joseph. Class and the Color Line: Interracial Class Coalition in the Knights of Labor and the Populist Movement. Durham: Duke University Press, 2007.

Giele, Janet Zollinger. Two Paths to Women's Equality: Temperance, Suffrage, and the Origins of Modern Feminism. New York: Twayne Publishers, 1995.

Gillespie, Michele K. and Randal L. Hall, eds.. Thomas Dixon, Jr. and the Birth of Modern America. Baton Rouge: Louisiana State University Press, 2006.

Gillette, William. Right to Vote: Politics and the Passage of the Fifteenth Amendment. Baltimore: Johns Hopkins University Press, 1965. 
Gilmore, Glenda Elizabeth. Gender and Jim Crow: Women and the Politics of White Supremacy in North Carolina, 1896-1920. Chapel Hill: University of North Carolina Press, 1996.

Gilmore, Glenda Elizabeth and Thomas J. Sugrue. These United States: A Nation in the Making, 1890 to the Present. New York: W.W. Norton \& Company, 2015.

Glad, Paul W. McKinley, Bryan, and the People. Philadelphia: J.B. Lippencott, 1964.

Glenn, Evelyn Nakano. Unequal Freedom: How Race and Gender Shaped American Citizenship and Labor. Cambridge: Harvard University Press, 2002.

Glick, Josh. "Mixed Messages: D.W. Griffith and the Black Press, 1916-1931.” Film History 23, no. 2 (2011): 174-195.

Godshalk, David Fort. Veiled Vision: The 1906 Race Riot and the Reshaping of American Race Relations. Chapel Hill: University of North Carolina Press, 2005.

Goldberg, David J. "Unmasking the Ku Klux Klan: The Northern Movement Against the KKK, 1920-1925." Journal of American Ethnic History 15, no.4 (Summer 1996): $32-48$.

Goldfield, David R. Still Fighting the Civil War: the American South and Southern History. Baton Rouge: Louisiana State University Press, 2002.

Goldstene, Claire. The Struggle for America's Promise: Equal Opportunity at the Dawn Of Corporate Capital. Jackson: University Press of Mississippi, 2014.

Golway, Terry. Machine Made: Tammany Hall and the Creation of Modern American Politics. New York: Liveright, 2014.

Goodwyn, Lawrence. Democratic Promise: The Populist Moment in America. New York: Oxford University Press, 1976.

Gorrell, Donald K. The Age of Social Responsibility: The Social Gospel in the Progressive Era, 1900-1920. Macon: Mercer University Press, 1988.

Grantham, Dewey W. The South and the Sectional Image: The Sectional Theme Since Reconstruction. New York: Harper \& Row, 1967.

Greene, Julie. Pure and Simple Politics: The American Federation of Labor and Political Activism, 1881-1917. New York: Cambridge University Press, 1998. 
Greeson, Jennifer Rae. Our South: Geographic Fantasy and the Rise of National Literature. Cambridge: Harvard University Press, 2010.

Gregory, James N. The Southern Diaspora: How the Great Migrations of Black and White Southerners Transformed America. Chapel Hill: University of North Carolina Press, 2005.

Gross, Thomas L. "The Negro in the Literature of Reconstruction," Phylon 22, no. 1 (1961): 5-14.

Grossman, Lawrence. The Democratic Party and the Negro: Northern and National Politics, 1868-1892. Urbana: University of Illinois Press, 1976.

Gunning, Sandra. Race, Rape, and Lynching: the Red Record of American Literature, 1890-1912. New York: Oxford University Press, 1996.

Gunning, Tom. D.W. Griffith and the Origins of American Narrative Film: The Early Years at Biograph. Urbana: University of Illinois Press, 1991

Guralnick, Stanley M. "Sources of Misconception on the Role of Science in the Nineteenth Century American College," Isis 65, no. 3 (September 1974): 352366.

Guterl, Matthew Pratt. "The New Race Consciousness: Race, Nation, and Empire in American Culture, 1910-1925," Journal of World History 10, no. 2 (Fall 1999): 307-352.

Gyory, Andrew. Closing the Gate: Race, Politics, and the Chinese Exclusion Act. Chapel Hill: University of North Carolina Press, 1998.

Ha, Nathan Q. "The Riddle of Sex: Biological Theories of Sex Difference in the Early Twentieth Century." Journal of the History of Biology 44, no. 3 (Fall 2011): 505546.

Hahn, Steven. The Roots of Southern Populism: Yeoman Farmers and the Transformation of the Georgia Upcountry, 1850-1890. New York: Oxford University Press, 1983.

- A Nation Under Our Feet: Black Political Struggles in the Rural South from Slavery to the Great Migration. Cambridge: Harvard University Press, 2003.

Hale, Grace Elizabeth. Making Whiteness: the Culture of Segregation in theSouth, 18901940. New York: Pantheon Books, 1998. 
Haley, Sarah. No Mercy Here: Gender, Punishment, and the Making of Jim Crow Modernity. Chapel Hill: University of North Carolina Press, 2016.

Hamlin, Kimberly A. From Eve to Evolution: Darwin, Science, and Women's Rights in Gilded Age America. Chicago: University of Chicago Press, 2014.

Hammond, Michael. "'A Soul Stirring Appeal to Every Briton': The Reception of 'The Birth of a Nation' in Britain, 1915-1916." Film History 11, no. 3 (1999): 353-370.

Handy, Robert T. Undermined Establishment: Church-State Relations in America, 18801920. Princeton: Princeton University Press, 1991.

Hansen, Jonathan M. The Lost Promise of Patriotism: Debating American Identity, 1890-1920. Chicago: University of Chicago Press, 2003.

Harkins, Anthony. Hillbilly: A Cultural History of an American Icon. New York: Oxford University Press, 2004.

Harlan, Louis R., Jr. "The Southern Education Board and the Race Issue in Public Education." The Journal of Southern History 23, no. 2 (May 1957): 189-202.

- Separate and Unequal: Public School Campaigns and Racism in the Southern Seaboard States, 1901-1915. Chapel Hill: University of North Carolina Press, 1958.

Harper, Keith. The Quality of Mercy: Southern Baptists and Social Christianity, 18901920. Tuscaloosa: University of Alabama Press, 1996.

Harris, Max F. “The Ideas of Thomas Dixon on Race Relations.” Master's thesis. University of North Carolina, 1948.

Harris, Susan K. God's Arbiters: Americans and the Philippines, 1898-1902. New York: Oxford University Press, 2011.

Harrison, Robert. Congress, Progressive Reform, and the New American State. New York: Cambridge University Press, 2004.

Hasen, Richard L. The Voting Wars: From Florida 2000 to the Next Election Meltdown. New Haven: Yale University Press, 2012.

Haskell, Thomas L. The Emergence of Professional Social Science: The American Social Science Association and the Nineteenth-Century Crisis of Authority. Urbana: University of Illinois Press, 1977. 
- The Authority of Experts: Studies in History and Theory. Bloomington: Indiana University Press, 1984.

Hawkins, Mike. Social Darwinism in European and American Thought, 1860-1945: Nature as Model and Nature as Threat. Cambridge: Cambridge University Press, 1997.

Haynes, Carolyn A. Divine Destiny: Gender and Race in Nineteenth-Century Protestantism. Jackson: University of Mississippi Press, 1998.

Healy, David. U.S. Expansionism: The Imperialist Urge in the 1890s. Madison: University of Wisconsin Press, 1963.

Heilmann, Ann and Margaret Beetham, eds. New Woman Hybridities: Femininity, Feminism, and International Consumer Culture, 1880-1930. New York, Routledge, 2004

Heller, Adele and Lois Palken Rudnick, eds. 1915, the Cultural Moment: the New Politics, the New Woman, the New Psychology, the New Art, and the New Theatre in America. New Brunswick: Rutgers University Press, 1991.

Henderson, Robert M. D.W. Griffith: His Life and Work. New York: Oxford University Press, 1972.

Herbst, Jurgen. The German Historical School in American Scholarship: A Study in the Transfer of Culture. Ithaca: Cornell University Press, 1965.

Heydt, Colin. "Hutcheson's 'Short Introduction' and the Purposes of Moral Philosophy." History of Philosophy Quarterly 26, no. 3 (July 2009): 293-309.

Higham, John. Strangers in the Land: Patterns of American Nativism, 1860-1925. New Brunswick: Rutgers University Press, 1955.

—. "Herbert Baxter Adams and the Study of Local History." The American Historical Review 89, no. 5 (December 1984): 1225-1239.

Hild, Matthew. Greenbackers, Knights of Labor, and Populists: Farmer-Labor Insurgency in the Late-Nineteenth Century. Athens: University of Georgia Press, 2007.

Hilfrich, Fabian. Debating American Exceptionalism: Empire and Democracy in the Wake of the Spanish-American War. New York: Palgrave Macmillan, 2012. 
Hodes, Martha. "The Sexualization of Reconstruction Politics: White Women and Black Men in the South After the Civil War." Journal of the History of Sexuality 3, no. 3 (January 1993): 402-417.

Hoffman, Elizabeth Cobbs. American Umpire. Cambridge: Harvard University Press, 2013.

Hoffman, M. Curtis. "Paradigm Lost: Public Administration at Johns Hopkins University, 1884-96." Public Administration Review 62, no. 1 (January-February 2002): 12-23.

Hofstadter, Richard. Social Darwinism in American Thought. Philadelphia: University of Pennsylvania Press, 1944.

—. The Age of Reform: From Bryan to F.D.R. New York: Knopf, 1955.

Hoganson, Kristen L. Fighting for American Manhood: How Gender Politics Provoked the Spanish-American and Philippine-American Wars. New Haven: Yale University Press, 1998.

Hollinger, David. After Cloven Tongues of Fire: Protestant Liberalism in Modern American History. Princeton: Princeton University Press, 2013.

Holmgren, Beth. Starring Madame Modjeska: On Tour in Poland and America. Indianapolis: Indiana University Press, 2012.

Hopkins, Charles Howard. The Rise of the Social Gospel in American Protestantism, 1865-1915. New Haven: Yale University Press, 1940.

Horn, Stanley F. Invisible Empire: The Story of the Ku Klux Klan, 1866-1871. Boston: Houghton Mifflin Co., 1939.

Horsman, Reginald. Race and Manifest Destiny: The Origins of American Racial AngloSaxonism. Cambridge: Harvard University Press, 1981.

Horton, Carol A. Race and the Making of American Liberalism. New York: Oxford University Press, 2005.

Houghton, Jonathan Thomas Young. "The North Carolina Republican Party: From Reconstruction to the Radical Right." Ph.D. Dissertation. University of North Carolina, 1993.

Hounshell, David. From the American System to Mass Production, 1800-1932. Baltimore: Johns Hopkins University Press, 1985. 
Hudson, Winthrop. "Protestant Clergy Debate the Nation's Vocation, 1898-1899." Church History 42, no. 1 (March 1973): 110-118.

Hume, Richard L. and Jerry B. Gough. Blacks, Carpetbaggers, and Scalawags: The Constitutional Conventions of Radical Reconstruction. Baton Rouge: Louisiana State University Press, 2008.

Inscoe, John C. "'The Clansman' on Stage and Screen: North Carolina Reacts." The North Carolina Historical Review 64, no. 2 (April 1987): 139-161.

Jackson, John P., Jr. and Nadine W. Weldman. John P. Jackson, Jr. and Nadine W. Weidman, "The Origins of Scientific Racism." The Journal of Blacks in Higher Education 50 (Winter 2005/2006): 66-79.

Jackson, Kenneth T. The Ku Klux Klan in the City, 1915-1930. New York: Oxford University Press, 1967.

Jacobson, Matthew Frye. Whiteness of a Different Color: European Immigrants and The Alchemy of Race. Cambridge: Harvard University Press, 1999.

- Barbarian Virtues: the United States Encounters Foreign Peoples at Home and Abroad, 1876-1917. New York: Hill and Wang, 2000.

Janney, Caroline E. Remembering the Civil War: Reunion and the Limits of Reconciliation. Chapel Hill: University of North Carolina Press, 2013.

Jansson, David R. "Internal Orientalism in America: W.J. Cash's The Mind of the South and the Spatial Construction of American National Identity." Political Geography 22 (March 2003): 293-316.

—. "American Hegemony and the Irony of C. Vann Woodward's 'The Irony of Southern History." Southeastern Geography 44 (May 2004): 90-114.

- "The Haunting of the South: American Geopolitical Identity and the Burden of Southern History.” Geopolitics 12 (July 2007): 401-425.

Jarrett, Gene Andrew. Representing the Race: A New Political History of African American Literature. New York: New York University Press, 2011.

Jeffrey-Jones, Rhodri. The American Left and Its Impact on Politics and Society Since 1900. Edinburgh: Edinburgh University Press, 2013.

Johnson-DeBaufre, Melanie, Catherine Keller, and Elias Ortega-Aponte, eds. Common Goods: Economy, Ecology, and Political Theology. New York City: Fordham University, 2015. 
Johnson, Val. “'The Moral Aspects of Complex Problems': New York City Electoral Campaigns Against Vice and the Incorporation of Immigrants, 1890-1901.” Journal of American Ethnic History 25, no. 2/3 (Spring 2006): 74-106.

Jonas, Gilbert. Freedom's Sword: The NAACP and the Struggle Against Racism in America, 1909-1969. New York: Routledge, 2005.

Jones, Jeannette Eileen. In Search of Brightest Africa: Reimagining the Dark Continent in American Culture, 1884-1936. Athens: University of Georgia Press, 2010.

Jones, Stanley L. The Presidential Election of 1896. Madison: University of Wisconsin Press, 1964.

Justesen, Benjamin R. "'The Class of '83': Black Watershed in the North Carolina General Assembly." The North Carolina Historical Review 86, no. 3 (July 2009): 282-308.

Kachun, Mitch. "'Big Jim' Parker and the Assassination of William McKinley: Patriotism, Nativism, Anarchism, and the Struggle for African American Citizenship." Journal of the Gilded Age and Progressive Era 9, no. 1 (January 2010): 93-116.

Kammen, Michael. "The American Past Politicized: The Uses and Misuses of History." Annals of the American Academy of Political and Social Science 617 (May 2008): 42-57.

Kantrowitz, Stephen. Ben Tillman and the Reconstruction of White Supremacy. Chapel Hill: University of North Carolina Press, 2000.

- More Than Freedom: Fighting for Black Citizenship in a White Republic, 18291889. New York: Penguin, 2012.

Kaplan, Amy. The Anarchy of Empire in the Making of U.S. Culture. Cambridge: Harvard University Press, 2002.

Kaplan, Amy. “The Birth of an Empire.” PMLA 114, no. 5 (October 1999): 1068-1079.

Kaufmann, Eric P. The Rise and Fall of Anglo-America. Cambridge: Harvard University Press, 2004.

Kazin, Michael. The Populist Persuasion: An American History. New York: Basic Books, 1995. 
Kazin, Michael and Joseph A. McCartin, eds. Americanism: New Perspectives on the History of an Ideal. Chapel Hill: University of North Carolina Press, 2012.

Keire, Mara L. For Business \& Pleasure: Red Light Districts and the Regulation of Vice in the United States, 1890-1933. Baltimore: Johns Hopkins University Press, 2010.

Kelly, Patrick J. "The Election of 1896 and the Restructuring of Civil War Memory." Civil War History 49, no. 3 (September 2003): 254-180.

Kennedy-Nolle, Sharon D. Writing Reconstruction: Race, Gender, and Citizenship in the Postwar South. Chapel Hill: University of North Carolina Press, 2015.

Kenzer, Robert C. "The Black Businessman in the Postwar South: North Carolina, 18651880.” The Business History Review 63, no. 1 (Spring 1989): 61-87.

Keyssar, Alexander. The Right to Vote: The Contested History of Democracy in the United States. New York: Basic Books, 2000.

Kimmel, Michael S. "Men's Responses to Feminism at the Turn of the Century." Gender and Society 1, no. 3 (September 1987): 261-283.

King, Desmond. Separate and Unequal: Black Americans and the U.S. Federal Government. New York: Clarendon Press of Oxford University Press, 1995.

- Making Americans: Immigration, Race, and the Origins of the Diverse Democracy. Cambridge: Harvard University Press, 2000.

King, Desmond and Stephen G.N. Tuck. "De-centering the South: America's Nationwide White Supremacist Order After Reconstruction.” Past \& Present 194 (February 2007): 213-154.

Kinney, James. "The Rhetoric of Racism: Thomas Dixon and the 'Damned Black Beast'." American Literary Realism, 1870-1910 15, no. 2 (Autumn 1982): 145154.

Kitch, Sally. The Specter of Sex: Gendered Foundations of Racial Formation in the United States. Albany: State University of New York Press, 2009.

Kline, Wendy. Building a Better Race: Gender, Sexuality, and Eugenics from the Turn of the Century to the Baby Boom. Berkeley: University of California Press, 2005.

Kloppenberg, James T. Uncertain Victory: Social Democracy and Progressivism in European and American Thought, 1870-1920. New York: Oxford University Press, 1996. 
Kolchin, Peter. A Sphinx on the American Land: The Nineteenth-Century South in Comparative Perspective. Baton Rouge: Louisiana State University Press, 2003.

Kolko, Gabriel. The Triumph of Conservatism, 1900-1916. New York: Free Press of Glencoe, 1963.

Kornbluh, Mark Lawrence. Why America Stopped Voting: The Decline of Participatory Democracy and the Emergence of Modern American Politics. New York: New York University Press, 1999.

Kornweibel, Theodore. "Seeing Red:” Federal Campaigns Against Black Militancy, 1919-1925. Indianapolis: Indiana University Press, 1998.

Kramer, Jacob. The New Freedom and the Radicals: Woodrow Wilson, Progressive Views of Radicalism, and the Origins of Repressive Tolerance. Philadelphia: Temple University Press, 2015.

Kramer, Paul A. "Empires, Exceptions, and Anglo-Saxons: Race and Rule Between The British and the United States Empires, 1880-1910." The Journal of American History 88, no. 4 (March 2002): 1315-1353.

- The Blood of Government: Race, Empire, the United States, and the Philippines. Chapel Hill: University of North Carolina Press, 2006.

Kreyling, Michael. Inventing Southern Literature. Jackson: University Press of Mississippi, 1998.

__. "Toward 'A New Southern Studies'," South Central Review 22, no. 1 (Spring 2005): 4-18.

Laats, Adam. "Red Schoolhouse, Burning Cross: The Ku Klux Klan of the 1920s and Educational Reform." History of Education Quarterly 52, no. 3 (August 2012): 323-350.

Labode, Modupe. ''Defend Your Manhood and Womanhood Rights': The Birth of a Nation, Race, and the Politics of Respectability in Early-Twentieth Century Denver, Colorado." Pacific Historical Review 84, no. 2 (May 2015): 163-194.

LaFeber, Walter. The New Empire: an Interpretation of American Expansion, 18601898. Ithaca: Cornell University Press, 1963.

Landes, Richard Allen. Heaven on Earth: The Varieties of the Millennial Experience. New York: Oxford University Press, 2011. 
Lang, Robert, ed. The Birth of a Nation: D.W. Griffith, Director. New Brunswick: Rutgers University Press, 1994.

Larson, Edward J. Sex, Race, and Science: Eugenics in the Deep South. Baltimore: Johns Hopkins University Press, 1995.

Lears, Jackson. No Place of Grace: Antimodernism and the Transformation of American Culture, 1880-1920. New York: Pantheon Books, 1981.

- Rebirth of a Nation: The Making of Modern America, 1877-1920. New York: Harper Collins Books, 2009.

Lehr, Dick. The Birth of a Nation: How a Legendary Filmmaker and a Crusading Editor Reignited America's Civil War. New York: PublicAffairs, a member of Perseus Books, 2014.

Lemire, Elise. "Miscegenation": Making Race in America. Philadelphia: University of Pennsylvania Press, 2002.

Lemoreaux, Naomi R. The Great Merger Movement in American Business, 1895-1904. Cambridge: Cambridge University Press, 1988.

Lennig, Arthur. "Myth and Fact: The Reception of 'The Birth of a Nation'." Film History 16, no. 2 (2004): 117-141.

Leonard, Thomas C. "Religion and Evolution in Progressive Era Political Economy: Adversaries or Allies?" History of Political Economy 43, no. 3 (2011): 429-469.

- Illiberal Reformers: Race, Eugenics, and American Economics in the Progressive Era. Princeton: Princeton University Press, 2016.

Leslie, William Bruce. Gentlemen and Scholars: College and Community in the Age of the University.' University Park: Pennsylvania University Press, 1992.

Levy, Jonathan. Freaks of Fortune: The Emergence of Capitalism and Risk in America. Cambridge: Harvard University Press, 2012.

Licht, Walter. Industrializing America: The Nineteenth Century. Baltimore: Johns Hopkins University Press, 1995.

Lieberson, Stanley. A Pie of the Pie: Blacks and White Immigrants Since 1880. Berkeley: University of California Press, 1981.

Link, William A. "Making the Inarticulate Speak: A Reassessment of Public Education in the Rural South, 1870-1920." Journal of Thought 18, no. 3 (Fall 1983): 63-75. 
- The Paradox of Southern Progressivism, 1880-1930. Chapel Hill: University of North Carolina Press, 1992.

Livingstone, David N. "Science and Society: Nathaniel S. Shaler and Racial Ideology." Transactions of the Institute of British Geographers 9, no. 2 (1984): 181-210.

—. Darwin's Forgotten Defenders: The Encounter Between Evangelical Theology and Evolutionary Thought. Grand Rapids, Michigan: W.B. Eerdmams, 1987.

- Dealing With Darwin: Place, Politics, and Rhetoric in Religious Engagements With Evolution. Baltimore: Johns Hopkins University Press, 2014.

Love, Eric Tyrone Lowery. Race Over Empire: Racism and U.S. Imperialism, 18961900. Chapel Hill: University of North Carolina Press, 2004.

Luker, Ralph E. The Social Gospel in Black and White: American Racial Reform, 18851912. Chapel Hill: University of North Carolina Press, 1991.

MacLean, Nancy. Behind the Mask of Chivalry: The Making of the Second Ku Klux Klan. New York: Oxford University Press, 1994.

Madden, Edward H. "Francis Wayland and the Limits of Moral Responsibility," Proceedings of the American Philosophical Society 106, no. 4 (August 1962): 348-359.

Magliocca, Gerard N. The Tragedy of William Jennings Bryan: Constitutional Law and the Politics of Backlash. New Haven: Yale University Press, 2011.

Magowan, Kim. 'Coming Between the 'Black Beast' and the White Virgin: The Pressures of Liminality in Thomas Dixon." Studies in American Fiction 27, no. 1 (Spring 1999): 77-102.

Malczewski, Joan. "Weak State, Stronger Schools: Northern Philanthropy and Organizational Change in the Jim Crow South." The Journal of Southern History 75, no. 4 (November 2009): 963-1000.

Maltz, Earl M. Civil Rights, The Constitution, and Congress, 1863-1869. Lawrence: University Press of Kansas, 1990.

Mangun, Kimberley. "'As Citizens of Portland We Must Protest': Beatrice Morrow Cannady and the African American Response to D.W. Griffith's 'Masterpiece'." Georgia Historical Quarterly 107, no. 3 (Fall 2006): 382-409. 
Marotta, Gary. "The Academic Mind and the Rise of U.S. Imperialism: Historians and Economists as Publicists for Ideas of Colonial Expansion." American Journal of Economics and Sociology 42, no. 2 (April 1983): 217-234.

Marquis, Greg. "A War Within a War: Canadian Reactions of D.W. Griffith's The Birth of a Nation." Social History 47, no. 94 (2014): 421-442.

Marriner, Gerald L. "The Feminist Revolt: The Emergence of the New Woman in the Early-Twentieth Century." Humboldt Journal of Social Relations 1, no. 2 (Spring/Summer 1974): 127-134.

Marsden, George M. Fundamentalism in American Culture: The Shaping of TwentiethCentury Evangelicalism, 1870-1925. New York: Oxford University Press, 1980.

- The Soul of the American University: From Protestant Establishment to Established Nonbelief. New York: Oxford University Press, 1994.

Martin, Jeffrey B. "Film Out of Theatre: D.W. Griffith, Birth of a Nation and the Melodrama The Clansman." Literature/Film Quarterly 18, no. 2 (1990): 87-95.

Martin, Scott C. Devil of the Domestic Sphere: Temperance, Gender, and Middle-Class Ideology, 1800-1860. DeKalb: Northern Illinois University Press, 2008.

Masur, Kate. An Example for All the Land: Emancipation and the Struggle over Equality in Washington, D.C. Chapel Hill: University of North Carolina Press, 2010.

Mattson, Kevin. Creating a Democratic Public: The Struggle for Urban Participatory Democracy During the Progressive Era. Philadelphia: Pennsylvania State University Press, 1998.

Maxcy, Spencer J. "The Idea of Consolidation in Southern Education During the Early Decades of the Twentieth Century," Peabody Journal of Education 53, no. 3 (April 1976): 216-222.

Maxwell, Angie. The Indicted South: Public Criticism, Southern Inferiority, and the Politics of Whiteness. Chapel Hill: University of North Carolina Press, 2014.

Mayer, David. Stagestruck Filmmaker: D.W. Griffith and the American Theatre. Iowa City: University of Iowa Press, 2009.

McCann, Charles Robert. Order and Control in American Socio-Economic Thought: Social Scientists and Progressive Era Reform. New York: Routledge, 2012. 
McCartney, Paul T. Power and Progress: American National Identity, the War of 1898, and the Rise of American Imperialism. Baton Rouge: Louisiana State University Press, 2006.

McChesney, Robert W. Blowing the Roof off the Twenty-First Century: Media, Politics, and the Struggle for Post-Capitalist Democracy. New York: New York University Press, 2014

McClay, Wilfred M. The Masterless: Self and Society in Modern America. Chapel Hill: University of North Carolina Press, 1994.

McConnaughy, Corrine M. The Woman Suffrage Movement in America: a Reassessment. New York: Cambridge University Press, 2013

McConnell, Roland C. The Negro in North Carolina Since Reconstruction. New York: New York University Press, 1949.

McCoy, Alfred W. and Francisco A. Scarano, eds. Colonial Crucible: Empire in the Making of the Modern American State. Madison: University of Wisconsin Press, 2009.

McCurry, Stephanie. Confederate Reckoning: Power and Politics in the Civil War South. Cambridge: Harvard University Press, 2010.

McGee, Brian R. “Thomas Dixon's The Clansman: Radical, Reactionaries, and the Anticipated Utopia." Southern Communications Journal 65, no. 4 (Summer 2000): 300-317.

McGerr, Michael. Years of Decision: American Politics in the 1890s. New York: Wiley, 1978.

- The Decline of Popular Politics in the American North, 1865-1928. New York: Oxford University Press, 1986.

- A Fierce Discontent: the Rise and Fall of the Progressive Movement in America, 1870-1930. New York: Free Press, 2003.

McLaurin, Melton. "The Knights of Labor in North Carolina Politics." The North Carolina Historical Review 49, no. 3 (July 1972): 298-315.

McKee, Kathryn and Annette Trefzer, eds. Global Contexts, Local Literatures: The New Southern Studies. Durham: Duke University Press, 2006.

McKenna, George. American Populism. New York: Putnam, 1974. 
McKinney, Gordon B. Southern Mountain Republicans, 1865-1900: Politics and the Appalachian Community. Chapel Hill: University of North Carolina Press, 1978.

McMath, Robert C. American Populism: A Social History, 1877-1898. New York: Hill and Wang, 1993.

McPherson, James M. The Struggle for Equality: Abolitionists and the Negro in the Civil War and Reconstruction. Princeton: Princeton University Press, 1965.

McPherson, Tara. Reconstructing Dixie: Race, Gender, and Nostalgia in the Imagined South. Durham: Duke University Press, 2003.

McSeveney, Samuel T. The Politics of Depression: Political Behavior in the Northeast, 1893-1896. New York: Oxford University Press, 1972.

McVeigh, Rory. The Rise of the Ku Klux Klan: Right-Wing Movements and National Politics. Minneapolis: University of Minnesota Press, 2009.

McWilliams, Tennant S. The New South Faces the World: Foreign Affairs and the Southern Sense of Self, 1877-1950. Tuscaloosa: University of Alabama Press, 2007.

Mehrota, Ajay. Making the Modern American Fiscal State: Law, Politics, and the Rise of Progressive Taxation, 1877-1929. New York: Cambridge University Press, 2013.

Meier, August and John H. Bracey, Jr. "The NAACP as a Reform Movement, 19091965: 'To Reach the Conscience of America'." The Journal of Southern History 59, no. 1 (February 1993): 3-30.

Meiser, Jeffrey W. Power and Restraint: The Rise of the United States, 1898-1941. Washington, D.C.: Georgetown University Press, 2015.

Merritt, Russell. "Dixon, Griffith, and the Southern Legend." Cinema Journal 12, no. 1 (Autumn 1972): 26-45.

Michaels, Walter Benn. "Race Into Culture: A Critical Genealogy of Cultural Identity." Critical Inquiry 18, no. 4 (Summer 1992): 655-685.

Miller, Bonnie M. From Liberation to Conquest: The Visual and Popular Cultures of the Spanish-American War of 1898. Boston: University of Massachusetts Press, 2011.

Mislin, David. Saving Faith: Making Religious Pluralism an American Value at the Dawn of the Secular Age. Ithaca: Cornell University Press, 2015. 
Mizruchi, Susan L. The Rise of Multicultural America: Economy and Print Culture, 1865-1915. Chapel Hill: University of North Carolina Press, 2008.

Mitchell, Douglas L. A Disturbing and Alien Memory: Southern Novelists Writing History. Baton Rouge: Louisiana State University Press, 2008.

Mitchell, Michele. Righteous Propagation: African Americans and the Politics of Racial Destiny after Reconstruction. Chapel Hill: University of North Carolina Press, 2004.

Moore, James R. The Post-Darwinian Controversies: A Study of the Protestant Struggles to Come to Terms with Darwin in Great Britain and America, 1870-1900. New York: Cambridge University Press, 1979.

Moorhead, James H. World Without End: Mainstream American Protestant Visions of the Last Things, 1880-1925. Bloomington: Indiana University Press, 1999.

Moreau, Joseph. Schoolbook Nation: Conflicts Over American History Textbooks from the Civil War to the Present. Ann Arbor: University of Michigan Press, 2004.

Moreno, Paul D. The American State from the Civil War to the New Deal: The Twilight of Constitutionalism and the Triumph of Progressivism. Cambridge: Cambridge University Press, 2013.

Moreno, Paul D. and Johnathan O'Neill, eds. Constitutionalism in the Approach and Aftermath of the Civil War. New York: Fordham University Press, 2013.

Morgan, Francesca. Women and Patriotism in Jim Crow America. Chapel Hill: University of North Carolina Press, 2005.

Muhammad, Khalil Gibran. The Condemnation of Blackness: Race, Crime and the Making of Modern Urban America. Cambridge: Harvard University Press, 2010.

Muncy, Robyn. "Trustbusting and White Manhood in America, 1898-1914." American Studies 38, no. 3 (Fall 1997): 21-42.

Murdock, Catherine Gilbert. Domesticating Drink: Women, Men, and Alcohol in America, 1870-1940. Baltimore: Johns Hopkins University Press, 1998.

Murphy, Gretchen. Shadowing the White Man's Burden: U.S. Imperialism and the Problem of the Color Line. New York: New York University Press, 2010.

Murphy, Kevin P. Political Manhood: Red Bloods, Mollycoddles, and the Politics of Progressive Era Reform. New York: Columbia University Press, 2008. 
Mushrat, Jerome. Tammany: The Evolution of a Political Machine, 1789-1865.

Syracuse: Syracuse University Press, 1971.

Myers, Peter C. Frederick Douglass: Race and the Rebirth of American Liberalism. Lawrence: University Press of Kansas, 2008.

Nackenoff, Carol and Julie Novkov, eds. Statebuilding From the Outside In: Between Reconstruction and the New Deal. Philadelphia: University of Pennsylvania Press, 2014.

Nagel, Jack H. and Rogers M. Smith, eds. Representation: Elections and Beyond. Philadelphia: University of Pennsylvania Press, 2013

Nelson, Scott Reynolds. Iron Confederacies: Southern Railways, Klan Violence, and Reconstruction. Chapel Hill: University of North Carolina Press, 1999.

Ngai, Mae M. Impossible Subjects: Illegal Aliens and the Making of Modern America. Princeton: Princeton University Press, 2005.

Noll, Mark A. God and Race in American Politics: A Short History. Princeton: Princeton University Press, 2008.

Numbers, Ronald L. Darwinism Comes to America. Cambridge: Harvard University Press, 1998.

Nye, David E. Electrifying America: Social Meaning of a New Technology, 1880-1940. Cambridge: MIT Press, 1990.

Oakes, Frances. "Whitman and Dixon: A Strange Case of Borrowing." The Georgia Review 11, no. 3 (Fall 1957): 333-340

O’Brien, Michael. The Idea of the American South, 1920-1941. Baltimore: Johns Hopkins University Press, 1979.

Ochieng' Nyongó, Tavia Amolo. The Amalgamation Waltz: Race, Performance and the Ruses of Memory. Minneapolis: University of Minnesota Press, 2009.

Okuda, Akiyo Ito. 'A Nation is Born': Thomas Dixon's Vision of White Nationhood and His Northern Supporters." The Journal of American Culture 32, no. 3 (September 2009): 214-231.

Oliver, Lawrence J. "Writing from the Right during the 'Red Decade': Thomas Dixon's Attack on W.E.B. DuBois and James Weldon Johnson in The Flaming Sword," American Literature 70, no. 1 (March 1998): 131-152. 
Olsen, Otto H. "The Ku Klux Klan: A Study in Reconstruction Politics and Propaganda." The North Carolina Historical Review 39, no. 3 (July 1962): 340-362.

Olund, Eric. "Geography Written in Lightning: Race, Sexuality, and Regulatory Aesthetics in The Birth of a Nation." Annals of the Association of American Geographers 103, no. 4 (2013): 925-943.

Ostrander, Richard. The Life of Prayer in a World of Science: Protestants, Prayer, and American Culture, 1870-1930. New York: Oxford University Press, 2000.

Paschal, George Washington. History of Wake Forest College Vol. II, 1865-1905. Wake Forest, North Carolina: Wake Forest College, 1943.

Painter, Nell Irvin. Standing at Armageddon: The United States, 1877-1919. New York: W.W. Norton, 1987.

—. The History of White People. New York: W.W. Norton, 2010.

Parker, Alison M. Purifying America: Women, Cultural Reform, and Pro-Censorship Activism, 1873-1933. Urbana: University of Illinois Press, 1997.

Parsons, Elaine Frantz. "Midnight Rangers: Costume and Performance in the Reconstruction-Era Ku Klux Klan.” The Journal of American History 92, no. 3 (December 2005): 811-836.

- Ku-Klux: The Birth of the Klan During Reconstruction. Chapel Hill: University of North Carolina Press, 2015.

Pascoe, Peggy. What Comes Naturally: Miscegenation Law and the Making of Race in America. New York: Oxford University Press, 2009.

Paulin, Diana Rebekkah. Imperfect Unions: Staging Miscegenation in U.S. Drama and Fiction. Minneapolis: University of Minnesota Press, 2012.

Perman, Michael. Struggle for Mastery: Disfranchisement in the South, 1888-1908. Chapel Hill: University of North Carolina Press, 2001.

- The Road to Redemption: Southern Politics, 1869-1879. Chapel Hill: University of North Carolina Press, 1984.

Perrow, Charles. Organizing America: Wealth, Power, and the Origins of Corporate Capitalism. Princeton: Princeton University Press, 2005. 
Peterson, Merrill D. Lincoln in American Memory. New York: Oxford University Press, 1994.

Peterson, Walfred H. "The Foreign Policy of the Socialist Party of America Before World War I," The Pacific Northwest Quarterly 65, no. 4 (October 1974): 176183.

Pettegrew, John. Brutes in Suits: Male Sensibility in America, 1890-1920. Baltimore: Johns Hopkins University Press, 2007.

_. "The Soldier's Faith': Turn-of-the-Century Memory of the Civil War and the Emergence of Modern American Nationalism." Journal of Contemporary History 31, no. 1 (January 1996): 49-73.

Pfaelzer, Jean. The Utopian Novel in America, 1886-1896: The Politics of Form. Pittsburgh: University of Pittsburgh Press, 1984.

Pfitzer, Gregory M. Popular History and the Literary Marketplace, 1840-1920. Amherst: University of Massachusetts Press, 2008.

Phillips, Paul T. A Kingdom on Earth: Anglo-American Social Christianity, 1880-1940. Philadelphia: Pennsylvania State University Press, 1996.

Pickus, Noah. True Faith and Allegiance: Immigration and American Civil Nationalism. Princeton: Princeton University Press, 2009.

Piott, Steven L. American Reformers, 1870-1920: Progressives in Word and Deed. Lanham, Maryland: Rowman \& Littlefield, 2006.

- Americans in Dissent: Thirteen Influential Social Critics of the Nineteenth Century. London: Lexington Books, 2014.

Pinar, William F. "The N.A.A.C.P. and the Struggle for Antilynching Legislation, 18971917." Counterpoints 163 (2001): 623-682.

Pitzer, Donald E., ed. America's Communal Utopias. Chapel Hill: University of North Carolina Press, 1997

Polgar, Paul. "Fighting Lightning with Fire: Black Boston's Battle Against 'The Birth of a Nation'." Massachusetts Historical Review 10 (2008): 84-113.

Postel, Charles. The Populist Vision. New York: Oxford University Press, 2007. 
Postell, Joseph and Johnathan O'Neill, eds. Toward an American Conservatism: Constitutional Conservatives During the Progressive Era. New York: Palgrave Macmillan, 2013.

Potter, Claire Bond. "The Problem of the Color Line: Segregation, Politics, and Historical Writing." Cultural Critique 38 (Winter 1997-1998): 65-89.

Powell, Lawrence N. New Masters: Northern Planters during the Civil War and Reconstruction. New York: Fordham University Press, 1980.

Powell, Susan. "'By This Device We Can Stir Them': The Birth of a Nation and the Origins of the Civil Rights Movement." M.A. Thesis. University of North Alabama, 2010.

Prettyman, Gib. "Gilded Age Utopias of Incorporation." Utopian Studies 12, no. 1 (2001): 19-40.

Prince, K. Stephen. Stories of the South: Race and the Reconstruction of Southern Identity, 1865-1915. Chapel Hill: University of North Carolina Press, 2014.

Quandt, Jean B. "Religion and Social Thought: The Secularization of Postmillenialism." American Quarterly 25, no. 4 (October 1973): 390-409.

Rable, George C. But There Was No Peace: The Role of Violence in the Politics of Reconstruction. Athens: University of Georgia Press, 1984.

Rader, Benjamin G. The Academic Mind and Reform: The Influence of Richard T. Ely in American Life. Lexington: University of Kentucky Press, 1966.

Railton, Ben. Contesting the Past, Reconstructing the Nation: American Literature and Culture in the Gilded Age, 1876-1893. Tuscaloosa: University of Alabama Press, 2007.

Ranney, Joseph A. In the Wake of Slavery: Civil War, Civil Rights, and the Reconstruction of Southern Law. Westport: Praeger, 2006.

Ratner-Rosenhagen, Jennifer. American Nietzsche: A History of an Icon and His Ideas. Chicago: University of Chicago Press, 2012.

Ratto, Matt and Megan Boler, eds. DIY Citizenship: Critical Making and Social Media. Boston: MIT Press, 2014.

Redding, Kent. Making Race, Making Power: North Carolina's Road to Disfranchisement. Chicago: University of Illinois Press, 2003. 
Rees, Jonathan. Industrialization and the Transformation of American Life: A Brief Introduction. New York: Routledge, 2012.

Reilly, Elizabeth, ed. Infinite Hope and Disappointment: The Story of the First Interpreters of the Fourteenth Amendment. Akron: University of Akron Press, 2011.

Reimers, David. Unwelcome Strangers: American Identity and the Turn Against Immigration. New York: Columbia University Press, 1999.

Remillard, Arthur. Southern Civil Religions: Imagining the Good Society in the PostReconstruction Era. Athens: University of Georgia Press, 2011.

Reuben, Julie A. The Making of the Modern University: Intellectual Transformation and the Marginalization of Morality. Chicago: University of Chicago Press, 1996.

- "Beyond Politics: Community Civics and the Redefinition of Citizenship in the Progressive Era." History of Education Quarterly 37, no. 4 (Winter 1997): 399420.

Richardson, Heather Cox. The Death of Reconstruction: Race, Labor, and Politics in the Post-Civil War North, 1865-1901. Cambridge: Harvard University Press, 2002.

- West From Appomattox: The Reconstruction of America After the Civil War. New Haven: Yale University Press, 2007.

Richardson, Riché. Black Masculinity and the U.S. South: From Uncle Tom to Gangsta. Athens: University of Georgia Press, 2007.

Rice, Tom. White Robes, Silver Screens: Movies and the Making of the Ku Klux Klan. Bloomington: Indiana University Press, 2015.

Rieser, Andrew C. The Chautauqua Moment: Protestants, Progressives, and the Culture of Modern Liberalism. New York: Columbia University Press, 2003.

Ring, Natalie J. The Problem South: Region, Empire, and the New Liberal State, 17701930. Athens: University of Georgia Press, 2012.

Riser, R. Volney. Defying Disfranchisement: Black Voting Rights Activism in the Jim Crow South, 1890-1908. Baton Rouge: Louisiana State University Press, 2010.

Roberts, Jon H. Darwinism and the Divine in America: Protestant Intellectuals and Organic Evolution, 1859-1900. Madison: University of Wisconsin Press, 1988. 
Roberts, Samuel K. "Kelly Miller and Thomas Dixon, Jr. on Blacks in American Civilization." Phylon 41, no. 2 (1980): 202-209.

Robinson, Cedric J. Black Marxism: The Making of the Black Radical Tradition. Chapel Hill: University of North Carolina Press, 2000.

Rodgers, Daniel. Atlantic Crossings: Social Politics in a Progressive Age. Cambridge: Harvard University Press, 1998.

Roediger, David R. The Wages of Whiteness: Race and the Making of the American Working Class. New York: Verso, 1991.

Roediger, David and Elizabeth D. Esch. The Production of Difference: Race and the Management of Labor in U.S. History. New York: Oxford University Press, 2012.

Roemer, Kenneth M. The Obsolete Necessity: America in Utopian Writings, 1888-1900. Kent: Kent State University Press, 1976.

Rogin, Michael. "The Sword Became a Flashing Vision: D.W. Griffith's The Birth of a Nation." Representations, no. 9 (Winter 1985): 150-195.

Rollins, Peter C. and John E. O'Conner, eds. Hollywood's White House: The American Presidency in Film and History. Lexington: University Press of Kentucky, 2003.

Rooney, Charles J., Jr. Dreams and Visions: A Study of American Utopias, 1865-1917. New York: Praeger, 1985.

Rosen, Hannah. Terror in the Heart of Freedom: Citizenship, Sexual Violence, and the Meaning of Race in the Postemancipation South. Chapel Hill: University of North Carolina Press, 2009.

Ross, Dorothy. The Origins of American Social Science. New York: Cambridge University Press, 1991.

Ross, William G. A Muted Fury: Populists, Progressives, and Labor Unions Confront I the Courts, 1890-1937. Princeton: Princeton University Press, 2014.

Rossinow, Doug. Visions of Progress: The Left-Liberal Tradition in America. Philadelphia: University of Pennsylvania Press, 2008.

Rove, Karl. The Triumph of William McKinley: Why the Election of 1896 Still Matters. New York: Simon \& Schuster, 2015. 
Rubin, Anne Sarah. A Shattered Nation: The Rise and Fall of the Confederacy, 18611868. Chapel Hill: University of North Carolina Press, 2005.

Rudolph, Frederick. The American College and University: A History. New York: Alfred A. Knopf, 1962.

Ruiz-Velasco, Chris. "Order Out of Chaos: Whiteness, White Supremacy, and Thomas Dixon, Jr." College Literature 34, no. 4 (Fall 2007): 148-165.

Rylance, David. "Breech Birth: The Receptions to D.W. Griffith's 'The Birth of a Nation'." Australasian Journal of American Studies 24, no. 2 (December 2005): $1-20$.

Salazar, James B. Bodies of Reform: The Rhetoric of Character in Gilded Age America. New York: New York University Press, 2010.

Salvatore, Nicholas. Eugene V. Debs: Citizen and Socialist. Chicago: University of Illinois Press, 2007.

Sanders, M. Elizabeth. Roots of Reform: Farmers, Workers, and the American State, 1877-1917. Chicago: University of Chicago Press, 1999.

Saunders, Bruce David. "Herbert Baxter Adams and the Development of American Higher Education, 1876-1901." Dissertation. University of Texas at Austin, 1975.

Schaefer, Richard T. “The Ku Klux Klan: Continuity and Change.” Phylon 32, no. 2 ( $2^{\text {nd }}$ Quarter 1971): 143-157.

Schmidt, Peter. Sitting in Darkness: New South Fiction, Education, and the Rise of Jim Crow Colonialism, 1865-1920. Jackson: University of Mississippi Press, 2008.

Schultz, Mark. The Rural Face of White Supremacy: Beyond Jim Crow. Urbana: University of Illinois Press, 2005.

Scott-Childress, Reynolds J. Race and the Production of Modern American Nationalism. New York: Garland, 1999.

Sheehan-Dean, Aaron. "The Long Civil War: A Historiography of the Consequences of the Civil War," The Virginia Magazine of History and Biography 119, no. 2 (2011): 106-153.

Sheffer, Jolie A. The Romance of Race: Incest, Miscegenation, and Multiculturalism in the United States, 1880-1930. New Brunswick: Rutgers University Press, 2012. 
Silber, Nina. The Romance of Reunion: Northerners and the South, 1865-1900. Chapel Hill: University of North Carolina Press, 1993.

Simmon, Scott. The Films of D.W. Griffith. New York: Cambridge University Press, 1993

Simmons, Christina. "Women's Power in Sex Radical Challenges to Marriage in the Early-Twentieth Century United States.” Feminist Studies 29, no. 1 (Spring 2003): 168-198.

Simonini, R.C., Jr., ed. Education in the South: Institute of Southern Culture Lectures at Longwood College, 1959. Farmville: Longwood College 1959.

Sklar, Martin. The United States as a Developing Country: Studies in U.S. History in the Progressive Era and the 1920s. New York: Cambridge University Press, 1992.

Skowronek, Stephen. Building a New American State: The Expansion of National Administrative Capacities, 1877-1920. Cambridge: Cambridge University Press, 1982.

—. "The Reassociation of Ideas and Purpose: Racism, Liberalism, and the American Political Tradition." The American Political Science Review 100, no. 3 (August 2006): 385-401.

Slap, Andrew L. The Doom of Reconstruction: The Liberal Republicans in the Civil War Era. New York: Fordham University Press, 2007.

Slide, Anthony. American Racist: the Life and Films of Thomas Dixon. Lexington: University Press of Kentucky, 2004.

Smith, Bonnie G. "Gender and the Practices of Scientific History: The Seminar and Archival Research in the Nineteenth Century." The American Historical Review 100, no. 4 (October 1995): 1150-1176.

Smith, John David. An Old Creed for the New South: Proslavery Ideology and Historiography, 1865-1918. Carbondale: Southern Illinois University Press, 2008.

Smith, John David and J. Vincent Lowery, eds. The Dunning School: Historians, Race, and the Meaning of Reconstruction. Lexington: University Press of Kentucky, 2013.

Smith, Jon and Deborah Cohn, eds. Look Away! The U.S. South in New World Studies. Durham: Duke University Press, 2004. 
Smith, Rogers. Civic Ideals: Conflicting Visions of Citizenship in U.S. History. New Haven: Yale University Press, 1997.

Smith-Rosenberg, Carroll. This Violent Empire: The Birth of an American National Identity. Chapel Hill: University of North Carolina Press, 2012.

Snay, Mitchell. Fenians, Freedman, and Southern Whites: Race and Nationality in the Era of Reconstruction. Baton Rouge: Louisiana State University Press, 2007.

Solomon, Mark. The Cry Was Unity: Communists and African Americans, 1917-1936. Jackson: University Press of Mississippi, 1998.

St. Claire, Kenneth Edson. The Administration of Justice in North Carolina During Reconstruction, 1865-1876. Columbus: Ohio State University Press, 1940.

Stears, Marc. Progressives, Pluralists, and the Problems of the State: Ideologies of Reform in the United States and Britain, 1909-1926. Oxford: Oxford University Press, 2006.

- Demanding Democracy: American Radicals in Search of a New Politics. Princeton: Princeton University Press, 2010.

Stecopoulos, Harilaos. Reconstructing the World: Southern Fictions and U.S. Imperialisms, 1898-1976. Ithaca: Cornell University Press, 2008.

— University of Iowa Press, 2011.

Steffes, Tracy Lynn. School, Society, and State: A New Education to Govern Modern America, 1890-1940. Chicago: University of Chicago Press, 2012.

Stein, Melissa N. Measuring Manhood: Race and the Science of Masculinity, 1830-1934. Minneapolis: University of Minnesota Press, 2015.

Stern, Alexandra. Eugenic Nation: Faults and Frontiers of Better Breeding in Modern America. Berkeley: University of California Press, 2005.

Stokes, Mason. The Color of Sex: Whiteness, Heterosexuality, and the Fictions of White Supremacy. Durham: Duke University Press, 2001.

Stokes, Melvyn. D.W. Griffith's The Birth of a Nation: A History of "the Most Controversial Motion Picture of All Time." New York: Oxford University Press, 2007. 
- "Race, Politics, and Censorship: D.W. Griffith's The Birth of a Nation in France, 1916-1923.” Cinema Journal 50, no. 1 (Fall 2010): 19-38.

Straub, Eberhard. Johann Gustav Droyson and the History of Prussia. Berlin: Walter de Gruyter, 2000.

Streeby, Shelley. American Sensations: Class, Empire, and the Production of Popular Culture. Berkeley: University of California Press, 2002.

Stromquist, Shelton. Reinventing “The People”: The Progressive Movement, the Class Problem, and the Origins of Modern Liberalism. Urbana: University of Illinois Press, 2006.

Suderman, Elmer. "Utopia, The Kingdom of God, and Heaven: Utopian, Social Gospel, and Gates Ajar Fiction." American Studies 31, no. 1 (Spring 1990): 91-101

Summers, Mark Wahlgren. Party Games: Getting, Keeping, and Using Power in Gilded Age Politics. Chapel Hill: University of North Carolina Press, 2004.

- The Ordeal of The Reunion: A New History of Reconstruction. Chapel Hill: University of North Carolina Press, 2014.

Summers, Martin Anthony. Manliness and its Discontents: The Black Middle Class and the Transformation of Masculinity, 1900-1930. Chapel Hill: University of North Carolina Press, 2004.

Sussman, Robert Wald. The Myth of Race: The Troubling Persistence of an Unscientific Idea. Harvard University Press, 2014.

Sutherland, Daniel E. The Confederate Carpetbaggers. Baton Rouge: Louisiana State University Press, 1988.

Sutton, Robert P. Communal Utopias and the American Experience: Secular Communities, 1824-2000. New York: Praeger, 2004.

Szasz, Ferenc Morton. The Divided Mind of Protestant America, 1880-1930. Tuscaloosa: University of Alabama Press, 1982.

Teaford, Jon C. The Rise of the States: Evolution of American State Government. Baltimore: Johns Hopkins University Press, 2002.

Taylor, Melanie Benson. Disturbing Calculations: the Economics of Identity in Postcolonial Southern Literature, 1912-2002. Athens: University of Georgia Press, 2008. 
Thelin, John R. A History of American Higher Education. Baltimore: Johns Hopkins University Press, 2004.

Thies, Clifford F. "The Success of American Communes." Southern Economic Journal 67, no. 1 (July 2000): 186-199.

Thomas, Brook. “Thomas Dixon's A Man of the People: How Lincoln Saved the Union by Cracking Down on Civil Liberties." Law and Literature 20, no. 1 (Spring 2008): 21-48.

—. "The Clansman's Race-Based Anti-Imperialist Imperialism." The Mississippi Quarterly 62, no. 1/2 (Winter 2009): 303-333.

— " "The Legal and Literary Complexities of U.S. Citizenship Around 1900." Law and Literature 22 (Summer 2010): 307-324.

—_. "Reconstructing State and Federal Jurisdiction in A Fool's Errand and The Clansman," English Language Notes 48 (Winter 2010): 71-85.

Thomas, John L. Alternative America: Henry George, Edward Bellamy, Henry Demarest Lloyd and the Adversary Tradition. New York: Belknap Press, 1983.

Tichenor, Daniel J. Dividing Lines: The Politics of Immigration Control in America. Princeton: Princeton University Press, 2002.

Tindall, George Brown. The Emergence of the New South, 1913-1945. Baton Rouge: Louisiana State University Press, 1967.

Towns, Stuart W. Enduring Legacy: Rhetoric and Ritual of the Lost Cause. Tuscaloosa: University of Alabama Press, 2010.

Townsend, Robert B. History's Babel: Scholarship, Professionalization, and the Historical Enterprise in the United States, 1880-1940. Chicago: University of Chicago Press, 2013.

Trelease, Allen W. White Terror: The Ku Klux Conspiracy and Southern Reconstruction. New York: Harper \& Row, 1971.

Tunnell, Ted. "Creating the Propaganda of History: Southern Editors and the Origins of Carpetbagger and Scalawag." Journal of Southern History 72, no. 4 (November 2006): 789-822.

Tyack, David B. and Larry Cuban. Tinkering Toward Utopia: A Century of Public School Reform. Cambridge: Harvard University Press, 1995. 
Tyrrell, Ian. "Making Nations/Making States: American Histories in the Context of Empire." The Journal of American History 86, no. 3 (December 1999): 10151044.

Upchurch, Thomas Adams. Legislating Racism: The Billion Dollar Congress and the Birth of Jim Crow. Lexington: University Press of Kentucky, 2004.

Urban, Greg, ed. Corporations and Citizenship. Philadelphia: University of Pennsylvania Press, 2014.

Usselman, Steven W. Regulating Railroad Innovation: Business, Technology, and Politics in America, 1840-1920. New York: Cambridge University Press, 2002.

Valelly, Richard M. The Two Reconstructions: The Struggle for Black Enfranchisement. Chicago: University of Chicago Press, 2004.

VanOverbeke, Marc A. The Standardization of American Schooling: Linking Secondary and Higher Education, 1870-1910. New York: Palgrave Macmillan, 2008.

Veysey, Laurence R. The Emergence of the American University. Chicago: University of Chicago Press, 1965.

Vogel, Todd. ReWriting White: Race, Class, and Cultural Capital in Nineteenth Century America. New Brunswick: Rutgers University Press, 2004.

Voss, Kim. The Making of American Exceptionalism: The Knights of Labor and Class Formation in the Nineteenth Century. Ithaca: Cornell University Press, 1994.

Wacker, Grant. "The Holy Spirit and the Spirit of the Age in American Protestantism, 1880-1910.” The Journal of American History 72, no. 1 (June 1985): 45-62.

Wade, Wyn Craig. The Fiery Cross: The Ku Klux Klan in America. New York: Simon and Schuster, 1987.

Wald, Priscilla. Constituting Americans: Cultural Anxiety and Narrative Form. Durham: Duke University Press, 1995.

Walker, Robert H. Reform in America: The Continuing Frontier. Lexington: University Press of Kentucky, 1985.

Wallace, Michele Faith. "The Good Lynching and 'The Birth of a Nation': Discourses and Aesthetics of Jim Crow." Cinema Journal 43, no. 1 (Autumn 2003): 85-104.

Wan, Amy J. Producing Good Citizens: Literacy Training in Anxious Times. Pittsburgh: University of Pittsburgh Press, 2014. 
Warner, Anja. The Transatlantic World of Higher Education: Americans at German Universities, 1776-1914. Berghahn Books, 2013.

Watson, Ritchie Devon. Normans and Saxons: Southern Race Mythology and the Intellectual History of the American Civil War. Baton Rouge: Louisiana State University Press, 2008.

Wayne, Michael. Imagining Black America. New Haven: Yale University Press, 2014.

Webb, George Ernest. The Evolution Controversy in America. Lexington: University Press of Kentucky, 1994.

Weinberger, Stephen. "The Birth of a Nation and the Making of the NAACP." Journal of American Studies 45, no. 1 (2011): 77-93.

Weir, Robert E. Beyond Labor's Veil: The Culture of the Knights of Labor. Philadelphia: Pennsylvania State University Press, 1996.

Welch, Richard E. Response to Imperialism: The United States and the PhilippineAmerican War, 1899-1902. Chapel Hill: University of North Carolina Press, 1979.

Wells, Jeremy. Romances of the White Man's Burden: Race, Empire, and the Plantation in American Literature, 1880-1936. Nashville: Vanderbilt University Press, 2011.

Wesling, Meg. Empire's Proxy: American Literature and U.S. Imperialism in the Philippines. New York: New York University Press, 2011

West, Michael Rudolph. The Education of Booker T. Washington: American Democracy and the Idea of Race Relations. New York: Columbia University Press, 2006.

White, Ronald C., Jr. and C. Howard Hopkins. The Social Gospel: Religion and Reform in Changing America. Philadelphia: Temple University Press, 1976.

Williams, R. Hal. Realigning America: McKinley, Bryan, and the Remarkable Election of 1896. Lawrence: University Press of Kansas, 2010.

Williamson, Joel. The Crucible of Race: Black-White Relations in the American South Since Emancipation. New York: Oxford University Press, 1984.

Willan, Brian. “'Cinematographic Calamity' or 'Soul-Stirring Appeal to Every Briton': Birth of a Nation in England and South Africa, 1915-1931." Journal of Southern African Studies 39, no. 3 (2013): 623-640. 
Wilmer, S.E. Theatre, Society, and the Nation: Staging American Identities. New York: Cambridge University Press, 2002.

Wilson, Charles Reagan. Baptized in Blood: The Religion of the Lost Cause, 1865-1920. Athens: University of Georgia Press, 1980.

Wish, Harvey. "Negro Education and the Progressive Movement." The Journal of Negro History 49, no. 3 (July 1964): 184-200.

Wood, Amy Louise. Lynching and Spectacle: Witnessing Racial Violence in America, 1890-1940. Chapel Hill: University of North Carolina Press, 2009.

Woodley, Jenny. Art for Equality: The NAACP's Cultural Campaign for Civil Rights. Lexington: University Press of Kentucky, 2014.

Woodward, C. Vann. Origins of the New South, 1877-1913. Baton Rouge: Louisiana State University Press, 1951.

- The Burden of Southern History. Baton Rouge: Louisiana State University Press, 1960.

Wolraich, Michael. Unreasonable Men: Theodore Roosevelt and the Republican Rebels Who Created Progressive Politics. New York: Palgrave Macmillan, 2014.

Wray, Matt. Not Quite White: White Trash and the Boundaries of Whiteness. Durham: Duke University Press, 2006.

Wright, James Zebulon. “Thomas Dixon: Mind of a Southern Apologist.” Master's Thesis. George Peabody School for Teachers, 1966.

Wright, Robert E. Corporation Nation. Philadelphia: University of Pennsylvania Press, 2014.

Wyatt-Brown, Bertram. The Shaping of Southern Culture: Honor, Grace, and War, 1760s-1890s. Chapel Hill: University of North Carolina Press, 2001.

- Hearts of Darkness: Wellsprings of a Southern Literary Tradition. Baton: Rouge: Louisiana State University Press, 2003.

Yamin, Priscilla. "The Search for Marital Order: Civic Membership and the Politics of Marriage in the Progressive Era." Polity 41, no. 1 (January 2009): 86-112.

Young, Ralph. Dissent: The History of an American Idea. New York: New York University Press, 2015. 
Zakim, Michael and Gary J. Kornblith, eds. Capitalism Takes Command: The Transformation of Nineteenth-Century America. Chicago: University of Chicago Press, 2012.

Zavodnyik, Peter. The Rise of the Federal Colossus: The Growth of Federal Power from Lincoln to F.D.R. Santa Barbara: Prager, 2011.

Ziegler-McPherson, Christina A. Americanization in the States: Immigrant Social Welfare Policy, Citizenship, and National Identity in the United States, 19081929. Gainesville: University Press of Florida, 2009.

Zipf, Karin L. “'The Whites Shall Rule the Land or Die': Gender, Race, and Class in North Carolina Reconstruction Politics." The Journal of Southern History 65, no. 3 (August 1999): 499-534.

Zolberg, Aristide R. A Nation By Design: Immigration Policy in the Fashioning of America. Cambridge: Harvard University Press, 2009.

Zuczek, Richard. "The Federal Government's Attack on the Ku Klux Klan: A Reassessment." The South Carolina Historical Magazine 97, no. 1 (January 1996): 47-64.

Zunz, Olivier. Making America Corporate, 1870-1920. Chicago: University of Chicago Press, 1992.

\section{$\underline{\text { Primary Sources }}$}

Adams, Herbert Baxter. The Study of History in American Colleges and Universities. Washington, D.C.: Government Printing Office, 1887.

- The Study of History in American Colleges and Universities. Washington, D.C.: Government Printing Office, 1887.

Alexander, Archibald. The Evidences of the Christian Religion. Pittsburg: J.I. Kay \& Co., 1879.

Bellamy, Edward. The Programme of the Nationalists. Philadelphia: Bureau of Nationalist Literature, 1894.

—. Looking Backward: 2000-1887. New York: Ticknor and Company, 1887. 
Blaine, James G. Twenty Years of Congress: From Lincoln to Garfield, with a Review of Events Which Led to the Political Revolution of 1860, 2 vols. Norwich, Connecticut: Henry Bill Publishing, 1884 and 1893.

Butler, Joseph Bishop. Analogy of Religion, Natural and Revealed, to the Constitution and Course of Nature. New York: Harper \& Brothers, 1860.

Catalogues of Wake Forest College, Forty-Fifth Session, 1879-80, 5-7; Cyclopedia of Eminent and Representative Men of the Carolinas of the Nineteenth Century, Vol. II. Madison, Wisconsin: Brantor Fuller, 1892.

Catalogues of Wake Forest College, Forty-Sixth Session, 1879-81. Raleigh: Edwards, Broughton \& Co., 1880.

Demolins, Edmond, Anglo-Saxon Superiority: To What it is Due. Translated by Louis Bert Lavigne. New York: R.F. Fenno \& Company, 1898.

Dixon, Helen C.A. A.C. Dixon: A Romance of Preaching. New York: G.P. Putnam's Sons, 1931.

Dunning, William A. Reconstruction, Political and Economic, 1865-1877. New York: Harper \& Brothers, 1907.

Ely, Richard T. The Labor Movement in America. New York: Thomas Y. Crowell \& Co., 1886.

_. "Economic Theory and Labor Legislation." American Economic Association Quarterly 9, no. 1 (April 1908): 124-153.

—. Ground Under Our Feet: An Autobiography. New York: Macmillan, 1938.

George, Henry. Progress and Poverty: An Inquiry into the Cause of Industrial Depressions and of Increase of Want with Increase of Wealth the Remedy. New York: J.W. Lovell, 1879.

Herbert, Hilary A., ed. Why the Solid South? Or, Reconstruction and Its Results. Baltimore: R.H. Woodward, 1890

Hooker, Worthington. Hooker's New Physiology: Designed as a Textbook for Institutions of Learning. New York: Sheldon and Co., 1874.

Johns Hopkins University Circulars 3, no. 27 (November 1883). 
Journal of the House of Representatives of the General Assembly of the State of North Carolina at the Session of 1885. Raleigh: Ashe \& Gatling, State Printers and Binder, 1885.

Miller, Kelly. As to the Leopard's Spots: An Open Letter to Thomas Dixon, Jr. Washington, D.C.: Hayworth Publishing House, 1905.

Ogden, Robert C. "The Conference for Education in the South." Annals of the American Academy of Political and Social Science (September 1903): 27-35.

Peabody, Andrew P. A Manual of Moral Philosophy: Designed for Colleges and High Schools. New York: A.S. Barnes and Company, 1873.

Pike, James Shepard. The Prostrate State: South Carolina Under Negro Government. New York: D. Appleton, 1874.

Pollard, Edward A. The Lost Cause: a New Southern History of the War of the Confederates: Comprising a Full and Authentic Account of the Rise and Progress of the Late Southern Confederacy - the Campaigns, Battles, Incidents, and Adventures of the Most Gigantic Struggle of the World's History. New York: E.B. Treat, 1866.

Proceedings of the Conference for Education in the South: The Sixth Session. The Committee on Publication: New York City, 1903.

Proceedings of the Conference for Education in the South: The Seventh Session. The Committee on Publication: New York, 1906.

Rhodes, James Ford. History of the United States from the Compromise of 1850 to the Final Restoration of Home Rule at the South in 1877, 9 vols. New York: Macmillan, 1920.

The Wake Forest Student, 1882-1883, Vol. II. Raleigh: Edwards, Broughton \& Co., 1883.

Upham, Thomas C. Elements of Mental Philosophy: Abridged and Designed as Textbook for Academies and High Schools. New York: Harper \& Brothers, 1857.

Wilson, Henry. History of the Rise and Fall of the Slave Power in America, 3 vols. Boston: James R. Osgood, 1872-1877. 
Appendix: The Selected Works of Thomas Dixon, $\mathrm{Jr}^{983}$

\section{Non-Fiction}

Living Problems in Religion and Social Science. New York: Charles T. Dillingham, 1889.

What is Religion?: An Outline of Vital Ritualism: Four Sermons Preached in Association Hall, New York, December 1890. New York: Scott Publishing Co., 1891.

Dixon on Ingersoll: Ten Discourses, Delivered in Association Hall, New York. New York: John B. Alden, 1892.

The Failure of Protestantism in New York and Its Causes. New York: Victor O.A. Strauss, 1896.

Dixon's Sermons: Delivered in the Grand Opera House, New York, 1898-1899. New York: F.L. Bussey, 1899.

The Rising South: An Address. Raleigh, N.C.: H.S. Storr, Printers, 1926.

H.M. Daugherty and Thomas Dixon. The Inside Story of the Harding Tragedy. New York: the Churchill Company, 1932.

$\underline{\text { Novels and Autobiographical Works }}$

The Leopard's Spots: A Romance of the White Man's Burden, 1865-1900. New York: Doubleday, Page, 1902.

The One Woman: A Story of Modern Utopia. New York: Doubleday, Page, 1903.

The Life Worth Living: A Personal Experience. New York: Doubleday, Page, 1905.

The Clansman: An Historical Romance of the Ku Klux Klan. New York: Doubleday, Page, 1905.

The Traitor: A Story of the Fall of the Invisible Empire. New York: Doubleday, Page, 1907.

\footnotetext{
983 This appendix has been compiled using the information in: Gillespie and Hall, eds., Thomas Dixon, Jr., and the Birth of Modern America (2006) and in Slide, American Racist (2004).
} 
Comrades: A Story of Social Adventure in California. New York: Grosset and Dunlap, 1909.

The Root of Evil: A Novel. Garden City, NY: Doubleday, Page, 1911.

The Sins of the Father: A Romance of the South. New York: D. Appleton, 1912.

The Southerner: A Romance of the Real Lincoln. New York: D. Appleton, 1913.

The Victim: A Romance of the Real Jefferson Davis. New York: D. Appleton, 1914.

The Foolish Virgin: A Romance of Today. New York: D. Appleton, 1915.

The Fall of a Nation: A Sequel to The Birth of a Nation. New York: D. Appleton, 1916.

The Way of a Man: A Story of the New Woman. New York: D. Appleton, 1919.

The Red Dawn: A Drama of Revolution. New York: no publisher, 1919.

A Man of the People: A Drama of Abraham Lincoln. New York: D. Appleton, 1920.

The Man in Gray: A Romance of North and South. New York: D. Appleton, 1921.

The Black Hood. New York: D. Appleton, 1924.

The Love Complex. New York: Boni and Liveright, 1925.

The Hope of the World: A Story of the Coming War. New York: self-published, 1925.

The Torch: A Story of the Paranoic Who Caused a Great War. New York: selfPublished, 1927.

The Sun Virgin. New York: H. Liveright, 1929.

Companions. New York: Otis Publishing Company, 1931.

A Dreamer in Portugal: The Story of Bernarr McFadden's Mission to Continental Europe. New York: Covici, Friede, 1934.

The Flaming Sword. Atlanta: Monarch, 1939.

\section{$\underline{\text { Films and Screenplays }}$}

The Birth of a Nation (1915). Screenplay by D.W. Griffith and Frank E. Woods, based on The Clansman and the play of the same name by Thomas Dixon, Jr. 
The Fall of a Nation (1916). Directed by and screenplay by Thomas Dixon, Jr.

The Foolish Virgin (1916). Based on the novel by Thomas Dixon, Jr.

The One Woman (1918). Based on the novel by Thomas Dixon, Jr.

Bolshevism on Trial (1919). Based on the novel Comrades by Thomas Dixon, Jr.

Wingtoy (1921). Screenplay by Thomas Dixon, Jr.

Where Men are Men (1921). Screenplay by Thomas Dixon, Jr.

Bring Him In (1921). Screenplay by Thomas Dixon, Jr., based on a story by H.H. Van Loan.

Thelma (1922). Screenplay by Thomas Dixon, based on the novel by Marie Corelli.

The Mark of the Beast (1923). Directed by and screenplay by Thomas Dixon, Jr. Thomas Dixon Productions.

The Foolish Virgin (1924). Based on the novel by Thomas Dixon, Jr.

The Painted Lady (1924). Screenplay by Thomas Dixon, Jr., based on the Saturday Evening Post story by Larry Evans.

The Great Diamond Mystery (1924). Screenplay by Thomas Dixon, Jr., based on a Story by Shannon Fife.

The Brass Bowl (1924). Screenplay by Thomas Dixon, Jr., based on the novel by Louis Joseph Vance.

Champion of Lost Causes (1925). Screenplay by Thomas Dixon, Jr., based on the Flynn's Magazine story by Max Brand.

The Trail Rider (1925). Screenplay by Thomas Dixon, Jr., based on the novel by George Washington Ogden.

The Gentle Cyclone (1926). Screenplay by Thomas Dixon, Jr., based on the Western Story Magazine story "Peg Leg and Kidnapper” by Frank R. Buckley.

Nation Aflame (1937). Original story by Thomas Dixon, Jr., in collaboration with Oliver Drake and Rex Hale. 
VITA

\section{TIFFANY WEST}

Born, Jacksonville, Florida

2008

B.A., History

Jacksonville University

Jacksonville, Florida

2010-2012

Graduate Teaching Assistant

Department of History

Florida International University

Miami, Florida

2012

M.A., History

Florida International University

Miami, Florida

2012-2014

Graduate Teaching Assistant

Florida Teacher Quality Grant Program

Florida International University

Miami, Florida

2014-2016

Doctoral Candidate

Florida International University

Miami, Florida

Graduate Teaching Assistant

Department of History

Florida International University

Miami, Florida

\section{PRESENTATIONS AND PUBLICATIONS}

2016 "Old Hickory' and the Sunshine State" Accepted for inclusion in Jackson in Florida, The Early Years Edited by James G. Cusick and Sherry Johnson Florida Historical Society Press, publication date in late 2016

2015 “'Klan is Denounced By The Clansman': Thomas Dixon, Jr. and Anti-Klan Sentiment"

Department of History Graduate Student Association Annual Conference Miami, FL 
2014 "Jingo Ministers and Armed Intervention: Late-Nineteenth Century Political Debates in the Pulpit"

Florida Conference of Historians, Annual Meeting

St. Augustine, FL

2014 "'Brothers in Flesh, Not Theology': Protestant Schisms in Late-Nineteenth Century City," The Atlantic Millennium: An Academic Journal on Atlantic Civilization 13 (2014-2015): 30-43.

2012 "The Social Gospel of Thomas Dixon, Jr."

Department of History Graduate Student Association Annual Conference Miami, FL

2010 "The Taboo of Tattoos" Florida Conference of Historians, Annual Meeting Wakulla Springs, FL

2010 "The Taboo of Tattoos," Jacksonville University Journal for Research Across the Disciplines (Spring 2010). 